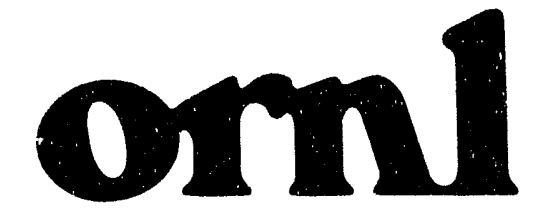

OAK RIDGE NATIONAL LABORATORY

MARTIN MAQRUETRA
Energy Efficiency and Renewable Energy Program

\author{
Bibliography
}

1993 Edition

K. H. Vaughan 
ORNL/CON-368

\title{
ENERGY EFFICIENCY AND RENEWABLE ENERGY PROGRAM
}

\author{
BIBLIOGRAPHY
}

1993 Edition

Kathi H. Vaughan

Date Published—June 1993

Prepared by the

Oak Ridge National Laboratory

Oak Ridge, Tennessee 37831

managed by

MARTIN MARIETTA ENERGY SYSTEMS, INC.

for the

U.S. DEPARTMENT OF ENERGY

under contract DE-AC05-84OR21400

MASTER

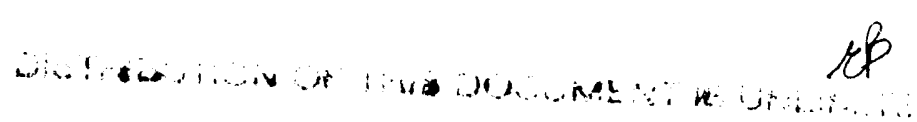




\section{Contents}

Page

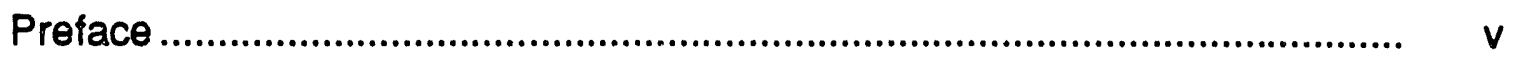

Analysis and Evaluation ............................................................... 1

Building Equipment Research............................................................... 11

Building Thermal Envelope Systems and Materials ................................. 21

District Heating ......................................................................................... 33

Residential and Commercial Conservation Program ................................ $\quad 35$

Weatherization Assistance Program .................................................... $\quad 37$

Existing Buildings Research Program.................................................. 39

Ceramic Technology Project .................................................................... 45

Alternative Fuels and Propulsion Technology....................................... 67

Microemulsion Fuels ........................................................................ $\quad 75$

Industrial Chemical Heat Pumps ............................................................ 77

Materials For Advanced Industrial Heat Exchangers ................................ 79

Advanced Industrial Materials .................................................................. 81

Tribology ......................................................................................... 89

Energy-Related Inventions Program .................................................... 93

Electric Energy Systems ....................................................................... 95

Superconducting Technology Program for Electic Energy Systems............. 105

Thermal Energy Storage ..................................................................... 111

Biofuels Feedstock Development........................................................ 115

Biotechnology................................................................................... 133

Continuous Chromatography In Multicomponent Separations..................... 135

Sensors For Electrolytic Cells ........................................................ 137

Hydropower Environmental Mitigation ................................................... 139

Environmental Control Technology ....................................................... 141

Continuous Fiber Ceramic Composite Technology.................................. 143 


\section{PREFACE}

The Bibliography contains listings of publicly available reports, journal articles, and published conference papers sponsored by the DOE Office of Energy Efficiency and Renewable Energy and published between 1987 and mid-1993. Information on documents published prior to 1987 can be obtained from Kathi Vaughan at the address given below.

Most of the documents in the Bibliography are available from Oak Ridge National Laboratory. Single copies may be requested by contacting Kathi Vaughan. Items may also be purchased from the National Technical Information Service (address given below), or obtained directly from the publisher, libraries, or other information service.

Kathi $H$. Vaughan

Conservation and Renewable Energy Program

Oak Ridge National !-aboratory

P. O. Box 2008

Oak Ridge TN 37831-6188

Facsimile 615/576-7572

Voice 615/574-5204

National Technical Information Service

U.S. Department of Commerce

5285 Port Royal Road

Springfield VA 22151 


\section{ANALYSIS AND EVALUATION}

1

\section{Regulators}

A Good Integrated Resource Plan: Guldellnes for Electric UtIlitles and

ORNLCON-354 (December 1992)

E. Hirst. Oak Ridge National Laboratory, Oak Ridge, Tenn.

2

Electric-UtIllty DSM Programs: 1990 Data and Forecasts to 2000

ORNL-CON-347 (June 1992)

E. Hirst. Oak Ridge National Laboratory, Oak Ridge, Tenn.

Effects of UtIllty DSM Programs on Risk

ORNL/CON-346 (May 1992)

E. Hirst. Oak Ridge National Laboratory, Oak Ridge, Tenn.

Transportation Energy Data Book: Edition 12

OFNL-6710 (Edition 12 of ORNL-5198) (March 1992)

S. C. Davis. Oak Ridge National Laboratory, Oak Ridge, Tenn.

M. D. Morris. University of Tennessee, Knoxville, Tenn.

The Demand-Side Management Program Development Process-A Utility Perspectlve

ORNUCON-345 (March 1992)

A. K. Wolfe. Oak Ridge National Laboratory, Oak Ridge, Tenn.

N. E. Yourstone. Consultant to Oak Ridge National Laboratory, Oak Ridge, Tenn.

From DSM Technologies to DSM Programs: Issues In Demand-Side Planning for Electric Utilities

Energy 17(2), pp. 151-60 (February 1992)

L. J. Hill, E. Hirst, M. Schweitzer. Oak Ridge Nationa Laboratory, Oak Ridge, Tenn.

Publlc Involvement In Integrated Resource Planning: A Study of DemandSide Management Collaboratives

ORNLCON-344 (February 1992)

J. Raab. Consultant to Oak Ridge National Laboratony, Oak Ridge, Tenn.

M. Schweitzer. Oak Ridge National Laboratory, Oak Fidge, Tenn.

The Role of Evaluation When Electrlc UtIlities Get Financlal Incentives for Their DSM Programs

Evaluation Review 16(1), pp. 93-107 (February 199?)

E. Hirst. Oak Ridge National Laboratory, Oak Ridge, Tenn.

\section{Making Energy Efficlency Happen}

pp. 205-21, Technologies for a Greenhouse-Constrained Society, ed. M. A. Kuliasha, A. Zucker, and K. J. Ballew (Chelsea, Mich.: Lewis Publizhers, Inc., 1992)

E. Hirst. Oak Ridge National Laboratory, Jak Ridge, Tenn.

10 Data and Analysis Needed to Prepare an Electric-Utility Integrated Resource Plan

Proceedings of Clean Air Workshop, Columbus, Ohio, May 7-8, 1992 (National Regulatory Research Institute, 1992)

E. Hirst. Oak Ridge National Laboratory, Oak Ridge, Tenn.

11 Definitions and Tradeoffs: Cost-Effectlveness of UtIlity DSM Programs

Proceedings ACEEE 1992 Summer Study on Energy Efficiency in Buildings , pp. 8.898.97 (Washington, D.C.: American Council for an Energy-Efficient Economy, 1992)

E. Hirst. Oak Ridge National Laboratory, Oak Ridge, Tenn. 
12 Coming to Terms with DSM

Proceedings ACEEE 1992 Summer Study on Energy Efficiency in Buildings, pp. 7.2037.205 (Washington, D.C.: American Council for an Energy-Efficient Economy, 1992)

E. Hirst. Oak Ridge National Laboratory, Oak Ridge, Tenn.

C. Sabo. Barakat and Chamberlin, Inc., Washington, D.C

13 The Context and Organization of Demand-Side Management Collaboratlves: An Overview

Proceedings ACEEE 1992 Summer Study on Energy Efficiency in Buildings, pp. 8.1418.149 (Washington, D.C.: American Council for an Energy-Efficient Economy, 1992)

M. Schweitzer. Oak Ridge National Laboratory, Oak Ridge, Tenn.

J. Raab. Raab Associates, Boston, Mass.

14 The Rellablilty of Residential Energy Conservation Resources

Proceedings ACEEE 1992 Summer Study on Energy Efficiency in Buildings, pp. 7.2677.275 (Washington, D.C.: American Council for an Energy-Etficient Economy, 1992)

M. A. Brown, D. L. White. Oak Ridge National Laboratory, Oak Ridge, Tenn.

15 Handbook of Evaluatlon of Utility DSM Programs

ORNU/CON-336 (December 1991)

B. H. Bronfman. Bronfman \& Associates, Portland, Ore.

G. L. Fitzpatrick. Applied Energy Group, Inc., Woodbury, N.Y.

E. G. Hicks. New England Power Service Company, Westborough, Mass.

E. Hirst, J. H. Reed. Oak Ridge National Laboratory, Oak Ridge, Tenn.

M. G. Hottman, H. Michaels, A. Schon. XENERGY, Burlington, Mass.

K. Keating. Bonneville Power Administration, Portland, Ore.

S. Nadel. American Council for an Energy-Efticient Economy, Washington, D. C.

J.S. Peters. Barakat \& Chamberlin, Inc., Portland, Ore.

W. Saxonis. New York State Energy Office, Albany, N.Y.

D. M. Violette. RCG/Hagler, Bailly, Inc., Boulder, Colo.

16 Comparison of Methods to Integrate DSM and Supply Resources In Electrlc-Utillty Planning

ORNLCON-341 (December 1991)

L. J. Hill. Oak Ridge National Laboratory, Oak Ridge, Tenn.

17 The Effects of Utility DSM Programs on Electriclty Costs and Prices ORNL/CON-340 (November 1991)

E. Hirst. Oak Ridge National Laboratory, Oak Ridge, Tenn.

18 Electric-Utility DSM Programs: Terminology and Reporting Formats ORNL/CON-337 (October 1991)

E. Hirst. Oak Ridge National Laboratory, Oak Ridge, Tenn.

C. Sabo. Barakat \& Chamberlin, Inc., Washington, D. C.

19 Light-Duty Vehicle Summary: First Six Months of Model Year 1991 ORNL-6672/S1 (August 1991)

P. S. Hu. Oak Ridge National Laboratory, Oak Ridge, Tenn.

20 Improving Energy Efficlency in the USA: The Federal Role

Energy Policy, pp. 567-77 (July/August 1991)

E. Hirst. Oak Ridge National Laboratory, Oak Ridge, Tenn.

21 Highway Vehicle MPG and Market Shares Report: Model Vear 1992 ORNL-6672 (April 1991)

L. S. Williams. University of Tennessee, Knoxville, Tenn.

P. S. Hu. Oak Ridge National Laboratory, Oak Ridge, Tenn. 
22 Dlamond: A Model of Incremental Decision Making for Resource Acquisition by Electric Utilities

ORNLCON-315 (February 1991)

M. B. Gettings, E. Hirst. Oak Ridge National Laboratory, Oak Ridge, Tenn.

E. Yourstone. Consultant to Oak Ridge National Laboratory, Oak Ridge, Tenn.

23 Demand-Side Management and Integrated Resource Planning: Findings From a Survey of 24 Electrlc Utilities

ORNLCON-314 (February 1991)

M. Schweitzer, E. Hirst, L. J. Hill. Oak Ridge National Laboratory, Oak Ridge, Tenn.

24 Transportation Energy Data Book: Edition 11

ORNL-6649 (Edition 11 of ORNL-5198) (January 1991)

S. C. Davis, P. S. Hu. Oak Ridge National Laboratory, Oak Ridge, Tenn.

25 Integrating Demand-SIde Management Programs Into the Resource Plans of U.S. Electric Utillties

ORNL/CON-311 (January 1991)

L. J. Hill, E. Hirst, M. Schweitzer. Oak Ridge National Laboratory, Oak Ridge, Tenn.

26 Possible Effects of Electric-Utility DSM Programs, 1990 to 2010 ORNL/CON-312 (January 1991)

E. Hirst. Oak Ridge National Laboratory, Oak Ridge, Tenn.

27 Commerclallzing Government-Sponsored Computer Software

Advances in the Implementation and Impact of Computer Systems, ed. M. Fleisher and J. Morrell, pp. 263-75 (Greenwich, Conn.: JAI Press, 1991)

R. K. Goel, M. A. Brown. Oak Ridge National Laboratory, Oak Ridge, Tenn.

28 Evaluating Deinand-Side Management Programs

Electric Perspectives 14(6), pp. 24-30 (November/December 1990)

E. Hirst. Oak Ridge National Laboratory, Oak Ridge, Tenn.

29 Balancing the Scales: Data on Electriclty Supply and Demand Resources ORNL/CON-306 (September 1990)

E. Hirst. Oak Ridge National Laboratory, Oak Ridge, Tenn.

30 Energy Efficlency In Nonprofit Agencles: Creating Effective Program Models

ORNLTM-11602 (August 1990)

M. A. Brown, D. L. White. Oak Ridge National Laboratory, Oak Ridge, Tenn.

B. Prindle. Alliance to Save Energy, Washington, D. C.

M. I. Scherr. United Way of America, Alexandria, Va.

31 Electricity, Getting More With Less

Technology Review 93(5), pp. 32-40 (July 1990)

E. Hirst. Oak Ridge National Laboratory, Oak Ridge, Tenn.

32 Closing The Efflciency Gap: Barrlers to Improving Energy Efficiency Resources, Conservation and Recycling 3, pp. 276-81 (June 1990)

M. A. Brown, E. Hirst. Oak Ridge National Laboratory, Oak Ridge, Tenn.

33 Demand-Side Data Needs for Least-Cost Utility Planning

Energy 15(5), pp. 403-12 (May 1990)

E. Hirst. Oak Ridge National Laboratory, Oak Ridge, Tenn.

C. Goldman. Lawrence Berkeley Laboratory, Berkeley, Calif. 
34 Balancling the Scales: Toward Parlty In Electric Supply and Demand Data The Electricity Joumai 3(4), pp. 28-33 (May 1990)

E. A. Hirst. Oak Ridge National Laboratory, Oak Ridge, Tenn.

35 Key Issues In Electric Utillty Integrated Resource Planning: Findings from a Nationwlde Study ORNL/CON-300 (April 1990)

M. Schweitzer, E. Hirst. Oak Ridge National Laboratory, Oak Ridge, Tenn.

E. Yourstone. Consultant to Oak Ridge National Laboratory, Oak Ridge, Tenn.

36 Progress and Potential In Evaluating Energy-Efficiency Programs Evaluation Review 14(2), pp. 192-205 (April 1990)

E. Hirst. Oak Ridge National Laboratory, Oak Ridge, Tenn.

37 The Market Penetration of Energy-Efficlency Programs ORNLCON-299 (April 1990)

L. Berry. Oak Ridge National Laboratory, Oak Ridge, Tenn.

38 Light-Duty Vehicle MPG and Market Shares Report: Model Year 1989 ORNL-6626 (April 1990)

L. S. Williams. University of Tennessee, Knoxville, Tenn.

P. S. Hu. Oak Ridge National Laboratory, Oak Ridge, Tenn.

39 Why The Federal Government Should Help Improve U.S. Energy Efflclency

Ambio, A Journal of the Human Environment XIX(2), pp. 96-98 (April 1990)

E. Hirst. Oak Ridge National Laboratory, Oak Ridge, Tenn.

40 Demonstrations as a Pollcy Instrument with Energy Technology Examples Knowledge: Creation, Diffusion, and Utilization 11(3): pp. 219-36 (March 1990)

S. M. Macey. Southwest Texas State University, San Marcos, Texas

M. A. Brown. Oak Ridge National Laboratory, Oak Ridge, Tenn.

41 Guldellnes for a "Good" Integrated Resource Plan

Public Utilities Fortnightly 125(7), pp. 18-24 (March 1990)

E. Hirst. Oak Ridge National Laboratory, Oak Ridge, Tenn.

42 Assessing Integrated Resource Plans Prepared by Electric UtIlities ORNL/CON-298 (February 1990)

E. Hirst, M. Schweitzer. Oak Ridge National Laboratory, Oak Ridge, Tenn.

E. Yourstone. Consultant to Oak Ridge National Laboratory, Oak Ridge, Tenn.

J. Eto. Lawrence Berkeley Laboratory, Berkeley, Calif.

43 Energy Efficiency: How Far Can We Go?

ORNL/TM-11441 (January 1990)

R. S. Carlsmith. Oak Ridge National Laboratory, Oak Ridge, Tenn.

W. U. Chandler. Battelle-Pacific Northwest Laboratories, Washington, D.C.

J. E. McMahon. Lawrence Berkeley Laboratory, Berkeley, Calif.

D. J. Santini. Argonne National Laboratory, Argonne, III. 
44 The Technology Transfer Process: Background for the U.S. National Energy Strategy

PNL-SA-17482* (Richland, Wash.: Pacific Northwest Laboratory, January 1990)

D. E. Deonigi, N. L. Moore, S. A. Smith, R. L. Watts. Pacific Northwest Laboratory,

Richland, Wash.

M. A. Brown. Oak Ridge National Laboratory, Oak Ridge, Tenn.

R. J. Noun. Solar Energy Research Institute, Golden, Colo.

45 Flexiblilty Beneflis of Demand-Slde Programs In Utillty Planning

The Energy Journal 11(1), pp. 151-65 (1990)

E. Hirst. Oak Ridge National Laboratory, Oak Ridge, Tenn.

46 Technology-Transfer Strategles of DOE's Conservation Programs Journal of Technology Transfer 15(1), pp. 33-40 (1990)

M. A. Brown. Oak Ridge National Laboratory, Oak Ridge, Tenn.

C. H. Major. U.S. Department of Energy, Office of Conservation and Renewable Energy, Washington, D. C.

47 Electrlc.UtIlity Resource Planning and Decision Making: The Importance of Uncertalnty

Risk Analysis 10(1), pp. 137-46 (1990)

E. Hirst, M. Schweitzer. Oak Ridge National Laboratory, Oak Ridge, Tenn.

48 Data Requirements for UtIlity Integrated Resource Planning

Energy Systems \& Policy 12(4), pp. 219-31 (December 1989)

E. Hirst. Oak Ridge National Laboratory, Oak Ridge, Tenn.

49 Conservation Programs Can Cut Load-Growth Uncertainty for Electric Utillities

Technological Forecasting and Social Change 36(4), pp. 415-24 (December 1989)

E. Hirst. Oak Ridge National Laboratory, Oak Ridge, Tenn.

50 The Adminlstrative Costs of Energy Conservation Programs

ORNL/CON-294 (November 1989)

L. Berry. Oak Ridge National Laboratory, Oak Ridge, Tenn.

51 Comparison of EIA Data Collections: Electricity Supply and Demand ORNL/M-998 (October 1989)

E. Hirst. Oak Ridge National Laboratory, Oak Ridge, Tenn.

52 Federal Roles to Reallze National Energy-Efficiency Opportunities in the $1990 \mathrm{~s}$

ORNL/CON-290 (October 1989)

E. Hirst. Oak Ridge National Laboratory, Oak Ridge, Tenn.

53 Comparing Bullding Energy Analysls Software

Home Energy 6(5), pp. 13-18 (September/October 1989)

P. Weiss. Consultant to Oak Ridge National Laboratory, Oak Ridge, Tenn.

M. A. Brown. Oak Ridge National Laboratory, Oak Ridge, Tenn.

54 Transportation Energy Data Book: Edition 10

ORNL-6565 (edition 10 of ORNL-5198) (September 1989)

S. C. Davis. University of Tennessee, Knoxville, Tenn.

D. B. Shonka. Shonka Research Associates, Inc., Marietta, Ga.

G. J. Anderson-Batiste, P. S. Hu. Oak Ridge National Laboratory, Oak Ridge, Tenn.

*Available from Pacific Northwest Laboratory, Post Office Box 999, Richland, Washington 99352. 
55 Energy Use and Consumer Dissimilarity in Multifamlly Residential Conservation

Proceedings of the National Energy Program Evaluation Conference, Chicago, August 23-25, 1989, pp. 219-24 (Argonne, III.: Argonne National Laboratory, August 1989)

D. L. White. Oak Ridge National Laboratory, Oak Ridge, Tenn.

56 Recent Accomplishments of the U.S. Department of Energy's Least-Cost UtIIlty Planning Program

ORNL/CON-288 (August 1989)

L. Berry, E. Hirst. Oak Ridge National Laboratory, Oak Ridge, Tenn.

57 Light-Duty Vehicle Summary: Model Year 1976 to the First Half of Model Year 1989

ORNL/M-916 (August 1989)

L. S. Williams. University of Tennessee, Knoxville, Tenn.

P. S. Hu. Oak Ridge National Laboratory, Oak Ridge, Tenn.

58 Electric-UtIlity Energy-Efficlency and Load-Management Programs:

Resources for the 1990s

ORNL/CON-285 (June 1989)

E. Hirst. Oak Ridge National Laboratory, Oak Ridge, Tenn.

59 Least-Cost Planning In the UtIlity Sector: Progress and Challenges.

Volume 2: Technical Appendix

LBL-27131* (June 1989)

C. Goldman, F. Krause, eds. Lawrence Berkeley Laboratory, Berkeley, Calif.

E. Hirst, od. Oak Ridge National Laboratory, Oak Ridge, Tenn.

60 Least-Cost Planning in the UtIIIty Sector: Progress and Challenges

ORNL/CON-284 (May 1989)

C. Goldman, F. Krause, eds. Lawrence Berkeley Laboratory, Berkeley, Calif.

E. Hirst, ed. Oak Ridge National Laboratory, Oak Ridge, Tenn.

61 Light-Duty Vehicle MPG and Market Shares Report: Model Year 1988 ORNL-6549 (April 1989)

P. S. Hu. Oak Ridge National Laboratory, Oak Ridge, Tenn.

L. S. Williams, D. J. Beal. University of Tennessee, Knoxville, Tenn.

62 Benefits and Costs of Small, Short-Lead-TIme Power Plants and DemandSide Programs In an Era of Load-Growth Uncertainty ORNL/CON-278 (March 1989)

E. A. Hirst. Oak Ridge National Laboratory, Oak Ridge, Tenn.

63 Recent Publications of DOE's Office of Bulldings and Community Systems ORNLCON-276 (February 1989)

M. A. Brown. Oak Ridge National Laboratory, Oak Ridge, Tenn.

J. Hayes. Applied Management Sciences, Oak Ridge, Tenn.

64 Integrated Resource Planning at Electric UtIlitles: The Planning Process

Evaluation and Program Planning 12, pp. 213-23 (1989)

E. Hirst. Oak Ridge National Laboratory, Oak Ridge, Tenn.

\footnotetext{
"Available from the University of Califomia, Lawrence Berkeley Laboratory, One Cyclotron Road,
} Berkeley, California 94720. 
65 Technology Transfer Strategles of the U.S. Department of Energy's Conservation Program ORNLCON-277 (December 1988)

M. A. Brown. Oak Ridge National Laboratory, Oak Ridge, Tenn.

66 Uncertainty In Long-Term Resource Planning for Electrlc Utilities ORNL/CON-272 (December 1988)

E. Hirst, M. Schweitzer. Oak Ridge National Laboratory, Oak Ridge, Tenn.

67 Gas Furnace Purchases: A Study of Consumer Decision Making and Conservation Investments ORNLTM-10727 (October 1988)

R. A. Cantor, D. A. Trumble. Oak Ridge National Laboratory, Oak Ridge, Tenn.

68 Technical Accomplishments of DOE's Offlce of Transportation Systems ORNL/CON-267 (September 1988)

S. A. Snell. Hagler, Bailly \& Co., Inc., Washington, D.C.

M. A. Brown, S. C. Davis. Oak Ridge National Laboratory, Oak Ridge, Tenn.

69 Effects of Energy-Efficlency Programs on Load-Growth Uncertainty for Elecirlc UtIIIties

ORNL/CON-260 (August 1988)

E. A. Hirst. Oak Ridge National Laboratory, Oak Ridge, Tenn.

70 Light-Duty Vehicle MPG and Market Shares Report: First Six Months of Model Year 1988 ORNL-6496 (August 1988)

P. S. Hu. Oak Ridge National Laboratory, Oak Ridge, Tenn.

L. S. Williams. University of Tennessee, Knoxville, Tenn.

71 Modelling Operating Welght and Axle Welght Dlstrlbutlons for Highway Vehicles

ORNL-6437 (July 1988)

D. L. Greene. Oak Ridge National Laboratory, Oak Ridge, Tenn.

J.-C. Liang. Rensselaer Polytechnic Institute, Troy, N.Y.

72 Technology Transfer for DOE's Office of Transportation Systems:

Assessment and Strategles

ORNLCON-244 (April 1988)

S. A. Snell. University of Tennessee, Knoxville, Tenn.

M. A. Brown. Oak Ridge National Laboratory, Oak Ridge, Tenn.

A. M. Zerega. U. S. Department of Energy, Washington, D. C.

73 Weatherizing Homes in Portland: An Evaluation of a Community-Based Partnership Residential Conservation Pllot Program

ORNLSUb/85-06613/1 (February 1988)

S. J. Morgan. Technical Development Corp., Boston, Mass.

74 Marglnal-Cost-of-Service Analysis: A Powerful Marketing Tool for Electric UtIIItles

ORNi/CON-251 (February 1988)

E. Hirst. Oak Ridge National Laboratory, Oak Ridge, Tenn. 
75 Developing an Integrated Planning Process: An Electrlc Uillity Case Study

ORNL/CON-247 (January 1988)

E. A. Hirst. Oak Ridge National Laboratory, Oak Ridge, Tenn.

C. Knutsen. Puget Sound Power and Light Co., Bellevue, Wash.

76 Creating Vlable UtIlity Conservation/Load Management Programs Energy 13(2), pp. 33-44 (January 1988)

E. Hirst. Oak Ridge National Laboratory, Oak Ridge, Tenn.

77 Regulatory Responslbillty for Utillty integrated Resource Planning ORNL/CON-249 (January 1988)

E. Hirst. Oak Ridge National Laboratory, Oak Ridge, Tenn.

78 Key Issues for State Regulators on Electric-UtIIIty Integrated Resource Planning

Proceedirigs of the 27th Regulatory Conference, lowa State University, Ames, May 1988, pp. 366-76 (1988)

E. A. Hirst. Oak Ridge National Laboratory, Oak Ridge, Tenn.

79 FInancing Energy Conservation: Innovative Approaches with Geographic Problems

The Canadian Geographer 32(2), pp. 169-72 (1988)

M. A. Brown. Oak Ridge National Laboratory, Oak Ricige, Tenn.

80 Stimulating Energy Conservation by Sharlng the Savings: A CommunityBased Approach

Environment and Planning A 20, pp. 517-34 (1988)

M. A. Brown, D. L. White. Oak Ridge National Laboratory, Oak Ridge, Tenn.

81 Occupant Evaluation of Commerclal Office Lighing: Volume II, Prollminary Data Analysis

ORNL/TM-10264/N2 (November 1987)

R. W. Marans. University of Michigan, Ann Arbor, Mich.

M. A. Brown. Oak Ridge National Laboratory, Oak Ridge, Tenn.

82 Hood River Conservation Project Load Analysis

ORNL/CON-240 (November 1987)

T. K. Stovall. Oak Ridge National Laboratory, Oak Ridge, Tenn.

83 Impact of the Hood Rlver Conservation Project on Electriclty Use for Residentlal Water Heating

ORNL/CON-238 (October 1987)

M. A. Brown, D. L. White, S. L. Purucker. Oak Ridge National Laboratory, Oak Ridge, Tenn.

84 An Analysis of the Impact of Residentlal Retrofits on Indoor Temperature Cholce

ORNL/CON-236 (October 1987)

T. M. Dinan. Oak Ridge National Laboratory, Oak Ridge, Tenn.

85 Use of Wood for Space Heating: Analysis of Hood River Conservation Prolect Submetered Homes

ORNL/CON-234 (September 1987)

B. E. Tonn, D. L. White. Oak Ridge National Laboratory, Oak Ridge, Tenn. 
Analysis and Evaluation

86 Weatherlzation Assistance for Low-Income Households: An Evaluation of LOCal Program Performance

ORNL-6337 (August 1987)

M. Schweitzer, S. Rayner, A. K. Wolfe. Oak Ridge National Laboratory, Oak Binge, Tenn.

T. W. Mason. T. W. Mason Associates, P.C., Knoxville, Tenn.

B. R. Ragins. Marquette University, Milwaukee, Wis.

R. A. Cantor. University of Tennessee, Knoxville, Tenn.

87 Evaluation Design: Factors in the Organization of Evaluation as an Extension of the Theory of Evaluation Design

Proceedings of the 1987 Conference on Energy Conservation Program Evaluation:

Practical Methods, Useful Results 2, pp. 283-94 (August 1987)

H. G. Peach. Pacific Power and Light Co., Portland, Ore.

E. A. Hirst. Oak Ridge National Laboratory, Oak Ridge, Tenn.

88 Occupant Evaluation of Commerclal Office Lighting: Volume 3, Data Archive and Database Management System

ORNLTM-10264/N3, ed. M. A. Brown (August 1987)

G. Gillette. American Institute of Architects Foundation, Washington, D.C.

89 Expert Systems and Mlcrowave Communication Systems Alarms Processing: A Feasibllity Study

ORNLITM-10429 (July 1987)

B. E. Tonn, R. T. Goeltz, S. Punucker. Oak Ridge National Laboratory, Oak Ridge, Tenn.

90 Elecirlc Utillty Energy Conservation and Load Management Programs:

Current Activities at Ten Utilities

Electric Potential 3(3), pp 20-32 (May-June 1987)

E. Hirst. Oak Ridge National Laboratory, Oak Ridge, Tenn.

91 Answering Behavloral Questlons about Energy Efflclency in Bulldings Energy 12(5), pp. 339-53 (May 1987)

P. C. Stern. National Research Cour.cil, Washington, D.C.

E. Aronson. University of Califomia, Santa Cruz, Calif.

J. M. Darley, W. Kempton. Princeton University, Princeton, N.J.

D. H. Hill. University of Michigan, Ann Arbor, Mich.

E. Hirst, T. J. Wilbanks. Oak Ridge National Laboratory, Oak Ridge, Tenn.

92 Investigations of Varlations In Monthly Market Shares of Light-Duty

Vehlcles

ORNLTM-10248 (May 1987)

P. S. Hu, R. Lee. Oak Ridge National Laboratory, Oak Ridge, Tenn.

93 Electriclty Use and Savings In the Hood RIver Conservation Project ORNL/CON-231 (April 1987)

E. Hirst, R. Goeltz, D. Trumble. Oak Ridge National Laboratory, Oak Ridge, Tenn.

94 Transportation Energy Data Book: Edition 9

ORNL-6325 (March 1987)

M. C. Holcomb, S. D. Floyd. Oak Ridge National Laboratory, Oak Ridge, Tenn.

S. L. Cagle. University of Tennessee, Knoxville, Tenn.

95 Impact Analysls of a Residentlal Energy Conservation Shared Savings Program: The General Public Utilities Experlence

ORNL/CON-217 (February 1987)

M. A. Brown, D. L. White. Oak Ridge National Laboratory, Oak Ridge, Tenn. 
96 Motor Vehicle MPG and Market Shares Report: Model Year 1986 ORNL-6351 (February 1987)

P. S. Hu. Oak Ridge National Laboratory, Oak Ridge, Tenn.

L. S. Buckels. University of Tennessee, Knoxville, Tenn.

97 A Comparative Analysls of UtIlity- and Non-UtIlity-Based Energy Service Companles: A Case Study Approach

ORNL/Sub/84-19701/1 (January 1987)

Consumer Energy Council of America Research Foundation. Washington, D.C.

9 Inventory of Energy Research In Schools of Archltecture 1972-1985 ORNL/Sub/84-89680/1 (January 1987)

D. Prowler, E. Johnson-Mohler, M. Aseltine. University of Pennsylvania, Philadelphia, Pa.

99 The Diffusion of Ideas and Innovations

International Encyclopedia of Communications, ed. E. Bamouw (New York: Oxford University Press, 1987)

M. A. Brown. Oak Ridge National Laboratory, Oak Ridge, Tenn. 


\section{BUILDING EQUIPMENT RESEARCH}

100 Report Style Gulde for Subcontractors of the Efficlency and Renewables Research Section, Energy Divislon, Oak Ridge National Laboratory ORNLTM-12082 (September 1992)

T. A. Stone, M. N. Bennett. Oak Ridge National Laboratory, Oak Ridge, Tenn.

101 An Assessment of Desiccant Coollng and Dehumidification Technology ORNUCON-309 (July 1992)

V. C. Mei, F. C. Chen. Oak Ridge National Laboratory, Oak Ridge, Tenn.

Z. Lavan. Illinois Institure of Technology, Chicago, III.

R. K. Collier, Jr. Collier Engineering Senvices, Mieritt Island, Fla.

G. Meckler. Gershon Meckler Associates, P.C., Hemdon, Va.

102 Global Warming Implication of Replacing CFCs: Combining Energy and Fiuorocarbon Emission Effects ASHRAE Journa/ 34(4), pp. 14-19 (April 1992)

S. K. Fischer, P. D. Fairchild, P. J. Hughes. Oak Ridge National Laboratory, Oak Ridge, Tenn.

103 Development and Proof-Testing of Advanced Absorption Refrigeration Cycle Concepts. Report on Phases I and IA

ORNL/Sub/86-17498/1 (March 1992)

R. J. Modahl, F. C. Hayes. The Trane Company, La Crosse, Wisc.

104 Alternatlves to CFCs and Global Warming: A Systems Approach to Evaluating Net Contributions

Materials Research Society Bulletin XVII(3), pp. 39-42 (March 1992)

S. K. Fischer. Oak Ridge National Laboratory, Oak Ridge, Tenn.

M. McFarland. E. I. du Pont de Nemours \& Co., Inc., Wilmington, Del.

105 Modeled Performance of Non-Chlorinated Substitutes for CFC-11 and CFC-12 Centrifugal Chlllers

ORNL/M-2391 (1992)

J. R. Sand, S. K. Fischer. Oak Ridge National Laboratory, Oak Ridge, Tenn.

106 Market Potentlal Estimates and R\&D Planning for Advanced Absorption Systems for Large Commerclal Bulldings

ASHRAE Transactions 98(2), pp. 156-64 (Atlanta, Ga.: American Society of Heating,

Refrigerating, and Air-conditioning Engineers, 1992)

J. M. MacDonald, P. J. Hughes, H. A. McLain. Oak Ridge National Laboratory, Oak Ridge, Tenn.

107 Flow Bolling Enhancement of R22 and a Nonazeotropic Mixture of R143a and R124 Using Perforated Folls

ASHRAE Transactions 98(2), pp. 402-10 (Atlanta, Ga.: American Society of Heating, Refrigerating, and Air-conditioning Engineers, 1992)

J. C. Conklin, E. A. Vineyard. Oak Ridge National Laboratory, Oak Ridge, Tenn.

108 An Analytical Screening of Alternatlves for R-502 in Low-Temperature Refrigerating Applications

ASHRAE Transactions 98(2), pp. 188-203 (Atlanta, Ga.: American Society of Heating,

Refrigerating, and Air-conditioning Engineers, 1992)

S. K. Fischer. Oak Ridge National Laboratory, Oak Ridge, Tenn. 
109 Benchmark Performance Analysis of an ECM-Modulated Alr-to-Alr Heat Pump with a Reclprocating Compressor

ASHRAE Transactions 98(1), pp. 430-50 (Atlanta, Ga.: American Society of Heating,

Refrigerating, and Air-conditioning Engineers, 1992)

C. K. Rice. Oak Ridge National Laboratory, Oak Ridge, Tenn.

110 Modeled Performance of Non-Chlorinated Substltutes for CFG-11 and CFC.12 In Centrlfugal Chillers

Proceedings of the 1991 International CFC and Halon Alternatives Conference,

Baltimore, Md., December 3-12, 1991 (Baltimore, Md.: December 1991)

J. R. Sand, S. K. Fischer. Oak Ridge National Laboratory, Oak Ridge, Tenn.

P. A. Joyner. Eiectric Power Research Institute, Palo Alto, Calif.

111 Total Equivalent Global Warming Impact: Combining Energy and Fluorocarbon Emission Effects

Proceedings of the 1991 Intemational CFC and Halon Altematives Conference,

Baltimore, Md., December 3-12, 1991, pp. 790-800 (Baltimore, Md.: December 1991)

P. D. Fairchild, S. K. Fischer, P. J. Hughes. Oak Ridge National Laboratory, Oak Ridge, Tenn.

112 Absorption Chillers: Part of the Solution

Proceodings of the 1991 International CFC and Halon Alternatives Conference,

Baltimore, Md., December 3-12, 1991, pp. 364-74 (Baltimore, Md.: December 1991)

P. J. Hughes. Oak Ridge National Laboratory, Oak Ridge, Tenn.

A. J. Occhionero. American Gas Cooling Center, Arlington, Va.

E. A. Reid. Columbia Gas Distribution Company, Columbus, Ohio

113 Analysis of Non-CFC Automotive Alr Conditioning

Proceedings of the 1991 International CFC and Halon Alternatives Conference,

Baltimore, Md., December 3-12, 1991 (Baltimore, Md.: December 1991)

V. C. Mei, F. C. Chen. Oak Ridge National Laboratory, Oak Ridge, Tenn.

R. Sullivan. Otfice of Conservation and Renewable Energy, U.S. Department of Energy, Washington, D. C.

114 Overview of CFC Repiacement Issues for Household Refrigeration Proceedings of the 1991 International CFC and Halon Alternatives Conference,

Baltimore, Md., December 3-12, 1991, pp. 310-16 (Baltimore, Md.: December 1991)

E. A. Vineyard. Oak Ridge National Laboratory, Oak Ridge, Tenn.

L. Roke. Fisher \& Paykel, Greenmount, Auckland, New Zealand

F. Hallett. Frigidaire, Washington, D. C.

115 Computer Model for SImulation of Absorption Systems in Flexible and Modular Form

ORNL/Sub/90-89673 (August 1991)

G. Grossman, K. Gommed, D. Gadoth. Technion Israel Institute of Technology, Haira, Israel

116 Estimated Slze and Performance of a Natural Gas Fired Duplex Stirling for Domestic Refrigeration Applications

Proceedings of the XVIII Intemational Congress of Refrigeration, Montreal, Canada,

August 10-15, 1991 (Paris: International Institute of Refrigeration, 1991)

D. M. Berchowitz. Sunpower, Inc., Athens, Ohio

J. A. Shonder. Oak Ridge National Laboratory, Oak Ridge, Tenn. 
117 Heat Exchanger Thermal Performance for Two Nonazeotroplc Refrigerant Mixtures

Proceedings of the XVIII International Congress of Refrigeration, Montreal, Canada, August 10-15, 1991 (Paris: International Institute of Refrigeration, 1991)

J. C. Conklin, E. A. Vineyard. Oak Ridge National Laboratory, Oak Ridge, Tenn.

118 Advantages of Enthalpy-Temperature Dlagrams for Nonazeotroplc Refrigerant Mixtures

Proceodings of the XVIII Intemational Congress of Refrigeration, Montreal, Canada,

August 10-15, 1991 (Paris: International Institute of Refrigeration, 1991)

J. C. Conklin, J. R. Sand. Oak Ridge National Laboratory, Oak Ridge, Tenn.

E. Granryd. Royal Institute of Technology, Stockholm, Sweden

119 Cycle Performance Comparison Between A Nonazeotropic Refrigerant Mixture and R-22

Proceedings of the XVIII Intemational Congress of Refrigeration, Montreal, Canada,

August 10-15, 1991 (Paris: International Institute of Refrigeration, 1991)

E. A. Vineyard, J. C. Conklin. Oak Ridge National Laboratory, Oak Ridge, Tenn.

120 Tubeside Condensation of Nonazeotroplc Refrigerant Mlxtures for Two Enhanced Surfaces

Proceedings of the ASME/JSME Thermal Engineering Joint Conference 3, pp. 251-56

(New York: American Society of Mechanical Engineers, March 1991)

J. C. Conklin, E. A. Vineyard. Oak Ridge National Laboratory, Oak Ridge, Tenn.

121 Heat Transfer of Buried Pipe for Heat Pump Application

ASME Journal of Solar Energy Engineering 113, pp. 51-55 (February 1991)

V. C. Mei. Oak Ridge National Laboratory, Oak Ridge, Tenn.

122 Braun Heat Pump Engine/Compressor and its Hermetic Rod Seal Proceedings of the 26th Intersociety Energy Conversion Engineering Workshop, Boston, Massachusetts, August 1991 91-2, p. 510 (LaGrange Park, III.: American Nuclear Society, Inc., August 1991)

A. T. Braun, M. S. Alam. Tectonics Research, Inc., Minneapolis, Minn.

R. J. Fiskum. Otfice of Conservation and Renewable Energy, U.S. Department of Energy, Washington, D. C.

123 Optlons of Desiccant Cooling and Dehumidification Technology Proceedings of the 26th Intersociety Energy Conversion Engineering Workshop, Boston, Massachusetts, August 1991 91-2, p. 566 (LaGrange Park, III.: American Nuclear Society, Inc., August 1991)

E. Kweller. Office of Conservation and Renewable Energy, U.S. Department of Energy, Washington, D. C.

V. C. Mei, F. C. Chen. Oak Ridge National Laboratory, Oak Ridge, Tenn.

124 Residential Absorption Heat Pump Using a Generator-Absorber Heat Exchange Cycle

Proceodings of the 26th Intersociety Energy Conversion Engineering Workshop, Boston, Massachusetts, August 1991 91-2, p. 498 (LaGrange Park, III.: American Nuclear Society, Inc., August 1991)

B. A. Phillips. Phillips Engineering Company, St. Joseph, Mich.

R. C. DeVault. Oak Ridge National Laboratory, Oak Ridge, Tenn. 
125 Natural Gas Fueled Combustor for a 3 kW Output Stirling Englne Proceedings of the 26th Intersociety Energy Conversion Engineering Workshop, Boston, Massachusetts, August 1991 91-2, p. 566 (LaGrange Park, III.: American Nuclear Society, Inc., August 1991)

W. D. Waldron, G. T. Riecke. Mechanical Technology, Inc., Latham, N.Y.

126 Experimental Study of the Effects of Alcohol Additives in Lithlum Bromlde Water Pool Absorbers

ASHRAE Transactions 97(2), pp. 403-405 (Atlanta: American Society of Heating,

Refrigerating, and Air-conditioning Engineers, 1991)

Y. Elkassabgi. Texas A\&I University, Kingsville, Texas

H. Perez-Blanco. Pennsylvania Stale University, University Park, Penn.

127 The Alternative Refrigerant Dllemma for Refrlgerator-Freezers: Truth or Consequences

ASHRAE Transactions 97(2), pp. 955-60 (Atlanta: American Society of Heating,

Refrigerating, and Air-conditioning Engineers, 1991)

E. A. Vineyard. Oak Ridge National Laboratory, Oak Ridge, Tenn.

128 Thermal Performance Analys/s for Heat Exchangers Using Nonazeotroplc Refrigerant Mixtures

Proceedings Winter Meeting ASME, Dallas, Texas, November 25-30, 1990, Symposium on Heat Transfer in Advanced Energy Systems AES 18/HTD 151, pp. 25-32 (New

York: American Society of Mechanical Engineers, November 1990)

E. Granryd. Royal Institute of Technology, Stockholm, Sweden

J. C. Conklin. Oak Ridge National Laboratory, Oak Ridge, Tenn.

129 Development of a High-Efflclency, Gas-Fired, Absorption Heat Pump for Residentlal and Small-Commerclal Applications. Phase I Final Report. Analysis of Advanced Cycles and Selection of the Preferred Cycle ORNL/SUb/86-24610/1 (September 1990)

B. A. Phillips. Phillips Engineering Co., St. Joseph, Mich.

130 Performance Testing of a Commerclally Produced Cryogenlc Refrigerator ORNL/TM-10809 (September 1990)

E. G. Keshock. University of Tennessee, Knoxville, Tenn.

R. W. Murphy. Oak Ridge National Laboratory, Oak Ridge, Tenn.

131 Initlal Parametric Results Using CYCLEZ-An LMTD-Speciffed, LorenzMeutzner Cycle Refrigerator-Freezer Model

ASHRAE/Purdue CFC Conference Proceedings, pp. 448-58 (West Lafayette, Ind.:

Purdue University, July 1990)

C. K. Rice, J. R. Sand. Oak Ridge National Laboratory, Oak Ridge, Tenn.

132 Thermodynamic Calculations for Mixtures of Environmentally Safe

Refrigerants Using the Lee-Kesler-Plocker Equation of State

ASHRAE/Purdue CFC Conference Proceedings, pp. 373-82 (West Lafayette, Ind.:

Purdue University, July 1990)

S. K. Fischer, J. R. Sand. Oak Ridge National Laboratory, Oak Ridge, Tenn.

133 Energy Use Impact of CFC Alternatives

Proceedings of the Fitth Cogeneration and Independent Power Congress, 1990 HVAC

\& Controls Symposium \& Expo Section (Boston, Mass.: Association of Energy

Engineers, June 1990)

S. K. Fischer. Oak Ridge National Laboratory, Oak Ridge, Tenn. 
134 Develo,oment of Design Guldellnes for Direct Expansion Ground Coll Heat Exchangers for Ground Coupled Heat Pump Systems

EPRI CU-6828 (Palo Alto, Calif.: Electric Power Research Institute, May 1990)

V. C. Mei, V. D. Baxter. Oak Ridge National Laboratory, Oak Ridge, Tenn.

135 An Exporimental Evaluation of Two Nonazeotroplc Refrigerant Mixtures in a Water-to-Water, Breadboard Heat Pump

ORNL/M-1117 (April 1990)

M. Kauffield, W. Mulroy, M. McLinden, D. Didion. National Institute of Standards and Technology, Gaithersburg, Md.

136 Triple Effect Absorption Chiller Cycle: A Step Beyond Double-Effect Cycles

Proceedings of the IEA Annex XVI Workshop on High Performance Heat Pumps, Susono City, Japan, Report No. HPB-WR-6, pp. II-27-40 (March 1990)

R. C. DeVault. Oak Ridge National Laboratory, Oak Ridge, Tenn.

137 A Menu-Drlven Program for Determining Propertles of Aqueous Lithium Bromide Solutlons

ORNL/TM-11331 (January 1990)

M. R. Patterson, H. Perez-Blanco. Oak Ridge National Laboratory, Oak Ridge, Tenn.

R. N. Crosswhite. Oak Ridge Associated Universities, Oak Ridge, Tenn.

138 A Magnetically Coupled Stirling Englne Driven Heat Pump: Design Optimization and Operating Cost Analysis

Proceodings of the 25th Intersociety Energy Conversion Engineering Conference, 2, pp. 204-10 (New York: American Institute of Chemical Engineers, 1990)

R. J. Vincent, W. Waldron. Mechanical Technology, Inc., Latham, N.Y.

13 s Study of Asymmetric Supersonic Jet Flow for Ejectors

Thermo-Physical Aspects of Energy Conversion, AES 16, pp. 55-66 (New York:

Amarican Society of Mechanical Engineers, 1990)

C. M. Ho. University of Southem California, Los Angeles, Calif.

G. S. Knoke. BDM inc., Seattle, Wash.

E. W. Geller, H. T. Liu. Flow Research, Inc., Kent, Wash.

W. H. Jou. Flow Research, Inc., Seattle, Wash.

R. W. Murphy, F. C. Chen. Oak Ridge National Laboratory, Oak Ridge, Tenn.

140 Hardware Development and Initlal Subassembly Test of a Gas-Fired Stirling-Rankine Residential Heat Pump

Proceedings of the 25th Intersociety Energy Conversion Engineering Conferance, 5, pp. 258-63 (New York: American Institute of Chemical Engineers, 1990)

G. Chen, J. McEntee. Sunpower, Inc., Athens, Ohio

141 Advanced Absorption Technology Development In the United States Heat Pumps Solving Energy and Environmental Challenges. Proceedings IEA Heat Pump Conference, Tokyo, Japan, March 12-15, 1990, pp. 69-80 (Pergamon Press, 1990)

R. C. DeVault. Oak Ridge National Laboratory, Oak Ridge, Tenn.

142 Performances of Four Magnetlc Heat Pump Cycles

Thermo-Physical Aspects of Energy Conversion, AES 16, pp. 103-15 (New York:

American Society of Mechanical Engineers, 1990)

F. C. Chen, R. W. Murphy, V. C. Mei. Oak Ridge National Laboratory, Oak Ridge, Tenn.

G. L. Chen. Sunpower, Inc., Athens, Ohio 
143 Energy Technology R\&D and the Greenhouse Effect

Heat Pumps Solving Energy and Environmental Challenges. Proceedings of the IEA Heat Pump Conference, Tokyo, Japan, March 12-15, 1990, pp. 231-41 (Pergamon Press, 1990)

P. D. Fairchild, W. Fulkerson. Oak Ridge National Laboratory, Oak Ridge, Tenn.

144 Absorption Flulds Data Survey. 1989 Update ORNL/Sub/84-47989/4 (October 1989)

R. A. Macriss, T. S. Zawacki. Institute of Gas Technology, Chicago, III.

145 Free-PIston Stirling Englne Magnetically Coupled Heat Pump: Critical Component Evaluation. Phase I Final Report

ORNL/Sub/86-SA578/1 (August 1989)

G. Chen. Sunpower, Inc., Athens, Ohio

146 Laboratory Study of the Dynamic Losses of a Single Speed, Spllt System Alr-to-Alr Heat Pump Having Tube and Plate Fin Heat Exchangers ORNL/CON-253 (August 1989)

W. A. Miller. Oak Ridge National Laboratory, Oak Ridge, Tenn.

147 Selectlon of Ozone-Free, Nonazeotroplc Refrlgerant Mixtures for Capaclty Modulation in Residential Heat Pumps

ASHRAE Transactions 95(1), pp. 34-46 (Atlanta: American Society of Heating, Refrigerating, and Air-Conditioning Engineers, June 1989)

E. A. Vineyard, J. R. Sand. Oak Ridge National Laboratory, Oak Ridge, Tenn.

T. G. Statt. Department of Energy, Washington, D.C.

148 Refrlgerator-Freezer Energy Testing with Alternatlve Refrigerants CFCs: Time of Transition, pp. 205-10 (Atlanta: American Society of Heating,

Refrigerating, and Air-Conditioning Engineers, June 1989)

E. A. Vineyard, J. R. Sand, W. A. Miller. Oak Ridge National Laboratory, Oak Ridge, Tenn.

149 Energy-Use Impact of Chlorofluorocarbon Alternatives

ORNL/CON-273 (February 1989)

S. K. Fischer, F. A. Creswick. Oak Ridge National Laboratory, Oak Ridge, Tenn.

150 Dynamic Characteristics Concerned in the Design of a Free-PIston StIrling Englne/Magnetlc Coupling/Compressor

Proceedings of the 24th Intersociety Energy Conversion Engineering Conference, Washington, D.C., August 1989 5, pp. 2219-23 (1989)

G. Chen. Sunpower, Inc., Athens, Ohio

151 System Design and Performance Prediction of a Free-PIston Stirling Engine/Magnetic Coupling/Compressor Assembly in a Gas Residential Heat Pump

Advances in Heat Pumps 1989, AES 7/HTD 125, pp. 81-86 (New York: American

Society of Mechanical Engineers, 1989)

G. Chen, W. T. Beale. Sunpower, Inc., Athens, Ohio

152 Magnetically Linked Free-Piston Stirling-Refrigerant Compressor Heat Pump

Analysis and Applications of Heat Pumps, AES 8/SED 6, pp. 57-60 (New York:

American Society of Mechanical Engineers, 1989)

G. Chen, W. T. Beale. Sunpower, Inc., Athens, Ohio 
153 Heat Transfer of Burled Plpe for Heat Pump Application

Advances in Heat Pumps-1989 AES 7/HTD 125, pp. 23-29 (New York: American Society of Mechanical Engineers, 1989)

V. C. Mei. Oak Ridge National Laboratory, Oak Ridge, Tenn.

154 Motor Current SIgnature Analysis A Potentlal Diagnostic for Air Conditioners

ASHRAE Transactions 95(1), pp. 312-17 (Atlanta: American Society of Heating,

Refrigerating, and Air-Conditioning Engineers, 1989)

W. A. Miller, H. D. Haynes, F. P. Griffin, W. P. Levins, M. A. Karnitz. Oak Ridge National Laboratory, Oak Ridge, Tenn.

155 Comparlson of Thermoelectric and Vapor Cycle Technologies for Groundwater Heat Pump Application

ASME Journal of Solar Energy Engineering 111, pp. 353-57 (1989)

V. C. Mei, F. C. Chen. Oak Ridge National Laboratory, Oak Ridge, Tenn.

B. Mathiprakasam. Midwest Research Institute, Kansas City, Mo.

156 Advanced Evacuated Thermal Insulations: The State of the Art Thermal Insulation 12, pp. 183-208 (1989)

H. A. Fine. University of Kentucky, Lexington, Ky.

157 Research and Development on Heat Pumps for Space Conditioning Applications. Proceedings of the 2nd DOE/ORNL Heat Pump Conference, Washington, D.C., AprII 17-20, 1988 CONF-8804100 (August 1988)

E. T. Rogers, ed. Oak Ridge National Laboratory, Oak Ridge, Tenn.

158 Potentlal Impacts of CFC Restrictions on Refrigeration and SpaceConditioning Equipment

Intemational Journal of Refrigeration 11, pp. 217-21 (July 1988)

F. A. Creswick, S. K. Fischer, J. R. Sand. Oak Ridge National Laboratory, Oak Ridge, Tenn.

159 The Oak Rldge Heat Pump Design Model: Mark III Version Program Documentation ORNLTM-10192 (March 1988)

S. K. Fischer, C. K. Rice, W. L. Jackson. Oak Ridge National Laboratory, Oak Ridge, Tenn.

160 Absorption Flulds Data Survey: Final Report on Worldwide Data ORNL/Sub/84-47989/3 (February 1988)

R. A. Macriss, J. M. Gutraj, T. S. Zawacki. Institute of Gas Technology, Chicago, III.

161 Free-PIston Stirling Engine Diaphragm-Coupled Heat-Actuated Heat Pump Component Technology Program. Volume 2, Phase IIA and IIB Final Report, Lennox Test Program

ORNL/Sub/86-47985/2\&V2 (January 1988)

R. A. Ackermann. Mechanical Technology, Inc., Latham, N.Y.

162 Free-Plston Stirling Engine Diaphragm-Coupled Heat-Actuated Heat Pump Component Technology Program. Volume 1, Phase IIA and IIB Final Report, Technical Discussion

ORNL/Sub/86-47985/2\&V1 (January 1988)

R. A. Ackermann. Mechanical Technology, inc., Latham, N.Y. 
163 Field Performance Valldation of an Advanced Design Earth-Coupled Heat Pump System

ORNL/Sub/85-22035/1 (January 1988)

P. J. Hughes, R. J. Hackner. W. S. Fleming \& Associates, Inc., East Syracuse, N.Y.

164 Experimental Study of Short-Tube Refrigerant Flow

Analysis and Applications of Heat Pumps. Proceedings of the ASME Winter Annual

Meeting, Chicago, November 27-December 2, 1988, AES 8, pp. 37-42 (New York:

American Society of Mechanical Engineers, 1988)

V. C. Mei. Oak Ridge National Laboratory, Oak Ridge, Tenn.

165 Implications of CFC Ban on Natlonal Energy Use ASHRAE Journal 30, pp. 30-34 (1988)

S. K. Fischer, F. A. Creswick. Oak Ridge National Laboratory, Oak Ridge, Tenn.

166 Testing of a Stirling Cycle Cooler

Analysis and Applications of Heat Pumps. Proceedings of the ASME Winter Annual Meeting, Chicago, November 27-December 2, 1988, AES 8, pp. 49-55 (New York: American Society of Mechanical Engineers, 1988)

F. C. Chen, R. W. Murphy. Oak Ridge National Laboratory, Oak Ridge, Tenn.

E. G. Keshock. University of Tennessee, Knoxville, Tenn.

167 Numerical Fits of the Propertles of LIthlum-Bromide Water Solutlons ASHRAE Transactions 94(2), pp. 2059-77 (Atlanta: American Society of Heating, Refrigerating, and Air-Conditioning Engineers, 1988)

H. Perez-Blanco, M. R. Patterson. Oak Ridge National Laboratory, Oak Ridge, Tenn.

168 Laboratory Examination and Seasonal Analysis of the Dynamic Losses for a Continuously Varlable Speed Heat Pump ASHRAE Transactions 94(2), pp. 1246-68 (Atlanta: Arnerican Society of Heating, Refrigerating, and Air-Conditioning Engineers, 1988)

W. A. Miller. Oak Ridge National Laboratory, Oak Ridge, Tenn.

169 Two-Phase Refrlgerant Flow Measurement with Liquid and Vapor Separation Technlque ASHRAE Transactions 94(2), pp. 238-43 (Atlanta: American Snciety of Heating, Refrigerating, and Air-Conditioning Engineers, 1988)

V. C. Mei. Oak Ridge National Laboratory, Oak Ridge, Tenn.

170 A Model of an Ammonla-Water Falling Film Absorber ASHRAE Transactions 94(1), pp. 467-83 (Atlanta: American Society of Heating, Refrigerating, and Air-Conditioning Engineers, 1988)

H. Perez-Blanco. Oak Ridge National Laboratory, Oak Ridge, Tenn.

171 Evaluation of Capacity Modulation Using Nonazeotropic Refrigerant Mixtures

ASHRAE Transactions 94(1), pp. 292-303 (Atlanta: American Society of Heating, Refrigerating, and Air-Conditioning Engineers, 1988)

E. A. Vineyard. Oak Ridge National Laboratory, Oak Ridge, Tenn.

172 Modulating Heat Pump Component and Adjustable Speed Drive Efficlencles Measured In the Laboratory

ASHRAE Transactions 94(1), pp. 874-91 (Atlanta: American Society of Heating,

Refrigerating, and Air-Conditioning Engineers, 1988)

W. A. Miller. Oak Ridge National Laboratory, Oak Ridge, Tenn. 
173 Efficlency Characteristlcs of Speed Modulated Drlves at Predicted Torque Conditions for Alr-to-Alr Heat Pumps ASHRAE Transactions 94(1), pp. 892-921 (Atlanta: American Society of Heating, Refrigerating, and Air-Conditioning Engineers, 1988)

C. K. Rice. Oak Ridge National Laboratory, Oak Ridge, Tenn.

174 Heat Pump Grourid Coll Analysls with Thermal Interference ASME Journal of Solar Energy Engineering 110, pp. 67-73 (1988)

V. C. Mei. Oak Ridge National Laboratory, Oak Ridge, Tenn.

175 Measurements of Heat-Transfer Coefficients of Nonazeotroplc Refrigerant Mixtures Condensing Inslde Horizontal Tubes ORNLSUb/81-7762/6801 (November 1987)

D. DeGrush, W. F. Stoecker. University of Illinois Urbana-Champaign, Urbana, III.

176 Freo-PIston Stirling Englne Dlaphragm-Coupled Heat-Actuated Heat Pump Component Technology Program. Phase 1B Final Report ORNL/Sub-83/47985/1 (September 1987)

R. A. Ackermann. Mechanical Technology, Inc., Latham, N.Y.

177 Free-Plston Stirling Englne Dlaphragm-Coup?ed Heat-Actuated Heat Pump Component Technology Program. Phase 1C Final Report ORNLSUb-86/47985/1 (July 1987)

R. A. Ackermann. Mechanical Technology, Inc., Latham, N.Y.

178 U.S. Heat Pump Research and Development Projects 1976-1986 ORNLCON-224 (April 1987)

K. H. Zimmerman. Oak Ridge National Laboratory, Oak Ridge, Tenn.

179 Absorption Fluids Data Survey: Final Report on Forelgn Data ORNL/Sub/84-47989/2 (April 1987)

R. A. Macriss, J. M. Gutraj, T. S. Zawacki. Institute of Gas Technology, Chicago, III.

180 Final Report: 1984-85 Annual Performance Testing and Analysis of Two Horizontal Coll Ground-Coupled Heat Pump Systems ORNL/Sub/81-\%685/4\&92 (April 1987)

W. S. Johnson, B. A. McGraw, R. N. Baugh, W. Gritfith. University of Tennessee, Knoxville, Tenn.

181 Impact of Refrigerant Property Uncertalnties on Prediction of Vapor Compression Cycle Performance NBSIR 86-3373 (February 1987)

P. A. Domanski, D. A. Didion. National Bureau of Standards, Gaithersburg, Md.

182 A Comparlson of Cyllnder Heat Transfer Expressions Based on Prediction of Gas Spring Hysteresis Loss

Fluid Flow and Heat Transfer in Reciprocating Machinery. Proceedings of the ASME Winter Annual Meeting, Boston, Mass., December 13-18, 1987, ed. T. Morel et al., pp. 89-96 (New York: American Society of Mechanical Engineers, 1987)

A. A. Kornhauser, J. L. Smith, Jr. Massachusetts Institute of Technology, Cambridge, Mass. 
183 Estimated Fuel Savings for Heat Pump Systems That Comblne Ejectors and Engine-Driven Compressors

Fluid Flow and Heat Transfer in Reciprocating Machinery. Proceedings of the ASME Winter Annual Meeting, Boston, Mass., December 13-18, 1987, ed. T. Morel et al., paper no. 87-WAAES-4 (New York: American Society of Mechanical Engineers, 1987)

R. W. Murphy. Oak Ridge National Laboratory, Oak Ridge, Tenr

184 Comparlson of a Thermoelectric Coollng System and aroundwater Heat Pump

Fluid Flow and Heat Transfer in Reciprocating Machinery. Proceedings of the ASME Winter Annual Meeting, Boston, Mass., December 13-18, 1987, ed. T. Morel et al., paper no. 87-WAAES-3 (New York: American Society of Mechanical Engineers, 1987) V. C. Mei, F. C. Chen. Oak Ridge National Laboratory, Oak Ridge, Tenn.

B. Mathiprakasam. Midwest Research Institute, Kansas City, Mo.

185 Further Developments in the Design of a Free-Piston Stirling Engine Heat Pump for Residentlal Applications

ASHRAE Transactions 93(2), pp. 160-71 (Atlanta: American Society of Heating,

Refrigerating, and Air-Conditioning Engineers, 1987)

R. A. Ackermann. Mechanical Technology, Inc., Albany, N.Y.

J. M. Clinch. Gas Research Institute, Chicago, III.

G. T. Privon. Oak Ridge National Laboratory, Oak Ridge, Tenn.

186 Effect of Backflling Materlal on Ground Coll Performance

ASHRAE Transactions 93(2), pp. 1845-57 (Atlanta: American Society of Heating,

Refrigerating, and Air-Conditioning Engineers, 1987)

V. C. Mei. Oak Ridge National Laboratory, Oak Ridge, Tenn.

187 Steady-State Refrlgerant Flow and Alrflow Control Experiments for a Continuously Varlable Speed Alr-to-Alr Heat Pump

ASHRAE Transactions 93(2), pp. 1191-1204 (Atlanta: American Society of Heating,

Refrigerating, and Air-Conditioning Engineers, 1987)

W. A. Miller. Oak Ridge National Laboratory, Oak Ridge, Tenn.

188 Effects of Fin Pattern on the Alr-Side Heat Transfer Coefficlent in Plate Finned- Tube Heat Exchangers

ASHRAE Transactions 93(2), pp. 1961-84 (Atlanta: American Society of Heating,

Refrigerating, and Air-Conditioning Engineers, 1987)

D. T. Beecher, T. J. Fagan. Westinghouse Electric Corp., Pittsburgh, Pa.

189 Research Requirements in the Evaporative Cooling Fleld

ASHRAE Transactions 93(1), pp. 185-96 (Atlanta: American Society of Heating,

Refrigerating, and Air-Conditioning Engineers, 1987)

R. H. Tumer. University of Nevada, Reno, Nev.

F. C. Chen. Oak Ridge National Laboratory, Oak Ridge, Tenn.

190 The Effect of Vold Fraction Correlation and Heat Flux Assumption on Refrlgerant Charge Inventory Predictions

ASHRAE Transactions 93(1), pp. 341-67 (Atlanta: American Society of Heating,

Refrigerating, and Air-Conditioning Engineers, 1987)

C. K. Rice. Oak Ridge National Laboratory, Oak Ridge, Tenn.

191 Heat Pumps. Prospects in Heat Pump Technology Marketing

Chelsea, Michigan: Lewis Publishers, Inc., 1987

K. H. Zimmerman, R. H. Powell, Jr., eús. Oak Ridge National Laboratory, Oak Ridge, Tenn. 


\section{BUILDING THERMAL ENVELOPE SYSTEMS AND MATERIALS}

192 The Simulated Impact of Cllmate on the Drying Times of a Wetted Low. Slope Roof System

J. Thermal Insul. and Bldg. Envs. 16, pp. $234-45$ (January 1993)

A. O. Desjartais, D. M. Kyle, J. E. Christian. Oak Ridge National Laboratory, Oak Ridge, Tenn.

193 Gauge for Nondestructive Measurement of the Internal Pressure in Powder-filled Evacuated Panel Superinsulation

Rev. Sci. Instrum. 63(12), pp. 5774-79 (December 1992)

T. G. Kollie, L. S. Thacker. Oak Ridge National Laboratory, Oak Ridge, Tenn.

194 Llterature Revlew: Heat Transfer Through Two-Phase Insulation Systems Consisting of Powders in a Continuous Gas Phase

ORNL/M-2426 (December 1992)

D. W. Yarbrough. Oak Ridge National Laboratory, Oak Ridge, Tenn.

195 Molsture Effects In Low-Slope Roofs: Drying Rates After Water Addition with Varlous Vapor Retarders

ORNL/CON-308 (October 1992)

C. R. Pedersen. Danish Building Research Institute, Denmark

T. W. Petrie. Marquette University, Milwaukee, Wis.

G. E. Courville, A. O. Desjarlais, P. W. Childs, K. E. Wilkes. Oak Ridge National

Laboratory, Oak Ridge, Tenn.

196 A Study of Changes In Foundation Insulation Levels In the United States ORNL/CON-351 (October 1992)

J. E. Christian. Oak Ridge National Laboratory, Oak Ridge, Tenn.

M. K. Voss. St. Mary's College, Winona, Minn.

197 Numerical Analysis of Heat Transfer by Conduction and Natural Convection In Loose-FIII Fiberglass Insulation-Effects of Convection on Thermal Performance

ORNL/CON-338 (April 1992)

A. A. Delmas, K. E. Wilkes. Oak Ridge National Laboratory, Oak Ridge, Tenn.

198 Prellminary Evaluation of Radiation Control Coatings for Energy Conservation In Bulldings

ORNL/SUb/89-SE791/1 (February 1992)

R. W. Anderson. Robert W. Anderson and Associates, Inc., Boulder City, Nev.

199 The Effect of Compression on the Material R-Value of Flberglass Batt Insulation

J. Thermal Insul. 15 (January 1992)

R. S. Graves, D. W. Yarbrough. Oak Ridge National Laboratory, Oak Ridge, Tenn.

200 A Shape Factor Method for Computing Heating Loads from Bullding Slabon-Grade Foundations

pp. 166-75, Thermal Performance of the Exterior Envelopes of Buildings $V$, Proceedings of the ASHRAE/DOE/BTECC Conference, December 7-10, 1992,

Cleanwater Beach, Florida (Atlanta: American Society of Heating, Refrigerating, and Airconditioning Engineers, 1992)

W. W. Rust. Oak Ridge Associated Universities, Oak Ridge, Tenn.

J. E. Christian. Oak Ridge National Laboratory, Oak Ridge, Tenn. 
201 Thermal Performance of Flberglass and Cellulose Attic Insulations pp. 357-67, Thermal Performance of the Exterior Envelopes of Buildings $V$, Proceedings of the ASHRAE/DOE/BTECC Conference, December 7-10, 1992, Clearwater Beach, Florida (Atlanta: American Society of Heating, Refrigerating, and Airconditioning Engineers, 1992)

K. E. Wilkes, P. W. Childs. Oak Ridge National Laboratory, Oak Ridge, Tenn.

202 In-Situ Thermal Performance of APP Modified Bltumen Roof Membranes Coated with Reflectlve Coatings

pp. 420-28, Thermal Performance of the Exterior Envelopes of Buildings $V$,

Proceedings of the ASHRAE/DOE/BTECC Conference, December 7-10, 1992,

Clearwater Beach, Florida (Atlanta: American Society of Heating, Refrigerating, and Airconditioning Engineers, 1992)

J. D. Carlson, T. L. Smith. National Roofing Contractors Association, Rosemont, III.

J. E. Christian. Oak Ridge National Laboratory, Oak Ridge, Tenn.

203 Energy Efficlent Residential Bullding Foundations Enhance Indoor Alr Quallty

ASHRAE Journal 33(11), pp. 36-41 (November 1991)

J. E. Christian. Oak Ridge National Laboratory, Oak Ridge, Tenn.

204 Molsture Control Handbook: New, Low-rlse, Resldentlal Construction ORNL/Sub/89-SD350/1 (October 1991)

J. Lstiburek. Building Science Corp., Chestnut Hill, Mass.

J. Carmody. Underground Space Center, University of Minnesota, Minneapolis, Minn.

205 Corrosiveness of Wet Residential Bullding Thermal Insulation Mechanisms and Evaluation of Electrochemical Methods for Assessing Corrosion Behavior

ORNL/Sub/90-SF204/1 (October 1991)

E. E. Stansbury. Consultant to Oak Ridge National Laboratory, Oak Ridge, Tenn.

206 A Round Robin Evaluation of the Corrosiveness of Wet Residential Insulation by Electrochemical Measurements

ORNL/SUb/90-SF204/2 (October 1991)

E. E. Stansbury. Consultant to Oak Ridge National Laboratory, Oak Ridge, Tenn.

207 Laboratory Tests Results on the Thermal Resistance of Polylsocyanurate

Foamboard Insulation Blown With CFC-11 Substitutes-A Cooperative Industry/Government Project

ORNL/TM-11645 (September 1991)

D. L. McElroy, R. S. Graves, D. W. Yarbrough, F. J. Weaver. Oak Ridge National Laboratory, Oak Ridge, Tenn.

208 A Review of Vacuum Insulation Research and Development in the Bullding Materials Group of the Oak Rldge National Laboratory

ORNLTM-11703 (September 1991)

T. G. Kollie, D. L. McElroy, R. S. Graves, F. J. Weaver. Oak Ridge National Laboratory, Oak Ridge, Tenn.

H. A. Fine. University of Kentucky, Lexington, Ky.

K. W. Childs. Martin Marietta Energy Systems, Inc., Oak Ridge, Tenn. 
209 Interlaboratory Comparlson of Four Heat Flow Meter Apparatuses an Planed Polylsocyanurate Boards Foamed with CFC-11

ORNLTM-11720 (June 1991)

R. S. Graves, D. L. McElroy. Oak Ridge National Laboratory, Oak Ridge, Tenn.

R. U. Miller. Jim Walter Research Corp., St. Petersburg, Fla.

D. W. Yarbrough. Tennessee Technological University, Cookeville, Tenn.

R. R. Zarr. National Institute of Standards and Technology, Gaithersburg, Md.

2.1 Technics: Under Steep Roofing

Progressive Architecture, pp. 54-56 (May 1991)

J. E. Christian. Oak Ridge National Laboratory, Oak Ridge, Tenn.

211 Bullder's Foundation Handbook

ORNL/CON-295 (May 1991)

J. Carmody. Underground Space Center, University of Minnesota, Minneapolis, Minn.

J. Christian. Oak Ridge National Laboratory, Oak Ridge, Tenn.

K. Labs. Undercurrent Design Research, New Haven, Conn.

212 Thermal Properties of Polylsocyanurate Foam Board Insulation Blown WIth CFC-11 Substltutes

Proc. Third International Symposium on Roofing Technology, Montreal, Canada, April 17-19, 1091, pp. 133-42 (Rosemont, III.: National Roofing Contractors Association, Apri! 1991)

D. L. McElroy, G. E. Courvilie, J. E. Christian, R. L. Linkous, R. S. Graves. Oak Ridge

National Laboratory, Oak Ridge, Tenn.

213 Steady-State and Translent Tests Using the Unguarded ThIn-Heater Apparatus (Thermophysical Propertles of Bullding Materlals) ORNLTM-11629 (March 1991)

D. L. McElroy, R. S. Graves, D. W. Yarbrough. Oak Ridge National Laboratory, Oak Ridge, Tonn.

H. A. Fine. University of Kentucky, Lexington, Ky.

214 Thermal Performance of HCFC-22 Blown Extruded Polystyrene Insulation Insu'ation Materials: Testing and Applications, 2nd Volume, ASTM STP 1116, ed. R. S. Graves and D. C. Wysocki, pp. 214-28 (Philadelphia: American Society for Testing and Materials, 1991)

D. W. Yarbrough, R. S. Graves, J. E. Christian. Oak Ridge National Laboratory, Oak Ridge, Tenn.

215 Thermal Measisioment of In-situ and Thin-Speclmen Aging of Experimem... Polylsocyanurate Roof Insulation Foamed With Alternative Blowing Agents

Insulation Materials: Testing and Applications, 2nd Volume, ASTM STP 1116, ed. R. S. Graves and D. C. Wysocki, pp. 142-66 (Philadelphia: American Society for Testing and Materials, 1991)

J. E. Christian, G. E. Courville, R. S. Graves, R. L. Linkous, D. L. McElroy, F. J. Weaver, D. W. Yarbrough. Oak Ridge National Laboratory, Oak Ridge, Tenn.

216 ASHRAE Standard 90.2 Envelope Load Factors and Trade-off Procedures

ASHRAE Transactions 97(2), pp. 928-40 (1991)

M. F. McBride. Owens-Corning Fiberglas, Granville, Ohio

B. A. Wilcox. Berkeley Solar Group, Oakland, Calif.

J. E. Christian. Oak Ridge National Laboratory, Oak Ridge, Tenn. 
217 Thermal Mass Credits Relating to Bullding Enveiope Energy Standards ASHRAE Transactions 97(2), pp. 941-51 (1991)

J. E. Christian. Oak Ridge National Laburatory, Oak Ridge, Tenn.

218 ORNL's Search for Roof Insulation CFC Alternatives The Construction Specifier 43(11) (November 1990)

J. E. Christian. Oak Ridge National Laboratory, Oak Ridge, Tenn.

219 Assessment of the Energy Conservation Potentlal of Active (Varlable Thermal Res/stance and Switchable Absorptance) Bullding Thermal Insulation Systems ORNL/TM-11425 (June 1990)

H. A. Fine. University of Kentucky, Lexington, Ky.

D. L. McElroy. Oak Ridge National Laboratory, Oak Ridge, Tenn.

220 Fabrication, Evaluation, and Application of Evacuated Panel Insulation (EPI) to Portable Coolers

ORNL/Sub/88-SD731/1 (March 1990)

R. W. Barito, M. O. Barito. R. W. Barito \& Associates, Louisville, Ky.

T. G. Kollie, D. L. McElroy. F. J. Weaver, S. H. Werst, W. Chu. Oak Ridge National Laboratory, Oak Ridge, Tenn.

K. W. Childs. Martin Marietta Energy Systems, Inc., Oak Ridge, Tenn.

H. A. Fine. Consultant to Oak Ridge National Laboratory, Oak Ridge, Tenn.

H. L. Laridrum, Jr. Igloo Products Corp., Houston, Texas

221 Chlorofluorocarbon (CFC) Technologies Revlew of Foamed-Board Insulation for Bulldings

ORNLTM-11291 (March 1990)

D. L. McElroy. Oak Ridge National Laboratory, Oak Ridge, Tenn.

M.P. Scofield. U.S. Department of Energy, Office of Conservation and Renewable Energy, Washington, D.C.

222 Research and Development Data to Define the Thermal Performance of Reflectlve Materlals Used to Conserve Energy in Bullding Applications ORNL/Sub/88-SA835/1 (March 1990)

A. O. Desjarlais, R. P. Tye. Thermatest Division of Holometrix, Inc., Cambridge, Mass.

223 Proceedings of the Roof Wind Upllft Testing Workshop, Oak Ridge, Tennessee, November 8-9, 1989 CONF-891173 (February 1990)

G. E. Counville, comf.; P. S. Gillis, ed. Oak Ridge National Laboratory, Oak Ridge, Tenn.

224 Thermal Reslstance of Fine Powders at Atmospherlc Pressure and Under Vacuum

Insulation Materials, Testing, and Applications, ed. D. L. McElroy and J. F. Kimpflen, ASTM STP 1030, pp. 52-65 (Philadelphia, Pa.: American Society for Testing and Materials, 1990)

D. L. McElroy, F. J. Weaver, D. W. Yarbrough, R. S. Graves. Oak Ridge National Laboratory, Oak Ridge, Tenn. 


\section{Modeling of Thermal Resistance Test Conflgurations That Use Thin} Heaters

Insulation Materials, Testing, and Applications, ed. D. L. McElroy and J. F. Kimpflen, ASTM STP 1030, pp. 525-36 (Philadelphia, Pa.: American Society for Testing and Materials, 1990)

D. W. Yarbrough, D. L. McElroy, R. S. Graves. Oak Ridge National Laboratory, Oak Ridge, Tenn.

\section{The Most Needed Bullding Foundatlons Research Products}

Procoedings of Symposium on Insulation Materials, Testing, and Applications, Bal Hartor, Fla., December 7-9, 1987, ITP 1030, pp. 655-62 (Philadelphia: American Society for Testing and Materials, 1990)

J. E. Christian. Oak Ridge National Laboratory, Oak Ridge, Tenn.

227 An In Situ Evaluation of the Settling of Loose-Fill Rock Wool Insulation In the Attics of Two Manufactured Home Units

Proceedings of Symposium on Insulation Materials, Testing, and Applications, Bal Harbor, Fla., December 7-9, 1987, STP 1030, pp. 237-43 (Philadelphia: American Society for Testing and Materials, 1990)

R. S. Graves, D. W. Yarbrough. Oak Ridge National Laboratory, Oak Ridge, Tenn.

228 Evaluation of a Commerclal, Portable, Amblent-Temperature Emissometer Rev. Sci. Instrum. 61, pp. 1509-17 (1990)

T. G. Kollie, F. J. Weaver, D. L. McElroy. Oak Ridge National Laboratory, Oak Ridge, Tenn.

229 Bulldings Energy Research:

ORNLCON-292 (December 1989)

\section{A Blbllography Update}

R. S. Weaver, L. F. Goins, P. M. Love. Oak Ridge National Laboratory, Oak Ridge, Tenn.

230 Catalog of Thermal Bridges in Commerclal and Multl-Family Residential Construction ORNL/SUb/88-SA407/1 (December 1989)

A. N. Tuluca, D. M. Evans, K. Kuman, M. Krarti. Steven Winter Associates, Inc., New York, N.Y.K. W. Childs. Martin Marietta Energy Systems, Inc., Oak Ridge, Tenn.

G. E. Courville. Oak Ridge National Laboratory, Oak Ridge, Tenn.

T. Vonier. Thomas Vonier Associates, Inc., Washington, D.C.

R. Tye. Holometrix, Inc., Cambridge, Mass.

231 Measurement of Thermal Drift in Foam Insulation ORNL/TM-11290 (October 1989)

G. E. Courville, P. W. Childs. Oak Ridge National Laboratory, Oak Ridge, Tenn.

232 Overvlew of the Applicabllity of Electrochemical Methods to Evaluation of the Corrosiveness of Residentlal Bullding Thermal Insulations with Proposed Cooperative Test Program ORNL/Sub/87-B8240/1 (September 1989)

E. E. Stansbury. Consultant to Oak Ridge National Laboratory, Oak Ridge, Tenn.

233 U.S. Bullding Materlals Industry: R\&D Barrlers Assessment

ORNL/Sub/88-SB964/1 (September 1989)

F. H. Klareich, J. C. Frank. RCG/Hagler, Bailly, Inc., Washington, D.C. 
234 Guide for Estimuting Differences in Bullding Heating and Cooling Energy Due to Changes in Solar Reflectance of a Low-Sloped Roof

ORNL-6527 (August 1989)

E. I. Griggs. Tennessee Technological University, Cookeville, Tenn.

T. R. Sharp, J. M. MacDonald. Oak Ridge National Laboratory, Oak Ridge, Tenn.

235 Heat and Mass Transfer Through Porous Medla

ORNL/Sub/85-27486/2 (August 1989)

S. Motakef, L. R. Glicksman. Massachusetts Institute of Technology, Cambridge, Mass.

236 Model for Roof Thermal Performance

ORNL/CON-274 (July 1989)

K. E. Wilkes. Oak Ridge National Laboratory, Oak Ridge, Tenn.

237 International Symposium Proceedings on Mathematical Modeling of Roof Systems, Oak Ridge, Tennessee, September 15-16, 1988

CONF-8809314 (May 1989)

G. E. Courville, ed. Oak Ridge National Laboratory, Oak Ridge, Tenn.

238 The Roof Research Center - A Natlonal User Facillty for Thermal Performance and Durability of Roofing Systems. Users Manual. ORNL/M-329/2 (April 1989)

G. E. Courville. Oak Ridge National Laboratory, Oak Ridge, Tenn.

239 Design Description of the Large Scale Cllmate Simulator ORNLTM-10675 (March 1989)

W. R. Huntley. Oak Ridge National Laboratory, Oak Ridge, Tenn.

240 Changes in the Heating and Cooling Energy Use In Bulldings Due to Lowering the Surface Solar Absorptance of Roofs ORNLTM-10339 (February 1989)

E. I. Griggs. Tennessee Technological University, Cookeville, Tenn.

G. E. Counville. Oak Ridge National Laboratory, Oak Ridge, Tenn.

241 An Experimental Study of Stabllized Cellulosic Insulation Installed In Four Attic Sections of Manufactured Homes

ORNLTM-10775 (January 1989)

R. S. Graves, D. W. Yarbrough. Oak Ridge National Laboratory, Oak Ridge, Tenn.

242 ZIP-The ZIP.Code Insulation Program (Version 1.0). Economic Insulation Levels for New and Existing Houses by Three-Digit ZIP Code. Users Gulde and Reference Manual

ORNLTM-11009* (January 1989)

S. R. Petersen. National Institute of Standards and Technology, Gaithersburg, Md.

243 A Capacitance Probe for Measurement of Molsture Content in Open Pore Thermal Insulations

ORNL/Sub/85-27486/1 (January 1989)

S. Motakef, L. R. Glicksman. Massachusetts Institute of Technology, Cambridge, Mass.

-Also available as report no. NISTIR 88-3801 from the National institute of Standards and Technology, Gaithersburg, Maryland 20899. 
244 The Thermal Reslstance of Flat Powder-Filled Evacuated Panels Proceedir.gs of the Internaticnal Conference on Thermal Insulation, San Francisco, Califomia, February 27-March 1, 1989, 5, pp. 20-34 (Sunnyvale, Calif.: Product Safety Corporation, 1989)

R. S. Graves, D. W. Yarbrough, D. L. McElroy. Oak Ridge National Laboratory, Oak Ridge, Tenn.

245 Testing of Loose-FIII Cellulosic Insulation Taken From Residential Attics in Four Citles

Proceedings of the Second Califomia Thermal Insulation Conference, Sacramento, California September 18-20, 1989, ed. S. A. Siddiqui, pp. 86-97 (North Highlights, Calif.: Bureau of Home Furnishings and Thermal Insulation, 1989)

R. S. Graves, D. W. Yarbrough. Oak Ridge National Laboratory, Oak Ridge, Tenn.

246 Proceedings: Thermal Performance of the Exterlor Envelopes of Bulldings IV, December 4-7, 1989, Orlando, Florida

Atlanta: American Society of Heating, Refrigerating, and Air-Conditioning Engineers, 1989

P. M. Love, G. E. Courville, eds. Oak Ridge National Laboratory, Oak Ridge, Tenn.

247 Proceedings: 1986 International Daylighting Conference, November 47, 1986, Long Beach, Callfornia

Atlanta: American Society of Heating, Refrigerating, and Air-Conditioning Engineers, 1989

E. Bales, ed. New Jersey Institute of Technology, Newark, N.J.

248 Radon Mitigation In New Construction

Encyclopedia of Architecture: Design, Engineering, and Construction 4, pp. 147-55

(New York: John Wiley \& Sons, Inc., 1989)

J. E. Christian. Oak Ridge National Laboratory, Oak Ridge, Tenn.

249 Techniques for In Situ Determination of Thermal Resistance of Light Welght Board Insulations

J. Heat Trans. 111, pp. 274-80 (1989)

G. E. Courville. Oak Ridge National Laboratory, Oak Ridge, Tenn.

J. V. Beck. Michigan State University, East Lansing, Mich.

250 The International Energy Agency on Low Slope Roofing Systems Int. J. Roofing Technol. 1, pp. 29-31 (1989)

G. E. Courville. Oak Ridge National Laboratory, Oak Ridge, Tenn.

251 Comparison of the Dynamic Thermal Performance of Insulated Roof Systems

Proceedings of the Ninth Conference on Roofing Technology, Gaithersburg, Maryland, May 4-5, 1989, pp. 50-55 (Chicago, III.: National Roofing Contractors Association, 1989) G. E. Courville, P. W. Childs. Oak Ridge National Laboratory, Oak Ridge, Tenn.

P. H. Shipp. USG Corp., Libertyville, III.

T. W. Petrie. Marquette University, Milwaukee, Wis.

252 Final Report of Research and Development of a Dlagnostlc Procedure to Mossure Changes in Thermal Integrity of Bullding Envelopes. Phase II BTR Meter Development ORNL/Sub/83-47959/2 (December 198E)

J. E. Janssen, R. W. Rasmussen. Honey well Coporate Systems Development Division, Golden Valley, Minn. 
253 Structural Thermal Break Systems for Bulldings Heat Transfer Characterlstics of Llghtwelght Structural Concrete Walls

ORNL/Sub/84-21006/3 (December 1988)

M. G. Van Geem. Construction Technology Laboratories, Inc., Skokie, III.

254 Results of Workshop to Develop Alternatives for Insulations Containing CFCs Research Project Menu

ORNL/CON-269 (December 1988)

J. E. Christian, D. L. McElroy. Oak Ridge National Laboratory, Oak Ridge, Tenn.

255 ASTM/DOE Hot BoX Round Robin

ORNL/Sub/84-97333/2 (November 1988)

E. Bales. New Jersey Institute of Technology, Newark, N.J.

256 Feaslbillty Study for Collecting Site Soll Characterlzation Thermal Property Data for Residentlal Construction

ORNL/Sub/86-04923/1 (October 1988)

L. R. Salomone. STS Consultants, Ltd., Fairfax, Va.

257 Heat Loss Through Bullding Envelopes Due to Convectlve Loops K/CSD/TM-80 (October 1988)

J. E. Park, J. R. Kirkpatrick. Martin Marietta Energy Systems, Inc., Oak Ridge, Tenn.

258 A Study of Radiative Heat Transfer Through Foam Insulation ORNL/Sub/86-09099/3 (October 1988)

L. R. Glicksman, M. R. Torpey. Massachusetts Institute of Technology, Cambridge, Mass.

259 Structural Thermal Break Systems for Bulldings. Development and Propertles of Concrete systems

ORNL/Sub/84-21006/2 (October 1988)

A. Litvin, M. G. Van Geem. Construction Technology Laboratories, Skokie, III.

260 Corrosiveness Testing of Thermal Insulating Materlals-A Simulated Field Exposure Study Using a Test Wall

ORNL/Sub/78-7556/4 (September 1988)

K. Sheppard, R. Weil. Stevens Institute of Technology, Hoboken, N.J.

A. Desjarlais. Dynatech Scientific Co., Cambridge, Mass.

261 Assessment of the Thermal and Physical Properties of Masonry Block Products

ORNL/Sub/86-22020/1 (September 1988)

R. Valore, Jr., A. Tuluca, A. Caputo. Steven Winter Associates, Inc., New York, N.Y.

262 Thermal Propertles of Wood and Wood Panel Products for Use In Bulldings

ORNL/Sub/87-21697/1* (September 1988)

A. TenWolde, J. D. McNatt, L. Krahn. U.S. Department of Agriculture, Forest Service, Forest Products Laboratory, Madison, Wis.

263 Steady State Radlative Heat Transfer Through Insulatlons ORNL/Sub/84-89634/1 (August 1988)

P. G. Klemens, N. Kim. University of Connecticut, Storrs, Conn.

"Also available as report no. DOE/USDA-21697/1 from the National Technical Information Service, U.S. Department of Commerce, 5825 Port Royal Road, Springfield, Virginia 22161. 
264 Thermal Res/stance of Wall Cavitles Contalning Reflectlve Insulation ORNL/Sub-7715/6 (August 1988)

B. J. Han. Tennessee Technological University, Cookeville, Tenn.

D. W. Yarbrough. Oak Ridge National Laboratory, Oak Ridge, Tenn.

265 Calculation of Heat Flow and Temperature Flelds for Bullding Envelopes Contalning Thermal Bridges

ORNLM-566 (June 1988)

K. W. Childs. Martin Marietta Energy Systems, Inc., Oak Ridge, Tenn.

266 Analysls of Seven Thermal Bridges Identifled In a Commercial Bullding KJCSD/TM-78 (June 1988)

K. W. Childs. Martin Marietta Energy Systems, Inc., Oak Ridge, Tenn.

267 Bullding Foundation Design Handbook

ORNUSub/86-72143/1 (May 1988)

K. Labs. Undercurrent Design Research, New Haven, Conn.

J. Carmody, R. Sterling, L. Shen. University of Minnesota, Minneapolis, Minn.

Y. J. Huang. Lawrence Berkeley Laboratory, Berkeley, Calif.

D. Parker. Florida Solar Energy Center, Cape Canaveral, Fla.

208 The Impact of Surface Reflectance on the Thermal Performance of Roofs: An Experimental Study

ORNLTM-11699 (April 1988)

E. I. Griggs. Tennessee Technological University, Cookeville, Tenn.

P. H. Shipp. Oak Ridge National Laboratory, Oak Ridge, Tenn.

269 Calculational Model Development for Flbrous Thermal InsulationTranslent Test Procedures

ORNL/Sub/85-27494/1 (February 1988)

J. R. Thomas, Jr. Virginia Polytechnic Institute and State University, Blacksburg, Va.

270 Effect of Surface Mass on Roof Thermal Performance Proceedings of the 5th Annual Symposium on Improving Building Energy Efficiency in Hot and Humid Climates, Houston, September 13-14, 1988, pp. 326-34 (1988)

K. E. Wilkes, J. P. Sanders. Oak Ridge National Laboratory, Oak Ridge, Tenn.

P. H. Shipp. USG Corp., Libertyville, III.

271 Determination of Radiative Propertles of Fiberglass and Foam Insulations ORNL/Sub/86-55930/1 (December 1987)

S. Yajnik, J. A. Roux. University of Mississippi, University, Miss.

272 Bullding Envelope Thermal Anomaly Analysis

ORNL/Sub/85-00294/1 (December 1987)

B. S. Melton, P. Mulroney. VVKR, Inc., Alexandria, Va.

T. Scott. University of Virginia, Charlottesville, $\mathrm{Va}$.

K. W. Childs. Martin Marietta Energy Systems, Inc., Oak Ridge, Tenn.

273 Impact of CFC Restrictions on U.S. Bullding Foundation Thermal

Performance

ORNL/CON-245 (December 1987)

J. E. Christian. Oak Ridge National Laboratory, Oak Ridge, Tenn. 


\section{Assessment of Foam-In-Place Urethane Foam Insulations Used In Bulldings \\ ORNL/Sub/86-56525/1 (October 1987) \\ R. P. Tye. Dynatech Scientific, Inc., Cambridge, Mass.}

275 A Combustion System Seasonal Efflclency Meter-A Prellminary Assessment of a Laboratory Model

ORNL/Sub/85-53142/1 (September 1987)

N. Pearman. Honeywell, Inc., Technology Strategy Center, Golden Valley, Minn.

276 SImulation of the SWTMS Test Cells Using the DOE-2.1A Model ORNL/CON-221 (September 1987)

H. A. McLain, J. E. Christian, S. Y. Ohr, J. L. Bledsoe. Oak Ridge National Laboratory, Oak Ridge, Tenn.

277 Heat Transfer Characterlstics of Insulated Concrete Sandwich Panel Walls ORNL/Sub/79-42539/8 (September 1987)

M. G. Van Geem, S. T. Shirley. Construction Technology Laboratories, Skokie, III.

278 Low-Slope Roofing Research Needs. An ORNL Draft Assessment ORNLM-340 (August 1987)

H. W. Busching. Clemson University, Clemson, S.C.

G. E. Courville. Oak Ridge National Laboratory, Oak Ridge, Tenn.

M. Dvorchak. Mobay Chemical Corp., Pittsburgh, Pa.

J. McCorkle. Consultant to Oak Ridge National Laboratory, Oak Ridge, Tenn.

279 Thickness and Density Measurements for Attlc Loose-Fill Thermal Insulations in Elght Clties

ORNL/TM-10414 (August 1987)

D. W. Yarbrough, R. S. Graves, D. L. McElroy. Oak Ridge National Laboratory, Oak Ridge, Tenn.

280 Uliraviolet Radiatlon Testing of Roofing Systems

ORNL/Sub/85-27453/1 (July 1987)

K. R. Amirkhanian, H. W. Busching. Clemson University, Clemson, S.C.

281 Structural Thermal Break Systems for Bulldings Feaslbillty Study ORNL/Sub/84-21006/1 (March 1987)

S. C. Larson, M. G. Van Geem. Construction Technology Laboratories, Skokie, III.

282 Thermal Mass: A Compar'son of Measurements and Blast Predictlons for Six Test Celis in Two Climates ORNL/Sub/83-70373/2* (January 1987)

W. L. Carroll, A. Mertol, R. Sullivan. Lawrence Berkeley Laboratory, Berkeley, Calif.

\section{Thermal Mass: Blast Residential Parametric Simulations}

ORNL/Sub/83-70373/1 † (January 1987)

W. L. Carroll, R. Sullivan, A. Mertol. Lawrence Berkeley Laboratory, Berkeley, Calif.

"Also available as report no. LBL-18020 from the University of Califomia, Lawrence Berkeley Laboratory, One Cyclotron Road, Berkeley, California 94720.

† Also available as report no. LBL-19681 from the University of Califomia, Lawrence Berkeley Laboratory, One Cyclotron Road, Berkeley, California 94720. 


\section{Inventory of Energy Research In Schools of Archltecture 1972-1985} ORNLSUb/84-89680/1 (January 1987)

D. Prowler, E. Johnson-Mohler, M. Aseltine. University of Pennsylvania, Philadelphia, Pa. 


\section{DISTRICT HEATING}

285 The National Action Plan for District Heating, Cooling and Cogeneration. An Industry-Government Partnership National Planning Committee for District Heating, Cooling and Cogeneration, March 1992*

286 Characterization and Potential of Nonmetallic PIplng Systems for District Heating

ORNLTM-10234 (July 1987)

M. H. Bames. Scantec, Inc., St. Paul, Minn.

M. A. Kamiz, D. J. Naus, J. W. Bryson, Jr. Oak Ridge National Laboratory, Oak Ridge, Tenn.

"Available from M. A. Broders, Oak Ridge National Laboratory, P. O. Box 2008, Oak Ridge TN 37831-6070. 


\section{RESIDENTIAL AND COMMERCIAL CONSERVATION PROGRAM}

287 Direct Installation of Lighting Measures In Small Nonresidentlal Bulldings Procoedings ACEEE 1990 summer Study on Energy Efficiency in Buildingis, Volume 8: Utility Programs, pp. 8.37-8.42 (Washington, D.C.: American Council tor an EnergyEfficient Economy, 1990)

M. B. Gettings, J. M. MacDonald. Oak Ridge National Laboratory, Oak Ridge, Tenn.

288 Life After RCS: Is There a Future for Audit and Other Residential Conservation Programs?

Home Energy 7(3), pp. 24-28 (1990)

R. Vories. Infinite Energy, Denver, Colo.

D. L. White. Oak Ridge National Laboratory, Oak Ridge, Tenn.

289 Expansion of Electric Utility DSM Services to Small Businesses ORNL/CON-293 (September 1989)

M. B. Gettings, J. M. MacDonald. Oak Ridge National Laboratory, Oak Ridge, Tenn.

290 Marketing and Design of Resldentlal Energy Conservation Programs for the Eldarly

ORNL/CON-246 (February 1988)

L. Berry, M. Schweitzer, E. Freeman. Oak Ridge National Laboratory, Oak Ridge, Tenn.

291 Particlpation of the Elderly in Residentlal Conservation Programs Energy Policy 16(2), pp. 152-63 (1988)

L. G. Berry, M. A. Brown. Oak Ridge National Laboratory, Oak Ridge, Tenn.

292 A Revlew of Utllity Conservation Programs for the Commerclal Bullding Sector

ORNLCON-220 (December 1987)

J. O. Kolb, M. S. Hubbard. Oak Ridge National Laboratory, Oak Ridge, Tenn. 


\section{WEATHERIZATION ASSISTANCE PROGRAM}

293 A Status Report on the Natlonal Weatherization Evaluation pp. 7.27-7.29, Proceedings ACEEE 1992 Summer Study on Energy Efficiency in Buildings (Washington, D. C.: American Council for an Energy-Efficient Economy, 1992) M. A. Brown. Oak Ridge National Laboratory, Oak Ridge, Tenn.

D. A. Beschen. U.S. Department of Energy, Office of Energy Efficiency and Renewable Energy, Washington, D. C.

294 Scope of the Weatherization Assistance Program: The Weatherized Population and The Resource Base

ORNL/CON-325 (May 1992)

M. Power, J. F. Eisenberg, E. Michels. Economic Opportunity Research Institute, Washington, D.C.

M. J. Witherspoon. National Association for State Community Senvice Programs, Washington, D. C.

M. A. Brown. Oak Ridge National Laboratory, Oak Ridge, Tenn.

295 Characterlzation of the Weatherization Ass/stance Program Network ORNL/CON-324 (February 1992)

P. E. Mihlmester, W. C. Koehler, Jr., M. A. Beyer. Aspen Systems Conporation, Oak Ridge, Tenn.

M. A. Brown. Oak Ridge National Laboratory, Oak Ridge, Tenn.

D. A. Beschen, Jr. Weatherization Assistance Program, U.S. Department of Energy, Washington, D.C.

296 Experimental Plan for the Fuel-OII Study

ORNL/TM-11668/V2 (January 1992)

M. P. Temes, W. P. Levins, M. A. Brown. Oak Ridge National Laboratory, Oak Ridge, Tenn.

297 Interaction of Heating and Coollng Energy Conservation Envelope Measures with Mechanical System Retrofits

pp. 687-88, Thermal Performance of the Exterior Envelopes of Buildings $V$,

Proceedings of the ASHRAE/DOE/BTECC Conference, December 7-10, 1992,

Cleawater Beach, Florida (Atlanta, Ga.: American Society of Heating, Ventilating, and Air-

Conditioning Engineers, 1992)

M. B. Gettings. Oak Ridge National Laboratory, Oak Ridge, Tenn.

298 Evaluation Plan for the Weatherlzation Assistance Program

ORNL/TM-11668N1 (August 1991)

D. A. Beschen. Weatherization Assistance Program, U.S. Department of Energy,

Washington, D.C.

M. A. Brown. Oak Rid; , National Laboratory, Oak Ridge, Tenn.

299 Experimental Plan for the Single-Family Study

ORNLTM-11668/N3 (September 1991)

L. G. Berry, M. A. Brown, T. Wright, D. L. White. Oak Ridge National Laboratory, Oak

Ridge, Tenn.

300 Assessment of Weatherization Assistance Program Needs for Improved Residentlal Measure Selection Techniques

ORNL/CON-316 (February 1991)

M. B. Gettings, J. O. Kolb. Oak Ridge National Laboratory, Oak Ridge, Terin. 
301 Measuring the Effects of Conservation Program Speclal Services: Cllent Education, Fuel Assistance, and Other Indirect Outcomes

Affordable Comfort V, 5 (Harrisburg: Pennsylvania Energy Otfice, 1991)

D. L. White. Oak Ridge National Laboratory, Oak Ridge, Tenn.

302 The North Carollna Fleld Test: Experimental Plan

ORNL/TM-11339 (August 1990)

T. R. Sharp, M. P. Ternes. Oak Ridge National Laboratory, Oak Ridge, Tenn.

303 Implementation of Blower Door and New Cllent Selection Concepts Into the lowa Weatherlzation Ass/stance Program: Experlmental Plan

ORNL/CON-282 (August 1989)

M. P. Ternes, H. L. Hwang. Oak Ridge National Laboratory, Oak Ridge, Tenn. 


\section{EXISTING BUILDINGS RESEARCH PROGRAM}

304 Research Update, Ex/sting Bulldings Research, 1989-1991

ORNL/CON-333 (February 1993)

J. M. MacDonald, M. P. Temes, W. R. Mixon, T. R. Sharp, J. O. Kolb, K. E. Wikes. Oak Ridge National Laboratory, Oak Ridge, Tenn. R. C. Diamond. Lawrence Berkeley Laboratory, Berkeley, Calfí.

R. Juckoff. National Renewable Energy Laboratory, Golden, Colo.

R. P. Mazzucchi. Pacific Nonthwest Laboratories, Richland, Wash.

305 The Oklahoma Fleld Test: Alr-Conditioning Electriclty Savings from Standard Energy Conservation Measures, Radiant Barrlers, and HighEfficiency Window Alr Conditioners

ORNL/CON-317 (August 1992)

M. P. Temes, W. P. Levins. Oak Ridge National Laboratory, Oak Ridge, Tenn.

306 Modelling Study of the Cooling Season Performance of Exterior Wall Insulation

pp. 655-67, Thermal Pertormance of the Exterior Envelopes of Buildings $V$,

Proceedings of the ASHRAE/DOE/BTECC Conference, Dec.эmber 7-10, 1992, Cleawater Beach, Florida (Atlanta, Ga.: American Society of Heating, Refrigerating, and Air-conditioning Engineers, 1992)

H. A. McLain. Oak Ridge National Laboratory, Oak Ridge, Tenn.

307 Energy Savings and Interactions from Retrofit Measures in Small Commerclal Bulldings In Boston

pp. 31-38, Thermal Performance of the Exterior Envelopes of Buildings V, Proceedings of the ASHRAE/DOE/BTECC Conference, December 7-10, 1992, Clearwater Beach, Florida (Attanta, Ga.: American Society of Heating, Refrigerating, and Air-conditioning Engineers, 1992)

T. R. Sharp, J. M. MacDonald. Oak Ridge National Laboratory, Oak Ridge, Tenn.

308 Monltoring and Evaluation of Foundation Insulation Retrofits In SingleFamlly Detached Houses in St. Paul and Minneapolls, Minnesota. Final Report ORNL/SUb/86-SA711N (October 1991)

M. J. Hewett. Center for Energy and the Urban Environment, Minneapolis, Minn.

G. D. Nelson. Gary Nelson and Associates, Minneapolis, Mirn.

M. T. Noble. Natural Resources Corp., Minneapolis, Minn.

D. A. Robinson. Robinson Technical Services, St. Paul, Minn.

L. S. Shen, L. F. Goldberg. University of Minnesota, Minneapolis, Minn.

309 Monltoring and Evaluation of Replacing Low-Efflclency Alr Conditioners with High-Efficlency Alr Conditloners in Single-Family Detached Houses In Austin, Texas

ORNLSUb/86-SA566/N (August 1991)

R. Bums, R. E. Hough. The Fleming Group, East Syracuse, N.Y.

310 Thermal Model of Attic Systems with Radiant Barriers ORNLCON-262 (July 1991)

K. E. Wikes. Oak Ridge National Laboratory, Oak Ridge, Tenn.

311 Radlant Barrier Attlc Fact Sheet

DOE/CE-0335P, ORNL/M-1937 (June 1991)

K. E. Wikes. Oak Ridge National Laboratory, Oak Ridge, Tenn. 
312 Analysls of Annual Thermal and Molsture Performance of Radlant Barrier Systems

ORNLCON-319 (April 1991)

K. E. Wikes. Oak Ridge National Laboratory, Oak Ridge, Tenn.

313 The National Fuol End-Use Efficlency Fleld Test: Energy Savings and Performance of an Improved Energy Conservation Measure Selection Technlque ORNLCON-303 (March 1991)

M. P. Ternes, P. S. Hu, L S. Williams. Oak Ridge National Laboratory, Oak Ridge, Tenn.

P. Goowey. National Fuel Gas Distribution Corp., Butfab, N.Y.

314 Measured Space-Coollng Electrlclty Savings from Standard Energy Conservation Measures, Radiant Barriers, and High-Efflclency Window Alr Conditioners

Procoedings of the ACEEE 1990 Summer Study on Energy Efficiency in Buildings 9, Pp. 299-308 (Washington, D.C.: American Council for an Energy-Efficient Economy, August 1990)

M. P. Ternes, W. P. Levins. Oak Ridge National Laberatory, Oak Ridge, Tenn.

315 Analysis of Annual Energy Savings Due to Radlant Barrlers Proceodings of the ACEEE 1990 Summer Study on Energy Efficiency in Buildings 1, pp. 235-45 (Washington, D.C.: American Council for an Energy-Efficient Economy, August 1990)

K. E. Wilkes. Oak Ridige National Laboratory, Oak Ridge, Tenn.

316 Masuiurement of Energy Periormance In a Small Bank Bullding ORNL/CON-297 (April 1990)

T. R. Sharp, J. M. MacDonald. Oak Ridge National Laboratory, Oak Ridge, Tenn.

317 Coollng Season Energy Measurements of Dust and Ventllation Effects on Radlant Barrlers ORNLCON-271 (March 1990)

W. P. Levins, M. A. Karnitz. Oak Ridge National Laboratory, Oak Ridge, Tenn.

J. A. Hall. Tennessee Valley Authority, Knoxville, Tenn.

318 Power Generation from Waste IncIneration

Energy Engineering 87(3), pp. 49-62 (1990)

J. O. Kolb, K. E. Wilkes. Oak Ridge National Laboratory, Oak Ridge, Tenn.

319 Energy Savings and Performance of an Improved Energy Efficlency Measure Selection Technlque ASHRAE Transactions 96(Pt. 2) (Allanta, Ga.: American Society of Heating,

Refrigerating, and Air-Conditioning Engineers, 1990)

M. P. Ternes. Oak Ridge National Laboratory, Oak Ridge, Tenn.

320 A Protocol for Monitoring Energy Efficlency Improvements In Commerclal and Related Bulldings

ORNU/CON-291 (September 1989)

J. M. MacDonald, T. R. Sharp, M. B. Gettings. Oak Ridge National Laboratory, Oak Ridge, Tenn. 


\section{Protocols Are Belng Developed to Gulde Bullding Energy Monitoring Projects ASHRAE Joumal 31 (6), p. 38 (June 1989) \\ W. R. Mixon. Oak Rioge National Laboratory, Oak Ridge, Tenn. \\ H. Misuriello. W. S. Fleming Associates, Washington, D.C.}

\section{Tochnology Adoption Strategy for the Existing Bulldings Efficlency Research Program \\ ORNL/CON-286 (June 1989)}

P. E. Mihlmester, J. Gonos, L. Freeman. Applied Management Sciences, Inc., Oak Ridge, Tenn.

M. A. Brown. Oak Ridge National Laboratory, Oak Ridge, Tenn.

323 Investlgation of Metered Data Analysis Mothods for Commercial and Related Bulldings

ORNL/CON-279 (May 1989)

J. M. MacDonald. Oak Ridge National Laboratory, Oak Ridge, Tenn.

D. M. Wasserman. Consultant to Oak Ridge National Laboratory, Oak Ridge, Tenn.

324 Molsture Measurements in Single-Family Houses with Attics Containing Radlant Barrlers

ORNLCON-255 (February 1989)

W. P. Levins, M. A. Karnitz. Oak Ridge National Laboratory, Oak Ridge, Tenn.

J. A. Hall. Tennessee Valley Authority, Chattanooga, Tenn.

325 The Oklahoma Coollng Retroflt Fleld Test: Experimental Plan

ORNLTM-10761 (January 1989)

M. P. Ternes, P. S. Hu. Oak Ridge National Laboratory, Oak Ridge, Tenn.

326 Load Impacts of Energy Managenent Hardware

Proceedings of the End-Use Load Information and Application Conference for Customer and Utility Communication, Syracuse, New York, May 16-17, 1989 (Syracuse, N.Y.: The Fleming Group, 1989)

J. M. MacDonald, T. R. Shanp. Oak Ridge National Laboratory, Oak Ridge, Tenn.

327 The National Fuel Gas End-Use Efficlency Fleld Test: Experimental Plan ORNL/TM-10760 (September 1988)

M. P. Temes, P. S. Hu. Oak Ridge National Laboratory, Oak Ridge, Tenn.

328 Heating Energy Measurements of Single-Family Houses with Attles Containing Radlant Barriers in Comblnation with R-11 and R-30 Celling Insulatlon

ORNL/CON-239 (August 1988)

W. P. Levins, M. A. Karnitz. Oak Ridge National Laboratory, Oak Ridge, Tenn.

329 Research Update: Exlsting Bullding Efflclency Research, 1987-1988 ORNLCON-268 (August 1988)

J. M. MacDonald, M. A. Karnitz, W. R. Mixon. Oak Ridge National Laboratory, Oak Ridge, Tenn.

R. C. Diamond, R. L. Ritschard, M. H. Sherman. Lawrence Berkeley Laboratory, Berkeley, Calif. 
330 Fleld Test Evaluation of Conservation Retroflts of Low-Income SingleFamily Bulldings in Wisconsin: Summary Report

ORNL/CON-228/P1 (July 1988)

M. P. Temes, F. D. Boercker, L. N. McCold, M. B. Gettings. Oak Ridge National

Laboratory, Oak Ridge, Tenn.

331 Radlant Barrler Research Plan

ORNL/CON-256 (June 1988)

K. E. Wilkes, D. W. Yarbrough. Oak Ridge National Laboratory, Oak Ridge, Tenn.

332 Fleld Test Evaluation of Conservation Retroflts of Low-Income, SIngleFamlly Bulldings in Wisconsin: Blower-Door-Directed Inflitration Reduction Procedure, Fleld Test Implementation and Results ORNL/CON-228/P5 (June 1988)

M. B. Gettings, L. N. McCold. Oak Ridge National Laboratory, Oak Ridge, Tenn. J. A. Schlegel. Wisconsin Energy Conservation Corp., Madison, Wis.

333 Fleld Test Evaluation of Conservation Retrofits of Low-Income, SingleFamily Bulldings in Wlsconsin: Audit Fleld Test Implementation and Results ORNL/CON-228/P2 (June 1988)

L. N. McCold. Oak Ridge National Laboratory, Oak Ridge, Tenn.

J. A. Schlegel, L. O'Leary. Wisconsin Energy Conservation Corp., Madison, Wis.

D. C. Hewitt. Portland Energy Office, Portland, Ore.

334 Resources for O/M Training and Services In the Commerclal Bullding Sector ORNLCON-204 (April 1988)

J. O. Kolb. Oak Ridge National Laboratory, Oak Ridge, Tenn.

335 An Analytical Investlgation of Energy End Use In Commerclal Office Bulldings

ORNL/CON-250 (March 1988)

H. A. McLain, J. M. MacDonald, D. J. Downing. Oak Ridge National Laboratory, Oak Ridge, Tenn.

336 Effect of Llfestyle on Energy Use Estlmations and Predicted Savings ORNLCON-241 (March 1988)

T. K. Stovall, L. C. Fuller. Oak Ridge National Laboratory, Oak Ridge, Tenn.

337 Modeling of Residential Attics with Radlant Barriers

Proceodings of the Fifth Annual Symposium on Improving Building Energy Efficiency in Hot and Humid Climates, Houston, Texas, September 13-14, 1988, pp. 161-68 (1988) K. E. Wilkes. Oak Ridge National Laboratory, Oak Ridge, Tenn.

338 An Overview of 3-D Graphical Analysis Using DOE-2 Hourly SImulation Data

ASHRAE Trans 94, pp. 212-27 (Atlanta: American Society of Heating, Refrigerating, and Air-Conditioning Engineers, 1988)

J. S. Haberl. University of Colorado, Boulder, Colo.

J. M. MacDonald. Oak Ridge National Laboratory, Oak Ridge, Tenn.

A. Eden. U.S. Department of Energy, Rocky Flats, Colo. 
339 Management Approaches to Energy Cost Savings in Ex/sting Commerclal Bulldings

ORNLSUb-86/56579/1 (October 1987)

D. G. Bergoust, D. G. Carter, G. A. Jackins, Jr., J. M. Poche, W. A. Rettberg, D. E. Ross, V. Williams, J. M. Bross, E. R. Bajer. American Consulting Engineers Council, Washington,

D.C.

A. J. Willman, P. K. McClure. ACEC Research and Management Foundation,

Washington, D.C.

J. M. MacDonald. Oak Ridge National Laboratory, Oak Ridge, Tenn.

E. C. Freeman, J. Holmes, P. H. Rose. U.S. Department of Energy, Washington, D.C.

340 Estimating Balance Polnt Temperature for Residentlal Bulldings ORNLCON-209 (August 1987)

T. R. Sharp, J. M. MacDonald. Oak Ridge National Laboratory, Oak Ridge, Tenn.

341 Single-Family Bullding Retrofit Performance Monitoring Protocol: Data Speciflcation Guldeline

ORNL/CON-196 (June 1987)

M. P. Ternes. Oak Ridge National Laboratory, Oak Ridge, Tenn.

342 Cooling Energy Measurements of Single-Family Houses with Attics Containing Radiant Barriers In Comblnation with R-11 and R-30 Celling Insulation

ORNL/CON-226 (May 1987)

W. P. Levins, M. A. Karnitz. Oak Ridge National Laboratory, Oak Ridge, Tenn.

343 Fleld Test Evaluation of Conservation Retrofits of Low-Income, SingleFamily Bultelings: Combined Bullding Shell and Heating System Retroflt Audit

ORNL/CON-228/P3 (May 1987)

L. N. McCold. Oak Ridge National Laboratory, Oak Ridge, Tenn.

344 Evaluation of Gas Heating System Retrofit Pllot Programs in Kentucky and Minnesota

ORNL/CON-229 (March 1987)

L. Berry, J. Bledsoe, T. Vineyard, D. L. White. Oak Ridge National Laboratory, Oak Ridge, Tenn.

345 Heating-Energy Measurements of Unoccupled Single-Famlly Houses with Attlcs Containing Radiant Barriers

ORNLCON-213 (January 1987)

W. P. Levins, M. A. Karnitz. Oak Ridge National Laboratory, Oak Ridge, Tenn. 


\section{CERAMIC TECHNOLOGY PROJECT}

346 Apparent Enhanced Fatigue Resistance under Cycllc Tenslle Loading for a HIPed Silicon Nitride

J. Am. Ceram. Soc. 76(3), pp. 788-92 (1993)

M. G. Jenkins, M. K. Ferber. Oak Ridge National Laboratory, Oak Ridge, Tenn.

C.-K. J. Lin. Oak Ridge Institute for Science and Education, Oak Ridge, Tenn.

347 Evaluation of Slalon Internal Combustion Englne Components and Fabrication of Several Ceramic Compon ants for Automotive Applications ORNL/M-22553 (October 1992)

C. H. McMurtry, M. O. Ten Eyck. The Carborundum Company, Niagara Falls, N.Y.

348 Development of Improved Processing Methods for High Rellability Structural Ceramics for Advanced Heat Englnes

ORNLSSUb/89-SD548/1 (July 1992)

A. E. Pasto, S. Natansohn. GTE Laboratories, Inc., Waltham, Mass.

349 Ceramic Technology Project Database: March 1990 Summary Report ORNL/M-1860 (July 1992)

B. L. P. Keyes. Oak Ridge National Laboratory, Oak Ridge, Tenn.

350 Ceramic Technology Project Database: September 1991 Summary Report

ORNL/M-1862 (June 1992)

B. L. P. Keyes. Oak Ridge National Laboratory, Oak Ridge, Tenn.

351 Ceramic Technology Prolect Database: September 1990 Summary Report

ORNL/M-1861 (June 1992)

B. L. P. Keyes. Oak Ridge National Laboratory, Oak Ridge, Tenn.

352 Development of Wear-Reslstant Ceramic Coating for Dlesel Engine Components, Volume 1: Coating Development and Tribological Testing, Final Report

ORNL/Sub/87-SA581/1 (June 1992)

M. G. S. Naylor. Cummins Engine Company, Inc., Columbus, Ind.

353 Development of Ceramic Matrix Composites for Application in the Ceramic Technology for Advanced Heat Engines Project Phase IIA. Development of In-Situ Toughened Sillicon Nitride ORNL/SUb/85-22008/3 (June 1992)

J. Pollinger, D. Newson, H. Yeh, E. Solidum, J. Yamanis, M. Behi, C.-W. Li, P. Whalen. Garrett Ceramic Components Division, Torrance, Calif.

354 Rellablilty Improvements of High Strength Silicon Nitride Through Process Optimization and Control

Proceedings of the Annual Automotive Technology Development Contractors' Coordination Meeting 1991 P.256, pp. 137-44 (Warrendale, Pa.: Society of Automotive Engineers, June 1992)

V. K. Pujari, D. M. Tracey, N. D. Corbin, M. R. Foley, A. K. Garg, N. I. Paille, P. J. Pelletier,

L. C. Sales, C. A. Willkens, R. L. Yeckley. Norton Co., Northboro, Mass. 
355 Life Prediction Methodology of Ceramic Engine Components Proceedings of the Annual Automotive Technology Development Contractors' Coordination Meeting 1991 P-256, pp. 253-59 (Warrendale, Pa.: Society of Automotive Engineers, June 1992)

P. K. Khandelwal, D. L. Vaccari. Allison Gas Turbine Division, General Motors Corp., Indianapolis, Ind.

356 Progress in Life Prediction Methodology for Ceramic Components of Advanced Heat Engines

Proceedings of the Annual Automotive Technology Development Contractors' Coordination Meeting 1991 P-256, pp. 261-72 (Warrendale, Pa.: Society of Automotive Engineers, June 1992) H. T. Fang, J. S. Cuccio, J. C. Wade, K. G. Seybold. Allied-Signal Aerospace Co., Phoenix, Ariz.

M. G. Jenkins. Oak Ridge National Laboratory, Oak Ridge, Tenn.

357 Tenslle Creep Testing of Structural Ceramics Proceedings of the Annual Automotive Technology Development Contractors' Coordination Meeting 1991 P-256, pp. 273-80 (Warrendale, Pa.: Society of Automotive Engineers, June 1992)

S. M. Wiederhorn, R. Krause, D. C. Cranmer. National Institute of Standards and Technology, Gaithersburg, Md.

358 Evaluation of the Elevated-Temperature Mechanical Reliability of a HIPed Sillicon Nitride

Proceedings of the Annual Automotive Technology Development Contractors' Coordination Meeting 1991 P-256, pp. 281-91 (Warrendale, Pa.: Society of Automotive Engineers, June 1992)

M. K. Ferber, M. G. Jenkins. Oak Ridge National Laboratory, Oak Ridge, Tenn.

359 Creep Testing of SNW-1000 Sintered SIIIcon Nitride Proce日dings of the Annual Automotive Technology Development Contractors Coordination Meeting 1991 P-256, pp. 293-305 (Warrendale, Pa.: Sociely of Automotive Engineers, June 1992)

J. Sankar, A. D. Kelkar, R. Vaidyanathan, J. Gao. North Carolina A\&T State University, Greensboro, N.C.

360 Statlstical Procedures for Est/mating Component Strengths and Assoclated Confidence Bounds

Proceedings of the Annual Automotive Technology Development Contractors' Coordination Meeting 1991 P-256, pp. 385-95 (Warrendale, Pa.: Society of Automotive Ëngineers, June 1992)

C. A. Johnson, W. T. Tucker. General Electric Corporate Research and Development, Schenectady, N.Y.

361 Mechanical Testing of Candidate $\mathrm{Si}_{3} \mathrm{~N}_{4}$ Ceramics

Proceedings of the Annual Automotive Technology Development Contractors' Coordination Meeting 1991 P.256, pp. 397-401 (Warrendale, Pa.: Society of Automotive Engineers, June 1992)

N. L. Hecht, S. M. Goodrich, L. Chuck, D. E. McCullum. University of Dayton Research Institute, Dayton, Ohio

362 Wear-Resistant Ceramic Coatings

Proceodings of the Annual Automotive Technology Development Contractors' Coordination Meeting 1991 P-256, pp. 403-15 (Warrendale, Pa.: Society of Automotive Engineers, June 1992)

M. G. S. Naylor. Cummins Engine Co., Inc., Columbus, Ind. 
363 Development of Wear Resistant Ceramic Coatings for Dlesel Engines Proceedings of the Annual Automotive Technology Development Contractors' Coordination Meeting 1991 P.256, pp. 417-24 (Warrendale, Pa.: Society of Automotive Engineers, June 1992)

M. H. Haselkom, F. A. Kelley. Caterpillar, Inc., Peoria, III.

364 The Cost-Effectlve Ceramic Machining Program Plan

Procerdings of the Annual Automotive Technology Development Contractors' Coordination Meoting 1991 P-256, pp. 425-31 (Warrendale, Pa.: Society of Automotive Engineers, June 1992)

P. J. Blau. Oak Ridge National Laboratory, Oak Ridge, Tenn.

365 Nondestructive Evaluation Development for Process Control of Ceramics Proceedings of the Annual Automotive Technology Development Contractors' Coordination Meeting 1991 P-256, pp. 433-37 (Warrendale, Pa.: Society of Automotive Engineers, June 1992)

W. A. Ellingson, D. L. Holloway, E. A. Sivers. Argonne National Laboratory, Argonne, III. J. Ling. Chinese Academy of Sciences.

J. P. Pollinger, H. C. Yeh. Allied Signal Aerospace Co., Torrance, Calif.

366 Development of Uitra-Low-Expansion Ceramics: CMZP and CMZP Matrix Composites

Proceedings of the Annual Automotive Technology Development Contractors' Coordination Meeting 1991 P.256, pp. 145-57 (Warrendale, Pa.: Society of Automotive Engineers, June 1992)

D. A. Hirschfeld, Y. P. Yang, T. K. Li, J. J. Brown. Virginia Polytechnic Institute and State University, Blacksburg, $\mathrm{Va}$.

367 In-Situ Reinforced Sillcon Nitride

Proceedings of the Annual Automotive Technology Development Contractors' Coordination Meeting 1991 P.256, pp. 159-65 (Warrendale, Pa.: Society of Automotive Engineers, June 1992)

H. Yeh, D. Newson, J. Pollinger, E. Solidum. Allied-Signal Aerospace Co., Torrance, Calif.

J. Yamanis, M. Behi, C.-W. Li, P. Whalen. Allied-Signal Corp., Morristown, N. J.

368 Improved Processing of Ceramlc Composites and Cost Effective Sintering of $\mathrm{Si}_{3} \mathrm{~N}_{4}$

Proceedings of the Annual Automotive Technology Development Contractors' Coordination Meeting 1991 P-256, pp. 157-70 (Warrendale, Pa.: Society of Automotive Engineers, June 1992)

D. E. Wittmer, T. E. Paulson, D. Doshi. Southern Illinois University, Carbondale, III.

C. W. Miller, Jr. Centorr Fumaces/Nacuum Industries, Nashua, N. H.

369 Scalabllity Demonstration Program for Sillcon Nitride by the Sullivantm Process for Advanced Ceramics

Proceedings of the Annual Automotive Technology Development Contractors'

Coordination Meeting 1991 P-256, pp. 171-75 (Warrendale, Pa.: Society of

Automotive Engineers, June 1992;

T. M. Sullivan. Sullivan Mining Corp., San Diego, Calif.

370 Development of a High Temperature Hexoloy Sx Sillcon Carbide Proceedings of the Annual Automotive Technology Development Contractors' Coordination Meoting 1991 P-256, pp. 177-81 (Warrendale, Pa.: Society of Automotive Engineers, June 1992)

K. Chia, G. V. Srinivasan, S. K. Lau, R. S. Storm. The Carborundum Company, Niagara Falls, N. Y. 
371 Development of $\mathrm{SI}_{3} \mathrm{~N}_{4}$ in the System $\mathrm{SI}_{3} \mathrm{~N}_{4}-\mathrm{Y}_{2} \mathrm{O}_{3}-\mathrm{SIO}_{2} \cdot \mathrm{MO}_{2} \mathrm{C}$ Proceedings of the Annual Automotive Technology Development Contractors' Coordination Meeting 1991 P-256, pp. 247-51 (Warrendale, Pa.: Society of Automotive Engineers, June 1992)

B. Mikijelj, J. Mangels. Ceradyne, Inc., Costa Mesa, Calif.

372 Tribology of Improved Transformation-Toughened Ceramics-Heat Engine Test. Final Report

ORNL/SUb/90-SG372/1 (April 1992)

E. Lilley, G. A. Rossi, P. J. Pelletier, Norton Company, Northboro, Mass.

373 Materlal Development In the S/3N4 System Using Glass Encapsulated Hip'ing. Final Report, Phase II ORNL/Sub/86-95906/2 (April 1992)

N. D. Corbin, G .J. Sundberg, K. N. Siebein, C. A. Willkens, V. K. Pujari, G. A. Rossi, J. S. Hansen, C. L. Chang, J. L. Hammarstrom. Norton Company, Northboro, Mass.

374 Analytical and Experimental Evaluation of Joining Ceramic Oxides to Ceramic Oxides and Ceramic Oxides to Metal for Advanced Heat Engine Applications. Final Report ORNLSUb/87-SB046/1 (April 1992)

J. Ahman, B. Majumdar, A. R. Rosenfield, S. L. Swartz, J. Cawley, E. Park, D. Hauser, A. T. Hopper. Battelle Columbus Laboratories, Columbus, Ohio

375 Effect of Translucence of Engineering Ceramics on Heat Transfer in Diesel Engines. Final Report.

ORNL/Sub/88-22042/2 (April 1992)

S. Wahiduzzaman, T. Morel. Integral Technologies Inc., Westmont, III.

376 Interference of Wedge-Shaped Protrusions on the Faces of a Griffith Crack In Blaxlal Stress. Final Report ORNL/Sub/87-07685/2 (April 1992)

J. A. M. Boulet. University of Tennessee, Knoxville, Tenn.

377 Development of Low-Expansion Ceramics for Diesel Engine Applications. Final Report

ORNL/Sub/86-22049/1 (April 1992)

J. J. Brown, Jr. Virginia Polytechnic Institute and State University, Blacksburg, Va.

378 Development of Ceramic Matrix Composites for Application In Ceramic Technology for Advanced Heat Engine Program. FInal Report ORNL/Sub/85-22011/2 (April 1992)

S. T. Buljan, J. G. Baldoni, M. L. Huckabee, J. Neil, J. Hefter. GTE Laboratories, Inc., Waltham, Mass.

379 Development of Ceramic Matrix Composites for Application In Ceramic Technology for Advanced Heat Engine Program. Final Report, Phase II ORNLSUb/85-22008/2 (April 1992)

H. Yeh, E. Solidum, K. Karasek, G. Stranford, D. Yuhas, J. Schienle, S. Bradley. Garrett Ceramic Components Division, Allied Signal Aerosf ace Co., Torrance, Calit.

380 Analytical and Experimental Evaluation of Jolning Sillcon Carblde to silicon Carbide and Sillicon Nitride to Silicon Nitride for Heat Engine Applications. Final Report

ORNL/SUb/87-SB045/1 (April 1992)

M. R. Foley, G. A. Rossi, G. J. Sundberg, J. A. Wade, F. J. Wu. Norton Company, Northboro, Mass. 
381 Development of Adherent Ceramic Coatings to Reduce Contact Stress Damage of Ceramics. Final Report

ORNL/Sub/86-95915/1 (April 1992)

C. D'Angelo, H. J. Kim, D. W. Oblas, H. E. Rebenne, V. K. Sarin. GTE Laboratories, Inc., Wattham, Mass.

382 Processing of Sinterable Transformation Toughened Ceramics for Application In Ceramic Technology for Advanced Heat Engines Prolect. Final Report, Phase II

ORNL/Sub/85-22031/2 (April 1992)

E. Lilley, G. A. Rossi. Norton Company, Northboro, Mass.

383 Interference of Wedge-Shaped Protruslons on the Faces of a Grifilth Crack In Blaxlal Stress. Final Report

ORNL/Sub/87-07685/1 (April 1992)

J. A. M. Boulet. University of Tennessee, Knoxville, Tenn.

384 Evaluation of Sillicon Nitride Internal Combustion Engine Components. Final Report

ORNL/SUb/89-SE500/1 (April 1992)

W. Voldrich. Garrett Ceramic Components Division, Torrance, Calif.

385 Studies of Dynamic Contact of Ceramics and Alloys for Advanced Heat Engines. Final Report

ORNL/Sub/84-00216/1 (April 1992)

P. A. Gaydos, K. F. Duirane. Battelle Columbus Division, Columbus, Ohio

386 Engine Testing of Curamic Cam-Roller Followers

ORNLSUb/90-SF985/1 (April 1992)

Y. Kalish. Detroit Diesel Conporation, Detroit, Mich.

387 Development of Wear Resistant Ceramic Coatings for Diesel Engine Components. Final Report

ORNL/SUb/87-SA582/1 (April 1992)

M. H. Haselkom. Caterpillar, Inc., Peoria, III.

388 Relnforcements for HIgh Temperature Ceramics. Final Report ORNL/SUb-90/SB688/1 (April 1992)

C. I. Kyriacou, J. L. Sepulveda, M. A. Watson. Keramont, Tucson, Ariz.

389 Ceramic Technology Project Semlannual Progress Report for April 1991 Through September 1991

ORNLTM-11984 (March 1992)

D. R. Johnson. Oak Ridge National Laboratory, Oak Ridge, Tenn.

390 The Cost of Sillicon Nitride Powder: What Must it Be To Compete? ORNL-6694 (February 1992)

S. Das, T. R. Curlee. Oak Ridge National Laboratory, Oak Ridge, Tenn.

391 A Revlew of Techniques for Jolning Advanced Ceramics

Am. Ceram. Soc. Bull. 71(6), pp. 947-54 (1992)

M. L. Santella. Oak Ridge National Laboratory, Oak Ridge, Tenn. 
392 Pressure Casting Process Control by Uitrasonic Technlque

Ceramic Engineering \& Science Proceedings 13(7), pp. 536-45 (Westerville, Ohio:

American Ceramic Society, 1992)

V. K. Pujari, L. C. Sales. Norton Co., Northboro, Mass.

J. S. Wang, J. Fraser. Precision Acoustics Devices, Inc., Fremont, Calif.

393 Continuous Sintering of $\mathrm{Si}_{3} \mathrm{~N}_{4}$ In a Controlled Atmosphere Belt Furnace Ceramic Engineering \& Science Proceedings 13(7), pp. ث46-61 (Westerville, Ohio:

American Ceramic Society, 1992)

D. E. Wittmer, T. E. Paulson. Southem Illinois University, Carbondale, III.

C. W. Miller, Jr. Centorr Fumaces/Nacuum Industries, Nashua, N. H.

\section{Twisting and Friction Errors In Flexure Testing}

Ceramic Engineering \& Science Proceedings 13(7), pp. 319-30 (Westerville, Ohio:

American Ceramic Society, 1992)

G. D. Quinn. National Institute of Standards and Technology, Gaithersburg, Md.

395 Ceramic-Metal Jolnts Brazed with Palladium Alloys

J. Am. Welding Soc. 71(1), pp. 25s-35s (1992)

J. H. Selverian, S. Kang. GTE Laboratories, Inc., Wattham, Mass.

396 The Role of Ion Specles on the Adhesion Enhancement of Ion Eesm Mixed $\mathrm{Fe}_{\mathrm{A}} \mathrm{Al}_{2} \mathrm{O}_{3}$ Systems

Proceedings of the Fall Meeting of the Materials Research Society, Boston, December 26, 1991 238, pp. 793-98 (Pittsburgh, Pa.: Materials Research Society, 1992)

J. E. Pawel, C. J. McHargue, L. J. Romana, L. L. Horton, J. J. Wert. Oak Ridge National Laboratory, Oak Ridge, Tenn.

397 Ion Beam Enhanced Adhesion of Iron Fllms to Sapphire Substrates Surf. Coatings Technol. 51, pp. 129-32 (1992)

J. E. Pawel, C. J. McHargue, L. J. Romana, J. J. Wert. Oak Ridge National Laboratory, Oak Ridge, Tenn.

398 Study and Analysls of the Stress State In a Ceramic, Button-Head, Tenslle Specimen

ORNL/TM-11767 (September 1991)

M. G. Jenkins, M. K. Ferber, R. L. Martin, V. T. Jenkins, V. J. Tennery. Oak Ridge National Laboratory, Oak Ridge, Tenn.

399 Report on the Planning Workshop on Cost-Effectlve Ceramic Machining ORNL/M-1745 (November 1991)

P. J. Blau. Oak Ridge National Laboratory, Oak Ridge, Tenn.

400 Ceramic Technology for Advanced Heat Engines Prolect Semlannual Progress Report for October 1990 Through March 1991

ORNLTM-11859 (July 1991)

D. R. Johnson. Oak Ridge National Laboratory, Oak Ridge, Tenn.

401 Gelcasting-A New Ceramic Forming Process

Am. Ceram. Soc. Bull. 70(1), pp. 1641-49 (1991)

O. O. Omatete, M. A. Janney, R. A. Strehlow. Oak Ridge National Laboratory, Oak Ridge, Tenn.

402 High Temperature Degradation of Structural Composites Ceram. Int. 17, pp. 243-52 (1991)

S. M. Wiederhorn, B. J. Hockey. National Institute of Standards and Technology,

Gaithersburg, Md. 
403 Microstructural Characterlzation of Creep-Deformed sic WhiskerReinforced $\mathrm{Sl}_{3} \mathrm{~N}_{4}$ Composite

Ultramicroscopy 37, p. 263 (1991)

K. L. More. Oak Ridge National Laboratory, Oak Ridge, Tenn.

D. A. Koester, R. F. Davis. North Carolina State University, Raleigh, N. C.

404 Deformation and Mlcrostructural Changes in SiC Whisker-Reinforced $\mathrm{SI}_{3} \mathrm{~N}_{4}$ Composites

J. Mater. Res. 6(12), p. 2735 (1991)

D. A. Koester, R. F. Davis. North Carolina State University, Raleigh, N. C.

K. L. More. Oak Ridge National Laboratory, Oak Ridge, Tenn.

405 Defect Characterlzation In a CVD $\alpha \mathrm{SI}_{3} \mathrm{~N}_{4}$

Procoedings of the 49th Annual Meeting of the Electron Microscopy Society of Amorica, ed. G. W. Bailey, pp. 936-37 (San Francisco: San Francisco Press, 1991)

K. L. More. Oak Ridge National Laboratory, Oak Ridge, Tenn.

406 Ceramic Technology for Advanced Heat Engines Project Semiannual Progress Report for Aprll 1990 Through September 1990

ORNLTM-11719 (December 1990)

D. R. Johnson. Oak Ridge National Laboratory, Oak Ridge, Tenn.

407 Coramic Technology for Advanced Heat Engines Project Database:

September 1989 Summary Report

ORNL/M-1286 (October 1990)

B. L. P. Keyes. Oak Ridge National Laboratory, Oak Ridge, Tenn.

408 Mechanical Behavior of a SiC-Fiber/SI3 ${ }_{3} N_{4}$ Composite

MTL TN 90-2* (September 1990)

J. J. Swab, G. D. Quin, D. J. Snoha. U.S. Army Materials Technology Laboratory,

Watertown, Mass.

409 The Evaluation of Environmental Effects in Toughened Ceramics for Advanced Heat Engines Investigation of Selected SIC and $\mathrm{SI}_{3} \mathrm{~N}_{4}$ Coramics

ORNL/Sub/84-00221/2 (August 1990)

N. L. Hecht, G. A. Graves, D. E. McCullum, A. P. Berens, S. Goodrich, J. D. Wolf, J. R. Hoenigman, P. Yaney, D. Grant, S. Hilton. University of Dayton Research Center, Dayton, Ohio

410 Synthesls of High Purlty Sinterable $\mathrm{SI}_{3} \mathrm{~N}_{4}$ Powders

ORNL/Sub/85-SB012/1 (August 1990)

G. M. Crosbie, R. L. Predmesky, J. M. Nicholson. Ford Motor Co., Dearbom, Mich.

411 Ceramlc Technology for Advanced Heat Engines Project. Semiannual Progress Report for Aprll 1989 Through September 1989 ORNL/TM-11489 (August 1990)

D. R. Johnson. Oak Ridge National Laboratory, Oak Ridge, Tenn.

412 Influence of Dlesel Engine Exposure on the Rupture Strength of Sillcon Nitride and Partially Stabilized Zirconla

ORNL-6612 (June 1990)

C. R. Brinkman, G. M. Begun, R. L. Graves, W. K. Kahl, K. C. Liu, B. H. West. Oak Ridge National Laboratory, Oak Ridge, Tenn.

"Available from the U.S. Amry Materials Technology Laboratory, Watertown, Mass. 02172-0001. 
413 Effect of Environment upon Mechanical Behavlor of Structural Ceramics for Application in the DOE Ceramic Technology for Advanced Heat Engines Project. Final Report, January 1985 December 1986 ORNL/Sub/84-00221/1 (June 1990)

N. L. Hecht, G. A. Graves, D. E. Mc ¿ullum, A. P. Berens, S. Goodrich, J. D. Wolf, J. R. Hoenigman, P. Yaney, D. Grant, S. rithon, S. D. Jang. University of Dayton Research Institute, Dayton, Ohio

414 Analytical and Experimuntal Evaluation of Joining Sillicon Nitride to Metal and sillicon Carblde to Metal for Advanced Heat Engine Applications.

Final Report Phase I

ORNUSUb/87-SBO47C/1 (April 1990)

S. Kang, J. H. Selverian, H. Kim, D. O'Niel. GTE Laboratories, Inc., Waltham, Mass.

K. Kim. Brown University, Providence, R.I.

415 Ceramic Technology for Advanced Heat Englnes Project Data Base: March 1989 Summary Report ORNLM-1098 (April 1990)

B. L. P. Keyes. Oak Ridge National Laboratory, Oak Ridge, Tenn.

416 Development of Wear-Resistant Ceramic Coatings for Diesel Engine Components

Proceedings of the Twenty-Seventh Automotive Technology Development Contractors' Coordination Meeting P-230, pp. 131-41 (Warrendale, Pa.: Society of Automotive Engineers, Inc., April 1990)

M. G. S. Naybr, M. P. Fear. Cummins Engine Company, Inc., Columbus, Ind.

417 Wear-Resistant Ceramic Coatings for Diesel Englne Components Proceodings of the Twenty-Seventh Automotive Technology Development Contractors' Coordination Meeting P-230, pp. 143-48 (Warrendale, Pa.: Society of Automotive Engineers, Inc., April 1990)

M. H. Hasekom, F. A. Kelley, C. D. Weiss. Caterpillar, Inc., Peoria, III.

418 Studies of Dynamic Contact of Ceramics and Alloys for Advanced Heat Englnes

Proceedings of the Twenty-Seventh Automotive Technology Development Contractors' Coordination Meeting P-230, pp. 149-53 (Warrendale, Pa.: Society of Automotive Engineers, Inc., April 1990)

P. A. Gaydos, K. F. Disfrane. Battelle Columbus Laboratories, Columbus, Ohio

419 Identification and Development of Optimum Sillcon Carblde Whiskers for silicon Nitride Matrix Composites

Proceedings of the Twenty-Seventh Automotive Technology Development Contractors' Coordination Meeting P-230, pp. 167-72 (Warrendale, Pa.: Society of Automotive Engineers, Inc., April 1990)

T. N. Tiegs, L. F. Allard, P. F. Becher, M. K. Ferber. Oak Ridge National Laboratory, Oak Ridge, Tenn.

420 Synthesls of High-Purity Sinterable Sillicon Nitride Powder Proceedings of the Twenty-Seventh Automotive Technology Development Contractors' Coordination Meeting P-230, pp. 191-96 (Warrendale, Pa.: Society of Automotive Engineers, Inc., April 1990)

G. M. Crosbie, R. L. Predmesky, J. M. Nicholson. Ford Motcrir Co., Dearbom, Mich. 
421 Advanced Processing of High-Performance Sillcon Nitride Ceramics Proceodings of the Twenty-Seventh Automotive Technology Development Contractors' Coordination Meeting P-230, pp. 197-206 (Warrendale, Pa.: Society of Automotive Engineers, Inc., April 1990)

A. E. Pasto, S. Natansohn. GTE Laboratories, Inc., Waltham, Mass.

422 Materlal Development in the Silicon Nitride-Silicon Carblde Whisker System

Proceodings of the Twenty-Seventh Automotive Technology Development Contractors' Coordination Meeting P-230, pp. 207-13 (Warrendale, Pa.: Society of Automotive Engineers, Inc., April 1990)

N. D. Corbin, K. N. Siebein, J. S. Hansen, G. J. Sundberg, V. K. Pujari, G. A. Rossi. Norton Co., Northborough, Mass.

423 Mechanical Propertles Characterlzation of High Performance Ceramics Proceedings of the Twenty-Seventh Automotive Technology Development Contractors' Coordination Meeting P-230, pp. 217-33 (Warrendale, Pa.: Society of Automotive Engineers, Inc., April 1990)

N. L. Hecht, D. E. McCullum, S. Goodrich, L. Chuck. University of Dayton Research Institute, Dayton, Ohio

424 High Temperature Tenslle and Fatigue Strengths of Sillcon Nitride Proceodings of the Twenty-Seventh Automotive Technology Development Contractors' Coordination Meeting P-230, pp. 235-44 (Warrendale, Pa.: Society of Automotive Engineers, Inc., April 1990)

K. C. Liu, C. R. Brinkman. Oak Ridge National Laboratory, Oak Ridge, Tenn.

425 Numerical and Emplrical Verlfication of the Stress State In a Ceramic, Button-head, Tensile Specimen

Procoodings of the Twenty-Seventh Automotive Technology Development Contractors' Coordination Meeting P-230, pp. 245-50 (Warrendale, Pa.: Society of Automotive Engineers, Inc., April 1990)

M. G. Jenkins, M. K. Ferber, R. L. Martin, V. J. Tennery. Oak Ridge National Laboratory, Oak Ridge, Tenn.

426 Tenslle Creep of SiC Whisker Reinforced Sillicon Nitrlde

Proceedings of the Twenty-Seventh Automotive Technology Development Contractors' Coordination Meeting P-230, pp. 251-64 (Warrendale, Pa.: Society of Automotive Engineers, Inc., April 1990)

B. J. Hockey, S. M. Wiederhorn, W. Liu. National Institute of Standards and Technology, Gaithersburg, Md.

J. G. Baldoni, S.-T. Buljan. GTE Laboratories, Inc., Waltham, Mass.

427 Fracture Strength Analysis of Sillcon Nitride and Sillcon Carbide Ceramics from an International Cooperative Research Program Proceedings of the Twenty-Seventh Automotive Technology Development Contractors' Coordination Meeting P.230, pp. 265-73 (Warrendale, Pa.: Society of Automotive Engineers, Inc., April 1990)

V. J. Tennery, M. K. Ferber. Oak Ridge National Laboratory, Oak Ridge, Tenn.

428 Life Prediction Methodology for Ceramic Components of Advanced Heat Englnes

Proceedings of the Twenty-Seventh Automotive Technology Development Contractors' Coordination Meeting P-230, pp. 275-82 (Warrendale, Pa.: Society of Automotive Engineers, Inc., April 1990)

A. M. Comfort, J. S. Cuccio. Garrett Auxiliary Power Div., Allied-Signal Aerospace Co., Phoenix, Ariz. 
429 Low Temperature Degradation of Y-TZP Materlals

MTL TR 90-4* (January 1990)

J. J. Swab. U.S. Army Materials Technology Laboratory, Watertown, Mass.

430 Performance of Y-TZP Materlals Between $800^{\circ} \mathrm{C}$ and $1200^{\circ} \mathrm{C}$

MTL TR 90-3* (January 1990)

J. J. Swab. U.S. Army Materials Technology Laboratory, Watertown, Mass.

431 Elevated-Temperature-Delayed Fallure of Alumina Relnforced With 20 Vol \% Sillicon Carblde Whiskers

J. Mater. Sci. 73, pp. 91-96 (1990)

P. F. Becher, P. Angelini, W. H. Warwick, T. N. Tiegs. Oak Ridge National Laboratory, Oak Ridge, Tenn.

432 A New Method for Analyzing Data from Continuous Depth-Sensing Microlndentation Tests

J. Mater. Res. 5, pp. 123-26 (1990)

D. L. Joslin. University of Tennessee, Knoxville, Tenn.

W. C. Oliver. Oak Ridge National Laboratory, Oak Ridge, Tenn.

433 Thermal Diffuslvity/Conductlvity of Alumina-SIllcon Carbide

J. Am. Ceram. Soc. 73, pp. $461-64$ (1990)

P. H. McCluskey. Alfred University, Alfred, N.Y.

R. K. Williams, R. S. Graves, T. N. Tiegs. Oak Ridge National Laboratory, Oak Ridge,

Tenn.

434 Effect of Aspect Ratio and Liquid Phase Content on Densification of Alumina-SIC Whisker Composites

J. Am. Ceram. Soc. 73(5), pp. 1440-42 (1990)

T. N. Tiegs. Oak Ridge National Laboratory, Oak Ridge, Tenn.

D. M. Dillard. Georgia Institute of Technology, Atlanta, Ga.

435 Creep Behavior of an SIC-Whisker-Relnforced Alumina

J. Am. Ceram. Soc. 73, pp. 1378-81 (1990)

H. T. Lin, P. F. Becher. Oak Ridge National Laboratory, Oak Ridge, Tenn.

436 The Role of Interfaces In the Creep-Deformation of an SIC WhiskerReinforced $\mathrm{SI}_{3} \mathrm{~N}_{4}$ Composite

Proceedings of the Twelfth International Congress for Electron Microscopy, Seattle, August 12-18, 1990, pp. 382-83 (San Francisco: San Francisco Press, Ins., 1990)

K. L. More. Oak Ridge National Laboratory, Oak Ridge, Tenn.

D. A. Koester, R. F. Davis. North Carolina State University, Raleigh, N.C.

437 Synthesis of High Purlty SInterable Sillicon Carblde Powder ORNL/Sub/84-00214/1 (November 1989)

W. D. Boecker, B. L. Mehosky, R. S. C. Rogers, R. S. Stom, V. Venkateswaran. The Carbonundum Company, Structural Ceramics Division, Niagara Falls, N.Y.

438 Ceramic Technology for Advanced Heat Englnes Project Semlannual Progress Report for October 1988 Through March 1989

ORNL/TM-11239 (August 1989)

D. R. Johnson. Oak Ridge National Laboratory, Oak Ridge, Tenn.

- Available from the U.S. Amy Materials Technology Laboratory, Watertown, Mass. 02172-0001. 


\section{IEA/Annex II Powder Characterlzation Cooperative Program \\ MTL TR 89-53* (June 1989)}

T. M. Resetar, J. W. McCauley. U.S. Army Materials Technology Laboratory, Watertown, Mass.

G. E. Schaefer. W. R. Grace Company, Cambridge, Mass.

A. L. Dragoo, S. M. Hsu. National Institute of Standards and Technology, Gaithersburg, Md.

D. R. Johnson. Oak Ridge National Laboratory, Oak Ridge, Tenn.

H. Hausner. Technical University of Berlin, Berlin, FRG

R. Pompe. Swedish Institute for Silicate Research, Gớteborg, Sweden

440 LIfe Prediction Methodology for Ceramic Components Procesdings of the 26th Automotive Technology Development Contractors' Cuordination Meeting, Dearborn, Michigan, October 24-27, 1988, pp. 257-62

(Warrendale, Pa.: Society of Automotiv': Engineers, Inc., April 1989)

D. L. Vaccari, P. K. Khandehwal. Allison Gas Turbine Div., General Motors Corp., Indianapolis, Ind.

441 Development of Sllicon Carblde Whisker Reinforced sillcon Nitride Formod by Silp Casting

Proceedings of the 26th Automotive Technology Development Contractors'

Coordination Meeting, Dearborn, Michigan, October 24-27, 1988, pp. 251-55

(Warrendale, Pa.: Society of Automotive Engineers, Inc., April 1989)

H. C. Yeh. Garrett Ceramic Components Division, Torrance, Calif.

J. L. Schienle. Garrett Auxiliary Power Div., Phoenix, Ariz.

K. R. Karasek, S. A. Bradley. Allied-Signal Engineered Materials Research Center, Des Plaines, III.

442 Sillcon Carblde Whisker Relnforced Sillcon Nitride

Proceedings of the 26th Automotive Technology Development Contractors'

Coordination Meeting, Dearborn, Michigan, October 24-27, 1988, pp. 243-50

(Warrendale, Pa.: Society of Automotive Engineers, Inc., April 1989)

M. L. Huckabee, J. G. Baldoni, J. T. Neil, G. Zilberstein, S.-T. Buljan. GTE Laboratories, Inc., Waltham, Mass.

443 Materlal Development in the Sillcon Nitride-Sillcon Carbide Whisker Systom

Proceedings of the 26th Automotive Technology Development Contractors'

Coordination Meeting, Dearborn, Michigan, October 24-27, 1988, pp. 235-41

(Warrendale, Pa.: Society of Automotive Engineers, Inc., April 1989)

N. D. Corbin, C. A. Willkens, J. L. Hammarstrom, V. K. Pujari, G. A. Rossi, K. N. Siebein.

Norton Co., Northboro, Mass.

J. S. Hansen, C. L. Chang. Norton Co., Salt Lake City, Utah

444 Development of Improved Processing and Evaluation of sillcon Nitride Proceedings of the 26th Automotive Technology Development Contractors'

Coordination Meeting, Dearborn, Michigan, October 24-27, 1988, pp. 227-34

(Warrendale, Pa.: Society of Automotive Engineers, Inc., April 1989)

V. K. Pujari, K. E. Amin, P. H. Tewari, S. D. Hartline. Norton Co., Northboro, Mass.

\footnotetext{
- Ávailathe from the U.S. Ammy máateriais Techiñoiogy Laboraiong, Wuateriown, Mass. 02172-00001.
} 


\section{Ceramic Coatings to Reduce Contact Stress Damage of Ceramics} Performance Tosting

Proceedings of the 26th Automotive Technology Development Contractors' Coordination Meeting, Dearborn, Michigan, October 24-27, 1988, pp. 221-26 (Warrendale, Pa.: Society of Automotive Engineers, Inc., April 1989) D. W. Oblas, C. D'Angelo, H. E. Rebenne, V. K. Sarin. GTE Laboratories, Inc., Waltham, Mass.

446 Dynamlc Contact of Coramics in Ring-Cylinder Applications Proceedings of the 26th Automntive Technology Development Contractors' Coordination Meeting, Dearborn, Michigan, October 24-27, 1988, pp. 145-48 (Warrendale, Pa.: Society of Automotive Engineers. Inc., April 1989) K. F. Dutrane, P. A. Gaydos. Battelle Columbus Div., Columbus, Ohio

447 Wear Resistant Ceramic Coatings for Dlesel Englne Components Proceedings of the 26th Automotive Technology Development Contractors' Coordination Meeting, Dearborn, Michigan, October 24-27, 1988, pp. 119-22 (Warrendale, Pa.: Society of Automotive Engineers, Inc., April 1989) M. Haselkom, F. Kelley, D. Weiss. Caterpillar, Inc., Peoria, III.

448 Development of Magnetic Resonance Imaging Technology for Imaging Binder Distribution in Ceramics Proceodings of the 26th Automotive Technology Development Contractors' Coordination Meeting, Dearborn, Michigan, October 24-27, 1988, pp. 211-17 (Warrendale, Pa.: Society of Automotive Engineers, Inc., April 1989) W. A. Ellingson, P. S. Wong. Argonne National Laboratory, Argonne, III. J. L. Ackerman. Massachusetts General Hospital, Boston, Mass. H. C. Yeh, J. P. Pollinger. Allied-Signal Aerospace Co., Torrance, Calif.

449 Confidence Bounds on Strength Estlmates Procoedings of the 26th Automotive Technology Development Contractors' Coordination Meeting, Dearborn, Michigar, October 24-27, 1988, pp. 205-10 (Warrendale, Pa.: Society of Automotive Engineers, Inc., April 1989) W. T. Tucker, C. A. Johnson. GE Corporate R\&D, Schenectady, N.Y.

450 Synthesls and Characterization of Uitra-Low Thermal Expansion Oxide Coramics Proceedings of the 26th Automotive Technology Development Contractors' Coordination Meeting, Dearbom, Michigan, October 24-27, 1988, pp. 187-204 (Warrendale, Pa.: Society of Automotive Engineers, Inc., April 1989) R. E. Swanson, J. J. Brown. Virginia Polytechnic Institute and State University, Blacksburg, Va.

451 Strength and Fatigue of Sillicon Nitride In Uniaxial Tension Proceodings of the 26th Automotive Technology Development Contractors' Coordination Meeting, Deartorn, Michigan, October 24-27, 1988, pp. 173-86 (Warrendale, Pa.: Society of Automotive Engineers, Inc., April 1989) J. Sankar, A. Kelkar, A. Sinha. North Carolina A\&T State University, Greensboro, N.C. K. C. Liu. Oak Ridge National Laboratory, Oak Ridge, Tenn. 
452 Analytical and Experimental Evaluation of Jolning Sillcon Nitride to Metal and sillicon Carblde to Metal

Proceodings of the 26th Automotive Technology Development Contractors'

Coordination Meeting, Deartorn, Michigan, October 24-27, 1988, pp. 165-71

(Warrendale, Pa.: Society of Automotive Engineers, Inc., April 1989)

E. M. Dunn, S. Kang. GTE Laboratories, Inc., Waltham, Mass.

H. Mizuhara. Wesgo Div., GTE Products Corp., Belmont, Calif.

K. S. Kim. University of Illinois, Urbana, III.

453 Analytical and Experimental Evaluation of Jolning Sillicon Carblde to sillcon Carblde and Sillicon Nitride to Sillicon Nitride for Advanced Heat Engliro Appllcations

Proceodings of the 26th Automotive Technology Development Contractors' Coordination Meeting, Dearborn, Michigan, October 24-27, 1988, pp. 157-63

(Warrendale, Pa.: Society of Automotive Engineers, Inc., April 1989)

G. A. Rossi, D. O. Patten, G. J. Sundberg, C. H. Bates, F. J. Wu. Norton Co., Northboro, Mass.

454 Jolning of Zirconla Ceramics with a CaO-TiO2-SiOn Interlayer Proceedings of the 26th Automotive Technology Development Contractors' Coordination Meeting, Dearborn, Michigan, October 24-27, 1988, pp. 149-54 (Warrendale, Pa.: Society of Automotive Engineers, Inc., April 1989)

S. L. Swartz, B. S. Majumdar, B. C. Mutsuddy. Battelle Columbus Div., Columbus, Ohio

455 Zirconla Toughened Ceramics for Heat Engine Appllcations Phase IIA Proceedings of the 26th Automotive Technology Development Contractors' Coordination Meeting, Dearborn, Michigan, October 24-27, 1988, pp. 133-44 (Warrendale, Pa.: Society of Automotive Engineers, Inc., April 1989) E. Lilley, G. A. Rossi. Norton Co., Northboro, Mass.

456 Influence of Dlesel Englne Combustion on the Rupture Strength of Partlally Stablilzed Zirconla Proceodings of the 26th Automotive Technology Development Contractors' Coordination Meeting, Dearborn, Michigan, October 24-27, 1988, pp. 123-31

(Warrendale, Pa.: Society of Automotive Engineers, Inc., April 1989)

C. R. Brinkman, G. M. Begun, O. B. Cavin, B. E. Foster, R. L. Graves, W. K. Kahl, K. C. Liu, W. A. Simpson. Oak Ridge National Laboratory, Oak Ridge, Tenn.

457 Development of Wear-Res/stant Ceramic Coatings for Advanced Diesel Englnes

Proceedings of the 26th Automotive Technology Development Contractors' Coordination Meeting, Dearborn, Michigan, October 24-27, 1988, pp. 111-18 (Warrendale, Pa.: Society of Automotive Engineers, Inc., April 1989) M. G. S. Naybr, M. P. Fear. Cummins Engine Co., Inc., Columbus, Ind.

458 Ceramic Technology for Advanced Heat Englnes Project Semiannual Progress Report for Aprll Through September 1988 ORNLTM-11116 (March 1989)

D. R. Johnson. Oak Ridge National Laboratory, Oak Ridge, Tenn.

459 Properties of Vttrla-Tetragonal Zirconia Polycrystal (V-TZP) Materials After Long-Term Exposure to Elevated Temperatures MTL TR 89-21* (March 1989)

J. J. Swab. U.S. Amy Materials Technology Laboratory, Watertown, Mass.

- Available from the U.S. Amy Materials Technology Laboratory, Watertown, Mass. 02172-0001. 
460 Ceramic Technology for Advanced Heat Englnes Project Data Base: September 1988 Summary Report ORNLM-755 (March 1989)

B. L. P. Booker. Oak Ridge National Laboratory, Oak Ridge, Tenn.

461 Thin Film and Near Surface Characterlzation Using Indentation Systems Proceedings NATO Advanced Study Institute on Structure-Property Relationships in Surface-Modified Ceramics, Ciocco, Italy, August 28-September 9, 1988, pp. 295-302 (Boston; Dordrecht, The Netherlands: Klüwer Academic Publishers, 1989) D. L. Joslin. University of Tennessee, Knoxville, Tenn. C. J. McHargue, W. C. Oliver. Oak Ridge National Laboratory, Oak Ridge, Ternn.

462 Exploratory High-Temperature Tenslle and Cycllc Fatigue Characterlzation of Commerclal MgO-PSZ Proceodings Third International Symposium on Ceramic Materials and Components, Las Vegas, November 27-30, 1988, pp. 841-55 (Westerville, Ohio: American Ceramic Society, 1989)

K. C. Liu, C. R. Brinkman. Oak Ridge National Laboratory, Oak Ridge, Tenn.

463 Pre-PIlot Synthes/s of Low Carbon $\mathrm{Sl}_{3} \mathrm{~N}_{4}$

Proceodings Second International Conference on Ceramic Powder Processing Science, Berchtesgaden, FRG, October 12-14, 1988, pp. 269-73 (Bad Honnef: Deutsche Keramische Gesellschaft, 1989)

G. M. Crosbie, J. M. Nicholson, R. L. Predmesky, E. D. Stiles. Ford Motor Company, Dearborn, Mich.

464 Laser Diffraction Methods for High Temperature Sirain Measurements Proceodings Spring Conference on Experimental Mechanics, Cambridge, Mass., May 28 June 2, 1989, pp. 87-93 (Society of Experimental Mechanics, 1989)

H. Pih. University of Tennessee, Knoxville, Tenn.

K. C. Liu. Oak Ridge National Laboratory, Oak Ridge, Tenn.

465 Theoretical and Experimental Analysls of the Toughening Behavlor of Whisker Relnforcement In Ceramic Matrix Composites Mater. Sci. Eng. A107, pp. 257-59 (1989)

P. F. Becher, C. H. Hsueh, P. Angelini, T. N. Tiegs. Oak Ridge National Laboratory, Oak Ridge, Tenn.

466 Ceramic Technology for Advanced Heat Englnes Project Semiannual Progress Report for October 1987 Through March 1988 ORNLTM-10838 (December 1988)

D. R. Johnson. Oak Ridge National Laboratory, Oak Ridge, Tenn.

467 Influence of Dlesel Englne Combustion on the Rupture Strength of Partlally Stablized Zirconla

ORNL-6513 (December 1988)

C. R. Brinkman, G. M. Begun, O. B. Cavin, B. E. Foster, R. L. Graves, W. K. Kahl, K. C. Liu, W. A. Simpson. Oak Ridge National Laboratory, Oak Ridge, Tenn.

468 Brazing Ceramic Oxides to Metals at Low Temperatures Weld. J., pp. 227s-32s (October 1988)

J. P. Hammond, S. A. David, M. L. Santella. Oak Ridge National Laboratory, Oak Ridge, Tenn.

469 Dispersold-Toughened Silicon Nitride Composites ORNL/SUb/85-22011/1 (September 1988)

S.-T. Buljan, J. G. Baldoni, J. Neil, G. Zilberstein. GTE Laboratories, Inc., Wattham, Mass. 
470 Processing of Sinterable Transformation Toughened Ceramics for Application In Ceramic Technology for Advanced Heat Engines Project. Final Report

ORNL/SUb/85-22031/1 (September 1988)

G. A. Rossi, J. B. Blum, C. E. Knapp, K. E. Manwiller. Norton Co., Northboro, Mass.

471 Development of Toughened $\mathrm{S}_{3} \mathrm{~N}_{4}$ Composites by Glass Encapsulated Hot Isostatlc Pressure. Final Report

ORNL/Sub/86-95906/1 (August 1988)

N. D. Corbin, C. A. Willkens. Norton Co., Northboro, Mass.

472 Transformation-Toughened Silicon Nitrlde. Final Report ORNL/SUb/85-22009/1 (August 1988)

H. W. Carpenter. Rockwell International, Rockedyne Division, Canoga Park, Calit.

473 Processing and Characterization of Transformation-Toughened Ceramics with Strength Retention to Elevated Temperatures. Final Report ORNL/Sub/85-22028/1 (July 1988)

R. A. Cutler, J. J. Hansen, D. W. Prouse, J. D. Bright. Ceramatec, Inc., Salt Lake City, Utah A. V. Virkar, D. K. Shetty. University of Utah, Salt Lake City, Utah

474 TIme-Dependent Mechanical Behavior of Partially Stabillzed Zirconla for Dlesel Engine Applications

ORNLSUb/85-27416/1 (July 1988)

M. K. Ferber. Oak Ridge National Laboratory, Oak Ridge, Tenn.

T. Hine. University of Illinois Uibana-Champaign, Urbana, III.

475 Analysls of Adheslon Test Methods and the Evaluatlon of Their Use for Ion-beam-mixed Metal/Ceramic Systems

ORNLTM-10468 (July 1988)

J. E. Pawel. Vanderbilt University, Nashville, Tenn.

476 Development of Ceramic Matrix Composites for Appllcation in the Ceramic Technology for Advanced Heat Engines, Final Report ORNL/Sub/85-22008/1 (June 1988)

H. Yeh, J. Schienle, K. Karasek, S. Bradley. Garrett Ceramic Components Division, Torrance, Calif.

477 Thermal Conductivity of Oxide Ceramics

Proc. 25th Automotive Technology Development Contractors' Coordination Meeting, pp. 233-38 (Warrendale, Pa.: Society of Automotive Engineers, April 1988)

R. K. Williams, R. S. Graves, D. W. Yarbrough. Oak Ridge National Laboratory, Oak Ridge, Tenn.

478 Ultrasonic Development for Advanced Structural Ceramics

Proc. 25th Automotive Technology Development Contractors' Coordination Meeting, pp. 207-15 (Warrendale, Pa.: Society of Automotive Engineers, April 1988)

W. A. Simpson, R. W. McClung. Oak Ridge National Laboratory, Oak Ridge, Tenn.

479 Ceramic Coatings to Reduce Contact Stress Damage of Ceramics Thermodynamic Modellng

Proc. 25th Automotive Technology Development Contractors' Coordination Meeting, pp. 199-206 (Warrendale, Pa.: Society of Automotive Engineers, April 1988)

H. E. Rebenne, V. K. Sarin. GTE Laboratories, Inc., Wattham, Mass. 
480 Dynamic Tenslie Cycllc Fatigue of $\mathrm{Sl}_{3} \mathrm{~N}_{4}$

Proc. 25th Automotive Technology Development Contractors' Coordination Meeting, pp. 189-97 (Warrendale, Pa.: Society of Automotive Engineers, April 1988)

K. C. Liu, C. R. Brinkman. Oak Ridge National Laboratory, Oak Ridge, Tenn.

481 Testing and Evaluation of $\mathrm{SI}_{3} \mathrm{~N}_{4}$ in Unlaxial Tension at Room Temperature

Proc. 25th Automotive Technology Development Contractors' Coordination Meeting, pp. 175-86 (Warrendale, Pa.: Society of Automotive Engineers, April 1988)

R. Vaidyanathan, J. Sankar, V.S. Awa. North Carolina A\&T State University, Greensboro, N.C.

482 Monollthic $\mathrm{SI}_{3} \mathrm{~N}_{4}$ and SIC Whisker/S/3 $\mathrm{N}_{4}$ Matrix Composite Proc. 25th Automotive Technology Development Contractors' Coordination Meeting, pp. 153-60 (Warrendale, Pa.: Society of Automotive Engineers, April 1988)

K. Teng, H. Yeh. Garrett Ceramic Components Division, Allied-Signal Aerospace Co., Torrance, Calit.

H. Fang, J. Schienle. Garrett Auxiliary Power Division, Allied-Signal Aerospace Co., Phoenix, Ariz.

S. Bradley, K. Karasek. Allied-Signal Engineered Materials Research Center, Des Plaines, III.

483 Development of Toughened $\mathrm{Si}_{3} \mathrm{~N}_{4}$ Composites by Glass Encapsulated Hot Isostatic Pressure

Proc. 25th Automotive Tochnology Development Contractors' Coordination Meeting, pp. 145-51 (Warrendale, Pa.: Society of Automotive Engineers, April 1988)

C. A. Willkens, N. D. Corbin. Norton Co., Northboro, Mass.

484 SIC Whisker-Relnforced $\mathrm{Si}_{3} \mathrm{~N}_{4}$

Proc. 25th Automotive Technology Development Contractors' Coordination Meeting, pp. 137-44 (Wartendale, Pa.: Society of Automotive Engineers, April 1988)

S.-T. Buljan, J. G. Baldoni, M. L. Huckabee, J. T. Neil, G. Zilberstein. GTE Laboratories, Inc., Waltham, Mass.

485 An Assessment of the State of the Art In Predicting the Fallure of Ceramics

ORNL/Sub/86-57598/1 (March 1988)

J. A. M. Boulet. University of Tennessee, Knoxville, Tenn.

486 Ceramic Technology for Advanced Heat Engines Program Data Base: A Summary Report

ORNLM-462 (March 1988)

M. K. Booker. Oak Ridge National Laboratory, Oak Ridge, Tenn.

487 Ceramic Technology for Advanced Heat Englnes Project Semlannual Progress Report for Aprll 1987 Through September 1987 ORNL/TM-10705 (March 1988)

D. R. Johnson. Oak Ridge National Laboratory, Oak Ridge, Tenn.

488 Studles of Dynamic Contact of Ceramics and Alloys for Advanced Heat Englnes

ORNL/Sub/84-00216/1 (March 1988)

K. F. Dufrane, W. A. Glaeser, A. R. Rosenfield. Battelle Columbus Laboratory, Columbus, Ohio 
489 Toughening Behavior in Whisker-Reinforced Ceramic Matrix Composites J. Am. Ceram. Soc. 71, pp. 1050-61 (1988)

P. F. Becher, C. H. Hsueh, P. Angelini, T. N. Tiegs. Oak Ridge National Laboratory, Oak Ridge, Tenn.

490 Brazing of Titanium-Vapor-Coated Sillicon Nitride

Adv. Ceram. Mater. 3, pp. 457-62 (1988)

M. L. Santella. Oak Ridge National Laboratory, Oak Ridge, Tenn.

491 Comparison of Thermal Conductlvity Data for Partlally Stabllized Zirconia With Values Derived From Thermal Diffusivity Results Int. J. Thermophys. 9, pp. 587-98 (1988)

R. K. Williams, J. B. Bates, R. S. Graves, D. L. McElroy, F. J. Weaver. Oak Ridge National Laboratory, Oak Ridge, Tenn.

492 On-Line NDE for Control and Modellng of Ceramic Processing MRS Bull. 13, pp. 34-39 (1988)

R. W. McClung, D. R. Johnson. Oak Ridge National Laboratory, Oak Ridge, Tenn.

493 Temperature Dependence of Strengthening by Whisker Reinforcement: SIC Whisker Reinforced Alumina in Air

Adv. Ceram. Mater. 3, pp. 148-53 (1988)

P. F. Becher, T. N. Tiegs. Oak Ridge National Laboratory, Oak Ridge, Tenn.

494 Use of the Scratch Test to Measure Changes in Adhesion of $\mathrm{Cr} / \mathrm{A}_{2} \mathrm{O}_{3}$ Due to Ion Beam Mixing

J. Adhesion Sci. Technol. 2, pp. 385-93 (1988)

J. E. Pawel. Vanderbitt University, Nashville, Tenn.

C. J. McHargue. Oak Ridge National Laboratory, Oak Ridge, Tenn.

495 Testing of Adhesion of Thin Films to Substrates

J. Adhesion Sci. Technol. 2, pp. 369-83 (1988)

J. E. Pawel. Vanderbilt University, Nashville, Tenn.

C. J. McHargue. Oak Ridge National Laboratory, Oak Ridge, Tenn.

496 Effect of Translucence of Engineering Ceramics on Heat Transfer in Dlesel Englnes

ORNL/Sub/86-22042/1 (October 1987)

S. Wahiduzzaman, T. Morel. Integral Technologies, Inc., Westmont, III.

497 Computer Interfacing of a Raman Spectroscopy Facillty for Application to Quantitative Analyses of Crystalline Phases in TransformationToughened Ceramics

M.S. Thesis, Graduate Engineering and Research School of Engineering, University of Dayton, August 1987

S. J. Pruchnic, Jr. University of Dayton, Dayton, Ohio

498 Needs Assessment for Nondestructive Testing and Materials Characterization for Improved Rellability In structural Ceramics for Heat Englnes

ORNL/TM-10354 (August 1987)

D. R. Johnson, R. W. McClung, M. A. Janney. Oak Ridge National Laboratory, Oak Ridge, Tenn.

W. M. Hanusiak. Consultant to Oak Ridge National Laboratory, Oak Ridge, Tenn. 
499 Ceramic Technology for Advanced Heat Englnes Project Semlannual Progress Report for October 1986 through March 1987 ORNL/TM-10469 (August 1987)

D. R. Johnson. Oak Ridge National Laboratory, Oak Ridge, Tenn.

500 Status of Experimental Studies on the Sol-Gel Synthes/s of Ceramic Powders for High-Strength Ceramic Materials Applications ORNL/TM-9835 (May 1987)

W. D. Bond, G. D. Davis, P. Angelini, P. F. Becher, T. N. Tiegs. Oak Ridge National Laboratory, Oak Ridge, Tenn.

501 Appllcatlon of Laser Raman Macro- and Microprobes Using Cyllndrical Optics to the Study of Zirconla Ceramic Materials

M.S. Thesis, Graduate Engineering and Research School of Engineering, University of Dayton, April 1987

M. L. Lander. University of Dayton, Dayton, Ohio

502 High Temperature Coating Study to Reduce Contact Stress Damage of Ceramics. Final Report

ORNL/Sub/84-47992/1 (March 1987)

J. Schienle, J. Smyth. Garrett Turbine Engine Co., Phoenix, Ariz.

503 Coramic Technology for Advanced Heat Engines Prolect Semlannual Progress Report for Aprll through September 1986 ORNL/TM-10308 (March 1987)

D. R. Johnson. Oak Ridge National Laboratory, Oak Ridge, Tenn.

504 Thermal Shock Behavlor of an Alumina-SiC Whisker Composite J. Am. Ceram. Soc. 70, pp. C109-111 (1987)

T. N. Tiegs, P. F. Becher. Oak Ridge National Laboratory, Oak Ridge, Tenn.

505 The Effects of $\mathrm{Cr}_{2} \mathrm{O}_{3}$ and $\mathrm{Fe}_{2} \mathrm{O}_{3}$ Additions on the Thermal Conductivity of $\mathrm{Al}_{2} \mathrm{O}_{3}$

J. Appl. Physics 61(10), pp. 4894-4901 (1987)

R. K. Williams, R. S. Graves, M. A. Janney, T. N. Tiegs, D. W. Yarbrough. Oak Ridge

National Laboratory, Oak Ridge, Tenn.

506 Deformation Behavior of SIC $\mathrm{V}^{3}$ Isker-Peinforced Sis $\mathrm{N}_{4}$

Advanced Structural Ceramics. Materials, ? tesearch Society Symposia Proceedings 78, өd. P. F. Becher, M. V. Swain and S. Somiya, pp. 295-301 (Pittsburgh, Pa.: Materials Research Society, 1987)

R. Nixon, S. Chevacharoenkul, R. F. Davis. North Carolina State University, Raleigh, N.C.

M. L. Huckabee, S.-T. Buljan. GTE Laboratories, Inc., Waltham, Mass.

507 Evaluation of Commerclally Avallable Transformatlon Toughened Zirconias

Advanced Structural Ceramics. Materials Research Society Symposia Proceedings 78, ed. P. F. Becher, M. V. Swain and S. Somiya, pp. 137-46 (Pittsburgh, Pa.: Materials Research Society, 1987)

J. J. Swab. U.S. Army Materials Technology Laboratory, Watertown, Mass.

508 Microstructure Development In S/3N4-Based Composites

Advanced Structural Ceramics. Materials Research Society Symposia Proceedings 78, ed. P. F. Becher, M. V. Swain and S. Somiya, pp. 273-81 (Pittsburgh, Pa.: Materials

Research Society, 1987)

S.-T. Buljan, G. Zilberstein. GTE Laboratories, Inc., Waltham, Mass. 
$509 \mathrm{SI}_{3} \mathrm{~N}_{4}-\mathrm{SIC}$ Composites

Bull. Am. Coram. Soc. 66(2), pp. 347-52 (1987)

S.-T. Buljan, J. G. Babdoni, M. L. Huckabee. GTE Laboratories, Irc., Waltham, Mass.

510 Relation of Transformation Temperature to the Fracture Toughness of Transformation-Toughened Ceramics

J. Mater. Sci. 22, pp. 76-84 (1987)

P. F. Becher, M. K. Ferber. Oak Ridge National Laboratory, Oak Ridge, Tenn.

M. V. Swain. Advanced Materials Laboratory, CSIRO, Melbourne, Victoria, Australia

511 Mechanlcal Behavior of MgO-Partlally Stabllized $\mathrm{ZrO}_{2}$ Ceramics at Elevated Temperatures

J. Mater. Sci. 22, pp. 973-80 (1987)

P. F. Becher, M. K. Ferber. Oak Ridge National Laboratory, Oak Ridge, Tenn.

512 Sintered $\mathrm{Al}_{2} \mathrm{O}_{3}$-SIC.Whisker Composites

Am. Ceram. Soc. Bull. 66(2), pp. 339-42 (1987)

T. N. Tiegs, P. F. Becher. Oak Ridge National Laboratory, Oak Ridge, Tenn.

513 Wear Mechanisms of Monollthic Ceramics Under Diesel Combustion Chamber

Proceedings of the Third Berkeley Conference on Elevated Temperature Corrosion-

Erosion-Wear of Materials, ed. A. V. Levy, pp. 333-51 (Houston, Texas: National Association of Corrosion Engineers, 1987)

W. A. Glaeser, K. F. Dufrane, A. R. Rosenfield. Battelle Columbus Laboratory, Columbus, Ohio

514 Fracture Toughness Testing of Ceramics Using a Laser Interferometric Straln Gage

Am. Ceram. Soc. Bull. 66(12), pp. 1734-38 (1987)

M. G. Jenkins, A. S. Kobayashi, M. Sakai, K. W. White, R. C. Bract. University of Washington, Seattle, Wash.

515 Crack Initlation and Arrest in an SIC Whisker/A/2O $\mathrm{O}_{3}$ Matrlx Composite J. Am. Ceram. Soc. 70(6), pp. 393-95 (1987)

M. G. Jenkins, A. S. Kobayashi, K. W. White, R. C. Bradt. University of Washington, Seattle, Wash.

516 Disperslon-Toughened $\mathrm{SI}_{3} \mathrm{~N}_{4}$

Proc. 24th Automotive Technology Development Contractors' Coordination Meeting, Dearborn, Michigan, October 27-30, 1986, pp. 319-25 (Warrendale, $\mathrm{Pa}$.: Society of Automotive Engineers, 1987)

M. Martin, H. Yeh. AiResearch Casting Co., Torrance, Calif.

J. Schienle. Garrett Turbine Engine Co., Phoenix, Ariz.

\section{Sintering of Sillcon Nitride}

Proc. 24th Automotive Technology Development Contractors' Coordination Meeting, Dearborn, Michigan, October 27-30, 1986, pp. 295-98 (Warrendale, Pa.: Society of Automotive Engineers, 1987)

G. E. Gazza. U.S. Army Materials Technology Laboratory, Watertown, Mass.

D. W. Heichel. Geo-Centers, Inc., Newton Upper Falls, Mass. 
518 Transformation Toughened Alumina with Improved Strength at Elevated Tomperatures

Proc. 24th Automotive Technology Development Contractors' Coordination Meeting, Dearbom, Michigan, October 27-30, 1986, pp. 285-93 (Warrendale, Pa.: Society of Automotive Engineers, 1987)

R. A. Cutter, J. D. Bright. Ceramatec, Inc., Salt Lake City, Utah

A. V. Virkar, D. K. Shetty. University of Utah, Salt Lake City, Utah

519 Modificatlons in Strength Distrlbutions Due to Slow Crack Growth Proc. 24th Automotive Technology Development Contractors' Coordination Meoting, Deartom, Michigan, October 27-30, 1986, pp. 233-39 (Warrendale, Pa.: Society of Autornotive Engineers, 1987)

C. A. Johnson, W. T. Tucker. General Electric Corporate Research and Development, Schenuctady, N.Y.

520 Environmental Effects on Transformation Toughened Ceramics

Proc. 24th Automotive Technology Development Contractors' Coordination Meeting, Deartom, Michigan, October 27-30, 1986, pp. 209-20 (Warrendale, Pa.: Society of Automotive Engineers, 1987)

N. L. Hecht, S. D. Jang, D. E. McCullum. University of Dayton Research Institute, Dayton, Ohio

521 Fatigue Behavior of Partlally Stabllized Zirconla Ceramics

Proc. 24th Automotive Technology Development Contractors' Coordination Meeting, Deartom, Michigan, October 27-30, 1986, pp. 201-208 (Warrendale, Pa.: Society of Automotive Engineers, 1987)

M. K. Ferber. Oak Ridge National Laboratory, Oak Ridge, Tenn.

T. Hine. University of Illinois Urbana-Champaign, Urbana, III.

522 Tenslle Cyclic Fatigue of Alumina at Room and Elevated Temperatures Proc. 24th Automotive Technology Development Contractors' Coordination Meeting, Deartorn, Michigan, October 27-30, 1986, pp. 191-200 (Warrendale, Pa.: Society of Automotive Engineers, 1987)

K. C. Liu, C. R. Brinkman. Oak Ridge National Laboratory, Oak Ridge, Tenn.

523 Development of Alumina- and Mullite-SIC Whlsker Composites: High Temperature Properties

Proc. 24th Automotive Technology Development Contractors' Coordination Meeting, Dearbom, Michigan, October 27-30, 1986, pp. 279-83 (Warrendale, Pa.: Society of Automotive Engineers, 1987)

T. N. Tiegs, P. F. Becher. Oak Ridge National Laboratory, Oak Ridge, Tenn.

524. Wear of Ceramics in Advanced Heat Englne Applications

1987 Wear of Materials Conference, p. 285 (New York: American Society of Mechanical Engineers, 1987)

K. F. Dutrane, W. A. Glaeser. Battelle Columbus Laboratory, Columbus, Ohio

525 Determination of Phase Composition of Sillicon Nitride Powders by Silicon-29 Magic Angle Spinning Nuclear Magnetic Resonance Spectroscopy

Anal. Chem. 59(23), pp. 2794-97 (1987)

K. R. Carduner, R. O. Carter III, M. E. Milberg, G. M. Crosbie. Ford Motor Co., Dearborn, Mich. 
526 Transient Behavior of Structural Ceramics under Flexural Creep

Proc. Third Intemational Conference on Creep and Fracture of Engineering Materials and Structures, ed. B. Wiltshire and R. W. Evans (London: The Institute of Metals, 1987)

T. J. Chuang, S. M. Wiedertorn, C. F. Chen. National Bureau of Standards, Gaithersburg, Md. 


\section{ALternative FUELS AND PROPULSION TECHNOLOGY}

527 Federal Methanol Fleet Project. Final Report ORNLTM-12278 (March 1993)

B. H. West, R. N. MoGill, S. L. Hillis. Oak Ridge National Laboratory, Oak Ridge, Tenn.

J. W. Hodgson. University of Tennessee, Knoxville, Tenn.

528 Heat Transfer Effectlveness of a Thermal Barrier Coating with Different Fuel Compositions

ORNLTM-11816 (June 1991)

N. Domingo. Oak Ridge National Laboratory, Oak Ridge, Tenn.

529 Results from the Third Year of Operation of the Federal Methanol Fleet at Argonne National Laboratory

ORNLTM-11736 (January 1991)

B. H. West, R. N. McGill. Oak Ridge National Laboratory, Oak Ridge, Tenn.

S. L. Hillis, J. W. Hodgson. University of Tennessee, Knoxville, Tenn.

530 Neat Methanol Combustion in a DI Diesel Engine Using Catalytically Coated Glow Plugs

Altemative Liquid Fuels in Transportation, pp. 97-105, proceedings of the Intemational Fuels and Lubricants Meeting and Exposition, Toronto, Ontario, Canada, October 7-10, 1991, SAE Special Publication 889 (Warrendale, Pa.: Society of Automotive Engineers, 1991)

W. Mitchell, T. A. Litzinger, D. A. Santavioca. The Pennsylvania State University, University Park, Pa.

531 High-Alcohol Microemulsion Fuel Performance In a Diesel Engine SAE* Paper 902101, presented at the 1990 SAE International Fuels and Lubricants Meeting and Exposition, October 22-25, 1990, Tulsa, Oklahoma

B. H. West, A. L. Compere, W. L Griffith. Oak Ridge National Laboratory, Oak Ridge, Tenn.

532 Interpretation of Engine Cycle-to-Cycle Variation by Chaotic Time Series Analysis

SAE Paper 902103, presented at the 1990 SAE International Fuels and Lubricants Meeting and Exposition, October 22-25, 1990, Tulsa, Oklahoma

C. S. Daw, W. K. Kahl. Oak Ridge National Laboratory, Oak Ridge, Tern.

533 Results from the Second Year of Operation of the Federal Methanol Fleet at Oak Ridge National Laboratory ORNLTM-11622 (September 1990)

B. H. West, R. N. McGill. Oak Ridge National Laboratory, Oak Ridge, Tenn.

S. L. Hillis. University of Tennessee, Knoxville, Tenn.

534 Results from the Fourth Year of Operation of the Federal Methanol Fleet at Lawrence Berkeley Laboratory

ORNLTM-11590 (August 1990)

B. H. West, R. N. MoGill. Oak Ridge National Laboratory, Oak Ridge, Tenn.

S. L. Hillis. University of Tennessee, Knoxville, Tenn.

"SAE papers are available from the Society of Automotive Engineers International, 400 Commonwealth Drive, Warrendale PA 15096-0001. 
535 Heavy Duty Llquild and Gaseous Fuel EmIsslons Database Test Results from Four Alternative Fuel Conflgurations of the Caterpillar 3406 Englne ORNL/Sub/86-SB195/1 (June 1990)

D. J. Waldman. Caterpillar, Inc., Technical Center, Peoria, III.

536 Federal Methanol Fleet Update

Proceedings Twenty-Seventh Automotive Technology Development Contractors'

Coordination Meeting, Dearbom, Mich., October 23-26, 1989 P-230, pp. 11-15

(Warrendale, Pa.: Society of Automotive Engineers, April 1990)

R. N. McGill. Oak Ridge National Laboratory, Oak Ridge, Tenn.

\section{Alternative Fuels R\&D Needs Program Directlons}

Proceedings Twenty-Seventh Automotive Technology Development Contractors'

Coordination Meeting, Dearbom, Mich., October 23-26, 1989 P-230, pp. 7-9

(Warrendale, Pa.: Society of Automotive Engineers, April 1990)

R. L. Graves. Oak Ridge National Laboratony, Oak Ridge, Tenn.

\section{Ignition Enhancement of the DDC Methanol Engine}

Proceedings of the Twenty-Seventh Automotive Technology Development Contractors' Coordination Meeting P-230, pp. 23-28 (Warrendale, Pa.: Society of Automotive Engineers, Inc., April 1990)

P. M. Laing, R. E. Winsor. Detroit Diesel Corp., Detroit, Mich.

539 Heavy Duty Llquid and Gaseous Fuel Database Test Results from Four Alternative Conflgurations of the Caterplllar 3406 Englne

Proceedings of the Twenty-Seventh Automotive Technology Development Contractors' Coordination Meeting P-230, pp. 29-41 (Warrendale, Pa.: Society of Automotive Engineers, Inc., April 1990)

D. J. Waldman. Caterpillar, Inc., Peoria, III.

540 Photographic Visualization of the Ignition of Methanol in a Compression Ignitlon Englne

Proceedings of the Twenty-Seventh Automotive Technology Development Contractors'

Coordination Meeting P-230, pp. 17-22 (Warrendale, Pa.: Society of Automotive

Engineers, Inc., April 1990)

D. L. Abata. Michigan Technological University, Houghton, Mich.

541 Performance Comparlsons of Insulated and Non-Insulated Dlesel Engines Proceedings of the Twenty-Seventh Automotive Technology Development Contractors' Coordination Meeting P-230, pp. 75-80 (Warrendale, Pa.: Society of Automotive Engineers, Inc., April 1990)

W. K. Cheng, V. W. Wong, F. Gao. Massachusetts Institute of Technology, Cambridge, Mass.

542 Experimental Heat Transfer Efforts with Thermal Barrler Materlals at ORNL Proc. Workshop on Coatings for Advanced Heat Engines, Castine, Maine, August 59, 1990, pp. IV-53-IV-60 (Washington, D.C.: Department of Energy, 1990)

N. Domingo, M. R. Cates. Oak Ridge National Laboratory, Oak Ridge, Tenn.

\section{Low-Heat-Rejection Engine Research Status: Where Do We Go From} Here?

SAE Paper 900621, presented at the 1990 SAE International Congress and Exposition, February 26-March 2, 1990, Detroit, Michigan

C. S. Reddy. Union College, Schenectady, N.Y.

N. Domingo, R. L. Graves. Oak Ridge National Laboratory, Oak Ridge, Tenn. 
544 Chemical Effect of Fuel Composition Changes on Emissions from a DI Dlesel Englne. Final Report

ORNL/Sub/86-SB020/1 (December 1989)

T. A. Litzinger. The Pennsylvania State University, University Park, Pa.

545 Abnormal Combustion In a Methanol Fueled Engine

SAE paper no. 892162, presented at the 1989 SAE International Fuels and Lubricants Meeting and Exposition, September 1989, Baltimore, Md.

M. R. Swain, J. A. Blanco, M. N. Swain. University of Miami, Coral Gables, Fla.

546 Effects of Fuel/Air Mixture Preparation on Fuel Nitrogen Conversion In a Spark Ignition Engine

SAE paper no. 892161, presented at the 1989 SAE International Fuels and Lubricants Meeting and Exposition, September 1989, Baltimore, Md.

J. W. Hodgson. University of Tennessee, Knoxville, Tenn.

R. N. McGill. Oak Ridge National Laboratory, Oak Ridge, Tenn.

547 The Effect of Hydro Treatment of Coal-Derlved Synthetlc Fuels on DI Dlesel Emissions and Performance

SAE paper no. 892132, presented at the 1989 SAE International Fuels and Lubricants Meeting and Exposition, September 1989, Baltimore, Md.

J. H. Palumbo, T. A. Litzinger. Pennsylvania Stace University, University Park, Pa.

548 Hydroprocessing of Direct Coal Liquefaction Product for Diesel Engine

\section{Fuel}

SAE paper no. 892131, presented at the 1989 SAE International Fuels and Lubricants

Meeting and Exposition, September 1989, Baltimore, Md.

N. R. Sefer, J. Erwin. Southwest Research Institute, San Antonio, Texas

549 The Effect of Aromatics and Cycloparaffins on DI Diesel Emissions

SAE paper no. 892130, presented at the 1989 SAE International Fuels and Lubricants Meeting and Exposition, September 1989, Baltimore, Md.

C. T. Flanigan, T. A. Litzinger. Pennsylvania State University, University Park, Pa.

R. L. Graves. Oak Ridge National Laboratory, Oak Ridge, Tenn.

550 Thermal Barrler Effects on Performance and EmIssions of a Methanol Fueled DI Engine

SAE paper no. 892163, presented at the 1989 SAE International Fuels and Lubricants Meeting and Exposition, September 1989, Baltimore, Md.

W. K. Kahl. Oak Ridge National Laboratory, Oak Ridge, Tenn.

551 Results from the Second Year of Operation of the Federal Methanol Fleet at Argonne Natlonal Laboratory

ORNLTM-11230 (August 1989)

R. N. McGill, B. H. West. Oak Ridge National Laboratory, Oak Ridge, Tenn.

S. L. Hillis, J. W. Hodgson. University of Tennessee, Knoxville, Tenn.

552 Results from the First Year of Operation of the Federal Methanol Fleet at Oak Ridge National Laboratory

ORNLTM-11229 (July 1989)

R. N. McGill, B. H. West. Oak Ridge National Laboratory, Oak Ridge, Tenn.

S. L. Hillis, J. W. Hodgson. University of Tennessee, Knoxville, Tenn.

553 Fuel Nitrogen Conversion in a Spark Ignition Engine Part II: Effects of Fuel/AIr Mixture Preparation

ORNL/Sub/87-07685/1 (February 1989)

J. W. Hodgson. University of Tennessee, Knoxville, Tenn. 
554 Analysls of the Combustion of Four Alternate Fuels in a Dlesel Engine Using Hilgh Speed Photography. Final Report

ORNL/Sub/87-91333/1 (February 1989)

D. L. Abatר, D. Masterson. Michigan Technological University, Houghton, Mich.

555 Evaluation of the Fffects of Natural Gas Contaminants on Corrosion in Compressed Natural Gas Storage Systems-Phase II

ORNL/Sub/85-22025/1 (January 1989)

F. F. Lyle, Jr. Southwest Research Institute, San Antonio, Texas

556 Th, Department of Energy's Federal Methanol Fleot-A Progress Report SAE paper no. 881629, presented at the 1988 SAE Fuels and Lubricants Meeting and Exposition, October $19 \div 8$, Portland, Ore.

R. ':. McGill. Oak Ridge National Laboratory, Oak Ridge, Tenn.

S. L. Hillis. University of Tennessee, Knoxville, Tenn.

557 Effect of Reduced Combustion Chamber Heat Loss on Alternatlve Fuels Combustion

SAE paper no. 881628, presented at the 1988 SAE Fuels and Lubricants Meeting and Exposition, October 1988, Portland, Ore.

C. E. Huntei, E. E. Daby, I. J. Ganwin, P. H. Havstad. Ford Motor Co., Dearbom, Mich.

558 Shale-Derlved Dlesel Test Fuels for UtIlization Studles

SAE paper no. 381627, presented at the 1988 SAE Fuels and Lubricants Meeting and

Exposition, Uctober 1988, Portland, Ore.

J. Enwin, N. R. Sefer. Southwest Research Institute, San Antonio, Texas

559 Englne and Constant Volume Bomb Studies of Dlesel Ignition and Combustion

SAE paper no. 881626, presented at the 1988 SAE Fuels and Lubricants Meeting and Expositicn, October 1988, Portland, Ore.

T. W. F.; an III, T. J. Callahan. Southwest Research Institute, San Antonio, Texas

560 Results from the First Year of Operation of the Federal Methanol Fleet at Argonne Natlonal Laboratory

ORNL/TM-10816 (October 1988)

R. N. McGill. Oak Ridge National Laboratory, Oak Ridge, Tenn.

S. L. Hillis. University of Tennessee, Knoxville, Tenn.

R. P. Larsen. Argonne National Laboratory, Argonne, III.

561 Research Program on RG.'uced Combustion Chamber Heat Loss Effects on Alternative Fuel Combustion

ORNL/Sub/87-95918/1 (October 1988)

C. E. Hunter, P. H. Havstad, I. J. Garwin, E. E. Daby. Ford Motor Co., Dearbom, Mich.

562 Fuel Alcohol Formations

DOE/CE/50181-H1* (Washington, D.C.: Department of Energy, September 1988)

Swedish Motor Fuel Technology Co., Stockholm, Sweden

"Ávailabie irom the Naationái Technical information Service, U.S. Department of Energy, 5285 Pont

Royal Road, Springfield VA 22161. 
563 Results from the Second Year of Operation of the Federal Methanol Fleet at Lawrence Berkeley Laboratory

ORNL/TM-10815 (August 1988)

R. N. MoGill. Oak Ridge National Laboratory, Oak Ridge, Tenn.

S. L. Hillis. University of Tennessee, Knoxville, Tenn.

564 Technical Highllghts of the Alternative Fuels Utllization Program

Proc. 25th Automotive Technology Developmen, Lontractors' Coordination Meeting, pp.

77-82 (Warrendale, Pa.: Society of Automotive Engineers, April 1988)

R. L. Graves. Oak Ridge National Laboratory, Oak Ridge, Tenn.

565 An Investigation of High Pressure/Late Cycle Injection of CNG as a Fuel for Rall Applications

ORNL/Sub/85-22032/1 (April 1988)

J. F. Wakeriell, G. G. O'Neal, Q. A. Baker, C. M. Uiban. Southwest Research Institute, San Antonio, Texas

566 Status of Alcohol Fuels Utilization Technology for Highway Transportation: A 1986 Perspective

ORNL/Sub/85-22007/4 (February 1988)

R. L. Bechtold. Mueller Associates, Inc., Baltimore, Md.

567 A Gulde to the Planning and Management of Vehicle Fleet Tests to Obtain Significant Results

ORNL/Sub/85-22007/2 (February 1988)

R. L. Bechtold. Mueller Associates, Inc., Baltimore, Md.

568 Status of Alcohol Fuels UtIlization Technology for Highway

Transportation: A 1986 Perspective. Volume || Compression Ignition Systems

ORNL/SUb/85-22007/3 (January 1988)

R. L. Bechtold. Mueller Associates, Inc., Baltimore, Md.

569 Engine Testing for Synfuel Operation

ORNLSSub/85-28609/1 (January 1988)

D. W. Dickey, S. Vinyard, T. J. Callahan, T. W. Ryan III, M. A. Wamer.Selph, N. R. Sefer.

Southwest Research Institute, San Antonio, Texas

570 First Year Results from the Federal Methanol Fleet at the Lawrence Berkeley Laboratory

SAE paper no. 872042, presented at the 1987 SAE International Fuels and Lubricants Meeting and Exposition, November 1987, Toronto, Ontario, Canada

R. N. McGill, J. L. Wantland. Oak Ridge Natioral Laboratory, Cak Ridge, Tenn.

S. L. Hillis. University of Tennessee, Knoxville, Tenn.

571 High-Pressure Late Cycle Direct Injection of Natural Gas In a Rall Medium Speed Dlesel Englne

SAE paper no. 872041, presented at the 1987 SAE International Fuels and Lubricants Meeting and Exposition, November 1987, Toronto, Ontario, Canada

J. F. Wakenell, G. G. O'Neal. Southwest Research Institute, San Antonio, Texas

Q. A. Baker. Wilfred Baker Engineering, San Antonio, Texas

572 The Effect of Alternatlve Gasollnes on Knock and Intake Valve Sticking SAE paper no. 872040, presented at the 1987 SAE International Fuels and Lubricants Meeting and Exposition, November 1987, Toronto, Ontario, Canada

M. R. Swain, M. N. Swain, J. A. Blanco, R. R. Adt. University of Miami, Coral Gables, Fla. 
573 Fuel Nitrogen Conversion In a Spark Ignition Englne

SAE paper no. 872039, presented at the 1987 SAE International Fuels and Lubricants Meeting and Exposition, November 1987, Toronto, Ontario, Canada J. W. Hodgson, J. C. Denny. University of Tennessee, Knoxville, Tenn.

R. N. McGill. Oak Ridge National Laboratory, Oak Ridge, Tenn.

574 Production and Analysls of EDS Coal-Derived Middle DIstillate Test Fuels from Hydrogenation at Threo Levels of Severity

SAE paper no. 872038, presented at the 1987 SAE International Fuels and Lubricants Meeting and Exposition, November 1987, Toronto, Ontario, Canada

J. Enwin, N. R. Sefer. Southwest Research Institute, San Antonio, Texas

B. Glavincevski. National Research Council of Canada, Ottawa, Ontario

575 A Comparison of Three Coal-Derlved, Middle Distlliate, Alternative Fuels In a Single-Cylinder DI Dlesel Englne

SAE paper no. 872037, presented at the 1987 SAE International Fuels and Lubricants Meeting and Exposition, November 1987, Toronto, Ontario, Canada

T. G. Buzza, T. A. Litzinger. Pennsylvania State University, University Park, Pa.

576 Ignition Delay as Determined in a Varlable Compression Ratio Direct Injection Dlesel Engine

SAE paper no. 872036, presented at the 1987 SAE Imternational Fuels and Lubricants Meeting and Exposition, November 1987, Toronto, Ontario, Canada

T. W. Ryan III. Southwest Research Institute, San Antonio, Texas

577 The Influence of Fuel Composition and Spray Characterlstics on Soot Formation

SAE paper no. 872035 , presented at the 1987 SAE International Fuels and Lubricants Meeting and Exposition, November 1987, Toronto, Ontario, Canada

K. K. Rink, A. H. Lefebvre. Purdue University, West Lafayette, Ind.

R. L. Graves. Oak Ridge National Laboratory, Oak Ridge, Tenn.

578 The Effects of Fuel Composition on Ignition Delay In Homogeneous Charge and Direct Injection Compression Ignition Engines ORNLSUb/84-89677/1 (November 1987)

D. E. Foster, P. M. Dimpelfeld, D. L. Boggs, R. E. Bair, G. L. Borman. University of Wisconsin, Madison, Wis.

579 Fuel Nitrogen Conversion In a Supercharged Spark Ignition Engine ORNL/Sub/85-97367/1 (October 1987)

J. W. Hodgson, J. C. Denny. University of Tennessee, Knoxville, Tenn.

580 Results from the First Year of Operation of the Federal Methanol Fleet at Lawrence Berkeley Laboratory

ORNLTM-10485 (August 1987)

R. N. McGill, J. L. Wantland. Oak Ridge National Laboratory, Oak Ridge, Tenn.

S. L. Hillis. University of Tennessee, Knoxville, Tenn.

581 Compendium of Significant Events in the Recent Development of Alcohol Fuels in the Unlted States

ORNL/Sub/85-22007/1 (June 1987)

R. L. Bechtold. Mueller Associates, Baltimore, Md.

582 Alternative Fuels Utllization Program Project Office Operating Plan for Fy $1986-87$

ORNLTM-10435 (June 1987)

R. L. Graves, R. N. McGill. Oak Ridge National Laboratory, Oak Ridge, Tenn. 
583 Utillzation of Alternative Fuels in Diesel Englnes

DOE/CE/0212* (Washington, D.C.: Department of Energy, June 1987)

Pennsylvania State University, University Park, Pa.

584 Pollutant Formation in Heterogeneous Mixtures of Fuel Drops in Alr DOE/CE/50052-H1* (Washington, D.C.: Department of Energy, May 1987)

A. H. Lefebvre. Purdue University, West Lafayette, Ind.

585 A Comparlson of Unburned Fuel and Aldehyde EmIssions from a Methanol-Fueled Stratlfied Charge and Homogeneous Charge Englne ORNL/Sub/86-97366/1 (March 1987)

D. E. Foster, C. Kim, N. Scull. University of Wisconsin, Madison, Wis.

586 Alternative Fuel Porformance and EmIsslons Characterlstics DOE/CS/50028-H1* (Washington, D.C.: Department of Energy, January 1987) University of Miami, Coral Gables, Fla.

587 Testing of Developmental Ceramic Materlals in Diesel Englne Combustion Chambers

Proceedings of the American Society of Mechanical Engineers Automotive Engine Technology Symposium, Dallas, Texas, February 16-18, 1987 (New York: ASME, 1987)

R. L. Graves, W. '?. Kahl, E. L. Long, Jr. Oak Ridge National Laboratory, Oak Ridge, Tenn.

- Available from the National Technical Information Service, U.S. Department of Commerce, 5285 Pon Royal Road, Springtield VÁ 22161. 


\section{MICROEMULSION FUELS}

588 Correlating Microemulsion Fuel Composition, Structure, and Combustion Propertles

ORNLTM-11248 (September 1989)

W. L. Gritfith, A. L Compere. Oak Ridge National Laboratory, Oak Ridge, Tenn.

589 Small Angle Scattering From Micelles of Potasslum Salts of 18-Carbon Fatty Acids

Langmuir 5, pp. 1191-95 (1989)

J. S. Johnson, Jr., W. L. Gritfith, A. L. Compere. Oak Ridge National Laboratory, Oak Ridge, Tenn.

590 Effect of Composition on Sizes of W/O Ethanolamine-Olelc Acld Mlcroemulsions by Small-Angle Neutron Scattering

Langmuir 5(2), pp. 357-63 (1989)

E. Caponetti, R. Triolo, A. Lizzio. Istituto Chimica Fisica, University of Palermo, Palermo, Haly

W. L. Griffith, J. S. Johnson, Jr., A. L. Compere. Oak Ridge National Laboratory, Oak Ridge, Tenn.

591 Analysis of Small-Angle Scattering Patterns from Preclpltating Alloys Physical Review B 39(7), pp. 4588-94 (1989)

R. Triolo, E. C. Caponetti. Istituto Chimica Fisica, University of Palermo, Palermo, Italy

S. Spooner. Oak Ridge National Laboratory, Oak Ridge, Tenn.

592 Opportunities for Improved Energy Recovery In Pulp MIIIs

Alternative Energy Sources VIII. Proceedings of the Eighth Miami International Conference, Miami, Fla., December 14-16, 1987, 2, pp. 755-68 (Washington, D.C.: Hemisphere Press, 1989)

A. L. Compere, W. L. Griffith. Oak Ridge National Laboratory, Oak Ridge, Tenn.

T. W. Joyce. North Carolina State University, Raleigh, N.C.

593 Energy Conservation Benefits Incidental to Microemulsion Fuel Use ORNLTM-10882 (July 1988)

A. L. Compere, W. L. Griffith. Oak Ridge National Laboratory, Oak Ridge, Tenn.

594 Effect of Surfactant Neutrallzation of Hexadecane/Water-1Pentanol/Olelc Acid/Ethanolamine Microemulslons A SANS Study Langmuir 4(3), pp. 606-10 (1988)

E. Caponetti, R. Triolo. Istituto Chimica Fisica, University of Palermo, Palermo, Haly W. L. Griffith, J. S. Johnson, Jr., A. L. Compere. Oak Ridge National Laboratory, Oak Ridge, Tenn.

595 Effect of Posslble Interferences on the Extraction of 1-butanol from Aqueous Solution by the Ethyl Esters of Soybean Oll Fatty Aclds Separation Science and Technology 22(2\&3), pp. 373-78 (1987)

W. L. Griffith, A. L. Compere. Oak Ridge National Laboratory, Oak Ridge, Tenn. J. M. Googin. Y-12 Plant, Oak Ridge, Tenn.

596 Small-angle Neutron Scattering from Micelles of Aklylpolyoxyethylene Sulfate: Effect of Chain Length

J. Solut. Chem. 16(4), pp. 295-306 (1987)

E. Caponetti, R. Triolo. Istituto Chimica Fisica, University of Palermo, Palermo, Haly

J. S. Johnson, Jr. Oak Ridge National Laboratory, Oak Ridge, Tenn. 
597 Analytical Scattering Functlon of a Polydisperse Percus-Yevick Fluld with Schulz- (gamma-) Distrlbuted Diameters

Physical Review A 35(5), pp. 2200-06 (1987)

W. L. Gritfith, A. L. Compere. Oak Ridge National Laboratory, Oak Ridge, Tenn.

R. Triolo. Istituto Chimica Fisica, University of Palermo, Palermo, Haly 


\section{INDUSTRIAL CHEMICAL HEAT PUMPS}

598 Materlals Corrosion in Ammonla/Solld Heat Pump in Working Media ORNL/TM-12004 (January 1992)

D F. Wilson, M. Howell, J. H. DeVan. Oak Ridge National Laboratory, Oak Ridge, Tenn.

599 Methods for Predicting Propertles and Talloring Salt Solutions for Industrial Processes

Technology 2002: Conference Proceedings, The Third National Technology Transfer Conference and Exposition, December 1-3, 1992, NASA-CP-3189 (Washington, D.C.: National Aeronautics and Space Administration, 1992)

M. R. Aly. Oak Ridge National Laboratory, Jak Ridge, Tenn.

600 Refractlve Indexes of Aqueous LIBr Solutions

J. Chem. Eng. Data 37, pp. 110-13 (1992)

A. Zaltash, M. R. Ally. Oak Ridge National Laboratory, Oak Ridge, Tenn.

601 Valldation of a PC Based Program for Single Stage Absorption Heat Pump

ORNL/TM-11923 (September 1991)

A Zaltash, M. R. Ally. Oak Ridge National Laboratory, Oak Ridge, Tenn.

602 Effect of Additives on the Film Heat Transfer Coefficlents of $(\mathrm{LI}, \mathrm{K}, \mathrm{Na})_{\mathrm{NO}} \mathrm{O}_{3}$ and $\mathrm{LIBr}$ AqueOus MIxtures

Proceedings of the XVIII International Congress of Refrigeration, Montreal, Quebec, August 10-15, 1991, paper no. 52 (Paris: International Institute of Refrigeration, 1991) A. Zaltash, M. R. Ally, R. L. Linkous, R. H. Reiner. Oak Ridge National Laboratory, Oak Ridge, Tenn.

603 Densitles and Refractive Indexes of Aqueous (LI,K,Na)NO 3 MIxtures J. Chem. Eng. Data 36, pp. 209-13 (1991)

M. R. Ally, L. N. Klatt, A. Zaltash, R. L. Linkous. Oak Ridge National Laboratory, Oak Ridge, Tenn.

604 Measurements of Heat and Mass Transfer Coefficlents During Absorption of Water Vapor by Lithlum Bromide and $(\mathrm{LI}, \mathrm{K}, \mathrm{Na}) \mathrm{NO}_{3}$ Mixtures Heat Pump Design, Analysis, and Application AES 26, pp. 83-90 (New York: American Society of Mechanical Engineers, 1991)

A. Zaltash, M. R. Ally, R. L. Linkous, L. N. Klatt. Oak Ridge National Laboratory, Oak Ridge, Tenn.

605 Corrosion of Materlals in Chemical Heat Pump Working Flulds ORNLTM-10896 (November 1988)

J. H. DeVan, J. S. WoH. Oak Ridge National Laboratory, Oak Ridge, Tenn.

606 Computer SImulation of Absorption Heat Pump Using Aqueous LIthium Bromide and Ternary Nitrate Mixtures

ORNL/TM-10392 (June 1988)

M. R. Ally. Oak Ridge National Laboratory, Oak Ridge, Tenn.

607 Vapoi LIquid Equllibrium (VLE) and Enthalpy-Concentration-Temperature (H-X-T) Correlatlons for Ternary Nitrate Mixtures

ASHRAE Tra.7s 94(2) (Atlanta: American Society of Heating, Refrigerating, and Air Conditioning Engineers, 1988)

M. R. Ally. Oak Ridge National Laboratory, Oak Ridge, Tenn. 
608 Design Conslderatlons for Flxed-Bed Metal Hydrlde Heat Pumps for High Temperature Boosts

ASHRAE Trans 94(1), pp. 267-79 (Atlanta: American Society of Heating, Refrigerating, and Air Conditioning Engineers, 1988)

M. R. Ally. Oak Ridge National Laboratory, Oak Ridge, Tenn.

609 Simulated Performance of Absorption Heat Pumps Using a Mixed Aqueous Nitrate Working Fluid

ASME* paper no. 87-WAAES-2, presented at the ASME Winter Annual Meeting,

Boston, Mass., December 13-18, 1987

M. R. Ally. Oak Ridge National Laboratory, Oak Ridge, Tenn.

610 Ideal Fluid Propertles for Optimizing Absorption Heat Pump Performance ORNLTM-10315 (April 1987)

H. Perez-Blanco, M. R. Patterson, J. Braunstein. Oak Ridge National Laboratory, Oak Ridge, Tenn.

611 Thermodynamic Propertles of Aqueous Ternary Solutlons Relevant to Chemical Heat Pumps. Final Report

ORNLTM-10258 (March 1987)

M. R. Ally. Oak Ridge National Laboratory, Oak Ridge, Tenn.

612 Carnot Thermal Efficlencles of Chemical Heat Pumps Operating Between Four Temperature Levels A Heurlstic Approach

ASHRAE Trans 93(2), pp. 2442-53 (Atlanta: American Society of Heating, Refrigerating, and Air Conditioning Engineers, 1987)

M. R. Ally. Oak Ridge National Laboratory, Oak Ridge, Tenn.

"Available from the Anierican Society of Mechanical Engineers, 345 East 47th Street, New York, N.Y. 10017. 


\section{MATERIALS FOR ADVANCED INDUSTRIAL HEAT EXCHANGERS}

613 High-Temperature Corrosion of Ceramic-Ceramic Composites in a Waste Incinerator Environment ORNLTM-12212 (January 1993)

J. R. Keiser, J. I. Federer, T. J. Henson, D. L. Hindman. Oak Ridge National Laboratory, Oak Ridge, Tenn.

614 Development of a Zirconla-Mullite Based Ceramic for Recuperator Appllcations

ORNL/Sub/86-22044/2 (December 1992)

J. M. Gonalez, GTE Products Corp., Towanda, Pa.

615 Rheology of Zirconla-Alumina Gelcasting Slurries

Proceodings of the Spring Meeting, Materials Research Society, San Francisco, April 27May 1, 1992, 271, pp. 269-75 (Pittsburgh: Materials Research Society, 1992)

A. Bleier, O. O. Omatete, C. G. Westmoreland. Oak Ridge National Laboratory, Oak Ridge, Tenn.

616 Corrosion of SIC and Oxide-Composite Ceramics by a Simulated SteamReformer Atmosphere

ORNL/TM-11828 (September 1991)

J. I. Federer, H. E. Kim, A. J. Moorhead. Oak Ridge National Laboratory, Oak Ridge, Tenn.

617 Corrosion Behavior of Continuous-Filament-Wound Ceramic Composite Tubes

ORNLTM-11691 (May 1991)

J. I. Federer. Oak Ridge National Laboratory, Oak Ridge, Tenn.

618 Gelcast Reaction-Bonded Sillcon Nitride Composites

Ceramic Engineering and Science Proceedings 12, proceedings of the 15th Annual

Conference on Composites and Advanced Ceramic Materials, Cocoa Beach, Fla., January

13-16, 1991 (Westerville, Ohio: American Ceramic Society, 1991)

O. O. Omatete, T. N. Tiegs, A. C. Young. Oak Ridge National Laboratory, Oak Ridge, Tenn.

619 Construction and Testing of a Flue-Gas Corrosion Probe ORNL-6630 (August 1990)

J. I. Federer, J. A. McEvers. Oak Ridge National Laboratory, Oak Ridge, Tenn.

620 Design Methodology Needs for Flber-Relnforced Ceramic Heat Exchangers

ORNLTM-11012 (August 1990)

J. J. Blass, M. B. Ruggles. Oak Ridge National Laboratory, Oak Ridge, Tenn.

621 Alumina-Base Coatings for Protection of SIC Ceramics

$J$ Mater. Eng. 12, pp. 141-49 (1990)

J. I. Federer. Oak Ridge National Laboratory, Oak Ridge, Tenn.

622 Selection of Corrosion Resistant Materials For Use In Molten Nitrate Salts ORNLTM-11162 (October 1989)

P. F. Tortorelli, P. S. Bishop, J. R. DiStefano. Oak Ridge National Laboratory, Oak Ridge, Tenn. 
623 Extrusion of Alumina-Sillcon Carblde Whisker Composites ORNLTM-10373 (October 1989)

M. A. Janney, E. S. Bomar, M. C. Vance. Oak Ridge National Laboratory, Oak Ridge, Tenn.

624 High-Temperature Corrosion of Metallic Alloys in an Oxidizing Atmosphere Contalning $\mathrm{NaCl}$

ORNLTM-11029 (February 1989)

J. I. Federer. Oak Ridge National Laboratory, Oak Ridge, Tenn.

625 Ceramic Heat Exchangers: Cost Estimates Using a Process-Cost

Approach

ORNLTM-10684 (August 1988)

S. Das, T. R. Curlee, R. A. Whitaker. Oak Ridge National Laboratory, Oak Ridge, Tenn.

626 An Investigation of Ceramic Coatings for Protection of SiC from High. Temperature Corrosion

ORNLTM-10606 (February 1988)

J. I. Federer. Oak Ridge National Laboratory, Oak Ridge, Tenn.

627 Stress-Corrosion of SIC in an Oxidizing Atmosphere Containing $\mathrm{NaCl}$ Advanced Ceramic Materials 3, pp. 293-95 (1988)

J. I. Federer. Oak Ridge National Laboratory, Oak Ridge, Tenn.

628 Corrosion of SiC Ceramics by $\mathrm{Na}_{2} \mathrm{SO}_{4}$

Advanced Ceramic Materials 3(1), pp. 56-61 (1988)

J. I. Federer. Oak Ridge National Laboratory, Oak Ridge, Tenn.

629 Degradation of Materials by Industrial Combustion Environments: " Metals

Industrial Heating LIV(7), pp. 32-33 (July 1987)

J. I. Federer. Oak Ridge National Laboratory, Oak Ridge, Tenn.

630 Degradation of Materials by Industrlal Combustion Environments: I Refractorles Industrial Heating LIV(4), pp. 12-15 (April 1987)

J. I. Federer. Oak Ridge National Laboratory, Oak Ridge, Tenn.

631 Bibllography of Ceramic Extrusion and Plasticlty ORNL-6363 (March 1987)

M. A. Janney, M. C. Vance, A. C. Jordan, M. P. Kertesz. Oak Ridge National Laboratory, Oak Ridge, Tenn.

632 Production of Fine, High-Purity, Beta SiC Powder Ceramic Powder Science. Proceedings of the Ceramic Powder Science and Technology: Synthesis, Processing, and Characterization Conference, August 3-6, 1986, Boston, Massachusetts, ed. Gary L. Messing et al., Advances in Ceramics 21, pp. 255-63 (Westerville, Ohio: American Ceramic Society, 1987)

P. T. B. Shaffer, K. A. Blakely. Advanced Refractory Techniques, Inc., Buffalo, N.Y. M. A. Janney. Oak Ridge National Laboratory, Oak Ridge, Tenn. 


\section{ADVANCED INDUSTRIAL MATERIALS}

633 Weld Solldification Cracking In Cast N/3Al Alloys

Scr. Metall. et Mater. 28(11), pp. 1305-10 (June 1, 1993)

M. L. Santella. Oak Ridge National Laboratory, Oak Ridge, Tenn.

634 Microstructural Effects on Surface Mechanical Propertles of Ion Implanted Polymers

J. Mater. Res. 8(4), pp. 927-33 (April 1993)

G. R. Rao. Aubum University, Auburn, Ala.

Z. L. Wang, E. H. Lee. Oak Ridge National Laboratory, Oak Ridge, Tenn.

635 Hardness Measurements of Art-Beam Treated Polyimide by DepthSensing UItra Low Load Indentation

J. Mater. Res. 8(2), pp. $377-87$ (February 1993)

E. H. Lee, W. C. Oliver, L. K. Mansur. Oak Ridge National Laboratory, Oak Ridge, Tenn. Y. Lee. Korea Academy of Industrial Technology, Seoul, Korea

636 Calculation of the Electronic Properties of NI-P Amorphous Alloys Phys. Rev. B 47(1), pp. 107-14 (January 1, 1993-I)

H. Yang, J. C. Swihart. Indiana University, Bloomington, Ind.

D. M. Nicholson. Oak Ridge National Laboratory, Oak Ridge, Tenn.

R. H. Brown. Luther college, Decorah, lowa

\section{Chemical Vapor Infiltration of $\mathrm{TIB}_{2}$ Composites}

ORNLTM-12214 (January 1993)

T. M. Besmann, J. H. Miller, K. C. Cooley, R. A. Lowden, T. L. Starr. Oak Ridge National Laboratory, Oak Ridge, Tenn.

638 Effects of Minor Alloying Elements on the Welding Behavior of FeAl Alloys for Structural and Weld-Overlay Cladding Appllcations Scr. Metall. et Mater. 27(12), pp. 1835-40 (December 15, 1992)

P. J. Maziasz, G. M. Goodwin, C. T. Liu, S. A. David. Oak Ridge National Laboratory, Oak Ridge, Tenn.

639 Chemical Vapor Deposition of Refractory Metals and Ceramics II: Symposium held December 4-6, 1991, Boston, Massachusetts Materials Research Society Symposium Proceedings, 250 (Pittsburgh: Materials Research Society, 1992)

T. M. Besmann, ed. Oak Ridge National Laboratory, Oak Ridge, Tenn.

B. M. Gallois, ed. Stevens Institute of Technology, Hoboken, N.J.

J. W. Warren, ed. Composite Innovation Corp., Woodland Hills, Calif.

\section{Multlkllowatt Varlable Frequency Microwave Furnace}

Proceedings, Spring Meeting, Materials Research Society, San Francisco, April 27-May 1, 1992, 269, pp. 77-81 (Pittsburgh: Materials Research Society, 1992)

D. W. Bible, R. J. Lauf. Oak Ridge National Laboratory, Oak Ridge, Tenn.

C. A. Everleigh. Microwave Laboratories, Inc., Raleigh, N. C.

\section{Rheology of Zirconla-Alumina Gelcasting Slurries}

Proceodings, Spring Meeting, Materials Research Society, San Francisco, April 27-May 1, 1992; 271, pp. $269-75$ (Pittsburgh: Materials Research Society, 1992)

A. Bleier, O. O. Omatete, C. G. Westmoreland. Oak Ridge National Laboratory, Oak Ridge, Tenn. 


\section{Characterization of the Phase Transformations in the Shape Memory} Alloy NI-36 atm \% Al

Proceodings, Fall Moeting, Materials Research Society, Boston, December 2-6, 1992 246, pp. 61-66 (Pittsburgh: Materials Research Society, 1992)

J. A. Horton, E. P. George, C. J. Sparks, O. B. Cavin. Oak Ridge National Laboratory, Oak Ridge, Tenn.

M. Y. Kao, P. Thoma. Johnson Controls, Inc., Milwaukee, Wis.

643 Microwave Processing of Ceramics: Guldelines Used at the Oak Ridge Natlonal Laboratory

Proceedings, Spring Meeting, Materials Research Society, San Francisco, April 27-May 1, 1992, 269, pp. 173-85 (Pittsburgh: Materials Research Society, 1992)

M. A. Janney, H. D. Kimrey, J. O. Kiggans. Oak Ridge National Laboratory, Oak Ridge, Tenn.

644 Microwave Sintering of Multllayer Ceramic Capacitors Proceedings, Spring Meeting, Materials Research Society, San Francisco, April 27-May 1, 1992, 269, pp. 223-29 (Pittsburgh: Materials Research Society, 1992)

R. J. Lauf, C. Hamby. Oak Ridge National Laboratory, Oak Ridge, Tenn.

C. E. Holcombe. Y-12 Plant, Oak Ridge, Tenn.

645 Elevated-Temperature Environmental Embrittlement and Alloy Design of L/2 Ordered Intermetallics

Mater. Sci. Eng. A153, pp. 538-47 (1992)

M. Takeyama. National Research Institute for Metals, Tokyo, Japan

C. T. Liu. Oak Ridge National Laboratory, Oak Ridge, Tenn.

646 First Principles Theory of Alloy Phase Stabllity. Ordering and PreMartensitic Phenomena In Beta-Phase NIAl

Proceedings, NATO Advanced Research Workshop on Ordered Intermetallics-Physical Metallurgy and Mechanical Behaviour, Irsee, Germany, June 23-29, 1991, pp. 15-36

(The Netherlands: Klūwer Publishers, 1992)

G. M. Stocks, W. A. Shelton, D. M. Nicholson. Oak Ridge National Laboratory, Oak Ridge, Tenn.

F. J. Pinski. University of Cincinnati, Cincinnati, Ohio

B. Ginatempo. University of Messina, Messina, thaly

A. Barbieri, B. L. Gyortfy. University of Bristol, Bristol, Great Britain

D. D. Johnson. Sandia National Laboratory, Livermore, Calif.

J. B. Staunton. University of Wanwick, Coventry, Great Britain

P. E. A. Turchi, M. Sluiter. Lawrence Livermore National Laboratory, Livermore, Calif.

647 Cracking Behavior of FeAl (40 at. \% Al) Alloys During Cutting Operations Scr. Metall. 26, pp. 1669-74 (1992)

P. A. Ferguson. North Carolina State University, Raleigh, N.C.

C. T. Liu. Oak Ridge National Laboratory, Oak Ridge, Tenn.

648 The Role of Microscopy in the Alloy Design of NI- and Fe-Based Aluminides

Proceodings of the 50th Annual Meeting of the Electron Microscope Society of America, Boston, August 16-21, 1992, pp. 168-69 (San Francisco Press, 1992)

J. A. Horton. Oak Ridge National Laboratory, Oak Ridge, Tenn. 
649 Multiple-lon Irradlatlons: Facllity Review and Highllghts of Applications to Metals, Ceramics, and Polymers

Proceedings of the 16th International Symposium on Effects of Radiation on Materials, Denver, June 21-22, 1992 (Philadelphia, Pa.: American Society for Testing and Materials, 1992)

L. K. Mansur, E. H. Lee, M. B. Lewis, S. J. Zinkle. Oak Ridge National Laboratory, Oak Ridge, Tenn.

650 Models for Heat Transport Through Assemblles of Unlform-Dlameter Hollow Spheres

ORNLTM-11397 (April 1991)

D. W. Yarbrough, D. L. McElroy, F. J. Weaver. Oak Ridge National Laboratory, Oak Ridge, Tenn.

651 Ground State Propertles and Magnetlsm In Substltutlonally Disordered Fe 1-xCrx Alloys

Proceedings of the Spring Meeting, Materials Research Society, San Francisco, April 18-

20, 1990 186, pp. 27-31 (Pittsburgh: Materials Research Society, 1991)

W. A. Shelton, Jr. Computational Physics, Inc., Annandale, Va.

F. J. Pinski. University of Cincinnati, Cincinnati, Ohio

D. D. Johnson. Sandia National Laboratory, Livermore, Calit.

D. M. Nicholson, G. M. Stocks. Oak Ridge National Laboratory, Oak Ridge, Tenn.

652 Crystal Growth and Deformation Behavior of TIAI Aluminides

ORNL/TM-11159 (April 1990)

B. F. Oliver, B. Y. Huang. University of Tennessee, Knoxville, Tenn.

W. C. Oliver. Oak Ridge National Laboratory, Oak Ridge, Tenn.

653 Energy Applications of High-Temperature Superconductivity

ER-6682, Volumes 1-2 (Palo Alto, Calif.: Electric Power Research Institute, 1990)

S. J. Dale. Oak Ridge National Laboratory, Oak Ridge, Tenn.

S. M. Wolf. Office of Conservation and Renewable Energy, U.S. Department of Energy, Washington, D. C.

T. R. Schneider. Electric Power Research Institute, Palo Alto, Calif.

654 Brittle Fracture and Grain Boundary Chemistry of Microalloyed NIAl J. Mater. Res., pp. 754-62 (1990)

E. P. George, C. T. Liu. Oak Ridge National Laboratory, Oak Ridge, Tenn.

655 The Effect of Processing on the Toughness of a Nickel Aluminide Alloy Scripta Met. 24, pp. 845-50 (1990)

D. J. Alexander. Oak Ridge National Laboratory, Oak Ridge, Tenn.

656 Brittle Fracture and Grain Boundary Chemistry of Microalloyed NIAI J. Mater. Res. 5, p. 754 (1990)

E. P. George, C. T. Liu. Oak Ridge National Laboratory, Oak Ridge, Tenn.

657 Temperature and Pressure Effects for Oxygen Adsorption and Oxidation of Ni3Al Alloyed with Chromlum and Zirconlum

Surface Science 225, pp. 195-205 (1990)

A. M. Venezia, C. M. Loxton. University of Illinois Urbana-Champaign, Champaign, III.

J. A. Horton. Oak Ridge National Laboratory, Oak Ridge, Tenn. 
658 Superplasticlty In an Ni3Al Base Alloy with 8 wt \% $\mathrm{Cr}$ J. Mater. Sci. 25(7), pp. 3142-48 (1990)

A. Choudhury, A. K. Mukherjee. University of Califomia, Davis, Calif.

V. K. Sikka. Oak Ridge National Laboratory, Oak Ridge, Tenn.

659 Ab Initlo Study of the Cu-Pd One-Dimensional Long Perlod Superstructure Phase Dlagram

Acta Metall. Mater. 38(11), pp. 2299-2308 (1990)

G. Ceder, D. de Fontaine. University of California, Berkeley, Calif.

H. Dreysse. Universite de Nancy, France

D. M. Nicholson, G. M. Stocks. Oak Ridge National Laboratory, Oak Ridge, Tenn

B. L. Gyortty. University of Bristol, United Kingdom

660 High Critical Current Densitles in YBa2 $\mathrm{Cu}_{3} \mathrm{O}_{7-x}$ Fllms on Polycrystalline Zirconla

Applied Physics Letters 57, pp. 1164 (1990)

D. P. Norton, D. H. Lowndes, J. D. Budai, D. K. Christen. Oak Ridge National Laboratory, Oak Ridge, Tenn.

E. C. Jones. University of Tennessee, Knoxville, Tenn.

K. W. Lay, J. E. Tksczyk. General Electric Company, Schenectady, N.Y.

661 Y-Ba-Cu-O Thin Films Grown on Rigid and Flexlble Polycrystalline YttrlaStabillzed Zirconia by Pulsed Laser Ablation

J. Applied Physics 68, pp. 223-27 (1990)

D. P. Norton, D. H. Lowndes, J. D. Budai, D. K. Christen. Oak Ridge National Laboratory,

Oak Ridge, Tenn.

J. W. McCamy, E. C. Jones. University of Tennessee, Knoxville, Tenn.

T. D. Ketcham, D. St. Julien. Corning, Corning, N.Y.

K. W. Lay, J. E. Tksczyk. General Electric Company, Schenectady, N.Y.

662 Selection of Corrosion-Resistant Materlals for Use in Molten Nitrate Salts ORNL/TM-11162 (October 1989)

P. F. Tortorelli, P. S. Bishop, J. R. DiStefano. Oak Ridge National Laboratory, Oak Ridge, Tenn.

663 An Investigation of Elastic Gulded Waves for Ceramic Jolnt Evaluation ORNL/TM-10931 (October 1989)

W. A. Simpson, Jr., R. W. McClung. Oak Ridge National Laboratory, Oak Ridge, Tenn.

664 High-Temperature Ordered Intermetallic Alloys III

ORNL/M-924 (August 1989)

C. T. Liu. Oak Ridge National Laboratory, Oak Ridge, Tenn.

A. I. Taub. General Electric Corp., Schenectady, N.Y.

N. S. Stoloff. Rensselaer Polytechnic Institute, Troy, N.Y.

C. C. Koch. North Carolina State University, Raleigh, N.C.

665 Alloy Development and Mechanical Propertles of Nickel Aluminide (N/3AI) Alloys

ORNL-6483 (August 1989)

C. T. Liu, V. K. Sikka, J. A. Horton, E. H. Lee. Oak Ridge National Laboratory, Oak Ridge, Tenn. 
666 Materlals by Design: Assessment of Theoretical and Experimental Tools for Applled Research and Exploratory Development in Certaln Energy Technologles

ORNL/Sub/86-00210/1 (February 1989)

R. W. Broach, R. A. Eades. Allied-Signal Engineered Materials, Des Plaines, III.

J. J. Low. University of Wisconsin, Milwaukee, Wis.

T. L. Barr. Consultant to ORNL, Toulumne, Calif.

J. W. Frazer. Oak Ridge National Laboratory, Oak Ridge, Tenn.

J. A. Carpenter, Jr. National Institute for Standards and Technology, Gaithersburg, Md.

667 Inorganic and Blomass-Derlved Plastics: Vlable Economic Alternatives to Petrochemical Plastics?

ORNLTM-10880 (February 1989)

T. R. Curlee. Oak Ridge National Laboratory, Oak Ridge, Tenn.

668 The Feaslbllity of Recycllng Plastlc Wastes: An Update Journal of Environmental Systems 18, pp. 193-212 (1989)

T. R. Curlee. Oak Ridge National Laboratory, Oak Ridge, Tenn.

669 Microstructures of N/3Al Alloys as a Function of $\mathrm{Cr}$ and Al Levels Proceedings of the 47th Annual Meeting, Electron Microscopy Society of America, San Antonio, Texas, August 6-11, 1989, pp. 306-307 (San Francisco: San Francisco Press, ivic., 1989)

J. A. Horton. Oak Ridge National Laboratory, Oak Ridge, Tenn.

670 Fabrication and Mechanical Propertles of $\mathrm{N}_{3} \mathrm{Al}-\mathrm{Al}_{2} \mathrm{O}_{3}$ Composites High-Temperature Ordered Intermetallic Alloys III: Symposium Held November 29 December 1, 1988, Boston, Massachusetts. Materials Research Society Symposia Proceedings 133, ed. C. T. Liu et al., Pp. 607-14 (Pittsburgh: Materials Research Society, 19839)

C. G. McKamey, J. A. Horton, T. N. Tiegs, E. K. Ohriner. Oak Ridge National Laboratory, Oak Ridge, Tenn.

G. L. Povirk. Brown University, Providence, R.I.

671 Structure Maps and Phase Stablilty In AlT/3 Alloyed with Rare-: ath Elements

High-Temperature Ordered Intermetallic Alloys III: Symposium Held November 29December 1, 1988, Boston, Massachusetts. Materials Research Society Symposia Proceedings 133, ed. C. T. Liu et al., pp. 37-43 (Pittsburgh: Materials Research Society, 1989)

C. T. Liu, J. A. Horton. Oak Ridge National Laboratory, Oak Ridge, Tenn.

D. G. Pettifor. Imperial College of Scies, ie and Technology, London, England

672 The Development of Alloys Based on $\mathrm{N}_{3} \mathrm{SI}$

High-Temperature Ordered Intermetallic Alloys III: Symposium Held November 29 December 1, 1988, Boston, Massachusetts. Materials Research Society Symposia Proceedings 133, ed. C. T. Liu et al., pp. 397-402 (Pittsburgh: Materials Research Society, 1989)

W. C. Olivei: Oak Ridge National Laboratory, Oak Ridge, Tenn.

673 Applications of the Quadratic Korringa-Kohn-Rostoker Band-Theory Method

Phys. Rev. B 39, pp. 8187-92 (1989)

D. M. Nicholson. Oak Ridge National Laboratory, Oak Ridge, Tenn.

j. S. Faulikner. Florida Atlantic University, Boca Raton, Fla. 
674 Analysis of Heat-Affected Zone Cracking In N/3Al Alloy Welds by Computer Modellng of Thermal Stresses

Welding J. 68(1), pp. 19s-27s (1989)

M. L. Santella, S. A. David. Oak Ridge Nilional Laboratory, Oak Ridge, Tenn.

M. C. Maguire. Colorado School of Mines, Golden, Colo.

675 Chemical Vapor Deposition in the Sillcon-Carbon and Boron-CarbonNitrogen Systems

ORNLTM-10884 (November 1988)

T. M. Besmann. Oak Ridge National Laboratory, Oak Ridge, Tenn.

676 Assessment of the State of the Art in Machining and Surface Preparation of Ceramics

ORNLTM-10791 (November 1988)

D. P. Stinton. Oak Ridge National Laboratory, Oak Ridge, Tenn.

677 A Prellminary Study of the Use of Magnetohydrodynamic Forces to Remove Impuritles from Molten Metals

ORNL/TM-10747 (June 1988)

D. O. Hobson. Oak Ridge National Laboratory, Oak Ridge, Tenn.

678 Welding Behavior and Mlcrostructure of an N/3Al Alloy

Weld. Res. Suppl., pp. 63s-69s (March 1988)

M. L. Santella, J. A. Horton, S. A. David. Oak Ridge National Laboratory, Oak Ridge, Tenn.

679 Development of Nickel and Nickel-Iron Aluminides for ElevatedTemperature Structural Use

MiCon 86: Optimization of Processing, Properties, and Service Performance Through Microstructural Control, ed. B. L. Bramfitt et al., pp. 222-37. ASTM Special Technical Publication 979 (Philadelphia: American Society for Testing and Materials, February 1988)

C. T. Lia. Oak Ridge National Laboratory, Oak Ridge, Tenn.

680 Assessment of Materlal Requirements for Advanced Steam Cycle Systems $\left(>1100^{\circ} \mathrm{F}\right)$

ORNLTM-10489 (February 1988)

J. R. DiStefano, J. H. DeVan, L. C. Fuller. Oak Ridge National Laboratory, Oak Ridge, Tenn.

681 Initial Development of High-Temperature Titanium Silicide Alloys ORNL-6435 (January 1988)

C. T. Liu, E. H. Lee, T. J. Henson. Oak Ridge National Laboratory, Oak Ridge, Tenn.

682 Effect of Chromlum on Early Stages of Oxidation of N/3Al Alloys at $600^{\circ} \mathrm{C}$ Oxid. Met. 29(3/4), pp. 347-65 (1988)

J. A. Horton, J. V. Cathcart, C. T. Liu. Oak Ridge National Laboratory, Oak Ridge, Tenn.

683 Englneering Processing and Propertles of Nickel Aluminides Proceedings of Second International SAMPE Metals and Metals Processing Conference, Dayton, Ohio, August 2-4, 1938, Volume 2: Space Age Metals Technology, ed. F. H. Froes and R. A. Cull, pp. 62-75 (Covina, Calif.: Society for the Advancement of Material and Process Engineering, 1988)

V. K. Skka. Oak Ridge National Laboratory, Oak Ridge, Tenn. 
684 Innovations In Materlals and Materlals Processing: The Potential for Energy Conservation Materials and Society 12, pp. 1-45 (1988)

T. R. Curlee. Oak Ridge National Laboratory, Oak Ridge, Tenn.

685 Applications of Thermochemical Modeling to Chemical Vapor Deposition Processes

Surface Modification Technologies. Proceedings of the First International Symposium, Phoenix, Arizona, January 1988, ed. T. S. Sudarshan and D. G. Bhat, pp. 311-25 (New York: The Metallurgical Society, 1988)

T. M. Besmann. Oak Ridge National Laboratory, Oak Ridge, Tenn.

686 The Role of Interfaclal Reactions on the Mechanical Properties of Ceramic Brazements

Ceramic Microstructures '86: Role of Interfaces, Proceedings of the Symposium,

Berkeley, Califomia, July 28-31, 1986, ed. J. A. Pask and A. G. Evans. Materials Science

Research 21, pp. 949-58 (New York: Plenum Publishing Corp., 1988)

A. J. Moornead, H. M. Henson, T. J. Henson. Oak Ridge National Laboratory, Oak Ridge, Tenn.

687 A Technique for Preparing Cross Section TEM Specimens from Ceramic Oxide Braze Jolnts

Journal of Electron Microscopy Technique 8, pp. 211-15 (1988)

M. L. Santella, A. T. Fischer, C. P. Haltom. Oak Ridge National Laboratory, Oak Ridge,

Tenn.

688 Hardening Behavlor of Nickel Beryllides

Scr. Metall. 22(9), pp. 1409-13 (1988)

T. G. Nieh, J. Wadsworth. Lockheed Research and Development Division, Palo Alto,

Calit.

C. T. Liu. Oak Ridge National Laboratory, Oak Ridge, Tenn.

689 Applicability of Aerospace Thermal Insulation Technologles to the Clvillan Sector

ORNL/Sub/86-55951/1 (October 1987)

H. A. Fine. University of Kentucky, Lexington, Ky.

690 Plastics Recycling Faces Barrlers

Waste Age 18(7), pp. 55-60 (July 1987)

T. R. Curlee. Oak Ridge National Laboratory, Oak Ridge, Tenn.

691 Ultrasonic Technlques for the Evaluation of Ceramic Jolnts ORNL-6350 (April 1987)

W. A. Simpson, Jr., R. W. McClung. Oak Ridge National Laboratory, Oak Ridge, Tenn.

692 Annua! Progress Report of the Materlals Project of the Energy Conversion and Utilization Technologies (ECUT) Program for FIscal Year 1983

ORNLTM-9695 (February 1987)

L. E. Morris, A. Jordan, J. A. Carpenter, Jr. Oak Ridge National Laboratory, Oak Ridge, Tenn.

693 Development of a Test for Determining Fracture Toughness of Brazed Jolnts in Ceramic Materlals

Weld. J. 66, pp. 26s-32s (January 1987)

A. J. Mioornead, F. F. Becher. Oak Fiioge Nationai Laboratory, Oak Fidge, Tenn. 
694 Adaptation of DCB Test for Determining Fracture Toughness of Brazed Jolnts In Ceramic Materlals

J. Mater. Sci. 22(9), pp. $3297-3303$ (1987)

A. J. Moorhead, P. F. Becher. Oak Ridge National Laboratory, Oak Ridge, Tenn.

695 Direct Brazing of Alumina Ceramics

Adv. Ceram. Mater. 2(2), pp. $159-66$ (1987)

A. J. Moorhead. Oak Ridge National Laboratory, Oak Ridge, Tenn.

696 Processing Technology for Nickel Aluminides

Proceedings of the Materials Research Society Symposium, Boston, December 1-6, 1986, 81, pp. 487-93 (Pittsburgh: Materials Research Society, 1987)

V. K. Sikka. Oak Ridge National Laboratory, Oak Ridge, Tenn.

697 Secondary Reclamation of Plastics Waste Research Report Phase II. Evaluation of Industrlal Processes: Financlal Analysis and Potentlal Markets

Lancaster, Pa.: Technomic Publishing Co., Inc., 1987

Plastics Institute of America, Inc. Hoboken, N.J.

698 Secondary Reclamatlon of Plastlcs Waste Research Report Phase I. Development of Techniques for Preparation and Formulation

Lancaster, Pa.: Technomic Publishing Co., Inc., 1987

Plastics Institute of America, Inc. Hoboken, N.J. 


\section{TRIBOLOGY}

699 Relating Laboratory Friction Coefficlent Values to Practical Applications Proceodings of the Annual Automotive Technology Development Contractors' Coordination Meeting 1991 P-256, pp. 571-77 (Warrendale, Pa.: Society of Automotive Engineers, June 1992)

P. J. Blau. Oak Ridge National Laboratory, Oak Ridge, Tenn.

700 Wear Mode Transition In a Sillcon Nitride-SIIIcon Carbide Whisker Composite

Proceedings of the Annual Automotive Technology Development Contractors' Coordination Meeting 1991 P-256, pp. 579-86 (Warrendale, Pa.: Society of Automotive Engineers, June 1992)

C. S. Yust. Oak Ridge National Laboratory, Oak Ridge, Tenn.

701 Wear-Resistant Materlals

Advanced Materials and Processes Technological Forecast Issue, pp. 25-26 (January 1990)

P. J. Blau. Oak Ridge National Laboratory, Oak Ridige, Tenn.

702 Sliding Friction and Wear Behavior of Nickel Aluminide Alloys Trib. International 23(4), pp. 226-34 (1990)

P. J. Blau, C. E. DeVore. Oak Ridge National Laboratory, Oak Ridge, Tenn.

703 Friction Microprobe Studles of Composite Surfaces

Tribology of Composite Materials, pp. 59-68 (Materials Park, Ohio: ASM Intemational, 1990)

P. J. Blau. Oak Ridge National Laboratory, Oak Ridge, Tenn.

704 Friction and Wear of Whisker-Relnforced Ceramic Composite Materlals Tribology of Composite Materials, P. 25-33 (Materials Park, Ohio: ASM Intemational, 1990)

C. S. Yust. Oak Ridge National Laboratory, Oak Ridge, Tenn.

705 Morphological Aspects of the Friction of Hot-Fllament Grown Dlamond Thin Films

Mechanics of Coatings, pp. $399-408$ (Elsevier Publ., 1990)

P. J. Blau, C. S. Yust, L. J. Heatherly, R. E. Clausing. Oak Ridge National Laboratory, Oak Ridge, Tenn.

70 Elastic Behavior of Coated Rough Surfaces Mechanics of Coatings, pp. 157-68 (Elsevier Publ., 1990)

J. I. McCool. MRC-SKF Aerospace, King of Prussia, Pa.

707 A Study of the Trlbological and Surface Micromechanical Properties of YBa $\mathrm{Cu}_{3} \mathrm{O}_{7-x}$. Final Report

ORNLTM-11053 (July 1989)

P. J. Blau, C. E. DeVore, D. F. Wilson, J. R. Keiser. Oak Ridge National Laboratory, Oak Ridge, Tenn.

708 Friction and Wear Transitions of Materlals: Break-In, Run-In, and Wear-In Park Ridge, N.J.: Noyes Publications, 1989

P. J. Blau. Oak Ridge National Laboratory, Oak Ridge, Tenn. 
709 The Units of Wear Revisited

Lubrication Engineering 45, p. 609 (1989)

P. J. Blau. Oak Ridge National Laboratory, Oak Ridge, Tenn.

710 Temperature Effects on the Ereak-In of NIckel Aluminide Alloys

Proceedings International Conference cin Wear of Materials, Denver, Colo., April 8-11, 1989, ASME Book No. H0456A, Vol. 1, pp. 305-12 (New York: American Society of Mechanical Engineers, 1989)

P. J. Blau, C. E. DeVore. Oak Ridge National Laboratory, Oak Ridge, Tenn.

711 Interpretations of the sliding Friction Break-In Curves of AluminaAluminum Couples Wear 129, pp. 81-92 (1989)

P. J. Blau, C. E. DeVore. Oak Ridge National Laboratory, Oak Ridge, Tenn.

712 Development of a Theory of Wear of Ceramics. Final Report ORNLSUb/84-7802/1 (July 1988)

W. O. Winer, B.-Y. Ting. Georgia Institute of Technology, Atlanta, Ga.

713 A Thermomechanical Wear Theory

Ph.D. Dissertation, Georgia Institute of Technology, Atlanta, Ga., May 1988

B.-Y. Ting. Georgia Institute of Technology, Atlanta, Ga.

714 Development of X-Ray Methods for Analyzing Rough-Wear Surfaces on Ceramics. Technical Summary of Completed ORNL Subcontract 19B$07733 B$

ORNLTM-10710 (May 1988)

P. J. Blau. Oak Ridge National Laboratory, Oak Ridge, Tenn.

715 A Comparison of Methods for Determining Wear Volumes and Surface Parameters of Spherically Tipped Silders

Wear 124, pp. 291-309 (1988)

E. P. Whitenton. National institute of Standards and Technology, Gaithersburg, Md.

P. J. Blau. Oak Ridge National Laboratory, Oak Ridge, Tenn.

716 Initial Frictlonal Behavior During the Wear of Steel, Aluminum, and Poly(Methylmethacrylate)

Wear 124, pp. 1-20 (1988)

P. J. Blau. Oak Ridge National Laboratory, Oak Ridge, Tenn.

E. P. Whitenton, A. Shapiro. National Institute of Standards and Technology, Gaithersburg, Md.

717 Selection and Use of Wear Testing Methods for Ceramics

ASTM Special Technical Publication 1010 (Philadelphia: American Society for Testing and Materials, 1988)

C. S. Yust, ed. Dak Ridge National Laboratory, Oak Ridge, Tenn.

R. G. Bayer, ed. IBM Corp., Endicott, N.Y.

718 The Distrlbution of Microcontact Area, Load, Pressure, and Flash Temperature Under the Greenwood-Williamson Model

J. Trib. 110, p. 106 (1988)

J. I. McCool. MRC-sKF Aerospace, King of Prussia, Pa. 
719 A Study of the Friction and Wear-Related Propertles of Ceramlc Superconductors

Engineered Materials for Advanced Friction and Wear Applications, ed. F. Smidt and P. J. Blau, pp. 231-41 (Metals Park, Ohio: ASM International, 1988)

P. J. Blau, C. E. DeVore. Oak Ridge National Laboratory, Oak Ridge, Tenn.

720 Englneered Materials for Advanced Frictlon and Wear Appllcatlons

Metals Park, Ohio: ASM International, 1988

P. J. Blau, ed. Oak Ridge National Laboratory, Oak Ridge, Tenn.

F. Smidt, ed. Naval Research Laboratory, Washington, D.C.

721 Resldual Straln Gradlents In a Fully Stabillzed Zirconla Sample

J. Appl. Phys. 63(11), pp. 5351-56 (1988)

B. Hwang, C. R. Houska. Virginia Polytechnic Institute and State University, Blacksburg, Va.

G. E. Ice, A. Habenschuss. Oak Ridge National Laboratory, Oak Ridge, Tenn.

722 Calculation of X-Ray Intensity from a Rough Sample Based on a Siatistical Model

J. Appl. Phys. 63(11), pp. 5346-50 (1988)

B. Hwang, C. R. Houska. Virginia Polytechnic Institute and State University, Blacksburg, $\mathrm{Va}$.

723 X-Ray Analysis of the Near-Surface Phase Distribution Applled to Wear on a PSZ DIsk

Adv. Ceramic Materials 3(2), pp. 180-83 (1988)

B. Hwang, C. R. Houska. Virginia Polytechnic Institute and State University, Blacksburg, Va.

G. E. Ice, A. Habenschuss. Oak Ridge National Laboratory, Oak Ridge, Tenn.

724 Sllding Behavior of Alumina/Nickel and Alumina/Nickel Aluminide Couples at Room and Elevated Temperature

Journal of Tribology 110(4), pp. 646-52 (1988)

P. J. Blau, C. E. DeVore. Oak Ridge National Laboratory, Oak Ridge, Tenn.

725 Near Surface Wear Structure of Ceramics

Ph.D. Dissertation, Virginia Polytechnic Institute and State University, Blacksburg, Va., May 1987

B.-H. Hwang. Virginia Polytechnic Institute and State University, Blacksburg, Va.

726 A Proposed Thermomechanlcal Wear Theory Approaches to Modeling Friction and Wear, ed. F. F. Ling (New York: Springer Verlag, 1987)

B.-Y. Ting, W. O. Winer. Georgia Institute of Technology, Atlanta, Ga.

727 An Experimental Study of the Hot Spots Occurring Durlng the Oxidational Wear of Tool Steel on Sapphire

J. Tribology 109(2), pp. 315-20 (1987)

T. F. J. Quinn, W. O. Winer. Georgia Institute of Technology, Atlanta, Ga.

728 Wear of an Alumina-Sillicon Carblde Whisker Composite Wear Mater. 1, pp. 277-83 (1987)

C. S. Yust, J. M. Leitnaker, C. E. DeVore. Oak Ridge National Laboratory, Oak Ridge, Tenn. 


\section{ENERGY-RELATED INVENTIONS PROGRAM}

729 Government Promotion of Energy Innovations: An Evaluation of the Energy-Related Inventlons Program

Policy Studies Journal 20(1), pp. 87-101 (1992)

M. A. Brown. Oak Ridge National Laboratory, Oak Ridge, Tenn.

C. R. Wilson. University of Tennessee, Knoxville, Tenn.

730 The Energy-Related Inventions Program: A Decade of Commerclal Progress

ORNLCON-339 (December 1991)

M. A. Brown, C. A. Franchuk. Oak Ridge National Laboratory, Oak Ridge, Tenn.

C. R. Wilson. University of Tennessee, Knoxville, Tenn.

731 Guidellnes for Successfully Transferring Government-Sponsored Innovations

Research Policy 20(2): pp. 121-43 (April 1991)

M. A. Brown, L. G. Berry, R. K. Goel. Oak Ridge National Laboratory, Oak Ridge, Tenn.

732 The Energy-Related Inventions Program: Commerclal Progress of Particlpants Through 1988

ORNL/CON-301 (May 1990)

M. A. Brown. Oak Ridge National Laboratory, Oak Ridge, Tenn.

C. R. Wilson. University of Tennessee, Knoxville, Tenn.

733 The Cost of Commerclallzing Energy Inventions

Research Policy 19(2), pp. 147-55 (1990)

M. A. Brown. Oak Ridge National Laboratory, Oak Ridge, Tenn.

734 Promoting the Commerclalization of Energy Innovations: An Evaluation of the Energy-Related Inventions Program

Proceedings of the National Energy Program Evaluation Conference, Chicago, August 23-25, 1989, pp. 33-38 (Argonne, III.: Argonne National Laboratory, August 1989)

M. A. Brown. Oak Ridge National Laboratory, Oak Ridge, Tenn.

735 Commerclalizing Government-Sponsored Innovatlons: Twelve Successful Bulldings Case Studles

ORNL/C.ON-275 (January 1989)

M. A. Brown, L. G. Berry, R. K. Goel. Oak Ridge National Laboratory, Oak Ridge, Tenn.

736 The Energy-Related inventions Program: An Assessment of Recent Commerclal Progress

ORNL/CON-252 (October 1988)

M. A. Brown. Oak Ridge National Laboratory, Oak Ridge, Tenn.

S. A. Snell. University of Tennessee, Knoxville, Tenn.

737 The Commerclallzation Process and Future Energy Options

Proceedings of the International Symposium on Energy Options for the Year 2000:

Contemporany Concepts in Technology and Policy, Wilmington, Delaware, September 14-17, 1988 2, pp. 225-34 (Newark, Delaware: Center for Energy and Urban Policy Research, University of Delaware, 1988)

M. A. Brown. Oak Ridge National Laboratory, Oak Ridge, Tenn.

S. A. Snell. University of Tennessee, Knoxville, Tenn. 
738 Evaluation of the Energy-Related Inventions Program: An Empirical Analysis of 204 Inventions

ORNL/CON-225 (March 1987)

M. A. Brown, J. A. Morell, E. J. Soderstrom. Oak Ridge National Laboratory, Oak Ridge, Tenn.

S. Snell. University of Kentucky, Lexington, Ky.

W. Friggle. Consultation Systems, Inc., Philadelphia, Pa. 


\section{ELECTRIC ENERGY SYSTEMS}

739 Recommended Engineering Practice to Enhance the EMIIEMP Immunity of Electric Power Systems

ORNL/Sub/91-SG913/1 (December 1992)

C. L. Wagner. Department of Energy, Washington, D. C.

W. E. Feero. Electric Research and Management, Inc., State College, Pa.

740 Proceedings, Workshop on Real-Time Control and Operation of Electric Power Systems, November 19-21, 1991, Denver, Colorado

CONF-9111173 (Oak Ridge, Tenn.: Oak Ridge National Laboratory, July 1992)

D. T. Rizy, ed. Oak Ridge National Laboratory, Oak Ridge, Tenn.

W. E. Myers, ed. Bonneville Power Administration, Portland, Ore.

L. E. Eilts, C. L. Clemans. Westem Area Power Administration, Golden, Colb.

741 Experimental Investigation of Steep-Front, Short Duration (SFSD) Surge Effects on Power Systems Components

ORNL/Sub/87-91345 (May 1992)

D. B. Miller. Mississippi State University, Mississippi State, Miss.

742 Mitigation of Magnetohydrodynamic Electromagnetlc Pulse (MHD.EMP) Effects from Commerclal Electric Power Systems

ORNL-6709 (March 1992)

P. R. Bames. Oak Ridge National Laboratory, Oak Ridge, Tenn.

F. M. Tesche, E. F. Vance. Consultants to Oak Ridge National Laboratory, Oak Ridge, Tenn.

743 HEMP-Induced Translents In Electric Power Substations

ORNL/Sub/88-SC863 (February 1992)

C. M. Wiggins, D. F... Thomas, T. M. Salas. BDM Intemational Inc., Albuquerque, N. Mex.

744 An Approach to Metering and Network Modelling

Proceodings of the American Power Conference 54-1I, pp. 1068-74 (Chicago: Illinois Institute of Technology, 1992)

M. M. Adibi. IRD Corporation, Bethesda, Md.

K. A. Clements. Worcester Polytechnic Institute, Worcester, Mass.

R. J. Kafka. Potomac Electric Power Company, Washington, D. C.

J. P. Stovall. Oak Ridge National Laboratory, Oak Ridge, Tenn.

745 Transient Electric and Magnetic Flelds Assoclated with Establishing a Finite Electrostatic Lilpole, Revisited

IEEE Transactions on Electromagnetic Compatibility 33(4), pp. 312-20 (November 1991)

M. Rubinstein, M. A. Uman. University of Florida, Gainesville, Fla.

746 Malntalning Electric Power System Performance: Preparing for the Year 2020 Research Needs

ORNL-6678 (November 1991)

S. J. Dale, J. P. Stovall. Oak Ridge National Laboratory, Oak Ridge, Tenn.

K. W. Klein. Department of Energy, Washington, D. C. 
747 Electric UtIIIty Industry Experience with Geomagnetlc Disturbances

ORNL-6665 (September 1991)

P. R. Bames, D. T. Rizy, B. W. McConnell. Oak Ridge National Laboratory, Oak Ridge, Tenn.

F. M. Tesche. Consultant to Oak Ridge National Laboratory, Oak Ridge, Tenn.

E. R. Taylor, Jr. ABB Power Systems, Inc., Pittsburgh, Pa.

748 EMP Research on Electric Power Systems. Program Update ORNLM-1392 (May 1991)

P. R. Bames. Oak Ridge National Laboratory, Oak Ridge, Tenn.

749 Assessment of Conducting Polymer Applicatlons in Power Equipment Technology

ORNL/Sub/87-SA681/1 (May 1991)K. F. Schoch, Jr., A. I. Bennett, R. R. Burghardt, A.

H. Cookson, H. E. Saunders, J. D. B. Smith. Westinghouse Electric Corp., Pittsburgh, $\mathrm{Pa}$.

W. N. Kennedy. ABB Power Transmission \& Distribution Co., Pittsburgh, Pa.

T. V. Oommen. ABB Power Transmission \& Distribution Co., Sharon, $\mathrm{Pa}$.

R. E. Voshall. Gannon University, Erie, Pa.

E. M. Fort. Westinghouse Electric Corp., Orlando, Fla.

B. Robbins. Reynolds Metals Co., Richmond, Va.

750 Impacts of a Nominal Nuclear Electromagnetlc Pulse on Electric Power Systems. Phase III Final Report

ORNL/Sub/83-43374/2 (April 1991)

V. J. Kruse, D. L. Nickel, J. J. Bonk, E. R. Taylor, Jr. ABB Power Systems, Inc., Advanced

Systems Technology, Pittsburgh, $\mathrm{Pa}$.

751 Impact of Steep-Front Short-Duration Impulse on Electric Power System Insulation. Phase 11: Laboratory Evaluation of Selected Power System Components

ORNL/Sub/85-28611/2 (April 1991)

L. M. Burrage, E. F. Veverka, J. H. Shaw. Cooper Power Systems, Franksville, Wis.

B. W. McConnell. Oak Ridge National Laboratory, Oak Ridge, Tenn.

752 System Reconflguration Analysis Program (SYSRAP) User's Manual

ORNL-6575 (April 1991)

J. B. Patton. Consultant to Oak Ridge National Laboratory, Oak Ridge, Tenn.

D. T. Rizy. Oak Ridge National Laboratory, Oak Ridge, Tenn.

J. S. Lawler. University of Tennessee, Knoxville, Tenn.

753 On Estimation of Uncertaintles In Analog Measurements

IEEE Trans. Power Systems 5(4), pp. 1222-28 (November 1990)

M. M. Adibi. Consultant to Oak Ridge National Laboratory, Oak Ridge, Tenn.

J. P. Stovall. Oak Ridge National Laboratory, Oak Ridge, Tenn.

754 Induced Voltage on an Overhead Line Due to Nearby Lightning

IEEE Trans. Eloctromagnetic Compatibility 32(4), pp. 292-99 (November 1990)

G. Diendorfer. Technical University, Vienna, Austria

755 An improved Return Stroke Model with Speclfied Channel-Base Current Journal of Geophysical Research 95(D9), pp. 13,621-44 (August 20, 1990)

G. Diendorfer. Technical University, Vienna, Austria

M. A. Uman. University of Florida, Gainesville, Fla. 
756 Updated Evaluation of Polymer Fllms for Electrical Insulation ORNL-6603 (August 1990)

H. E. McCoy, Jr. Oak Ridge National Laboratory, Oak Ridge, Tenn.

757 Polarization Currents In Varistors

J. Appl. Phys. 68(1), pp. 339-45 (July 1990)

F. A. Modine. Oak Ridge National Laboratory, Oak Ridge, Tenn.

R. W. Major. University of Richmond, Va.

S.-I. Choi, L. B. Bergman, M. N. Silver. University of North Carolina, Chapel Hill, N.C.

758 Transient Response of a Distribution Circult Recloser and Control Unit to a High-Altitude Electromagnetlc Pulse (HEMP) and Lightning

IEEE Trans. Electromagnetic Compatibility 32(2), pp. 113-24 (May 1990)

P. R. Bames. Oak Ridge National Laboratory, Oak Ridge, Tenn.

F. M. Tesche. Consultant to Oak Ridge National Laboratory, Oak Ridge, Tenn.

759 Pulse Response Characteristics of Zno Varlstors

J. Appl. Phys. 67(10), pp. 6560-66 (May 1990)

F. A. Modine. Oak Ridge National Laboratory, Oak Ridge, Tenn.

R. B. Wheeler. Los Alamos National Laboratory, Los Alamos, N. Mex.

760 Load Flow Studies in the Presence of Magnetohydrodynamic

Electromagnetic Pulse

IEEE Trans. Power Delivery 5(2), pp. 1158-63 (April 1990)

V. J. Kruse, G. B. Rackcliffe. Westinghouse Electric Corp., Pittsburgh, Pa.

P. R. Bames. Oak Ridge National Laboratory, Oak Ridge, Tenn.

761 Applications Software for Modeling Distribution Automation Operations on the Athens Utillties Board

IEEE Trans. Power Delivery 5(2), pp. 1019-25 (April 1990)

J. B. Patton. Consultant to Oak Ridge National Laboratory, Oak Ridge, Tenn.

D. T. Rizy. Oak Ridge National Laboratory, Oak Ridge, Tenn.

J. S. Lawler. University of Tennessee, Knoxville, Tenn.

762 Flashover Vulnerablilty of Transmission and Distribution Lines to HighAltitude Electromagnetlc Pulse (HEMP)

IEEE Trans. Power Deliveny 5(2), pp. 1164-69 (April 1990)

V. J. Kruse. Westinghouse Electric Corp., Pittsburgh, Pa.

P. R. Bames. Oak Ridge National Laboratory, Oak Ridge, Tenn.

F. M. Tesche. Consultant to Oak Ridge National Laboratory, Oak Ridge, Tenn.

763 The Effects of Steep-Front Short-Duration Impulses on Power Distribution Component

IEEE Trans. Power Delivery 5(2), pp. 708-15 (April 1990)

D. B. Miller, A. E. Lux, S. Grzybowski. Mississippi State University, Mississippi State, Miss.

P. R. Bames. Oak Ridge National Laboratory, Oak Ridge, Tenn.

764 On the Radlation Fleld Turn-on Term Assoclated with Travelling Current Discontinulties in Lightning

Joumal of Geophysical Research 95(D4), pp. 3711-13 (March 1990)

M. Rubinstein, M. A. Uman. University of Florida, Gainesville, Fla. 
765 Analysls of Power Sector Efflciency Improvements for an Integrated UtIIIty Planning Process in Costa Rica

Proceedings 25th Intersociety Energy Conversion Engineering Conference 4, pp. 38692 (New York: American Institute of Chemical Engineers, 1990)

D. B. Waddle, J. M. MacDonald. Oak Ridge National Laboratory, Oak Ridge, Tenn.

766 Measurement of Partial Discharges in Hexane Under DC Voltage IEEE Trans. Electr. Insul. 24, pp. 1109-19 (December 1989)

E. F. Kelley, M. Nehmadi, R. E. Hebner. National Institute for Standards and Testing, Gaithersburg, Md.

M. O. Pace, A. L. Wintenberg, T. V. Blalock, J. V. Foust. University of Tennessee, Knoxville, Tenn.

767 Integrated Hlerarchical Computer Systems for Adaptive Protective Relaying and Control of Electric Transmission Power Systems ORNL/SUb/85-22005/1 (November 1989)

A. G. Phadke. Virginia Polytechnic Institute and State University, Blacksburg, Va.

S. H. Horowitz. American Electric Power Company, Inc., Columbus, Ohio

J. S. Thorp. Cornell University, thaca, N.Y.

768 Adaptive Protective Relaying of Transmission Power Systems for Improved Rellabllity

ORNL/Sub/85-22012/1 (September 1989)

G. D. Rockefeller, R. T. Byerly, W. E. Feero, C. L. Wagner. Electric Research and Management, Inc., State College, $\mathrm{Pa}$.

K. L. Hicks. Stone \& Webster Engineering Corp., Boston, Mass.

J. R. Linders. Consultant to Oak Ridge National Laboratory, Oak Ridge, Tenn.

J. Nichol. A. D. Little, Inr., Cambridge, Mass.

769 HEMP TESt and Analysis of Selected Recloser-Control Units ORNL/Sub/88-00238/1 (August 1989)

T. K. Liu, S. H. Sands. LuTech, Inc., Oakland, Calif.

F. M. Tesche. E-Systems, Inc., Greeneville, Texas

P. R. Bames. Oak Ridge National Laboratory, Oak Ridge, Tenn.

770 Zinc OxIde Varlstor Response TIme

Proceedings of the Second International Varistor Conference on Zinc Oxide Varistors:

Science and Technology, Schenectady, New York, December 5-7, 1988 3, pp. 176-85

(Westerville, Ohio: American Ceramic Society, 1989)

F. A. Modine. Oak Ridge National Laboratory, Oak Ridge, Tenn.

R. W. Major. University of Richmond, Richmond, Va.

S.-I. Choi, L. B. Bergman, M. N. Silver. University of North Carolina, Chapel Hill, N.C.

771 Automating Electric Utility Distribution Systems: The Athens Automation and Control Experiment

New York: Prentice Hall, 1989

P. A. Gnadt, J. S. Lawler. Consultants to Oak Ridge National Laboratory, Oak Ridge, Tenn.

772 The HEMP Response oi an Overhead Power Distribution LIne

IEEE Trans. Power Delivery 4, pp. 1937-44 (1989)

F. M. Tesche. E-Systems, Inc., Greeneville, Texas

P. R. Bames. Oak Ridge National Laboratory, Oak Ridge, Tenn. 


\section{Analysis of Water Heater Data from Athens Load Control Experiment} IEEE Trans. Power Delivery 4, pp. 1232-38 (1989)

J. H. Reed. Oak Ridge National Laboratory, Oak Ridge, Tenn.

J. C. Thompson, R. P. Broadwater, A. Chandrasekaran. Tennessee Technological

University, Cookeville, Tenn.

774 Pulsed Charge Transport in Polycrystalline Zinc Oxlde

Bulletin of the American Physical Society 34, p. 999 (1989)

J. F. Cordaro. Alfred University, Alfred, N.Y.

F. A. Modine. Oak Ridge National Laboratory, Oak Ridge, Tenn.

775 The Induced Current in Parallel Wires Over an Imperfect Ground From an Incident EMP

Proceedings 1989 Southeastcon, IEEE Regional Meeting, University of South Carolina, Columbia, S.C., April 1989, Vol. 2 (New York: IEEE, 1989)

H. P. Neff, Jr. University of Tennessee, Knoxville, Tenn.

D. A. Reed. Consultant to Oak Ridge National Laboratory, Oak Ridge, Tenn.

776 Spark Decomposition of SF 6 : Chemical and Blological Studies IEEE Trans. Power Delivery 4, pp. 1541-551 (1989)

G. D. Griffin, I. Sauers, C. E. Easterly. Oak Ridge National Laboratory, Oak Ridge, Tenn.

K. Kurka. University of Tennessee, Knoxville, Tenn. 777 Distribution Automation Applications Soffware for the Athens UtIllties
Board

IEEE Trans. Power Delivery 4, pp. 715-24 (1989)

D. T. Rizy. Oak Ridge National Laboratory, Oak Ridge, Tenn.

J. S. Lawler. University of Tennessee, Knoxville, Tenn.

J. B. Patton. Consultant to Oak Ridge National Laboratory, Oak Ridge, Tenn.

N. H. Fortson. Athens Utilities Board, Athens, Tenn.

778 Impact of Automation on the Rellabillty of the Athens UtIlltes Board's Distribution System

IEEE Trans. Power Delivery 4, pp. 770-78 (1989)

L. D. Monteen. Athens Utilities Board, Athens, Tenn.

J. S. Lawler, J. S. Lai. University of Tennessee, Knoxville, Tenn.

J. B. Patton. Consultant to Oak Ridge National Laboratory, Oak Ridge, Tenn.

D. T. Rizy. Oak Ridge National Laboratory, Oak Ridge, Tenn.

779 A Multiconductor Model for Determining the Response of Power Transmission and Distribution Lines to a High Altitude Electromagnetic
Pulse (HEMP)

IEEE Trans. Power Delivery 4, pp. 1955-64 (1989)

F. M. Tesche. E-Systems, Inc., Greeneville, Texas

P. R. Bames. Oak Ridge National Laboratory, Oak Ridge, Tenn.

780 Steep Front-Short Duration Voltage Surge Tests of Power Line Filters and Translent Voltage Suppressors

IEEE Trans. Power Delivery 4. pp. 1029-36 (1989)

P. R. Barnes, T. L. Hudson. Odk Ridge National Laboratory, Oak Ridge, Tenn.

781 Instrumentation System Used to Determine the Effects of Steep FrontShort Duration Impulses on Electric Power System Insulation

IEEE Trans. Power Delivery 4, pp. 938-41 (1989)

J. H. Shaw. McGraw-Edison Power Systems, Franksville, Wis. 
782 Experlmental Deternilnation of the Effects of Steep Front-Short Duration Surges on 25 KVA Pole Mounted Distrlbution Transformers

IEEE Trans. Power Delivery 4, pp. 1103-10 (1989)

C. H. Eichler, J. R. Legro. Westinghouse Electric Corp., Pittsburgh, Pa.

P. R. Bames. Oak Ridge National Laboratory, Oak Ridge, Tenn.

783 Measuring and Analyzing the Impact of Voltage and Capacitor Control with High Speed Data Acquisition

IEEE Trans. Power Delivery 4, pp. 704-14 (1989)

D. T. Rizy, W. R. Nelson. Oak Ridge National Laboratory, Oak Ridge, Tenn.

J. S. Lawler. University of Tennessee, Knoxville, Tenn.

J. B. Patton. Consultant to Oak Ridge National Laboratory, Oak Ridge, Tenn.

784 Monitoring Load Control at the Feeder Level Using High Speed Monitoring Equipment

IEEE Trans. Power Delivery 4, pp. 694-703 (1989)

J. H. Reed, W. R. Nelson, G. R. Wetherington, E. R. Broadaway. Oak Ridge National

Laboratory, Oak Ridge, Tenn.

785 The Origin of the Pulse Response Characteristics of Zine Oxide Varistors J. Appl. Phys. 66, pp. 5608-12 (1989)

F. A. Modine, R. B. Wheeler. Oak Ridge National Laboratory, Oak Ridge, Tenn.

Y. Shim, J. F. Cordaro. Affred University, Aftred, N.Y.

786 Load Control Experiments With Heat Pumps During the Winter

IEEE Trans. Power Delivery 4, pp. 646-52 (1989)

J. H. Reed. Oak Ridge National Laboratory, Oak Ridge, Tenn.

R. P. Broadwater, A. Chandrasekaran. Tennessee Technological University, Cookeville, Tenn.

787 Transmission LIne Design Provides Optlons

Transmission and Distribution Magazine, pp. 38-40 (October 1988)

J. R. Stewart. Power Technologies, Inc., Schenectady, N.Y.

S. J. Dale. Oak Ridge National Laboratory, Oak Ridge, Tenn.

K. W. Klein. U.S. Department of Energy, Washington, D.C.

788 A Remote Sensor for Three Components of Translent Electric Flelds IEEE Trans. Industrial Electronics 35(3), pp. 426-33 (August 1988)

E. M. Thomson, P. J. Medelius, M. A. Uman. University of Florida, Gainesville, Fla.

789 Extrapolation of Measured Power System Response Data to High Altitude EMP Excitation

IEEE Trans. Electromagnetic Compatibility 30(3), pp. 386-92 (August 1988)

F. M. Tesche. LuTech, Inc., Dallas, Texas

P. R. Bames. Oak Ridge National Laboratory, Oak Ridge, Tenn.

790 Evaluation of New Metal-Insulator-Semlconductor Varlstor. Final Report ORNL/TM-10886 (August 1988)

F. A. Modine. Oak Ridge National Laboratory, Oak Ridge, Tenn.

791 The Development of Unique Power Converter

ORNL/Sub/81-09079/1 (May 1988)

L. R. Suelzle. Helionetics, Inc., Invine, Calif. 
792 Characteristlcs of Twelve-Phase Power Transmission

ORNL/Sub/85-00212/1 (April 1988)

J. R. Stewart. Power Technologies, Inc., Schenectady, N.Y.

793 Voltages Induced by Lightning on Electrlc Power Distrlbutlon Lines: Fleld Data and Analysls Results for the Perlod July 1984-86

ORNLSUb/84-89650/1 (March 1988)

M. A. Uman, E. M. Thomson, J. W. Stone, P. Medelius, M. Rubinstein. University of

Florida, Gainesville, Fla.

794 Harmonic Considerations for Electrical Distribution Feeders ORNL/Sub/81-95011/4 (March 1988)

R. C. Dugan. McGraw-Edison Power Systems, Canonsburg, Pa.

D. T. Rizy. Oak Ridge National Laboratory, Oak Ridge, Tenn.

795 Differences Between Lightning and Nuclear Electromagnetlc Pulse Interactions

IEEE Trans. Electromagnetic Compatibility 30(1), pp. 54-62 (February 1988)

E. F. Vance. SRI Intemational, Menlo Park, Calif.

M. A. Uman. University of Florida, Gainesville, Fla.

796 Role of Semiconducting Compounds in the Premature Aging of XLPE Cable Insulation

Conference Record of the 1988 IEEE International Symposium on Electrical Insulation, Boston, June 5-8, 1988, pp. 314-20 (1988)

M. S. Mashikian, J. H. Groeger. University of Connecticut, Storrs, Conn.

S. J. Dale. Oak Ridge National Laboratory, Oak Ridge, Tenn.

E. Ildstad. University of Trondheim, Nonway

797 Development of a New High-Altitude Electromagnetlc Pulse (HEMP) Environment and Resulting Overhead Line Responses

Electromagnetics 8(2-4), pp. 213-40 (1988)

F. M. Tesche. LuTech, Inc., Dallas, Texas

P. R. Bames. Oak Ridge National Laboratory, Oak Ridge, Tenn.

798 Early-Time Response of an Infinitely Long Wire Above a Finitely Conducting Earth to a Translent Plane Wave

Electromagnetics 8(2-4), pp. 159-70 (1988)

P. R. Barnes, R. A. Stevens. Oak Ridge National Laboratory, Oak Ridge, Tenn.

799 The Self-Energy of a Charge Near an Interface

Surface Science 194, pp. 275-311 (1988)

F. Sols. University of Illinois, Urbana, III.

R. H. Ritchie. Oak Ridge National Laboratory, Oak Ridge, Tenn.

800 Blological Effects of Spark-Decomposed $S F_{6}$

J. Electrochemic. Soc. 35(8), p. 381C (1988)

G. D. Grittin, M. G. Nolan, C. E. Eastenly, I. Sauers. Oak Ridge National Laboratory, Oak Ridge, Tenn.

801 By-Product Formation In Spark Breakdown of $\mathrm{SF}_{6} / \mathrm{O}_{2}$ Mixtures Plasma Chemistry and Plasma Processing 8(2), pp. 247-62 (1988)

I. Sauers. Oak Ridge National Laboratory, Oak Ridge, Tenn. 
802 Ion Chemistry in SF6 Corona

Proceedings of the Ninth Intemational Conference on Gas Discharges and Their Applications, Venice, Italy, Sept. 19-23, 1988, pp. 589-91 (1988)

I. Sauers. Oak Ridge National Laboratory, Oak Ridge, Tenn.

803 Production of $S_{2} F_{10}$ by $S_{6}$ Spark Discharges Proceedings of the Ninth International Conference on Gas Discharges and Their Applications, Venice, Haly, Sept. 19-23, 1988, pp. 592-94 (1988)

I. Sauers, P. C. Votaw, G. D. Griffin. Oak Ridge National Laboratory, Oak Ridge, Tenn.

804 On $S_{2} F_{10}$ Formation in Spark Breakdown of $S_{6}$

Conference Record of the 1988 IEEE International Symposium on Electrical Insulation, IEEE 88CH92594-0-El, pp. 112-15 (New York: IEEE, 1988)

I. Sauers, P. C. Votaw, G. D. Grittin, K. Kurka, C. E. Easterly. Oak Ridge National Laboratory, Oak Ridge, Tenn.

805 Horizontal Electric Fields from Lightning Return Strokes Joumal of Geophysical Research 93(D3), pp. 2429-41 (1988)

E. M. Thomson, P. Medelius, M. Rubinstein, M. A. Uman, J. Johnson, J. W. Stone. University of Florida, Gainesville, Fla.

806 Steep-Front Short-Duration Low Voltage Impulse Performance of Distrlbution Transformers

IEEE Trans. Power Delivery 2(4), pp. 1152-56 (October 1987)

B. W. McConnell. Oak Ridge National Laboratory, Oak Ridge, Tenn.

L. M. Burrage, E. F. Veverka. Cooper Industries, McGraw-Edison Power Systems,

Franksville, Wis.

807 Electrlc Power System Harmonics Design Gulde ORNL/Sub/81-95011/3 (September 1987)

R. C. Dugan, M. F. McGranaghan. McGraw-Edison Power Systems, Canonsburg, Pa.

D. T. Rizy, J. P. Stovall. Oak Ridge National Laboratory, Oak Ridge, Tenn.

808 The Effects of Corona on Current Surges Induced on Conducting LInes by EMP: A Comparison of Experiment Data with Results of Analytic Corona Models ORNL/Sub/85-27461/1 (September 1987)

J. P. Blanchard, F. M. Tesche. LuTech, Inc., Lafayette, Calif.

B. W. McConnell. Oak Ridge National Laboratory, Oak Ridge, Tenn.

809 Methodology for Control and Operation of Wind Arrays In UtIIty Systems ORNLSUb/81-7242/1 (April 1987)

T. D. Younkins. General Electric Co., Schenectady, N.Y.

810 Revlew and Evaluation of the Department of Energy's Research and Development Program for Solid Dlelectrlc and Synthetic Laminar Cable Insulations 1975-1986

ORNL/Sub/83-39099/1 (March 1987)

S. P. Walldorf. Consultant to Oak Ridge National Laboratory, Oak Ridge, Tenn.

811 Fault Current Limiter for Generator Bus Protection (27 kV, 600 A, 330 kA) ORNL/SUb/82-1743/1 (March 1987)

H. M. Pflanz. Phoenix Electric Corp., Boston, Mass. 


\section{Comparison of Costs and Benefits for DC and AC Transmission} ORNL-6204 (Febnuary 1987) J. P. Stovall, P. A. Gnadt. Oak Ridge National Laboratory, Oak Ridge, Tenn. J. P. Bowles, C. C. Diemond, R. L. Sullivan. Consultants to Oak Ridge National Laboratory, Oak Ridge, Tenn.

R. A. Eaton. U.S. Department of Energy, Washington, D.C.

S. V. Heyer. Philadelphia Electric Co., Philadelphia, Pa.

R. H. Lasseter, W. F. Long. University of Wisconsin, Madison, Wis.

M. A. Lebow. Consolidated Edison Company of New York, New York, N.Y.

J. C. Mclver, R. A. Walling. General Electric Co., Schenectady, N.Y.

E. C. Starr. Bonneville Power Administration, Portland, Ore.

\section{A Nominal Set of High-Altitude EMP Environments} ORNL/Sub/86-18417/1 (February 1987)

C. L. Longmire, R. M. Hamitton, J. M. Hahn. Mission Research Corp., Santa Barbara, Calif.

814 Assess the Impact of the Steep-Front, Short Duration Impulse on Electrlc Power System Insulation. Phase I-Final Report ORNL/Sub/85-28611/1 (February 1987)

L. M. Burrage, P. F. Hettwer, E. Howells, E. F. Veverka, I. D. Smith, J. K. Nelson, R. C. Dugan. McGraw-Edison Power Systems, Canonsburg, $\mathrm{Pa}$.

815 Impact of Adaptlve Protection on Power System Control Proceedings of the Ninth Power System Computation Conference, Cascais, Portugal, August 30-September 4, 1987, pp. 283-90 (Rochester, Great Britain: Staples Printers Rochester Ltd., 1987)

A. G. Phadke. Virginia Polytechnic Institute and State University, Blacksburg, Va.

J. S. Thorp. Cornell University, thaca, N.Y.

S. H. Horowitz. AEP Service Corporation, Columbus, Ohio

816 FLF Bloeffects: Use of Negative Data In a Structured Argument Proceedings of the Twenty-third Hanford Life Sciences Symposium, Richland, Washington, October 2-4, 1984, CONF-841041, pp. 543-52 (Richland, Wash.: Pacific Northwest Laboratory, 1987)

C. E. Easterly, T. E. Aldrich, M. D. Morris. Oak Ridge National Laboratory, Oak Ridge, Tenn.

817 Fast Pulse Response of Zinc Oxide Varlstors J. Appl. Phys. 61, p. 3093 (1987)

F. A. Modine, R. B. Wheeler. Oak Ridge National Laboratory, Oak Ridge, Tenn.

818 Investlgations of the Toxlcological Action of Spark-Decomposed SFG In Mammallan Cells

Gaseous Dielectrics V, ed. L. G. Christophorou and D. W. Bouldin, pp. 174-81 (New York: Pergamon Press, 1987)

G. D. Grittin, K. Kurka, I. Sauers, C. E. Easterly. Oak Ridge National Laboratory, Oak Ridge, Tenn.

$819 \mathrm{SOF}_{4}$ Production in Spark-Breakdown of $\mathrm{SF}_{6} / \mathrm{O}_{2}$ Mixtures Gaseous Dielectrics V, ed. L. G. Christophorou and D. W. Bouldin, pp. 205-12 (New York: Pergamon Press, 1987)

I. Sauers. Oak Ridge National Laboratory, Oak Ridge, Tenn. 
820 The Interaction Between an Electron and the Polarization Modes of a Metal-Insulator Interface

Solid State Communications 63, pp. 245-49 (1987)

F. Sols. University of llinois, Urbana, III.

R. H. Ritchie. Oak Ridge National Laboratory, Oak Ridge, Tenn.

821 Retardation of Annealing Embrittlement in Iron-Based Glasses by Microaddition of Cerium

Acta Metall. 35, pp. 989-1000 (1987)

D. M. Kroeger, G. S. Canright, C. G. McKamey, D. S. Easton, J. O. Scarbrough. Oak

Ridge National Laboratory, Oak Ridge, Tenn.

822 Transient and Harmonic Voltages Associated with Automated Capacitor Swltching on Distrlbution Systems

IEEE Trans. Power Systems 2(3), pp. 713-23 (New York: Institute of Electrical and

Electronic Engineers, 1987)

D. T. Rizy. Oak Ridge National Laboratory, Oak Ridge, Tenn.

E. W. Gunther, M. F. McGranaghan. McGraw-Edison Power Systems, Canonsburg, Pa. 


\section{SUPERCONDUCTING TECHNOLOGY PROGRAM FOR ELECTRIC ENERGY SYSTEMS}

823 Structural and Chemical Disorder Near the $\mathrm{Y}_{2} \mathrm{BaCuO} \mathrm{O}_{5} / \mathrm{YBa}_{2} \mathrm{Cu}_{3} \mathrm{O}_{7 . \delta}$ Intenface and Its Posslble Relation to the Flux-Pining Behavlor In MeltTextured $\mathrm{YBa}_{2} \mathrm{Cu}_{3} \mathrm{O}_{7 . \delta}$

Phys. Rev. B 47(9), pp. 5373-82 (March 1, 1993)

Z. L. Wang. University of Tennessee, Knoxville, Tenn.

A. Goyal, D. M. Kroeger. Oak Ridge National Laboratory, Oak Ridge, Tenn.

824 ORNL Superconducting Technology Program for Electric Energy Systems-Annual Report for FY 1992

ORNLHTSPC-4 (February 1993)

R. A. Hawsey. Oak Ridge National Laboratory, Oak Ridge, Tenn.

825 Irradiation-Enhanced PInning In $\mathrm{YBa}_{2} \mathrm{Cu}_{3} \mathrm{O}_{7-x}$ Crystals

JOM, pp. 60-64 (October 1992)

L. Civale, T. K. Worthington, L. Knusin-Elbaum, A. D. Marwick, F. Holtzberg. IBM Thomas

J. Watson Research Center, Yorktown Heights, N. Y.

J. R. Thompson. Oak Ridge National Laboratory, Oak Ridge, Tenn.

M. A. Kirk, R. Wheeler. Argonne National Laboratory, Argonne, III.

826 Protection of a Test Magnet Wound with Ag-BSCCO High-Temperature Superconductor ORNL/HTSPC-3 (October 1992)

L. Dresner. Oak Ridge National Laboratory, Oak Ridge, Tenn.

827 Superconducting Transport Properties of Epltaxlal YBa2 Cu3O Films: A Consistent Description Based on Thermally Activated Flux Motion

Phys. Rev. B 46(9), pp. 5576-80 (September 1, 1992)

S. Zhu, E. C. Jones. University of Tennessee, Knoxville, Tenn.

D. K. Christen, C. E. Klabunde, J. R. Thompson, R. Feenstra, D. H. Lowndes, D. P. Norton. Oak Ridge National Laboratory, Oak Ridge, Tenn.

828 Transport Critlcal Currents in Spray Pyrolyzed Fllms of $\mathrm{TIBa}_{2} \mathrm{Ca}_{2} \mathrm{Cu}_{3} \mathrm{O}_{2}$ on Polycrystalline Zirconla Substrates

Appl. Phys. Lett. 61(5), pp. 610-12 (August 3, 1992)

J. E. Tkaczyk, J. A. DeLuca, P. L. Karas, P. J. Bednarczyk, M. F. Garbauskas, R. H.

Arenot, K. W. Lay. General Electric Corporate Rzsearch and Development,

Schenectady, N. Y.

J. S. Moodera. Francis Bitter National Magnet Laboratory, Massachusetts Institute of Technology, Cambridge, Mass.

829 Powder Characteristics and Sintering Behavior of Ag-Doped

$\mathrm{YBa}_{2} \mathrm{Cu}_{3} \mathrm{O}_{7-x}$ Produced by Aerosol Decomposition

J. Mater. Res. 7(4), pp. 827-36 (April 1992)

T. L. Ward, T. T. Kodas. University of New Mexico, Albuquerque, N. Mex.

A. H. Carim. Pennsylvania State University, University Park, Pa.

D. M. Kroeger, H. Hsu. Oak Ridge National Laboratory, Oak Ridge, Tenn. 
830 Microstructure Within Domalns of Melt-Processed $\mathrm{YB1}_{2} \mathrm{Cu}_{3} \mathrm{O}_{7-x}$ Supereonductors

Phys. Rev. B 45, pp. 5622-27 (March 1992)

K. B. Alexander, A. Goyal, D. M. Kroeger. Oak Ridge National Laboratory, Oak Ridge, Tenn.

V. Selvamanickam, K. Salama. University of Houston, Houston, Texas

831 Proceedings of the HTS Wire Development Workshop, February 1920, 1992. DOE/Offlce of UtIlity Technologies Summary of Projects, Superconducting Technology Program for Electric Energy Systems CONF-920286 (Oak Ridge, Tenn.: Oak Ridge National Laboratory, February 1992) R. A. Hawsey, ed. Oak Ridge National Laboratory, Oak Ridge, Tenn.

832 A Comprehenslve Review of the XRD Data of the Primary and Secondary Phases Present in the BSCCO Superconductor System (Part 11: Ca-Sr-Pb Ox(des)

ORNLTM-11949 (February 1992)

B. J. Reardon, C. R. Hubbard. Oak Ridge National Laboratory, Oak Ridge, Tenn.

833 A Comprehensive Revlew of the XRD Data of the Primary and Secondary Phases Present In the BSCCO Superconductor System (Part I: Ca-Sr-Cu Oxides)

ORNL/TM-11948 (January 1992)

B. J. Reardon, C. R. Hubbard. Oak Ridge National Laboratory, Oak Ridge, Tenn.

834 Phase Development in the $\mathrm{Bl}_{2} \mathrm{Sr}_{2} \mathrm{CaCu}_{2} \mathrm{O}_{y}$ System: Effects of Oxygen Pressure

Physica C 202, pp. 134-40 (1992)

F. A. List, H. Hsu, O. B. Cavin, W. D. Porter, C. R. Hubbard, D. M. Kroeger. Oak Ridge

National Laboratory, Oak Ridge, Tenn.

835 Interface Microstructures in Melt-Textured $\mathrm{YBa}_{2} \mathrm{Cu}_{3} \mathrm{O}_{7-\delta}$ on $\mathrm{Ag}-\mathrm{Pd}$ and Flux PInning Centers Introduced by $\mathrm{Y}_{2} \mathrm{BaCuO}_{5}$ Particles

Proceedings 50th Annual Meeting, Electron Microscopy Society of America, Boston,

August 16-21, 1992, pp. 72-73 (Electron Microscopy Society of America, 1992)

Z. L. Wang. University of Tennessee, Knoxville, Tenn.

A. Goyal, D. M. Kroeger. Oak Ridge National Laboratory, Oak Ridge, Tenn.

$836 T_{C-\delta}$ Relations In YBa2C $u_{3} \mathrm{O}_{7-\delta}$ Thin Films: Effects of Oxygen Pressure During Growth

Procoodings, Spring Meeting, Materials Research Society, 275, pp. 101-106

(Pittsburgh: Materials Research Society, 1992)

R. Feenstra, D. P. Norton, J. D. Budai, D. K. Christen, D. H. Lowndes. Oak Ridge National Laboratory, Oak Ridge, Tenn.

V. C. Matijasevic, C.-B. Eom, T. H. Geballe. Stanford University, Stanford, Calif.

E. S. Hellman, E. H. Hartiord. AT\&T Bell Labs, Murray Hill, N. J.

837 Thermodynamics of the Y-Ba-Cu-C.O-H System: Application to the Organometallic Chemical Vapor Deposition of the $\mathrm{YBa}_{2} \mathrm{Cu}_{3} \mathrm{O}_{7-x}$ Phase J. Am. Ceram. Soc. 75(10), pp. 2679-86 (1992)

C. Vahlas. Laboratoire Marcel Mathieu, France

T. M. Besmann. Oak Ridge National Laboratory, Oak Ridge, Tenn. 
838 Enhanced Current Denslty $J_{c}$ In Single Crystal $\mathrm{Bl}_{2} \mathrm{Sr}_{2} \mathrm{Ca}_{1} \mathrm{Cu}_{2} \mathrm{O}_{8}$ vla Linear Defects from Heavy Ion Irradiation

Bull. Am. Phys. Soc. 37, p. 172 (1992)

J. R. Thompson, H. R. Kerchner, D. K. Christen, B. C. Sales, B. C. Chakoumakos. Oak

Ridge National Laboratory, Oak Ridge, Tenn.

Y. R. Sun, J. O. Thomson. University of Tennessee, Knoxville, Tenn.

L. Civale, A. D. Marwick. IBM Thomas J. Watson Research Center, Yorktown Heights,

N. Y.

839 Flex Creep Studies in Grain-Allgned $\mathrm{YBa}_{2} \mathrm{Cu}_{3} \mathrm{O}_{7-\delta}$ vs Oxygen Deficlency Delta

Bull. Am. Phys. Soc. 37, p. 118 (1992)

J. R. Thompson, D. K. Christen. Oak Ridge National Laboratory, Oak Ridge, Tenn.

J. G. Ossandon, Y. R. Sun. University of Tennessee, Knoxville, Tenn.

840 A Review of the XRD Data of the Phases Present in the CaO-SrO-PbO System

Powder Diffr. 7(2), pp. 96-98 (1992)

B. J. Peardon. Alfred University, Alfred, N. Y.

C. R. Hubbard. Oak Ridge National Laboratory, Oak Ridge, Tenn.

841 Magnetization Studies of Irradlation Modifled Single Crystal $\mathrm{Y}_{1} \mathrm{Ba}_{2} \mathrm{Cu}_{3} \mathrm{O}_{7}$ Superconductors: Flux Creep and Anneallng Effects Physics and Materials Science of High Temperature Superconductors, II, pp. 573-93 (Dordrecht: Kluwer, 1992)

J. R. Thompson, D. K. Christen, H. R. Kerchner. Oak Ridge National Laboratory, Oak Ridge, Tenn.

Y. R. Sun. University of Tennessee, Knoxville, Tenn.

A. P. Malozemoff, L. Civale, A. D. Marwick, T. K. Worthington, L. Krusin-Elbaum, F. Holtzberg. IBM Thomas J. Watson Research Center, Yorktown Heights, N. Y.

842 Excess Heat Production In Composite Superconductors During Current Redistribution

ORNLTM-11827 (May 1991)

L. Dresner. Oak Ridge National Laboratory, Oak Ridge, Tenn.

843 The Structure and Chemistry of Grain Boundaries In Ceramic Superconductors

Proceedings of the American Ceramic Society Second International Ceramic Science and Technology Congress, Orlando, Florida, November 12-15, 1990, 19, pp. 365-72 (Westerville, Ohio: American Ceramic Society, 1991)

K. B. Alexander, R. K. Williams, D. M. Kroeger, J. Brynestad. Oak Ridge National Laboratory, Oak Ridge, Tenn.

844 Reduced Flux Motion via Creep Anneallng In High-Jc SIngle-Crystal $\mathrm{Y}_{1} \mathrm{Ba}_{2} \mathrm{Cu}_{3} \mathrm{O}_{7}$

Appl. Phys. Lett. 59, pp. 2612-14 (1991)

J.R. Thompson, D. K. Christen, H. R. Kerchner. Oak Ridge National Laboratory, Oak Ridge, Tenn.

Y. R. Sun, J. G. Ossandon. University of Tennessee, Knoxville, Tenn.

A. P. Malozemoff, A. Marwick, F. Holtzberg. IBM Thomas J. Watson Research Center, Yorktown Heights, N. Y. 
845 Long-Term, Nonlogarlthmic Magnetic Relaxation In Singlo-Crystal $\mathrm{YBa}_{2} \mathrm{Cu}_{3} \mathrm{O}_{7}$ Superconductor

Phys. Rev. B 44, pp. 458-61 (1991)

J. R. Thompson. Oak Ridge National Laboratory, Oak Ridge, Tenn.

Y. R. Sun. University of Tennessee, Knoxville, Tenn.

F. H. Holtzberg. IBM Thomas J. Watson Research Center, Yorktown Heights, N. Y.

846 Critical Current Enhancement by the Extended Vortex Confinement In YBaCuO Single Crystals

Bull. Am. Phys. Soc. 36, p. 669 (1991)

L. Civale, T. K. Worthington, L. Krusin-Elbaum, A. P. Malozemoff, F. Holtzberg, C. A.

Feild. IBM Thomas J. Watson Research Center, Yorktown Heights, N. Y.

J. R. Thompson. Oak Ridge National Laboratory, Oak Ridge, Tenn.

M. A. Kirk. Argonne National Laboratory, Argonne, III.

847 Vortex Confinement by Columnar Defects In $\mathrm{YBa}_{2} \mathrm{Cu}_{3} \mathrm{O}_{7}$ Crystals: Enhanced Pinning at High Fields and Temperatures

Phys. Rev. Lett. 67, pp. 648-51 (1991)

L. Civale, A. D. Marwick, T. K. Worthington, L. Krusin-Elbaum, F. H. Holtzberg. IBM

Thomas J. Watson Research Center, Yorktown Heights, N. Y.

M. A. Kirk. Argonne National Laboratory, Argonne, III.

J. R. Thompson, Y. Sun. Oak Ridge National Laboratory, Oak Ridge, Tenn.

J. R. Clem. lowa State University, Ames, lowa

848 Critical Currents In Proton Irradlated YBa2 $\mathrm{Cu}_{3} \mathrm{O}_{7-\delta}$ Crystals

Progress in High Temperature Superconductivity 31, pp. 25-43 (Singapore: World

Scientific Publishing Co., 1991)

L. Civale, M. W. McElfresh, A. D. Marwick, T. K. Worthington, A. P. Malozemoff, F.

Holtzberg, C. Feild. IBM Thomas J. Watson Research Center, Yorktown Heights, N. Y.

J. R. Thompson, D. K. Christen. Oak Ridge National Laboratory, Oak Ridge, Tenn.

M. A. Kirk. Argonne National Laboratory, Argonne, III.

849 The Hardness and Young's Modulus of Bulk $\mathrm{KBa}_{2} \mathrm{Cu}_{3} \mathrm{O}_{7-x}$ (1:2:3) and $\mathrm{YBa}_{2} \mathrm{Cu}_{4} \mathrm{O}_{8}$ (1:2:4) as Determined by Uitra Low Load Indentation

J. Mater. Res. 6, pp. 2519-22 (1991)

B. N. Lucas. University of Tennessee, Knoxville, Tenn.

W. C. Oliver, R. K. Williams, J. Brynestad. Oak Ridge National Laboratory, Oak Ridge, Tenn.

M. E. O'Hem. Nano Instruments, Inc., Knoxville, Tenn.

850 An/sotroplc Thermal Expansion of the 1:2:4 Yttrium Barlum Copper Oxide Superconductors

Physica C 172, pp. 486-90 (1991)

K. Doverspike, C. R. Hubbard, R. K. Williams, K. B. Alexander, J. Brynestad, D. M.

Kroeger. Oak Ridge National Laboratory, Oak Ridge, Tenn.

851 Some Observations of the Effects of High Pressures and Temperatures on the Stability of $\mathrm{YB}_{2} \mathrm{Cu}_{3} \mathrm{O}_{7-x}$

Journal of Applied Physics 67(11), pp. 6934-39 (1990)

R. K. Williams, K. B. Alexander, J. Brynestad, T. J. Henson, D. M. Kroeger, T. B.

Lindemer, G. C. Marsh, J. O. Scarbrough. Oak Ridge National Laboratory, Oak Ridge, Tenn. 
852 Superconductlvity, Inter- and Intra-graln Critlcal Current Densities of $\mathrm{TI}_{2} \mathrm{Ca}_{2} \mathrm{Ba}_{2} \mathrm{Cu}_{3} \mathrm{O}_{10+X}$ and $\mathrm{Tl}_{2} \mathrm{CaBa}_{2} \mathrm{Cu}_{2} \mathrm{O}_{8}+x$ Materlals

Phys. Rev. B 39, pp. $6652-59$ (April 1989)

J. R. Thompson, J. Brynestad, D. M. Kroeger, S. T. Sekula, D. K. Christen, E. D. Specht.

Oak Ridge National Laboratory, Oak Ridge, Tenn.

Y. C. Kin. University of Tennessee, Knoxville, Tenn.

853 Grain Boundarles and Critical Current Density In High Temperature Oxide Superconductors

Joumal of Metals 41, pp. 14-17 (1989)

D. M. Kroeger. Oak Ridge National Laboratory, Oak Ridge, Tenn.

854 Effect of Oxygen Pressure on the Orthorhomblc to Tetragonal Transition In the HIgh Temperature Superconductor $\mathrm{YBa}_{2} \mathrm{Cu}_{3} \mathrm{O}_{7}$

Phys. Rev. B 37, pp. 7426-34 (1988)

E. D. Specht, C. J. Sparks, A. G. Dhere, J. Brynestad, O. B. Cavin, D. M. Kroeger. Oak

Ridge National Laboratory, Oak Ridge, Tenn.

H. A. Oye. U.S. Air Force Academy, Colorado Springs, Colo.

855 Effects of Small Devlatlons from Stolchlometry on Graln Boundary Compositions in $\mathrm{YBa}_{2} \mathrm{Cu}_{3} \mathrm{O}_{7}$

Interfacial Structure, Properties and Design. Materials Research Society Symposium

Proceodings 122, ed. M. H. Yoo, W. A. T. Clark and C. L. Briant, pp. 521-26 (Pittsburgh:

Materials Research Society, 1988)

D. M. Kroeger, J. Brynestad, R. K. Williams, R. A. Padgett, J. O. Scarbrough. Oak Ridge

National Laboratory, Oak Ridge, Tenn.

856 Changes in Fracture Surface Composition and Morphology wlin Time in Vacuum in $\mathrm{YBa}_{2} \mathrm{Cu}_{3} \mathrm{O}_{7}$

Appl. Phys. Lett. 52, pp. 1266-67 (1988)

D. M. Kroeger, J. Brynestad, R. A. Padgett. Oak Ridge National Laboratory, Oak Ridge, Tenn.

857 Graln Boundary Compositions In $\mathrm{YBa}_{2} \mathrm{Cu}_{3} \mathrm{O}_{7}$ from Auger Spectroscopy of Fracture Surfaces

J. Appl. Phys. 64, pp. $331-35$ (1988)

D. M. Kroeger, J. Brynestad, R. K. Williams, R. A. Padgett. Oak Ridge National Laboratory, Oak Ridge, Tenn.

A. Choudhury. University of Califomia, Davis, Calif.

W. A. Coghlan. Arizona State University, Tempe, Ariz.

858 Electron Microscopy of High-Temperature Oxide Superconductors Proceedings of the 45th Annual Meeting of the Electron Microscopy Society of America, Baltimore, August 2-7, 1987, ed. G. W. Bailey, pp. 52-53 (San Francisco: San Francisco Press, Inc., 1987)

J. Bentley, A. T. Fischer, C. P. Haltom, J. Brynestad, R. J. Lauf, R. K. Williams, D. M. Kroeger. Oak Ridge National Laboratory, Oak Ridge, Tenn. 


\section{THERMAL ENERGY STORAGE}

859 Thermal Energy Storage Technical Progress Report April 1992-March 1993

ORNLTM-12384 (May 1993)

M. Olszewski. Oak Ridge National Laboratory, Oak Ridge, Tenn.

860 Thermal Energy Storage Technical Progress Report Aprll 1990-March 1991

ORNLTM-12081 (March 1992)

J. J. Tomlinson. Oak Ridge National Laboratory, Oak Ridge, Tenn.

861 Development of a Complex Compound ChIII Storage System

ORNL/Sub/85-57432/1 (August 1991)

U. Rockenteller, L. Kirol. Rocky Research, Boubler City, Nev.

862 Turbo Refrigerating Company Ice Storage Test Report

ORNL/TM-11657 (June 1991)

T. K. Stovall. Oak Ridge National Laboratory, Oak Ridge, Tern.

863 Wallboard with Latent Heat Storage for Passive Solar Applications ORNLTM-11541 (May 1991)

R. J. Ked. Oak Ridge National Laboratory, Oak Ridge, Tenn.

864 Thermal Energy Storage Technlcal Progress Report Aprll 1989-March 1990

ORNLTM-11819 (March 1991)

J. J. Tomlinson. Oak Ridge National Laboratory, Oak Ridge, Tenn.

865 Development of Compos/te Latent/Senslble Heat Storage Media ORNL/Sub/86-95011/1 (December 1990)

R. Petri, E. T. Ong, A. Kardas. Institute of Gas Technology, Chicago, III.

866 Thermal Energy Storage

Mechanical Engineering 112(9) (September 1990)

J. J. Tomlinson. Oak Ridge National Laboratory, Oak Ridge, Tenn.

L. D. Kannberg. Battelle Pacific Northwest Laboratories, Richland, Wash.

867 Bolling/Evaporatlve Heat Transfer from Spheres In Packed-Bed Thermal Energy Storage Units. Final Report

ORNL/Sub/86-7685/2 (May 1990)

R. V. Arimilli, C. A. Moy. University of Tennessee, Knoxville, Tenn.

868 Thermal Energy Storage Technlcal Progress Report Aprll 1987-March 1988

ORNLTM-11233 (September 1989)

J. J. Tomlinson, R. J. Kedl. Oak Ridge National Laboratory, Oak Ridge, Tenn.

869 Development of Ice Self-Release Mechanisms. Final Report ORNL/SUb/87-SB064/1 (September 1989)

W. E. Stewart, Jr. University of Missouri-Columbia/Kansas City, Truman Campus, Independence, Mo. 
870 Complex.Compound Low.Temperature TES System U.S. Department of Energy Thermal Energy Storage Research Activities Review 1989 Proceedings, CONF-890351, pp. 217-36 (1989)

U. Rockenfeller. Rocky Research Corp., Boulder City, Nev.

\section{Prellminary TES Design Optimization Study for a Simple Perlodic Brick Plant}

U.S. Department of Energy Thermal Energy Storage Research Activities Review 1989 Proceedings, CONF-890351, pp. 197-207 (1989)

J. B. Drake, M. Otszewski, M. J. Taylor, J. J. Tomlinson. Oak Ridge National Laboratory, Oak Ridge, Tenn.

A. D. Solomon. Consultant to Oak Ridge National Laboratory, Oak Ridge, Tenn.

\section{Thermal Energy Storage with Llquld-Llquid Systems}

U.S. Department of Energy Thermal Energy Storage Research Activities Review 1989 Proceedings, CONF-890351, pp. 146-70 (1989)

E. A. Santana, L. I. Stiel. New York Polytechnic Institute, Brooklyn, N.Y.

873 Self-Releasing Submerged Ice Maker

U.S. Department of Energy Thermal Energy Storage Research Activities Review 1989 Proceedings, CONF-890351, pp. 128-45 (1989)

W. E. Stewart, Jr.; M. E. Greer, L. A. Stickler. University of Missouri-Columbia/Kansas City, Truman Campus, Independence, Mo.

874 Computer and Graphics Modeling of Heat Transfer and Phase Change In a Wall with Randomly Imblbed PCM

U.S. Department of Energy Thermal Energy Storage Research Activities Review 1989 Procerdings, CONF-890351, pp. 124-27 (1989)

A. D. Solomon. Consultant to Oak Ridge National Laboratory, Oak Ridge, Tenn.

875 Development of PCM Wallboard for Heating and Coolling of Residentlal Bulldings

U.S. Department of Energy Thermal Energy Storage Research Activities Review 1989

Proceedings, CONF-890351, pp. 97-123 (1989)

I. Salyer, A. Sircar. University of Dayton Research Institute, Dayton, Ohio

876 Development of a Direct Contact lce Storage System

U.S. Department of Energy Thermal Energy Storage Research Activities Review 1989

Proceedings, CONF-890351, pp. 93-96 (1989)

C. Poirier. CBI Industries, Plainfield, III.

877 Effects of Dopants on Crystal Structure and Thermal Properties of Pentaglycerine

U.S. Department of Energy Thermal Energy Storage Research Activities Review 1989 Proceedings, CONF-890351, pp. 58-75 (1989)

D. Chandra, W. Ding. University of Nevada, Reno, Nev.

878 Evaporative Heat Transfer in Beds of Sensible Heat Pellets U.S. Department of Energy Thermal Energy Storage Research Activities Review 1989 Proceedings, CONF-890351, pp. 26-57 (1989)

R. V. Arimilli, C. A. Moy. University of Tennessee, Knoxville, Tenn.

879 Overvlew of the Dlurnal and Industrlal Thermal Energy Storage Programs U.S. Department of Energy Thermal Energy Storage Research Activities Review 1989 Proceedings, CONF-890351, pp. 19-25 (1989)

J. J. Tomlinson. Oak Ridge National Laboratory, Oak Ridge, Tenn. 
880 Actlvitles in Support of the Wax-Impregnated Wallboard Concept U.S. Department of Energy Thermal Energy Storage Research Activities Review 1989 Proceedings, CONF-890351, pp. 75-91 (1989)

R. J. Kedl, T. K. Stovall. Oak Ridge National Laboratory, Oak Ridge, Tenn.

881 Hypereutectlc Heat Storage Alloy Final Report: Sillcon Shell Integrity in Molten Al-SI Eutectlc ORNLTM-10380 (June 1988)

M. R. Bennett, J. Braunstein. Oak Ridge National Laboratory, Oak Ridge, Tenn.

882 Thermal Energy Storage Technical Progress Report Aprll 1986-March 1987

ORNUTM-10715 (February 1988)

J. J. Tomlinson, M. J. Taybr. Oak Ridge National Laboratory, Oak Ridge, Tenn.

883 First and Second Law Studles on Packed Bed Energy Storage Systems UtIlizing Phase-Change Materlals Proceedings ASME Winter Annual Meeting HTD-97, pp. 9-18 (New York: American Society of Mechanical Engineers, 1988)

G. A. Adebiyi. Mississippi State University, Mississippi State, Miss.

884 Mechanical Energy Storage

Mech. Eng. 110, pp. 50-58 (1988)

M. Olszewski. Oak Ridge National Laboratory, Oak Ridge, Tenn.

N. Beachley. University of Wisconsin, Madison, Wis.

D. B. Eisenhaure. Satcon Technology Corp., Cambridge, Mass.

J. A. Kirk. University of Maryland, College Park, Md.

885 Heats of Mixing for Thermal Energy Storage Systems, Phase I: Selection of Sultable Liquid-Llquid Mixtures

ORNL/Sub/86-27470/1 (July 1987)

L. I. Stiel. New York Polytechnic Institute, Brooklyn, N.Y.

886 Thermal Energy Storage Technical Progress Report Aprll 1985-March 1986

ORNL/TM-10247 (February 1987)

J. F. Martin. Oak Ridge National Laboratory, Oak Ridge, Tenn. 


\title{
BIOFUELS FEEDSTOCK DEVELOPMENT
}

\author{
887 Blofuels Feedstock Development Program Annual Progress Report for \\ 1991 \\ ORNL-6742 (July 1992) \\ L. L. Wright, J. H. Cushman, A. R. Etrenshath, S. B. McLaughlin, iN. A. McNabb, J. W. \\ Ranney, G. A. Tuskan, A. F. Tumollow. Oak Ridge National Laboratory, Oak Ridge, Tern.
}

888 Environmental Em/sslons and Socloeconomic considerations in the Production, Storage, and Transportation of Blomass Energy Feedstocks ORNLTM-12030 (July 1992)

R. D. Perlack, J. W. Ranney, L. L. Wright. Oak Ridge National Laboratory, Oak Ridge, Tenn.

889 Development of Blomass Energy Crops

Proceedings of the Annual Automotive Technology Development Contractors'

Coordination Meeting 1991 P-256, pp. 687-89 (Warrendale, Pa.: Society of

Automotive Engineers, June 1992)

L. L Wright, J. H. Cushman. Oak Ridge National Laboratory, Oak Ridge, Tenn.

890 Genetic Improvement of Hybrid Poplars for Short Rotation Blomass Production

Proceedings of the Annual Automotive Technology Development Contractors' Coordination Meeting 1991 P-256, pp. 691-92 (Warrendale, Pa.: Society of Automotive Engineers, June 1992)

R. F. Stettler, T. M. Hinckley, H. D. Bradshaw, Jr. University of Washington, Seattle, Wash.

P. E. Heilman. Washington State University, Seattle, Wash.

891 Selection and Breeding of Pest-Resistant Clones of Populus for Blomass Energy Production in the North Central Region

Procoedings of the Annual Automotive Technology Development Contractors' Coordination Meeting 1991 P-256, pp. 693-702 (Warrendale, Pa.: Society of Automotive Engineers, June 1992)

R. B. Hall, E. R. Hart, H. S. McNabb, Jr., B. G. McMahon, R. D. Hanna. lowa State University, Ames, lowa

892 Blofuels Feedstock Production Research Directions for 1992 Proceedings of the Annual Automotive Technology Development Contractors' Coordination Meeting 1991 P.256, pp. 703-707 (Warrendale, Pa.: Society of Automotive Engineers, June 1992)

J. H. Cushman. Oak Ridge National Laboratory, Oak Ridge, Tenn.

893 Selection of Herbaceous Energy Crops for Production in Double Cropplng Systems

Proceedings of the Annual Automotive Technology Development Contractors' Coordination Meeting 1991 P-256, pp. 709-12 (Warrendale, Pa.: Society of Automotive Engineers, June 1992)

D. R. Buxton, I. C. Anderson. lowa State University, Ames, lowa 
894 Short Rotation Woody Crop Trials for Energy Production In North Central U.S. Proceedings of the Annual Automotive Technology Development Contractors' Coordination Meeting 1991 P-256, pp. 715-16 (Warrendale, Pa.: Society of Automotive Engineers, June 1992)

E. A. Hansen. USDA Forest Service, North Central Experiment Station, Rhinelander, Wis.

895 Environmental Conslderations In Blomass Resource Management for a Greenhouse-Constralned Soclety Technologies for a Greenhouse-Constrained Societ;, ed. M. A. Kuliasha, A. Zucker, and K. J. Ballew, pp. 519-45 (Chelsea, Mich.: Lewis Publishers, Inc., 1992) J. W. Ranney. Oak Ridge National Laboratory, Oak Ridge, Tenn.

896 Photosynthesis, Water Relations, and Growth of Two Hybrid Populus Genotypes During a Severe Drought

Can. J. For. Res. 22(8), pp. 1094-1106 (1992)

D. I. Dickmann, Z. Liu, P. V. Nguyen, K. S. Pregitzer. Michigan State University, East Lansing, Mich.

897 Nursery Establishment, Phenology and Growth of SIlver Maple Related to Provenance

Biomass and Bioenergy 3, pp. 1-7 (1992)

W. C. Ashby, D. F. Bresnan, P. L. Roth, J. E. Preece, C. A. Huetteman. Southern Illinois University, Champagne, III.

898 Genetic Varlation and Productivity of Populus trichocarpa T. \& G. and Its Hybrids: $V$. The influence of Ramet Position on Three-Year Growth Varlables

Can. J. For. Res. 23, pp. 349-57 (1992)

J. D. Dunlap, R. F. Stettler. University of Washington, Seattle, Wash.

P. E. Heilman. Washington State University, Puyallup, Wash.

899 Environmental and Genetlc Influences on Short-Rotation Blomass Production of Black Locust (RobInla pseudoacacla L.) in the Georgla Pledmont

For. Ecol. Manag. 55, pp. 315-31 (1992)

B. C. Bongarten, D. A. Huber, D. K. Apsley. University of Georgia, Athens, Ga.

900 Genetic and Physlological Investigatlons of Seedling Development and Steckllng Growth for American Sycamore (Platanus occidentalls L.) Doctoral dissertation, Mississippi State University, 1992

Z. Tang. Mississippi State University, Mississippi State, Miss.

901 Blomass Energy Development In Yunnan Province, China. Preliminary Evaluation

ORNLTM-11791 (June 1991)

R. D. Perlack, J. W. Ranney, M. Russell. Oak Ridge National Laboratory, Oak Ridge, Tenn.

902 Development of a Farm-Firm Modelling System for Evaluation of Herbaceous Energy Crops ORNL/Sub/88-SC616/2 (March 1991)

B. C. English, R. R. Alexander, K. H. Loewen, S. A. Coady, G. V. Cole, W. R. Goodman. Department of Agricultural Economics and Rural Sociology, University of Tennessee, Knoxville, Tenn. 
903 Chilling and Bud Break In Silver Maple

J. Environ. Hort. 9, pp. 1-4 (1991)

W. C. Ashby, D. F. Bresnan, C. A. Huetteman, J. E. Preece, P. I. Roth. Southem Illinois University, Champagne, III.

904 Registration of 'Rebel' Rapeseed

Crop Sci. 31, pp. 485-86 (1991)D. L. Auld, K. A. Mahler, D. C. Thrill, L. A. Erickson, P. L.

Raymer, D. C. Bridges, J. L. Butler. University of Idaho, Moscow, Idaho

905 Registration of Two Rapeseed Germplasm Populations Crop Sci. 31, pp. 493-94 (1991)

D. L. Auld, K. A. Mahler, D. C. Thrill, D. A. Erickson, P. L. Raymer, J. L. Sernyk. University of Idaho, Moscow, Idaho

906 Blomass Energy: Exploring the Risks of Commercialization in the United States of Amerlca

Bioresource Technology 35, pp. 1-13 (1991)

R. A. Cantor, C. G. Rizy. Oak Ridge National Laboratory, Oak Ridge, Tenn.

907 Land Application of Sludge to Forest and Herbaceous Energy Crops

Ames Forester, pp. 24-30 (1991)

J. P. Colletti, C. Mize, D. Schultz, L. Rule, A. Skadberg, R. Hail, P. Wray. lowa State

University, Ames, lowa

908 Agroforestry Systems for the Midwest

Ames Forester, pp. 10-13 (1991)

J. P. Colletti, L. Rule, A. Skadberg, D. Schultz, C. Mize, R. Hall, P. Wray. lowa State

University, Ames, lowa

909 Selecting Herbacious Energy Crops for the Southeast and Midwest/Lake

States

Energy from Biomass and Wastes XIV, ed. D. L. Klass, pp. 465-480 (Chicago, III.: Institute of Gas Technology, 1991)

J. H. Cushman, A. F. Turhollow. Oak Ridge National Laboratory, Oak Ridge, Tenn.

910 Leaves as Regulators of Stress Response

Response of Plants to Multiple Stresses, ed. H. A. Mooney et al., pp. 3-34 (San Diego,

Calif.: Academic Press, Inc., 1991)

R. E. Dickson, J. G. Isebrands. USDA Forest Service, North Central Experiment Station, Rhinelander, Wis.

911 The Short Rotation Woody Crops Program Data Base

Bioresource Technology 36, pp. 241-246 (1991)

A. R. Ehrenshaft, L. L. Wright. Oak Ridge National Laboratory, Oak Ridge, Tenn.

912 Blomass Crop Production on Representative Southeastern U.S. Farms:

Farm Profitability, Erosion Control and the 1985 Food Security Act

Bioresource Technology 36, pp. 207-214 (1991)

W. R. Goodman, S. A. Coady, B. C. English. University of Tennessee, Knoxville, Tenn.

913 Dormancy Induction Treatment Influence on Western Hemlock Seedlings. I. Seedling Development and Stock Quality Assessment

Can. J. For. Sci. 21, pp. 164-174 (1991)

S. C. Grossnickle, J. T. Amott, J. E. Major, T. J. Tschaplinski. Oak Ridge National

Laboratory, Oak Ridge, Tenn. 
914 Actlvity of the Fenusa dohrnil (Hymenoptera: tenthredenidae) on Alnus In the Northcentral Unlted States

Environ. Entomol. 20, pp. 534-539 (1991)

E. R. Hart, D. G. Petty, R. B. Hall, D. A. Herms, R. D. Hanna, J. N. Kean. lowa State

University, Ames, lowa

915 Dispersal of Fenusa dohrnil (Hymenoptera: tenthredinidae) from an Alnus Short-Rotation Forest Plantation

Great Lakes Entomologist 24, pp. 63-68 (1991)

E. R. Hart, R. B. Hall, R. D. Hanna, lowa State University, Ames, lowa

916 Effects of Nitrate on In vitro Nitrate Reductase Actlvity of Seedilngs from Three Open-Pollinated Familles of Robinla pseudoacacla

Tree Physiology 8, pp. 381-389 (1991)

K. H. Johnson, B. C. Bongarten, L. R. Boring. University of Georgia, Athens, Ga.

917 Fuel Ethanol from Cellulosic Biomass

Science 251, pp. 1318-1323 (1991)

L. R. Lynd. Thayer School of Engineering, Dartmouth College, Hanover, N. H.

J. H. Cushman. Oak Ridge National Laboratory, Oak Ridge, Tenn.

R. J. Nichois. Ford Motor Company, Dearborn, Mich.

C. E. Wyman. National Energy Research Laboratory, Golden, Colo.

918 Blological Markers In Animals and Plants to Establish Exposure to, and Effects of, Atmospheric Toxicants

Ecological Exposure and Effects of Airborne Toxic Chemicals: An Overview, ed. T. J.

Moser, J. R. Baker, and D. T. Tingey, pp. 107-127 (Convallis, Ore.: U.S. Environmental

Protection Agency, 1991)

J. F. McCarthy, T. J. Tschaplinski. Oak Ridge National Laboratory, Oak Ridge, Tenn.

919 Disease and Insect Resistance: A Key to Successful Short Rotation Woody Crops Systems

Ames Forester 78, pp. 31-33 (1991)

H. S. McNabb, Jr., E. R. Hart, R. B. Hall. lowa State University, Ames, lowa

920 A Fleld Trial of Transgenlc Hybrld Poplar Trees: Establishment and Growth Through The Second Season

Biological Monitoring of Genetically Engineered Plants and Microbes, ed. D. R.

MacKenzie and S. C. Henry, pp. 155-159 (Bethesda, Md.: Agricultural Research Institute, 1991)

H. S. McNabb, Jr., N. B. Klopfenstein, R. D. Hanna, R. B. Hall, E. R. Hart, S. A. Heuchelin,

R. W. Thornbur. lowa State University, Ames, lowa

921 A Flve-Year Study of Herbaceous Energy Crops

Proc., Energy from Biomass and Wastes XIV, ed. D. L. Klass, pp. 447-464 (Chicago, III.: Institute of Gas Technology, 1991)

D. J. Parrish, D. D. Wolf, W. L. Daniels, J. S. Cundift, D. H. Vaughan. Virginia PolyTechnic Institute and State University, Blacksburg, Va.

922 Micro- and Custing Propagation of Sllver Maple. I. Results with Aduli and Juvenlle Propagules

J. Amer. Soc. Hort. Sci. 116, pp. 142-148 (1991)

J. E. Preece, C. A. Huetteman, W. C. Ashby, P. L. Roth. Southern Illinois University,

Champagne, III. 


\section{Energy from Blomass}

The Energy Sourcebook: a Guide to Technology, Resources and Policy, pp. 299-311

(New York: American Institute of Physics, 1991)

J. W. Ranney, J. H. Cushman. Oak Ridge National Laboratory, Oak Ridge, Tenn.

924 Carbon Storage and Recycling In Short-Rotation Energy Crops Proc., Bioenergy and the Greenhouse Effect, ed. C. P. Mitchell, pp. 39-60 (Stockholm, Sweden: International Energy Agency and National Energy Administration of Sweden, 1991)

J. W. Ranney, L. L. Wright, C. P. Mitchell. Oak Ridge National Laboratory, Oak Ridge, Tenn.

925 Woody Blomass Production Costs in the United Siates: An Economic Summary of Commerclal Populus Plantation Systems

Proc., Energy from Biomass and Wastes XIV, ed. D. L. Klass, pp. 359-369 (Chicago, III.: Institute of Gas Technology, 1991)

C. H. Strauss. Pennsylvania State University, University Park, Pa.

L. L. Wright. Oak Ridge National Laboratory, Oak Ridge, Tenn.

926 Influence of Timing and Method of Harvest on Rapeseed Vleld

J. Production Agriculture 4, pp. 266-272 (1991)

D. L. Thomas, M. A. Breve, P. L. Raymer. University of Georgia, Athens, Ga.

927 Blomass and Soll Nitrogen Relationshlps of a One-Year-Old Sycamore Plantation

Soil Sci. Am. J. 55, pp. 841-847 (1991)

T. J. Tschaplinski, R. J. Norby, D. E. Todd. Oak Ridge National Laboratory, Oak Ridge, Tenn.

D. W. Johnson. Desert Research Institute, Reno, Nev.

928 Physlologlcal Indicators of Nitrogen Response In Short Rotation Sycamore Plantations. I. $\mathrm{CO}_{2}$ Assimilation, Photosynthetic Pigments, and Soluble Carbohydrates

Physiol. Plant. 82, pp. 117-126 (1991)

T. J. Tschaplinski, R. J. Norby. Oak Ridge National Laboratory, Oak Ridge, Tenn.

929 Screening Herbaceous Lignocellulosic Energy Crops in Temperate Regions of the United States

Bioresource Technology 36, pp. 247-252 (1991)

A. F. Turhollow. Oak Ridge National Laboratory, Oak Ridge, Tenn

930 Windbreak Specles Performance and Management Practices as Reported by Montana and North Dakota Landowners

J. Soil and Water Conservation May-June, pp. 225-228 (1991)

G. A. Tuskan. Oak Ridge National Laboratory, Oak Ridge, Tenn.

K. Laughlin. University of Idaho, Sandpoint, Idaho

931 Role of New Wood Energy Crops In Mitigation of Fossll $\mathrm{CO}_{2}$ EmIssions Proc., 1990 Conference on Biomass for Utility Applications, pp. 87-112 (Falo Alto, Calif.:

Electric Power Research Institute, 1991)

L. L. Wright. Oak Ridge National Laboratory, Oak Ridge, Tenn.

932 The Economic Vlablilty of Short Rotation Woody Crops

Policy Implications of Greenhouse Warming Report of the Mitigation Panel. Appendix H:

Biomass, pp. H-1-H-7 (Washington, D. C.: National Academy Press, 1991)

L. L. Wright. Oak Ridge National Laboratory, Oak Ridge, Tenn. 
933 Herbaceous Energy Crops Program: Annual Progress Report for FY 1988 ORNL-6639 (November 1990)

A. F. Turnollow, J. H. Cushman, J. W. Johnston. Oak Ridge National Laboratory, Oak Ridge, Tenn.

934 Screening of Herbaceous Specles for Energy Crop Production. Final Report 1985-1990

ORNL/Sub/85-27411/5 (November 1990)

N. Wright. Geophyta, Vickery, Ohio

935 Evaluation of Potentlal Herbaceous Blomass Crops on Marginal Crops Lands: 2) Economic Potentlal. Final Report 1985-1989

ORNL/Sub/85-27412/5\&P2 (November 1990)

C. L. Dobbins, P. Preckel, A. Mdafri, J. Lowenberg-DeBoer, D. Stucky. Purdue University, West Lafayette, Ind.

936 Screening and Selection of Herbaceous Species for Blomass Production In the Midwest/Lake States. Final Report 1985-1989 ORNL/Sub/85-27410/5 (November 1990)

R. A. Pieifer, G. W. Fick, D. J. Lathwell, C. Maybee. New York State College of Agriculture and Life Sciences, Comell University, thaca, N.Y.

937 Short Rotatlon Woody Crops Program: Annual Progress Report for 1989 ORNL-6625 (August 1990)

L. L. Wright, A. R. Ehrenshatt. Oak Ridge National Laboratory, Oak Ridge, Tenn.

938 Modifying Woody Plants for Efficlent Conversion to Liquld and Gaseous Fuels

ORNL/Sub/88-SC006/1 (July 1990)

R. J. Dinus, D. R. Dimmel, R. P. Feirer, M. A. Johnson, E. W. Malcolm. Institute of Paper

Science and Technology, Atlanta, Ga.

939 Evaluation of Potentlal Herbaceous Blomass Crops on Marginal Crop Lands: 1) Agronomic Potentlal. Final Report 1985-1989 ORNL/Sub/85-27412/5\&P1 (July 1990)

J. H. Cherney, K. D. Johnson, J. J. Volenec, E. J. Kladivko, D. K. Greene. Department of Agronomy, Purdue Univ., West Lafayette, Ind.

940 Evaluation of the Potential for Using Old-Fleld Vegetation as an Energy Feodstock: Blomass VIeld, Chemical Composition, Environmenial Concerns, and Economics ORNLTM-11615 (July 1990)

J. W. Johnston, Jr. Oak Ridge National Laboratory, Oak Ridge, Tenn.

941 Selection and Improvement of Herbaceous Energy Crops for the Southeastern USA. Final Report on a Field and Laboratory Research Program for the Perlod March 15, 1985 to March 14, 1990 ORNL/Sub/85-27409/5 (July 1990)

D. I. Bransby, S. E. Sladden, D. D. Kee. Dept. of Agronomy and Soils, Auburn University, Auburn University, Ala.

942 Perennlal Species for Optimum Production of Herbaceous Blomass in the Pledmont. Final Report 1985-1989

ORNL/Sub/85-27413/5 (July 1990)

D. J. Parrish, D. D. Wolf, W. L. Daniels, D. H. Vaughan, J. S. Cundiff. Virginia Polytechnic Institute and State University, Blacksburg, Va. 
943 Improving Rapeseed Production Practices in the Southeastern United States

ORNL/Sub/86-91324/1 (April 1990)

D. L. Thomas, M. A. Breve, P. L. Raymer, N. A. Minton, D. R. Sumner. University of

Georgia, Coastal Plain Experiment Station, Titton, Ga.

$944 \mathrm{CO}_{2}$ Emissions from Production and Combustion of Fuel Ethanol from Corn

ORNLTM-11180 (May 1990)

G. Marland, A. Turhollow. Oak Ridge National Laboratory, Oak Ridge, Tenn.

945 International Transfer of Agnus, Populus, and Cellos

Biomass 22, pp. 49-62 (1990)

A. Ager, N. E. Nordh, S. Ledin, M. Ostry, M. Carlson, A. Ronnberg-Wastljung. USDA

Forest Service, North Centrai Forest Experiment Station, Rhinelander, Wis.

946 Mechanization of the Operational Aspects of Short-Rotation Forestry Biomass 22, pp. 123-33 (1990)

N. S. Christopherson, J. A. Mattson. USDA Forest Service, North Central Forest

Experiment Station, Rhinelander, Wis.

947 Chemical Control of Adventitious Root Formation in Cuttings

PGRSA Quarterly 18, pp. 1-17 (1990)

T. D. Davis, B. E. Haissig. USDA Forest Service, North Central Forest Experiment Station, Rhinelander, Wis.

948 Evaluation of Agnus Species and Hybrids

Biomass 22, pp. 21-34 (1990)

R. B. Hall, D. Burgess. lowa State University, Ames, lowa

949 Genetic Varlation and Productivity of Populus trichocarpa and Its Hybrids.

IV. Performance in Short-Rotation Copplce

Can. J. For. Res. 20, pp. 1257-64 (1990)

P. E. Heilman. Washington State University, Fuyallup, Wash.

R. F. Stettler. University of Washington, Seattle, Wash.

950 Validating the Reglonal Applicablilty of a Whole-Plant Ecophyslological Growth Process Model of Juvenlle Poplar

Proceodings, Forest Simulation Systems, ed. L. C. Wensel and G. S. Biging, pp. 97-106

(University of California, 1990)

G. E. Host, H. M. Rauscher. USDA Forest Service, North Central Forest Experiment

Station, Rhinelander, Wis.

951 Fuel Ethanol from Cellulosic Blomass

Science 251, pp. 1318-23 (1990)

L. R. Lynd. Thayer School of Engineering, Dartmouth College, Hanover, N.H.

J. H. Cushman. Oax Ridge National Laboratory, Oak Ridge, Tenn.

R. J. Nichols. Ford Motor Company, Dearborn, Mich.

C. E. Wyman. Solar Energy Research Institute, Golden, Colo.

952 The Microcomputer Scientific Series \#6: The ECOPHYS User's Manual General Technical Report NC-141 (St. Paul, Minn.: U.S. Forest Service, North Central Forest Experiment Station, 1990)

G. E. Host, H. M. Rauscher, J. G. Isebrands, R. E. Dickson, T. R. Crow, D. A. Michael. USDA Forest Service, North Central Forest Experiment Station, Rhinelander, Wis.

D. I. Dickmann. Michigan State University, East Lansing, Mich. 
953 Accelerating Energy Crop Growth vla Genetlc Techniques

Energy from Biomass and Wastes XIII, pp. 397-424 (Chicago: Institute of Gas Technology, 1990)

P. A. Layton, L. L. Wright, T. W. Doyle, J. W. Ranney, J. H. Cushman, A. F. Turhollow. Oak Ridge National Laboratory, Oak Ridge, Tenn.

954 Economic Evaluations of Optimum Rotation Age for SRIC Plantations Energy from Biornass and Wastes XIII, pp. 295-307 (Chicago: Institute of Gas Technoiogy, 1990)

C. H. Strauss, S. C. Grado, P. R. Blankenhom, T. W. Bowersox. The Pennsylvania State University, University Park, Pa.

955 Commerclallzation of Short-Rotafion Intensive Culture Tree Production In North America

Energy from Biomass and Wastes XIII, pp. 309-29 (Chicago: Institute of Gas Technology, 1990)

L. L. Wright. Oak Ridge National Laboratory, Oak Ridge, Tenn.

956 ATP Concentrations in PInus banksiana Cuttings During Adventitious Rooting

J. Plant Physiol. 136, pp. 499-502 (1990)

B. E. Haissig. USDA Forest Service, North Central Forest Experiment Station, Rhinelander, Wis.

957 Reduced Irradiance and Applled Auxin Influence Carbohydrate Relations In PInus bankslana Cuttings During Propagation

Physiologia Plantarum 78, pp. 455-61 (1990)

B. E. Haissig. USDA Forest Service, North Central Forest Experiment Station, Rhinelander, Wis.

958 Photosynthesls Patterns Durlng the Establishment Year Within two Populus Clones

Tree Physiology 6, pp. 11-27 (1990)

D. A. Michael, J. G. Isebrands, N. D. Nelson. USDA Forest Service, North Central Forest Experiment Station, Rhinelander, Wis.

D. I. Dickmann. Michigan State University, East Lansing, Mich.

959 Minimizing Disease Injury to Hybrid Poplars

J. Environ. Hort. 8, pp. 96-98 (1990)

M. E. Ostry. USDA Forest Service, North Central Forest Experiment Station, Rhinelander, Wis.

H. Ė. McNabb, Jr. lowa State University, Ames, lowa

960 Cost Parameters Affecting Multiple Rotation SRIC Blomass Systems Appl. Biochem. Biotech. 24/25, pp. $721-33$ (1990)

C. H. Strauss, S. C. Grado, P. R. Blankenhorn, T. W. Bowersox. The Pennsylvania State University, University Park, Pa.

961 Woody Blomass Production Costs in the United States: An Economic Summary of Commerclal Populus Plantation Systems

Solar Energy 45, pp. 105-10 (1990)

C. H. Strauss. The Pennsylvania State University, University Park, Pa.

L. L. Wright. Oak Ridge National Laboratory, Oak Ridge, Tenn. 
962 A Review of Blomass Quallty Research Relevant to the Use of Poplar and WIllow for Energy Conversion

Biomass 21, pp. 163-88 (1990)

W. A. Kenney. University of Toronto, Ontario, Canada

L. Sennerby-Forsse. Swedish University of Agricultural Sciences, Uppsula, Sweden

P. A. Layton. Oak Ridge National Laboratory, Oak Ridge, Tenn.

963 Economlc Evaluations for Short-Rotation Blomass Production Systems

Biomass 22, pp. 135-44 (1990)

D. C. Lothner. USDA Forest Service, North Central Forest Experiment Station,

Rhinelander, Wis.

964 Copplcing Success of Young Eucalyptus sallgna in Hawall

Biomass 23, pp. 137-48 (1990)

T. W. Bowersox. The Pennsylvania State University, University Park, Pa.

T. H. Schubert, R. F. Strand. USDA Forest Service, Pacific Northwest Forest Experiment

Station, Portland, Ore.

C. D. Whitesell. BioEnergy Development Corp., Hilo, Hawaii

965 Natlonal Winter Rapeseed Variety Trlal 1988-89

Miscellaneous Series No. 130 (Moscow, Idaho: University of Idaho, 1990)

K. A. Mahler, D. L. Auld, comps. University of Idaho, Moscow, Idaho

966 Blotechnology in Blomass Crop Production. The Relationship of Biomass Production and Plant Genetic Engineering

ORNL/M-978 (December 1989)

D. E. Harry. University of Illinois Urbana-Champaign, Urbana, III.

R. R. Sederoff. North Carolina State University, Raleigh, N.C.

967 Short Rotation Woody Crops Program: Annual Progress Report for 1988 ORNL-6594 (October 1989)

L. L. Wright, T. W. Doyle, P. A. Layton, J. W. Ranney. Oak Ridge National Laboratory, Oak

Ridge, Tenn.

968 Improved Conversion of Herbaceous Blomass to Blofuels: Potentlal for Modification of Key Plant Characteristics. Final Report on a Llterature Reviow and Survey

ORNL/Sub/88-SC011/1 (October 1989)

S. E. Sladden, D. I. Bransby. Aubum University, Auburn, Ala.

969 The SRWCP Database Management System: Users Gulde, Data Definitions, and Source Code

ORNLTM-10820 (February 1989)

A. R. Ehrenshaft, L. L. Wright. Oak Ridge National Laboratory, Oak Ridge, Tenn.

970 Short Rotation Woody Crops Program Publications and Presentations ORNL/TM-10848 (February 1989)

A. R. Ehrenshaft. Oak Ridge National Laboratory, Oak Ridge, Tenn.

971 Herbaceous Energy Crops Program: Annual Progress Report for FY 1987 ORNL-6514 (January 1989)

J. H. Cushman, A. F. Turhollow, J. W. Johnston. Oak Ridge National Laboratory, Oak

Ridge, Tenn. 
972 Quick Estimates of Root Length, Using a Video Image Analyzer Canadian Joumal of Forest Research 19, pp. 335-40 (1989)

M. Curningham. University of Tennessee, Knoxville, Tenn. M. B. Adams, R. J. Luxmoore, W. M. Post, D. L. DeAngelis. Oak Ridge National Laboratory, Oak Ridge, Tenn.

973 No-TIII Establlshment of Perennlal, Warm-Season Grasses for Blomass Production

Biomass 20, pp. 209-17 (1989)

D. D. Wolf, D. J. Parrish, W. L. Daniels, J. R. McKenna. Virginia Polytechnic Institute and State University, Blacksburg, Va.

974 Herbaceous Crops on Marginal Sites Erosion and Economics Biomass 29, pp. 199-208 (1989)

D. H. Vaughan, J. S. Cundiff, D. J. Parrish. Virginia Polytechnic Institute and State University, Blacksburg, Va.

975 Allozyme Varlation in Black Locust (Robinia pseudoacacla) Can. J. For. Research 19, pp. 471-79 (1989)

S. E. Surles, J. L. Hamrick, B. C. Bongarten. University of Georgia, Athens, Ga.

976 Shoot Culture Dynamics of Six Populus Clones

Troe Physiology 5, pp. 219-27 (1989)

J. C. Sellmer, B. E. Haissig. USDA Forest Service, North Central Forest Experiment Station, Rhinelander, Wis.

B. H. McCown. University of Wisconsin, Madison, Wis.

977 Specles Screening and Blomass Trials of Woody Plants in the Seml-Arld Southwest Unlted States

Biomass 18, pp. 15-29 (1989)

R. D. Kirmse, J. T. Fisher. Energy/Development International, Washington, D.C.

978 Physiological, Morphological and Anatomical Components of Hybrid Vigor In Populus

Structural and Functional Responses to Environmental Stresses, ed. K. H. Kreeb, H. Richter, and T. M. Hirickley, pp. 199-217 (The Hague, The Netherlands: SPB Academic Publishing bV, 1989)

T. M. Hinckley, R. Ceulemans, J. M. Dunlap, A. Figliola, P. E. Heilman, J. G. Isebrands, G. Scarascia-Mugnozza, P. J. Schulte, B. Smith, R. F. Stettler, E. Van Volkenburg, B. M. Wiard. University of Washington, Seattle, Wash.

979 Using N2-flxing Alblzla to Increase Growth of Eucalyptus Plantations in Hawall

Forest Science 35, pp. 64-75 (1989)

D. S. DeBell, C. D. Whitesell, T. H. Schubert. USDA Forest Service, Pacitic Northwest Station, Portland, Ore.

980 Blomass Production from Selected Herbaceous Specles in the Southeastern USA

Biomass 20, pp. 187-97 (1989)

D. I. Bransby, C. Y. Ward, P. A. Rose, S. E. Sladden, D. D. Kee. Aubum University, Auburn, Ala. 
981 The Potentlal of Vegetable Oll as an Alternate Source of Liquid Fuel for Agriculture in the Paclfic Northwest VI

Miscellaneous Series No. 121 (Moscow, Idaho: University of Idaho, 1989)

D. L. Auld, R. A. Korus, C. L. Peterson. University of Idaho, Moscow, Idaho

982 Ethanol Production and the Environment

Energy 14, pp. 451-68 (1989)

D. B. Hunsaker, Jr., J. F. McBrayer. Oak Ridge National ' 'aboratory, Oak Ridge, Tenn.

J. L. Elmore. PEER Consultants, Oak Ridge, Tenn.

983 Photosynthetlc Relnvigoration of Leaves Following Shoot Decapltation and Accelerated Growth of Copplce Shoots

Physiol. Plant. 75, pp. 157-65 (1989)

T. J. Tschaplinski. Automated Sciences Group, Inc., Oak Ridge, Tenn.

T. J. Blake. University of Toronto, Toronto, Ontario, Canada

984 The Role of Sink Demand In Carbon Partitioning and Photosynthetic Relnvigoration Following Shoot Decapitation

Physiol. Plant. 75, pp. 166-73 (1989)

T. J. Tschaplinski. Automated Sciences Group, Inc., Oak Ridge, Tenn.

T. J. Blake. University of Toronto, Toronto, Ontario, Canada

985 Comparisons Among Populus Clones and Intenslve Culture Conditlons Using an Energy Conversion Model

Forest Ecology and Management 27, pp. 129-47 (1989)

J. J. Landsberg. Commonwealth Scientific and Industrial Research Organization,

Australia

L. L. Wright. Oak Ridge National Laboratory, Oak Ridge, Tenn.

986 Water Stress Tolerance and Late-Season Organic Solute Accumulation In Hybrid Poplar

Can J. Bot. 67, pp. 1681-88 (1989)

T. J. Tschaplinski. Automated Sciences Group, Inc., Cak Ridge, Tenn.

T. J. Blake. University of Toronto, Toronto, Ontario, Canada

987 Correlation Between Early Root Production, Carbohydrate Metabollsm, and Subsequent Dry Matter Production in Hybrid Poplar

Can. J. Bot. 67, pp. $2168-74$ (1989)

T. J. Tschaplinski. Automated Sciences Group, Inc., Oak Ridge, Tenn.

T. J. Blake. University of Toronto, Toronto, Ontario, Canada

988 Commerclalization of Short-Rotation Intensive Culture Tree Production in North America

Energy from Biomass and Wastes XII, ed. D. L. Klass, pp. 261-74 (Chicago: Institute of Gas Technology, 1989)

L. L. Wright. Oak Ridge National Laboratory, Oak Ridge, Tenn.

989 Water Relatlons and Photosynthetic Capacity as Determinants of Productivity In Hybrid Poplar Cultivars

Can. J. Bot. 67, pp. 1689-97 (1989)

T. J. Tschaplinski. Automated Sciences Group, Inc., Oak Ridge, Tenn.

T. J. Blake. University of Toronto, Toronto, Ontario, Canada 
990 Cattall (Typha Spp.) Blomass Production. Stand Management and Sustalnable Ylelds

ORNL/Sub/84-89674/1 (December 1988)

D. C. Pratt, D. R. Dubbe, E. G. Garver, W. D. Johnson. University of Minnesota, St. Paul and Crookston, Minn.

991 Productivity of Wet Solls: Blomass of Cultivated and Natural Vegetation ORNL/Sub/84-18435/1 (December 1988)

C. A. Johnston. Environmental Consulting, Duluth, Minn.

992 Short Rotation Woody Crops Program Annual Progress Report for 1987 ORNL-6440 (August 1988)

J. W. Ranney, A R. Ehrenshaft, P. A. Layton, W. A. MCNabb, L. L. Wright. Oak Ridge

National Laboratory, Oak Ridge, Tenn.

993 Hydrocarbons and Energy from Plants, Final Report 1984-1987

ORNL/Sub/84-90435/1 (August 1988)

M. Calvin, J. W. Otvos, S. E. Taylor, E. K. Nemethy, C. L. Sknunud, D. R. Hawkins, R. Lago.

University of Califomia and Lawrence Berkeley Laboratory, Berkeley, Calif.

994 Second-Year Growth and Productivity for Potentlal Herbaceous Energy Crops in the Southeast and Midwest/Lake States

ORNLTM-10626 (July 1988)

A. F. Turhollow. Oak Ridge National Laboratory, Oak Ridge, Tenn.

995 Economics of Vegetable Oll Processing

ORNL/Sub/87-SA185/1 (May 1988)

R. Scheithauer, K. Dripchak. JAYCOR, Vienna, Va.

996 Woody Specles for Blomass Production In Florlda: Final Report 19831988

ORNL/Sub/81-09050/7 (February 1988)

D. L. Rockwood, D. R. Dippon, M. S. Lesney. University of Florida, Gainesville, Fla.

997 The Potentlal of Blotechnology In the Blomass Production Program ORNLM-606 (January 1988)

D. D. Ellis, B. H. Mocown. University of Wisconsin, Madison, Wis.

998 Impact and Control of Septorla musiva on Hybrid Poplars

Gen. Tech. Rep. NC-133 (St. Paul, Minn.: USDA Forest Service, 1988)

M. E. Ostry, L. F. Wilson. USDA Forest Service, North Central Forest Experiment Station, Rhinelander, Wis.

H. S. McNabb, Jr. lowa State University, Ames, lowa

999 LInking Energy Crop Production to Conversion: The Case of Herbaceous LIgnocellulosic Crops to Ethanol

RERIC International Energy Joumal 10, pp. 41-49 (1988)

A. F. Turhollow, J. W. Johnston, J. H. Cushman. Oak Ridge National Laboratory, Oak Ridge, Tenn.

1000 A Cost Analysis of Alternate Blomass Supply Systems

For. Prod. 38, pp. 47-51 (1988)

C. H. Strauss, P. R. Blankenhom, T. W. Bowersox, S. C. Grado. The Pennsytvania State University, University Park, $\mathrm{Pa}$. 
1001 Increased Herblcide Tolerance of In vitro Selected Hybrid Poplar Somatic Cell Genetics of Woody Plants, pp. 183-89 (Dordrecht, The Netherlands: Klüwer Academic Publishers, 1988)

C. H. Michler, B. E. Haissig. USDA Forest Service, North Central Experiment Station, Rhinelander, Wis.

1002 Production of Cattall (Typha spp.) Blomass In Minnesota, USA Biomass 17, pp. 79-104 (1988)

D. R. Dubbe, E. G. Garver, D. C. Pratt. University of Minnesota, St. Paul, Minn.

1003 Chemical Composition of Herbaceous Grass and Legumes Species Biomass 17, pp. 215-39 (1988)

J. H. Cherney, K. D. Johnson, J. J. Volenec, K. S. Anliker. Purdue Universiky, West Lafayette, Ind.

1004 SRIC: integration of Production and Harvesting System Costs Proceedings of the International Energy Agency Workshop on Economic Evaluations of Short-Rotation Biomass Energy Systerns, IEABAATask II, Duluth, Minn., August 11-13, 1987, pp. 115-50 (Toronto: University of Toronto Press, 1988)

S. L. Woodfin, D. T. Curtin. Tennessee Valley Authority, Norris, Tenn.

L. L. Wright. Oak Ridge National Laboratory, Oak Ridge, Tenn.

1005 Valldatlon arid Standardization of SRIC Production Costs Proceedings of the International Energy Agency Workshop on Economic Evaluations of Short-Rotation Biomass Energy Systems, IEABA Task II, Duluth, Minn., August 11-13, 1987, pp. 230-37 (Toronto: University of Toronto Press, 1988)

L. L. Wright, J. W. Ranney. Oak Ridge National Laboratory, Oak Ridge, Tenn.

1006 Influence of Site Condition, Fertllization and Spacing on Short Rotation Hardwood Copplce and Seedling Vields

Biomass 16, pp. 183-98 (1988)

S. J. Torreano, D. J. Frederick. North Carolina State University, Raleigh, N.C.

1007 Populus trichocarpa x Populus deltoldes Hybrids for Short Rotation Culture: Varlation Patterns and Four-Vear Field Performance

Can. J. For. Res. 18(6), pp. 745-53 (1988)

R. F. Stettler, R. C. Fenn, P. E. Heilman, B. J. Stanton. University of Washington, Seattle, Wash.

1008 Nutrient Relations in Copplced Black Cottonwood and Red Alder Plant and Soil 106, pp. 171-77 (1988)

M. A. Radwan, D. S. DeBell. USDA Forest Service, Pacific Northwest Experiment Station, Portland, Ore.

1009 Growth and Development During the Establlshment Year of Two Populus Clones With Contrasting Morphology and Phenology

Tree Physiology 4, pp. 139-52 (1988)

D. A. Michael, J. G. Isebrands, N. D. Nelson. USDA Forest Service, North Central Experiment Station, Rhinelander, Wis.

D. I. Dickmann. Michigan State University, East Lansing, Mich.

1010 Silver Maple Seed Sources for Increased Blomass Production North. J. Appl. For. 5(3), pp. 180-84 (1988)

R. F. Kopp, W. A. Geyer, W. R. Lovett. Kansas State University, Manhattan, Kans. 
1011 Nitrogen Fertilization of Young Yellow.Poplar and Loblolly Pine Plantatlons at Differing Frequencles

Soil Sci. Soc. Am. J. 52, pp. 1468-77 (1988)

D. W. Johnson, D. E. Todd. Oak Ridge National Laboratory, Oak Ridge, Tenn.

1012 The Effects of Leaching and Whole-Tree Harvesting on Cation Budgets of Several Forests

J. Environ. Qual. 17, pp. 418-24 (1988)

J. ':. Johnson, J. M. Kelly, H. Van Miegroet. Oak Ridge National Laboratory, Oak Ridge, Tenn.

W. T. Swank. Cowrota Hydrologic Lab., Otto, N.C.

D. W. Cole. University of Washington, Seattle, Wash.

J. W. Hombeck, R. S. Pierce. USDA Forest Service, Northeastern Forest Experiment Station, Durham, N.H.

D. Yan Lear. Clemson University, Clemson, S.C.

1013 Genetlc Varlation in Photosynthetic Traits Among Populus Clones in Relation to Yleld

Plant Physiol. Biochem. 26(4), pp. 427-37 (1988)

J. G. Isebrands. USDA Fores. Service, North Central Experiment Station, Rhinelander, Wis.

R. Coulemans, B. Wiard. Universin; of Washington, Seattle, Wash.

1014 Blomass and Nitrogen Dynamics of Hybrid Poplar on Two Different Solls: Implications for Fortllization Strategy

Can. J. For. Res. 18, pp. 233-30 (1988)

E. A. Hansen, R. A. MCLaughlin. USDA Forest Service, North Central Experiment

Station, Rhinelander, Wis.

P. E. Pope. Purdue University, West Lafayette, Ind.

1015 Irrigating Short Rotation Intensive Culture Hybrid Poplars Biomass 16, pp. 237-50 (1988)

E. A. Hansen. USDA Forest Service, North Central Experiment Station, Rhinelander, Wis.

1016 Comparlson of Seedling Contalners on Growth and Survival of Prosopis alba and Leucaena leucocephala in Seml-Arid Conditions

For. Ecol. Manage. 24, pp. 177-82 (1988)

P. F'iker, C. Wiesman, D. Smith. Texas A\&I University, Kingsville, Texas

1017 A Guide to Using "agression Equations for Estimating Tree Blomass North. J. Appl. E... o, pp. 15-22 (1988)

T. R. Crow. USDA Forest Service, North Central Experiment Station, Rhinelander, Wis.

1018 Natlonal WInter Rapeseed Varlety Trlal 1986-87

Misc. Series Bull. No. 113 (Moscow, Idaho: University of !daho, 1988)

K. A. Mahler, D. L. Auld, comps. University of Idaho, Moscow, Idaho

1019 Effects of Management Strategy and Site on Selected Properties of First Rotation Populus Hybrid NE-388

Wood Fiber Sci. 20(1): pp. 74-81 (1988)

P. R. Blankenhom, T. W. Bowersox, C. H. Strauss, G. L. Stimely, L. R. Stover, M. L.

DiCola. Pennsytvania State University, University Park, Pa. 

$1020 \begin{aligned} & \text { Financial and Energy Costs of Supplying Woody Blomass to Conversion } \\ & \text { Sites }\end{aligned}$

Appl. Biochem. Biotech. 18, pp. 217-30 (Clitton, New Jersey: Humana Press, 1988)

C. H. Strauss, P. R. Blankenhom, T. W. Bowersox, S. C. Grado. Pennsylvania State

University, University Park, $\mathrm{Pa}$.

1021 Effects of Whole-Tree and Stem-Only Clear-Cutting on Postharvest Hydrologic Losses, Nutrient Capltal, and Site Productivity Forest Sci. 42, pp. 412-28 (1988)

L. K. Mann, D. W. Johnson, D. C. West. Oak Ridge National Laboratory, Oak Ridge,
Tenn.

D. W. Cole. College of Forest Resources, Seattle, Wash.

J.W. Hornbeck. USDA Forest Service, Northeastern Forest Experiment Station, Durham,

N.H.

C. W. Martin. Hubbard Brook Experimental Forest, Campton, N.ri'.

H. Riekerk. School of Forest Resources and Conservation, Gainesville, Fla.

C. T. Smith. University of New Hampshire, Durham, N.H.

W. T. Swank. Coweeta Hydrologic Laboratory, Otto, N.C.

L. M. Tritton. Consultant to Oak Ridge National Laboratory, Oak Ridge, Tenn.

D. H. Van Lear. vepartment of Forestry, Clemson, S.C.

1022 Cultural and Management Practices for the Chinese Tallow Tree as a Blomass Fuel Source

ORNL/Sub/81-09059/1 (December 1987)

J. R. Cowles, H. W. Scheid. University of Houston, Houston, Texas 1023 Short Rotatlon Woody Crops Program: Annual Progress Report for 1986 J. W. Ranney, L. L. Wright, P. A. Layton, W. A. McNabb. Oak Ridge National Laboratory,
Oak Ridge, Tenn.

C. R. Wenzel. Science Applications International Corp., Oak Ridge, Tenn.

D. T. Curtin. Tennessee Valley Authority, Norris, Tenn. 1024 Herbaceous Energy Crops Program: Annual Progress Report for FY 1986

J. H. Cushman, A. F. Turhollow, J. W. Johnston, Jr. Oak Ridge National Laboratory, Oak
Ridge, Tenn.

1025 Characterization of the Southwest Unlted States for the Production of Blomass Energy Crops

ORNLTM-10203 (March 1987)

M. S. Salk. Oak Ridge National Laboratory, Oak Ridge, Tenn.

A. G. Folger. Solar Energy Research Institute, Golden, Colo. 1026 Early Growth and Nutrient Status of Eucalyptus saligna as Affected by
Nitrogen and Phosphorus Fertllization

Aust. For. Res. 17, pp. 203-14 (1987)

R. S. Yost, D.S. DeBell. USDA Forest Service, Pacific Northwest Experiment Station,

Portland, Ore.

C. D. Whitesell, S. C. Miyasaka. BioEnergy Development Corp., Hilo, Hawaii 
1027 Abscisic Acld Relations and the Response of Populus trichocarpa Stomata to Leaf Water Potential

Tree Physiol. 3, pp. 103-13 (1987)

P. J. Schulte. University of Washington, Seattle, Wash.

T. M. Hinckley. USDA Forest Service, North Central Experiment Station, Rhinelander, Wis.

1028 A Simple Method for Evaluating Whole-Plant Cold Hardiness Tree Plant. Notes 38(2), pp. 16-18 (1987)

W. J. Rietveld, R. W. Tinus. USDA Forest Service, North Central Experiment Station, Rhinelander, Wis.

1029 Biomass Energy and Soll Erosion: Assessment of Resource Costs Biomass 14, pp. 15-38 (1987)

D. Pimentel, J. Krummel. Oak Ridge National Laboratory, Oak Ridge, Tenn.

1030 Wood Energy Plantation Economics in the Great Plains

J. Energy Engineering 13(3), pp. 92-101 (1987)

R. D. Perlack. Oak Ridge National Laboratory, Oak Ridge, Tenn.

W. A. Geyer. Kansas State University, Manhattan, Kans.

1031 Development of Eucalyptus Clones for a Summer Ralnfall Environment with Perlodic Severe Frosts

New For. 3, pp. 197-205 (1987)

G. F. Meskimen, D. L. Rockwood, K. V. Reddy. Florida State University, Gainesville, Fla.

1032 Influence of Auxins, Thlamine and Fungal Drenches on the Rooting of Prosopls alba Clone B2V50 Cuttings

J. Hortic. Science 62(1), pp. 97-100 (1987)

S. Klass, J. Wright, P. Felker. Texas A\&I University, Kingsville, Texas

1033 Varlation in Growth of Red Alder Familles In Relation to Shallow Water Table Levels

For. Sci. 33(1), pp. 224-29 (1987)

D. D. Hook, M. D. Murray, D. S. DeBell, B. C. Wilson. USDA Forest Service, Pacific

Northwest Experiment Station, Portland, Ore.

1034 Determining $\mathrm{CO}_{2}$ Exchange Rate as a Function of Photosynthetic Photon Flux Density

Photosynthetica 21, pp. 98-101 (1987)

P. H. Hansen. Oak Ridge National Laboratory, Oak Ridge, Tenn.

R. E. McRoberts, J. G. Isebrands. USDA Forest Service, North Central Experiment

Station, Rhinelander, Wis.

R. K. Dixon. University of Minnesota, St. Paul, Minn.

1035 Trends In the Use of TIssue Culture In Forest Improvement Biotechnology 5, pp. 52-59 (1987)

B. E. Haissig, N. D. Nelson, G. H. Kidd. USDA Forest Service, North Central Experiment Station, Rhinelander, Wis.

1036 Correlations Between Blomass Productivity and Soll and Plant Tissue Nutrient Concentrations for Leucaena leucocephala $(K-8)$ Growing on Calcareous Solls

For. Ecol. Manage. 18, pp. 241-50 (1987)

E. L. Glumac, P. Felker, I. Reyes. Texas A\&I University, Kingsville, Texas 
1037 A Comparison of Cold Tolerance and Blomass Production In Leucaena leucocephala, L. pulverulenta and L. retusa

For. Ecol. Manage. 18, pp. 251-71 (1987)

E. L. Glumac, P. Felker, I. Reyes. Texas A\&I University, Kingsville, Texas

1038 Preemergent Herbicide Trials With Direct-Seeded Black Locust Grown In Different Solls

J. Arboriculture 13(4), pp. 105-07 (1987)

W. A. Geyer, L. Melichar, C. E. Long. Kansas State University, Manhattan, Kans.

1039 Agrobacterlum Medlated Transformation and Regeneration of Populus Mol. Gen. Genet. 206, pp. 192-99 (1987)

D. J. Frederick, T. Tew, A. Clark III, D. R. Phillips. North Carolina State University, Raleigh, N.C.

1040 Dlurnal Changes In Leaf Chemical Constltuents and 14C-Partitioning In Cottonwood

Tree Physiol. 3, pp. 157-71 (1987)

R. E. Dickson. USDA Forest Service, North Central Experiment Station, Rhinelander, Wis.

1041 A Reglonal Carbon Storage Simulation for Large-Scale Blomass Plantations 1

Ecological Modelling 36, pp. 171-80 (1987)

W. P. Cropper, Jr., K. C. Ewel. Florida State University, Tallahassee, Fla.

1042 Nutrlent Export by Leaching and Whole-Tree Harvesting in a Loblolly PIne and Mixed Oak Forest

Plant \& Soil 102, pp. 99-109 (1987)

D. W. Johnson, D. E. Todd. Oak Ridge National Laboratory, Oak Ridge, Tenn.

1043 The Location Theory of the Plantation

J. Reg. Sci. 27, pp. 157-82 (1987)

D. W. Jones, J. R. Krummel. Oak Ridge National Laboratory, Oak Ridge, Tenn.

1044 Nitrogen Cycllng Models and Thelr Application to Forest

Procoedings of the IEABBA Task II Workshop on Productivity, Technology, Economics, and Nutrient Cycling, Kingston, Ontario, Canada, May 20-23, 1986, pp. 27-36 (Canadian Forestiy Service, 1987)

D. W. Johnson, V. H. Dale. Oak Ridge National Laboratory, Oak Ridge, Tenn.

1045 Blomass and Nitrogen Dynamics In an Irrigated Hybrid Poplar Plantation Forest Ecology and Management 18, pp. 169-88 (1987)

R. A. McLaughlin, E. A. Hansen. USDA Forest Service, North Central Experiment Station, Rhinelander, Wis.

P. E. Pope. Purdue University, West Lafayette, Ind.

1046 Hardwood Energy Crops: The Technology of Intensive Culture J. For. 85, pp. 17-28 (1987)

J. W. Ranney, L. L. Wright, P. A. Layton. Oak Ridge National Laboratory, Oak Ridge, Tenn.

1047 Economics of Short Rotation Intenslve Culture for the Production of Wood Energy Feedstocks Energy 12, pp. 1217-26 (1987)

R. D. Perlack, J. W. Ranney. Oak Ridge National Laboratory, Oak Ridge, Tenn. 
1048 Landscape Patterns in a Disturbed Environment OIKOS 48, pp. 321-24 (1987)

J. R. Krummel. Argonne National Laboratory, Argonne, III.

R. H. Gardner, R. V. O'Neill, P. R. Coleman. Oak Ridge National Laboratory, Oak Ridge, Tenn.

G. Sugihara. University of Southem Caliiomia, San Diego, Calif.

1049 Prospects for Commerclalization of Eucalyptus Blomass Plantations in Florida

Energy from Biomass and Wastes $X, \theta d$. D. L. Klass, pp. 233-49 (Chicago: Institute of Gas Technology, 1987)

D. L. Rockwood, D. R. Dippon. University of Florida, Gainesville, Fla.

1050 The Role of Genetic Improvement in the Short Rotation Woody Crops Program

Energy from Biomass and Wastes $X$, ed. D. L. Klass, pp. 133-54 (Chicago: Institute of Gas Technology, 1987)

P. A. Layton, L. L. Wright. Oak Ridge National Laboratory, Oak Ridge, Tenn.

1051 Research Strategy for Attaining High Vlelding Populus Energy Plantations

Energy from Biomass and Wastes $X$, ed. D. L. Klass, pp. 121-32 (Chicago: Institute of Gas Technology, 1987)

E. A. Hansen. USDA Forest Service, North Central Experiment Station, Rhinelander, Wis.

1052 Tissue Culture-Based Blotechnology for Populus Clones Energy from Biomass and Wastes $X$, ed. D. L. Klass, pp. 155-76 (Chicago: Institute of Gas Technology, 1987)

B. E. Haissig. USDA Forest Senvice, North Central Experiment Station, Rhinelander, Wis. 


\section{BIOTECHNOLOGY}

1053 Advanced Bloprocessing Concepts: Technology Needs and R\&D Opportunities Prellminary Assessment

ORNL/M-2629 (January 15, 1993)

B. H. Davison, C. D. Scott, T. C. Scott. Oak Ridge National Laboratory, Oak Ridge, Tenn.

1054 A Proposed Blparticle Fluldized-Bed for Lactic Acld Fermentation and Simultaneous Adsorption

Biotechnology and Bioengineering 39(3), pp. 365-68 (1992)

B. H. Davison, C. D. Scott. Oak Ridge National Laboratory, Oak Ridge, Tenn.

1055 Technoeconomic Evaluation of the Extractlve Fermentation of Butanol as a Gulde to Research in This Area of Blotechnology

ORNL/TM-11851 (September 1991)

R. M. Busche. Bio En-Gene-Er Assoc., Inc., Wilmington, Del.

1056 The UItImate Ethanol: Technoeconomic Evaluation of Ethanol Manufacture, Comparing Yeast vs Zymomonas Bacterlum Fermentations

R. M. Busche. Bio En-Gene-Er Associates, Inc., Wilmington, Del.

C. D. Scott, B. H. Davison. Oak Ridge National Laboratory, Oak Ridge, Tenn.

L. R. Lynd. Dartmouth College, Hanover, N.H.

1057 Phase Holdup and Dispersion in a Three-Phase Fluldized-Bed Bloreactor with Low-Density Gel Beads

Annals of the New York Academy of Sciences 589, pp. 670-77 (1990)

B. H. Davison. Oak Ridge National Laboratory, Oak Ridge, Tenn.

1058 Use of Immobllized Microblal Membrane Fragments to Reduce Oxygen Content and Enhance the Acetone-Butanol Fermentation Biotechnol. Prog. 6, pp. 210-13 (1990)

F. Godia. Unitat d'Enginyeria Quimica, Universitat Autonoma de Barcelona, Spain

H. I. Adler. Oak Ridge Associated Universities, Oak Ridge, Tenn.

B. H. Davison, C. D. Scott. Oak Ridge National Laboratory, Oak Ridge, Tenn.

1059 Gas Holdup In Three-Phase Immobllized Cell Bloreactors Appl. Biochem. Biotech. 24/25, pp. 485-96 (1990)

R. Bajpai. University of Missouri-Columbia, Columbia, Mo.

J. E. Thompson, B. H. Davison. Oak Ridge National Laboratory, Oak Ridge, Tenn.

1060 Corn Products as Chemical Feedstocks: The Corn Refinery

Proceedings First Annual Corn Utilization Conference, St. Louis, Mo., June 11-12,

1987. pp. 286-99 (National Com Growers Association, 1989)

C. D. Scott. Oak Ridge National Laboratory, Oak Ridge, Tenn.

1061 Dlspersion and Holdup In a Three-Phase Fluldlzed-Bed Bloreactor Appl. Biochem. Biotechnol. 20-21, pp. 449-60 (Clifton, N.J.: Humana Press, 1989) B. H. Davison. Oak Ridge National Laboratory, Oak Ridge, Tenn. 1062 Solute Diffusion In Blocatalyst Gel Beads Containing Blocatalysts and

Enzyme Microb. Technol. 11, pp. 258-63 (1989)

C. D. Scott, J. A. Woodward, J. E. Thompson. Oak Ridge National Laboratory, Oak Ridge, 
1063 Operabllity and Feaslbillty of Ethanol Production by Immobllized Zymomonas moblils in a Fluldized-Bed Bloreactor

Appl. Biochem. Biotechnol. 18, pp. 19-34 (Clitton, N.J.: Humana Press, 1988)

B. H. Davison, C. D. Scott. Oak Ridge National Laboratory, Oak Ridge, Tenn.

1064 Proceedings of the Ninth Symposium on Blotechnology for Fuels and Chemlcals

Appl. Biochem. Biotechnol. 17-18 (Clifton, N.J.: Humana Press, 1988)

C. D. Scott, ed. Oak Ridge National Laboratory, Oak Ridge, Tenn.

1065 Plant Cell Tissue Culture A Potentlal Source of Chemicals

ORNL/TM-10521 (August 1987)

C. D. Scott. Oak Ridge National Laboratory, Oak Ridge, Tenn.

D. K. Dougall. University of Tenniessee, Knoxville, Tenn.

1066 Dispersed-Phase Adsorbents for Blotechnology Applicatlons

Presented at the Second International Conference on Separation Technology, Schloss

Elmau, Klais, Federal Republic of Germany, April 26-30, 1987

C. D. Scott. Oak Ridge National Laboratory, Oak Ridge, Tenn.

1067 Techniques for Producing Monodlspersed Blocatalyst Besds for Use In Columnar Bloreactors

Ann. N.Y. Acad. Science 501, pp. 487-93 (1987)

C. D. Scott. Oak Ridge National Laboratory, Oak Ridge, Tenn.

1068 Immobllized Cells: A Review of Recent Literature

Enzyme Microb. Technol. 9, pp. 66-73 (1987)

C. D. Scott. Oak Ridge National Laboratory, Oak Ridge, Tenn. 


\title{
CONTINUOUS CHROMITOGRAPHY IN MULTICOMPONENT SEPARATIONS
}

\author{
980 Advanced Technlques for Energy-Efficlent Industrlal-Scale Continuous \\ Chromatography \\ ORNLTM-11282 (November 1989) \\ J. P. DeCart Il. Dow Chemical Company, Midland, Mich. \\ G. Carta. University of Virginia, Charlottesville, Va. \\ C. H. Byers. Oak Ridge National Laboratory, Oak Ridge, Tenn.
}
981 Large-Scale Separation of Amino Acids by Continuous Displacement Chromatography DOE/OR/21400-T468* (October 1989)
J. P. DeCart II. Dow Chemical Company, Midland, Mich.
G. Carta. University of Virginia, Charlottesvile, Va.
C. H. Byers. Oak Ridge National Laboratory, Oak Ridge, Tenn.

982 An Economic and Energy Evaluation of the Replacement of Conventional Technology with Continuous Chromatography in the Dump Leaching of Copper Ores DOE/OR/21400-T35* (February 1989)

C. H. Byers, J. M. Begovich. Oak Ridge National Laboratory, Oak Ridge, Tenn.

J. M. Holmes. JMH Associates, Knoxville, Tenn.

983 Novel Applications of Continuous Annular Chromatography: Separation of Sugars

New Directions in Sorption Technology, ed. G. E. Keller II and R. T. Yang, pp. 342-49

(Stoneham, Mass.: Buttersworth, 1989)

A. J. Howard. University of Florida, Gainesville, Fla.

G. Carta. University of Virginia, Charbottesvile, Va.

C. H. Byers. Oak Ridge National Laboratory, Oak Ridge, Tenn.

984 Pllot-Scale Studies of Sugar Separations by Continuous Chromatography Appl. Biochem. Biotechnol. 20-21, pp. 635-54 (Clitton, N.J.: Humana Press, 1989)

C. H. Byers, W. G. Sisson. Oak Ridge National Laboratory, Oak Ridge, Tenn.

J. P. DeCarli, G. Carta. University of Virginia, Chartottesville, Va.

985 The Use of Gradient Elution In Optimizing Continuous Annular Ion Exchange Chromatography with Applications to Metal Separatlons Ion Exchange for IndListry, Proceedings IEX '88, Cambridge, Great Britain, July 17-22, 1988, ed. M. Streat, pp. 424-42 (Chichester: E. Horwood, 1989)

C. H. Byers, W. G. Sisson. Oak Ridge National Laboratory, Oak Ridge, Tenn.

J. P. DeCarli. University of Virginia, Charbottesville, Va.

\section{Separation of Metals by Continuous Annual Chromatography with Step Elution \\ Chem. Eng. Comm. 79, pp. 207-27 (1989) \\ J. P. DeCarli, G. Carta. University of Virginia, Charlottesville, Va. \\ C. H. Byers, W. G. Sisson. Oak Ridge National Laboratory, Oak Ridge, Tenn.}

\footnotetext{
"Available from the National Technical Information Service, U.S. Department of Commerce, 5285 Port Royal Road, Springfield, Virginia 22151.
} 
987 An Economic and Energy Evaluatlon of the Replacement of Conventional Technology with Continuous Chromatography in the Production of HighFructose Sugar

DOE/OR/21400-T352* 'October 1988)

C. H. Byers. Oak Ridg: National Laboratory, Oak Ridge, Tenn.

J. M. Holmes. JMH A' sociates, Knoxville, Tenn.

988 Application of Continuous Annual Chromatography to Size-Exclusion Separatlons

CHEMTECH 18, pp. 498-502 (August 1988)

W. G. Sisson, J. M. Begovich, C. H. Byers, C. D. Scott. Oak Ridge National Laboratory, Oak Ridge, Tenn.

989 An ASPEN Simulation of Fuel Production by Hydrolysis of Woody Blomass

Journal of Applied Biochemistry and Biotechnology 18, pp. 143-57 (January 1988)

C. H. Byers. Oak Ridge National Laboratory, Oak Ridge, Tenn.

990 Separation of Sugars by Continuous Annular Chromatography

ORNL/TM-10318 (August 1987)

A. J. Howard. University of Florida, Gainesville, Fla.

G. Carta. University of Virginia, Charbottesville, Va.

C. H. Byers. Oak Riodge National Laboratory, Oak Ridge, Tenn.

"Available from the National Technical Information Service, U.S. Department of Commerce, 5285 Port Royal Road, Springfield, Virginia 22151. 


\section{SENSORS FOR ELECTROLYTIC CELLS}

1080 Temperature Measurement by Observation of the Raman Spectrum of Dlamond Appl. Spectrosc. 46, pp. 375-77 (1992)

S. Dai, J. P. Young, G. M. Begun. Oak Ridge National Laboratory, Oak Ridge, Tenn. G. Mamantov. University of Tennessee, Knoxville, Tenn.

1081 Measurement of Radical Cation UV-VIsible Spectrum in a Polycrystalline Freon Matrix at Liquid Nitrogen Temperature by Diffuse Reflectance Spectroscopy Appl. Spectrosc. 46, pp. 377-78 (1992)

S. Dai, J. P. Young. Oak Ridge National Laboratory, Oak Ridge, Tenn.

G. Mamantov, J. T. Wang, F. Williams. University of Tennessee, Knoxville, Tenn.

1082 A Now Sample Cell for Diffuse Reflectance IR Spectroscopy of Alr-Sensitive Solld Samples

Appl. Spectrosc. 45, pp. 1056-58 (1991)

S. Dai, J. P. Young. Oak Ridge National Laboratory, Oak Ridge, Tenn.

G. Mamantov. University of Tennessee, Knoxville, Tenn. 


\section{HYDROPOWER ENVIRONMENTAL MITIGATION}

1083 Use of a Reservolr Water Quallty Model to Simulate Global Climate Change Effects on Fish Habltat

Clim. Change 20, pp. 277-96 (1992)

L. H. Chang, S. F. Railsback. Oak Ridge National Laboratory, Oak Ridge, Tenn.

R. T. Brown. Jones \& Stokes Assoc., Sacramento, Calif.

1084 Environmental Mitigation at Hydroelectrlc Prolects. Volume 1. Current Practices for Instream Flow Needs, Dissolved Oxygen, and Fish Passage DOE/IE-10360* (December 1991)

M. J. Sale, G. F. Cada, L. H. Chang, S. W. Christensen, S. F. Railsback. Oak Ridge National Laboratory, Oak Ridge, Tenn.

J. E. Francfort, B. N. Rinehart, G. L. Sommers. Idaho National Engineering Laboratory, Idaho Falls, Idaho

1085 A New Look at Environmental Mitigation Practices

Hydro Review, pp. 58-66 (July 1991)

M. J. Sale, S. F. Railsback. Oak Ridge National Laboratory, Oak Ridge, Tenn.

1086 Environmental Impacts of Increased Hydroelectric Development at Existing Dams ORNLTM-11673 (April 1991)

S. F. Railsback, G. F. Cada, C. H. Petrich, M. J. Sale, J. A. Shaakir-Ali, J. A. Watts, J. W. Webb. Oak Ridge National Laboratory, Oak Ridge, Tenn.

1087 Revlew of Mitigation Methods for Fish Passage, Instream Flows, and Water Quality Waterpower '91, Proceodings of the International Conference on Hydropower, Denver, Colorado, July 24-26, 1991, ed. D. D. Darling, 1, pp. 209-18 (New York: American Society of Civil Engineers, 1991)

S. F. Railsback, G. F. Cada, L. H. Chang, M. J. Sale. Oak Ridge National Laboratory, Oak Ridge, Tenn.

1088 Effects of Hydroelectric Turbine Passage on Fish Early Life Stages Waterpower '91, Proceedings of the International Conference on Hydropower, Denver, Colorado, July 24-26, 1991, ed. D. D. Darling, pp. 318-26 (New York: American Society of Civil Engineers, 1991)

G. F. Cada. Oak Ridge National Laboratory, Oak Ridge, Tenn.

1089 Distribution and Stabllity of Potentlal Salmonid Spawning Gravels in Steep

Boulder-Bed Streams of the Eastern Slerra Nevada

Transactions of the American Fisheries Society 120(2), pp. 177-86 (1991)

G. M. Kondolf, G. F. Cada, M. J. Saie. Oak Ridge National Laboratory, Oak Ridge, Tenn.

T. Felando. INYO National Forest, Bishop, Calif.

1090 Improving the Assessment of Instream Flow Needs for Fish Populations

Waterpower '91. Proceedings of the International Conference on Hydropower, Denver, Colorado, July 24-26, 1991, ed. D. D. Darling, 1, pp. 76-84 (New York: American Society of Civil Engineers, 1991)

M. J. Sale. Oak Ridge National Laboratory, Oak Ridge, Tenn.

R. G. Otto. R. G. Otto \& Associates, Arlington, Va.

\footnotetext{
- Available from the National Technical Information Service, U.S. Department of Commerce, 5285
} Port Royal Road, Springfield, Virginia 22161. 
1091 A Review of Studles Relating to the Effects of Propeller-Type Turbine Passage on Fish Early Life Stages

North American Journal of Fisheries Management 10, pp. 418-26 (1990)

G. F. Cada. Oak Ridge National Laboratory, Oak Ridge, Tenn. 


\title{
ENVIRONMENTAL CONTROL TECHNOLOGY
}

\author{
1092 Alternative Non-CFC Moblle Air Conditioning \\ ORNL/CON-335 (September 1992) \\ V. C. Mei, F. C. Chen, D. M. Kyle. Oak Ridge National Laboratory, Oak Ridge, Tenn.
}




\section{CONTINUOUS FIBER CERAMIC COMPOSITE TECHNOLOGY}

1093 The Relative Residual Fiber Displacement After Indentation Loading and Unloading of Flber-Reinforced Ceramic Composites J. Mater. Sci. 28(8), pp. 2227-32 (April 15, 1993)

C. H. Hsueh, M. K. Ferber, A. A. Wereszczak. Oak Ridge National Laboratory, Oak Ridge, Tenn. 


\section{AUTHOR INDEX}

\section{A}

Abata, D. L.

540,554

Ackerman, J. L. .....................................448

Ackermann, R. A. .. 161, 162, 176, 177, 185

Adams, M. B. ........................................ 972

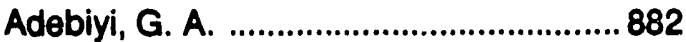

Adibi, M. M. ................................. 744, 753

Adler, H. I. .............................................. 1058

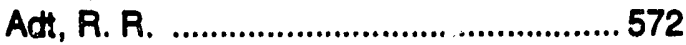

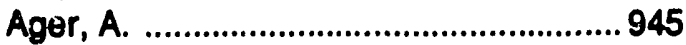

Ahman, J. ................................................ 374

Alam, M. S. .............................................. 122

Aldrich, T. E. ........................................... 816

Alexander, D. J. ........................................65 655

Alexander, K. B. ............ 830, 843, 850, 851

Alexander, R. R. .................................902

Allard, L. F. ............................................ 419

Ally, M. R. ....... 599-604, 606-609, 611-12

Amin, K. E. ............................................444

Amirkhanian, K. R. .................................280

Anderson, I. C. ......................................... 893

Anderson, R. W. ...................................... 198

Anderson-Batiste, G. J. ........................ 54

Angelini, $P$.

Anliker, K. S.

$431,465,489,500$

Apsley, D. K. ............................................ 899

Arendt, R. H. ......................................... 828

Arimilli, R. V ................................ 867, 878

Arnott, J. T. ............................................. 913

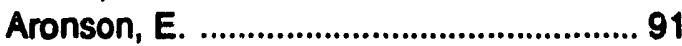

Aseltine, M. ..................................... 98, 284

Ashby, W. C. ......................... 897, 903, 922

Auld, D. L. ........... 904, 905, 965, 981, 1018

Awa, V. S.

481

\section{B}

Bair, R. E. .578

Bajer, E. R.

339

Baipai, $R$. 1059

Baker, Q. A. 565,571

Bakdoni, J. G. . 378, 426, 442, 469, 484, 509

Bales, E. 247,255

Barbieri, A. 646

Barito, M. O.

220

Barito, R. W.

.220

Barnes, M. H. 286
Barnes, P. R. $742,747,748$, $758,760,762,763,769$, $772,779,780,782,789,797,798$

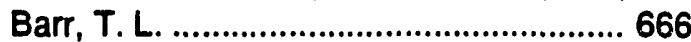

Bates, C. H. ......................................... 453

Bates, J. B. ............................................. 491

Baugh, R. N. ........................................... 180

Baxter, V. D. ......................................... 134

Bayer, R. G. .............................................. 717

Beachley, N. ............................................ 884

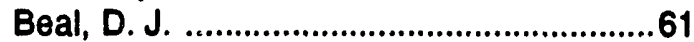

Beale, W. T. ................................... 151, 152

Becher, P.F. ...................... 419, 431, 435, $465,489,493,500$, $504,510-12,523,693,694$

Bechtold, R. L. ........................ 566-68, 581

Beck, J. V. ............................................. 249

Bednarczyk, P. J. .................................... 828

Beecher, D. T. ...................................... 188

Begovich, J. M. ...........................1071, 1077

Begun, G. M. ............. 412, 456, 467, 1080

Behi, M. ..................................... 353, 367

Bennett, A. I. ............................................ 749

Bennett, M. N. ........................................... 100

Bennett, M. R. ........................................ 881

Bentley, J. ................................................ 858

Berchowitz, D. M. ..................................116

Berens, A. P. .............................. 409, 413

Bergman, L. B. ............................. 757, 770

Bergoust, D. G. .................................... 339

Berry, L. G. ...........................37, 50, 56, 290,

$291,299,344,731,735$

Beschen, D. A., Jr. ................293, 295, 298

Besmann, T. M. ..... 637, 639, 675, 685, 837

Beyer, M. A. ............................................. 295

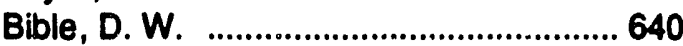

Bishop, P. S. ................................ 622, 662

Blake, T. J. ............ 983, 984, 986, 987, 989

Blakely, K. A. ......................................... 632

Blalock, T. V. ........................................... 766

Blanchard, J. P. ..................................... 808

Blanco, J. A. ................................. 545, 572

Blankenhorn, P. R. ..................... 954, 960,

$1000,1019,1020$

Blass, J. J. .............................................620

Blau, P. J. .............364, 399, 699, 701-703, $705,707-11,714-16,720,724$

Bledsoe, J. L. ................................... 276, 344

Bleier, A. ..................................... 615, 641 
Blum, J. B. 470

Boercker, F. D. ...................................... 330

Boggs, D. L. ...........................................5 578

Bomar, E. S. ......................................... 623

Bond, W. D. ............................................5 500

Bongarten, B. C. ..................... 899, 916, 975

Bonk, J. J. ............................................... 750

Booker, B. L. P. ........................................ 460

Booker, M. K. ....................................... 486

Boring, L. R. ...........................................916

Borman, G. L. .........................................5 578

Boulet, J. A. M. ...................... 376, 383, 485

Bowersox, T. W. ................... 954, 960, 964, $1000,1019,1020$

Bowles, J. P. 812

Bradley, S. $379,441,476,482$

Bradshaw, H. D., Jr. 890

Bradt, R. C. 514,515

Bransby, D. I. Braun, A. T.

Braunstein, J.

Bresnan, D. F.

Breve, M. A.

Bridges, D. C.

Bright, J. D.

Brinkman, C. P.

$941,968,980$

610,881

897,903

926,943

904

473,518

Broach, R. W. $412,424,456$, $462,467,480,522$

Broadaway, E. R.

666

Broadwater, R. P 784

Brontman, B. H. 773,786

Bross, J. M. 15

Brown, J. J. 339

Brown, M. A. . 14, 27, 30, 32, 40, 44, 46, 53, $63,65,68,72,79,80,81,83,95$ $99,291,293-96,298,299,322,729-38$ Brown, R. H. Brown, R. T. Brynestad, J. Bryson, J. W., Jr. Buckels, L. S. Budai, J. D. Buljan, S.-T. $660,661,836$ $378,426,442$ $469,484,506,508,509$

Burgess, D. 948 Burghardt, R. R. 749

Burns, $R$. 309

Burrage, L. M.

Busche, R. M.

Busching, H. W. $1,806,814$ 1055,1056

Butler, J. L. 278,280

Buxton, D. R.
Buzza, T. G 575 Byerly, R. T.

Byers, C. H. 768 1069-79

Cada, G. F. .......1084, 1086, 1087-89, 1091

Cagle, S. L. ...............................................94

Callahan, T. J. ................................559, 569

Calvin, M. .................................................. 993

Canright, G. S. ....................................... 821

Cantor, R. A. ..................................67, 906

Caponetti, E. C. ..............590, 591, 594, 596

Caputo, A. ............................................ 261

Carduner, K. R. ..................................... 525

Carim, A. H. ............................................ 829

Carlsmith, R. S. .......................................43

Carison, J. D. ............................................... 202

Carison, M. .............................................. 945

Carmody, J. .............................204, 211, 267

Carpenter, H. W. .................................. 472

Cappenter, J. A., Jr. ........................666, 692

Carroll, W. L. .................................282, 283

Carta, G. 1069,1070

$1072,1073,1075,1079$

Cater, D. G. ........................................... 339

Carter, R. O., III ....................................... 525

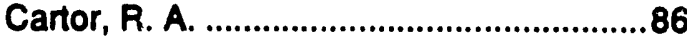

Cates, M. R. ............................................ 542

Cathcart, J. V. .......................................682 682

Cavin, O. B. .......... 456, 467, 642, 834, 854

Cawley, J. ............................................. 374

Ceder, G. ............................................... 659

Ceulemans, R. ...............................978, 1013

Chakoumakos, B. C. ................................ 838

Chandier, W. U. ........................................... 43

Chandra, D. ............................................. 877

Chandrasekaran, A. ......................773, 786

Chang, C. L. ..................................373, 443

Chang, L. H. ................... 1083, 1084, 1087

Chen, C. F.

526

Chen, F. C. ...................101, 113, 123, 139,

$142,155,166,184,189,1092$

Chen, G. L. ..............140, 142, 145, 150-52

Cheng, W. K. ........................................5 541

Cherney, J. H. .............................939, 1003

Chevacharoenkul, S. ............................. S06

Chia, K. ................................................ 370

Childs, K. W. . 208, 220, 230, 265, 266, 272

Childs, P. W. ..................195, 201, 231, 251

Choi, S.-I. 
Choudhury, A. 658,857

Christen, D. K. $660,661,827,836$

Christensen, S. W. $838,839,841,844,848,852$

Christian, J. E. $192,196,200,202,203$ $210-12,214-18,226,248,254,273,276$ Christopherson, N. S. 946

Chu, W. 220

Chuang, T.J. 526

Chuck, $L$. 361,423

Civale, L. $825,838,841,846-48$

Clark, A., III 1039

Clausing, R. E. 705

Clem, J. R. 847

Clemans, C. L. ...................................... 740

Clements, K. A. ................................ 744

Clinch, J. M. 185

Coady, S. A. 902,912

Coghlan, W. A. .857

Cole, D. W. 1012,1021

Cole, G. V. .902

Coleman, P. R. 1048

Colietti, J.P. 907,908

Collier, R. K., Jr. 101

Comfort, A. M 428

Compere, A. L. .. 531, 588-90, 592-95, 597 Conklin, J. C. $107,117-20,128$ Consumer Energy Council of America

Research Foundation .97

Cookson, A. H. 749

Cooley, K. C. 637

Corbin, N. D. .. 354, 373, 422, 443, 471, 483

Cordaro, J. F. 774,785

Courville, G. E. ..... 195, 212, 215, 223, 230, $231,237,238,240,246,249,250,251,278$

Cowles, J.R. 1022

Cranmer, D. C. 357

Creswick, F. A. $149,158,165$

Cropper, W. P., Jr. 1041

Crosbie, G. M. $410,420,463,525$

Crosswhite, R. N. 137

Crow, T. R.

Cuccio, J.S. 952,1017

Cundiff, J.S. 356,428

Cunningham, $M$. $921,942,974$ Curtin, D. T. 1004,1023

Cushman, J. H. ..... 887, 889, 892, 909, 917, Cutler, R. A. $923,933,951,953,971,999,1024$ 473,518
D'Angelo, C. 381,445

Daby, E. E. 557,561

Dai, $S$. 1080-82

Dale, S. J.

Dale, V. H. .1044 Daniels, W. L. .......................921, 942, 973

Darley, J. M.

Das, $\mathbf{S}$. 390,625

David, S. A.

Davis, G. D.

Davis, R. F.

Davis, S. C.

Davis, T. D.

Davison, B. H. $653,746,787,796$ $468,638,674,678$

$403,404,436,506$ $4,24,54,68$ .... 947

1056-59, 1061, 1063

Daw, C. S. .............................................. 532

de Fontaine, D. ...................................... 659

DeAngelis, D. L. ................................... 972

DeBell, D. S. .............979, 1008, 1026, 1033

DeCarli, J. P. ................................ 1073-75

DeCarti, J.P., II ........................... 1069, 1070

DeGrush, D. 175

Delmas, A. A. ........................................ 197

DeLuca, J. A. .......................................... 828

Denny, J. C. 573,579

Deonigi, D. E.

Desjarlais, A. $O$.

DeVan, J. H.

DeVault, R. C.

DeVore, C. E.

$92,195,222,260$

$.598,605,680$

$124,136,141$ $702,707,710$,

$711,719,724,728$

Dhere, A. G. 854

Diamond, R. C.

Dickey, D. W.

Dickmann, D. I.

304,329

Dickson, R. E.

DiCola, M. L. 569

Didion, D. A.

Diemond, C. C.

Diendorter, $\mathbf{G}$.

Dillard, D. M.

Dimmel, D. R.

1009

Dimplefeld, P. M. .................................... 578

Dinan, T. M. .................................................84

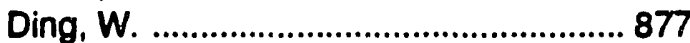

Dinus, R. J. .......................................... 938

Dippon, D. R. ...............................996, 1049

DiStefano, J. R. $622,662,680$ 
Dixon, R. K. 1034

Dobbins, C. L. 935

Domanski, P. A 181

Domingo, $N$.

Doshi, D.

$528,542,543$

Dougall, D. K

368

Doverspike, $K$

Downing, D. J.

Doyle, T. W. 335

Dragoo, A. L.

953,967

Drake, J. B.

Dresner, L.

Dreysse, $\mathrm{H}$.

Dripchak, K.

Dubbe, D. R.

439

871

826,842

659

995

990,1002

Dufrane, K. F. $385,418,446,488,513,524$

Dugan, R. C

$794,807,814$

Dunlap, J. D.

898

Dunlap, J. M.

978

Dunn, E. M.

452

Dvorchak, $M$.

278

\section{E}

Eades, R. A. 666

Easterly, C. E. ....... 776, 800, 804, 816, 818

Easton, D. S. 821

Eaton, R. A.

812

Eden, A.

338

Ehrenshatt, A. R.

887,911 ,

$937,969,970,992$

Eichler, C. H. ...........................................782

Eilts, L. E. ..................................................740

Eisenberg, J. F. ...................................... 294

Eisenhaure, D. B. .................................. 884

Elkassabgi, Y. ..................................... 126

Ellingson, W. A. ........................... 365, 448

Ellis, D. D. .............................................. 997

Elmore, J. L. .............................................. 982

English, B. C. ...........................................902

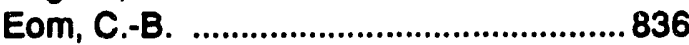

Erickson, D. A. ............................ 904, 905

Erwin, J. ................................. 548, 558, 574

Eto, J. .42

Evans, D. M. .......................................... 230

Everleigh, C. A. ........................................640 640

Ewel, K. C.
$\mathbf{F}$

Fagan, T. J. 188

Fairchild, P. D.

Fang, $H$. T.

$102,111,143$

Faulkner, J. S $356, .482$

Fear, M. P. 673

Federer, J. I. 416,457

Feenstra, R.

Feero, W. E.

Feild, C. A.

Feirer, R. P.

Felando, $T$.

Felker, $P$.

$.613,616,617$
$1,624,626-30$

$619,621,624,626-30$

$.739,768$

$.846,848$

938

Fenn, R. C.

1089

Ferber, M. K

$1016,1032,1036,1037$

$425,427,474,510,511,521,1093$

Ferguson, P. A.

647

Fick, G. W.

936

Figliole, A.

978

Fine, H. A. .... 156, 208, 213, 219, 220, 689

Fischer, A. T.

$.687,858$

Fischer, S. K. $102,104,105,108$, $110,111,132,133,149,158,159,165$

Fisher, J. T. 977

Fiskum, R. J. ............................................ 122

Fitzpatrick, G. L. ..........................................15

Flanigan, C. T. .......................................... 549

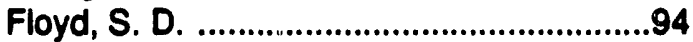

Foley, M. R. ...................................354, 380

Folger, A. G. ......................................1025

Fort, E. M. ............................................. 749

Fortson, N. H. ...................................... 777

Foster, B. E. ................................456, 467

Foster, D. E. .................................578, 585

Foust, J. V. .......................................... 766

Franctort, J. E. ....................................1084

Franchuk, C. A. .................................... 730

Frank, J. C. .............................................. 233

Fraser, J. ............................................... 392

Frazer, J. W. .........................................66 666

Frederick, D. J. .............................1006, 1039

Freeman, E. ............................................ 290

Freeman, E. C. .......................................339

Freeman, L. .......................................... 322

Friggle, W. .............................................. 738

Fulkerson, W. ...................................... 143

Fuller, L. C. ....................................336, 680 
G

Gadoth, D. 115

Gallois, B. M. 639

Gao, F. 541

Gao, J. 359

Garbauskas, M. F. .................................. 828

Gardner, R. H.

Garg, A. K. 1048

Garver, E. G.

Garwin, I. J.

Gaydos, P. A.

Gazza, G. E.

Goballe, T. H.

Geller, E. W.

George, E. P.

Gettings, M. B.

Geyer, W. A.

Gillette, G.

Ginatempo, B.

Glaeser, W. A.

Glavincevski, B.

Glicksman, L. R.

Glumac, E. L.

Gnadt, P. A.

Godia, F.

Goel, R. K.

Goeltz, R. T.

Goewey, P.

Goins, L. F.

Goldberg, L. F.

Goldman, C.

Gornmed, K.

Gonalez, J. M.

Gonos, J.

Goodman, W. R.

Goodrich, S. M.

Goodwin, G. M.

Googin, J. M.

Goyal, A.

Grado, S. C.

Granryd, E.

Grant, D.

... 354

990,1002

557,561

$385,418,446$

517

836

139

$642,654,656$

$22,287,289$,

$297,300,320,330,332$

$1010,1030,1038$

.88

646

$488,513,524$

$235,243,258$

1036, 1037

771,812

1058

$27,731,735$

89,93

Graves, G. A

Graves, R. L.

313

229

308

$33,59,60$

115

614

322

902,912

$361,409,413,423$

638

595

$823,830,835$

$954,960,1000,1020$

118,128

409,413

409,413

$412,456,467,537$,

$543,549,564,577,582,587$

Graves, R. S. ......... 199, 207-209, 212-15, $224,225,227,241,244$,

$245,279,433,477,491,505$

Greene, D. K.

939

Greene, D. L.

71

Greer, M. E. 873

Grittin, F.P.

154

Grittin, G. D. .......... 776, 800, 803, 804, 818

Griffith, W.

180

Griffith, W. L. ..... 531, 588-90, 592-95, 597

Griggs, E. I. .......................234, 240, 268

Groeger, J. H. ........................................ 796

Grossman, G. ....................................... 115

Grossnickle, S. C. .................................. 913

Grz, 2iwski, S. ......................................... 763

Gunther, E. W. ....................................... 822

Gutraj, J. M. .................................. 160, 179

Gyorffy, B. L. ................................ 646, 659

\section{H}

Habenschuss, A. ......................... 721, 723

Habert, J. S. .............................................. 338

Hackner, R. J. .......................................... 163

Hahn, J. M.

Haissig, B. E.

813

976, 1001, 1035, 1052

Hall, J. A. 317,324

Hall, R. B. $891,907,908$

Hallett, $F$.

$914,915,919,920,948$

687,858

Hamby, C. .............................................. 644

Hamitton, R. M. ........................................ 813

Hammarstrom, J. L. ....................... 373, 443

Hammond, J. P. ....................................... 468

Hamrick, J. L. .......................................... 975

Han, B. J. ............................................... 264

Hanna, R. D. .................891, 914, 915, 920

Hansen, E. A. 894, 1014, 1015, 1045, 1051

Hansen, J. J. ............................................. 473

Hansen, J. S. .........................373, 422, 443

Hansen, P. H. .......................................1034

Hanusiak, W. M. ....................................... 498

Harry, D. E. ...........................................966

Hart, E. R. ............ 891, 914, 915, 919, 920

Hartford, E. H. ....................................... 836

Hartline, S. D. ....................................... 444

Haselkom, M. H. ............363, 387, 417, 447

Hauser, D. ......................................... 374

Hausner, H. .......................................... 439

Havstad, P. H. ............................... 557, 561

Hawkins, D. R. ....................................... 993

Hawsey, R. A. ............................... 824, 831

Hayes, F. C. ........................................ 103

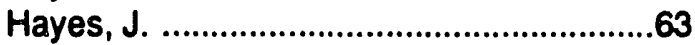


Haynes, H. D.

Heatherly, L. J.

Hebner, R. E. 766

Hecht, N. L. $361,409,413,423,520$

Hefter, J. 378

Heichel, D. W. 517

Heilman, P. E.

Hellman, E. S.

$890,898,949,978,1007$

Henson, H. M.

Henson, T. J.

Herms, D. A.

Hettwer, P. F.

Heuchelin, S. A.

Hewett, M. J.

Hewitt, D. C.

Heyer, S. V.

Hicks, E. G.

Hicks, K. L.

Hill, D. H.

Hill, L. J.

Hillis, S. L. $527,529,533,534$ $551,552,556,560,563,570,580$

Hilton, $\mathbf{S}$ 409,413

Hinckley, T. M.

$890,978,1027$

Hindman, D. L.

Hine, $T$.

Hirschteld, D. A.

474,521

Hirst, E. (20, 22, 23, 25, 26, 28, 29, 31-36, 39, $41,42,45,47-49,51,52,56,58-60$, $62,64,66,69,74-78,87,90,91,93$

Ho, C. M. 139 Hobson, D. O. 677 Hockey, B. J. Hodgson, J. W. 402,426 527,529 $546,551-53,573,579$

Hoenigman, J. R 409,413 Hotfman, M. G.

Holcomb, M. C. 15

Holcombe, C. E. .. 94

Holloway, D. L. 644

Holmes, J.

Holmes, J. M.

Holtzberg, F.

Hook, D. D.

Hopper, A. T. Hornbeck, J. W. Horowitz, S. H. Horton, J. A.

Horton, L. L. 365 339 1071,1076 $825,841,844-48$ 1033 374 1012,1021 767,815 ..... 642, 648, 657, 665, $669,670,671,678,682$

Host, G. E. 396 950,952
Hough, R. E. 309

Houska, C. R

$721-23$

Howard, A. J.

1072,1079

Howell, M. 598

Howells, E.

Hsu, H. 829,

Hsu, S. M.

Hsueh, C. H.

Hu, P.S. 814 834 439 $465,489,1093$ $19,21,24,38,54$ $57,61,70,92,96,313,325,327$

Huang, B. Y. 652

Huang, Y.J. 267

Hubbard, C. R. ....... 832, 833, 834, 840, 850

Hubbard, M. S. ..................................... 292

Huber, D. A. ........................................... 899

Huckabee, M. L. .... 378, 442, 484, 506, 509

Hudson, T. L. ....................................... 780

Huetteman, C. A. ...................897, 903, 922

Hughes, P. J. ........ 102, 106, 111, 112, 163

Hunsaker, D. B., Jr. ................................ 982

Hunter, C. E. ...................................557, 561

Huntley, W. R. ...................................... 239

Hwang, B.-H. .......................... 721-23, 725

Hwang, H. L. 303

I

Ice, G. E.

$.721,723$

Ildstad, E. 796

Isebrands, J. G. $910,952,958$, $978,1009,1013,1034$

\section{J}

Jackins, G. A., Jr. .................................. 339

Jackson, W. L. .......................................... 159

Jang, S. D. .....................................413, 520

Janney, M. A. ......................401, 498, 505,

$623,631,632,643$

Janssen, J. E.

Jenkins, M. G.

$346,356,358$

$398,425,514,515$

Jenkins, $V$. T 398

Johnson, C. A

$360,449,519$

Johnson, D. D. 646,651

Johnson, D. R. .......389, 400, 406, 411, 438, $439,458,466,487,492,498,499,503$ Johnson, D. W. $927,1011,1012$ $1021,1042,1044$

Johnson, J. 805

Johnson, J. S., Jr. ...........589, 590, 594, 596 Johnson, K. D. $.939,1003$ 
Johnson, K. H. ....................................... 916

Johnson, M. A. ........................................ 938

Johnson, W. D. ....................................... 990

Johnson, W. S. .................................... 180

Johnson-Mohler, E. ........................ 98, 284

Johnston, C. A. ....................................... 991

Johnston, J. W. ...................... 933, 971, 999

Johnston, J. W., Jr. ..................... 940, 1024

Jones, D. W.

Jones, E. C.

Jordan, A. C.

Joslin, D. L.

Jou, W. H.

Joyce, T. W.

Joyner, P. A.

Judkoff, $R$.

1043

$660,661,827$

631,692

432,461

139

592

110

304

\section{$\mathbf{K}$}

Kafka, R. J. 744

Kahl, W. K. .... 412, 456, 467, 532, 550, 587

Kalish, Y.

Kang, S.

386

Kannberg, L. D.

$395,414,452$

Kao, M. Y. 866

Karas, P. L.

Karasek, K.

Kardas, A.

Karnitz, M. A. ............. 154, 286, 317

$324,328,329,342,345$

Kauffield, $M$ 135

Kean, J. N.

Keating, $\mathrm{K}$.

Kedl, R. J.

Kee, D. D.

15

Keiser, J. R.

Kelkar, A. D.

Kelley, E. F.

Kelley, F. A.

Kelly, J.M.

Kempton, W.

Kennedy, W. N.

Kenney, W. A.

Kerchner, H. R.

Kertesz, M. P.

Keshock, E. G.

Ketcham, T. D.

Keyes, B. L. P.

Khandelwal, P. K.

Kidd, G. H.
Kiggans, J. O. ............................................ 643

Kim, C. ............................................... 585

Kim, H. E. ................................................ 616

Kim, H. J. ................................... 381, 414

Kim, K. .................................................. 414

Kim, K. S. ............................................. 452

Kim, N. ............................................. 263

Kimrey, H. D. ................................................ 643

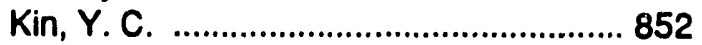

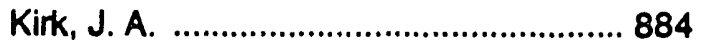

Kirk, M. A. .............................. 825, 846-48

Kirkpatrick, J. R. .................................... 257

Kirmse, R. D. ......................................... 977

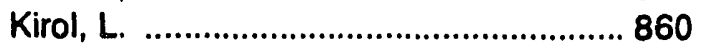

Klabunde, C.E. ..................................... 827

Kladivko, E. J. .......................................... 939

Klareich, F. H. ........................................ 233

Klass, S. ............................................... 1032

Klatt, L. N. .................................. 603,604

Klein, K. W. ................................ 746, 787

Klemens, P. G. ..................................... 263

Klopienstein, N. B. ................................. 920

Knapp, C. E. ........................................ 470

Knoke, G. S. ............................................. 139

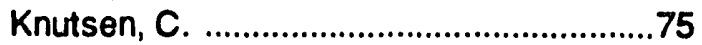

Kobayashi, A. S. ........................... 514, 515

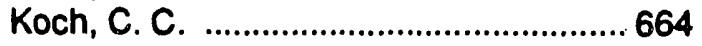

Kodas, T. T. ................................................ 829

Koehler, W. C., Jr. ................................. 295

Koester, D. A. ........................403, 404, 436

Kolb, J. O. ............. 292, 300, 304, 318, 334

Kollie, T. G. ...................193, 208, 220, 228

Kondolf, G. M. .........................................1089

Kopp, R. F. ......................................1010

Kornhauser, A. A. ................................... 182

Kons, R. A. ............................................. 981

Krahn, L. ............................................. 262

Krarti, M. ................................................. 230

Krause, F. ...................................... 59, 60

Krause, R. ........................................... 357

Kroeger, D. M. .................... 821, 823, 829,

$830,834,835,843,850-58$

Krummel, J. R. ................. 1029, 1043, 1048

Kruse, V. J. ...........................750, 760, 762

Krusin-Elbaum, L. ...........825, 841, 846, 847

Kuman, K. ........................................... 230

Kurka, K. ..............................776, 804, 818

Kweller, E. .............................................. 123

Kyle, D. M. ................................... 192, 1092

Kyriacou, C. I. ........................................... 388 
$\mathbf{L}$

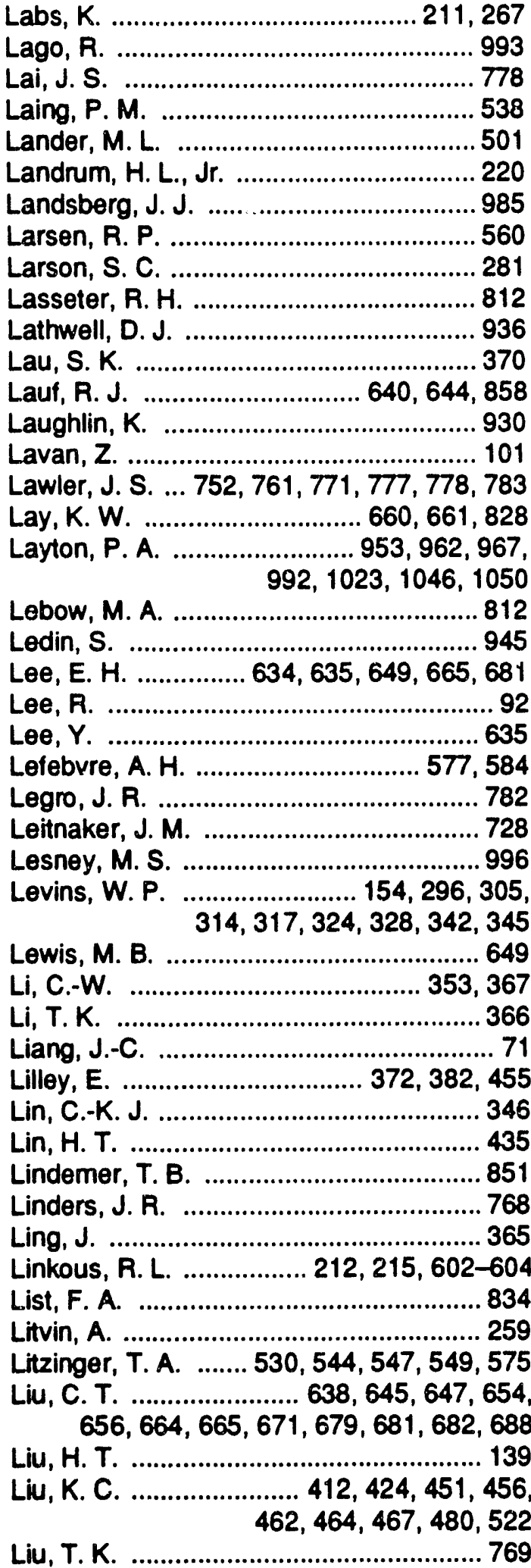

Liu, W. ...................................................... 426

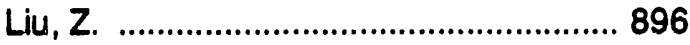

Lizzio, A. ................................................ 590

Loewen, K. H. ......................................... 902

Long, C. E. ...............................................1038

Long, E. L., Jr. ...................................... 587

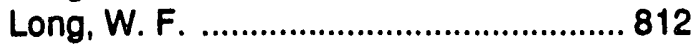

Longmire, C. L. ....................................... 813

Lothner, D. C. ............................................ 963

Love, P. M. ....................................229, 246

Lovett, W. R. .......................................1010

Low, J. J. ............................................... 666

Lowden, R. A. ........................................ 637

Lowenberg-DeBoer, J. ......................... 935

Lowndes, D. H. ...............660, 661, 827, 836

Loxton, C. M. ........................................ 657

Lstiburek, J. ............................................ 204

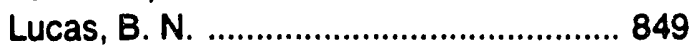

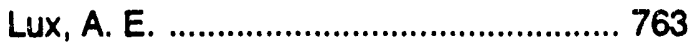

Luxmoore, R. J. ..................................... 972

Lyle, F. F., Jr. ....................................... 555

Lynd, L. R. ......................... 917, 951, 1056

\section{M}

MacDonald, J. M. ................106, 234, 287, $289,304,307,316,320,323$, $326,329,335,338,339,340,765$

Macey, S. M.

Macriss, R. A.

$144,160,179$

Maguire, M. C. ........................................674 674

Mahler, K. A. ................904, 905, 965, 1018

Major, C. H. ............................................. 46

Major, J. E. ........................................... 913

Major, R. W. ...............................757, 770

Majumdar, B. S. ...............................374, 454

Malcolm, E. W. .................................... 938

Malozemoff, A. P. ...........841, 844, 846, 848

Mamantov, G. ...............................1080-82

Mangels, J. ........................................... 371

Mann, L. K. ............................................1021

Mansur, L. K. ..................................635, 649

Manwiller, K. E. ...................................... 470

Marans, R. W. ..............................................

Mariand, G. ......................................... 944

Marsh, G. C. ........................................... 851

Martin, C. W. ......................................1021

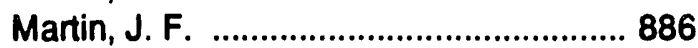

Martin, M. .......................................... 516

Martin, R. L. .................................398, 425

Manwick, A. D. $825,838,841,844,847,848$ 
Mashikian, M. S. ..................................... 796

Mason, T. W. ........................................... 86

Masterson, D. .......................................554

Mathiprakasam, B. ......................... 155, 184

Matijasevic, V. C. ...................................... 836

Mattson, J. A. ........................................... 946

Maybee, C. ........................................... 936

Maziasz, P. J. .........................................638 638

Mazzucchi, R. P. ..................................... 304

McBrayer, J. F. ....................................... 982

McBride, M. F. ....................................... 216

McCamy, J. W. ....................................... 661

McCarthy, J. F. .......................................99 918

McCauley, J. W. ................................... 439

McClung, R. W. ..... 478, 492, 498, 663, 691

McClure, P. K. ........................................ 339

McCluskey, P. H. .................................. 433

McCold, L. N. ............... 330, 332, 333, 343

McConnell, B. W. .......... 747, 751, 806, 808

McCool, J. I. ................................. 706, 718

McCorkle, J. ............................................ 278

McCown, B. H. ............................. 976, 997

McCoy, H. E., Jr. .................................. 756

McCulium, D. E. ..... 361, 409, 4'3, 423, 520

McElifresh, M. W. .................................. 848

McElroy, D. L. ....................... C07-209, 212,

$213,215,219-21,224,225$,

$228,244,254,279,491,650$

McEntee, J.

140

McEvers, J. A.

619

McFarland, $M$.

104

McGill, R. N.

$527,529,533$

$534,536,546,551,552,556$,

$560,563,570,573,580,582$

McGranaghan, M. F.

807,822

McGraw, B. A.

180

McHargue, C. J. ..... 396, 397, 461, 494, 495

Mclver, J. C.

812

McKamey, C. G.

670,821

McKenna, J. R. 973

McLain, H. A.

$106,276,306,335$

McLaughlin, R. A. 1014,1045

McLaughlin, S. B. 887

McLinden, $M$. 135

McMahon, B. G. 891

McMahon, J. E. 43

McMurtry, C. H.

347

McNabb, H. E., Jr.

McNabb, H. S., Jr.

McNabb, W. A.

.959

McNatt, J. D.

$891,919,920,998$ $887,992,1023$

McRoberts, R. E. 1034
Mdafri, A. 935

Meckler, G. 101

Medelius, $\mathbf{P}$

Mei, V. C. $788,793,805$ $101,113,121,123$, $134,142,153,155,164$, $169,174,184,186,1092$

Melichar, L. 1038

Melton, B. S. 272

Mertol, A. 282,283

Meskimen, G. F. 1031

Miami, University of 586

Michael, D. A. $952,958,1009$

Michaois, $\mathrm{H}$. $\ldots 15$

Nichels, E. 294

Michler, C. H. .1001

Mihlmester, P. E. 295,322

Mikijeli, B. 371

Milberg, M. E. 525

Miller, C. W., Jr. 368,393

Miller, D. B. 741,763

Miller, J. H. 637

Miller, R. G. ........................................ 209

Miller, W. A. ... 146, 148, 154, 168, 172, 187

Minton, N. A. ...................................... 943

Misuriello, H. ............................................ 321

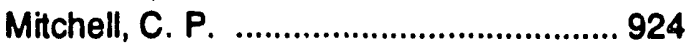

Mitchell, W. 530

Mixon, W. R.

Miyasaka, S. C.

$304,321,329$

Mize, C. 1026

Mizuhara, H. .......................................... 452

Modahl, R. J. ........................................... 103

Modine, F. A. ..................... 757, 759, 770,

$774,785,790,817$

Monteen, L. D. ........................................ 778

Moodera, J. S. .......................................... 828

Moore, N. L. ..........................................44

Moorhead, A. J. ..... 616, 686, 693, 694, 695

More, K. L.

Morel, T.

$403-405,436$

Morgan, S. J. 375,496

Morrell, J. A.

Morris, L. E.

Morris, M. D.

Morris, M. D.

Motakef, S.

Moy, C. A.

Mukherjee, A. K.

.73

738

Mulroney, P.

Mulroy, W. 692

Murphy, R. W.

Murray, M. D. 
Mutsuddy, B. C.

\section{$\mathbf{N}$}

Nadel, $\mathbf{S}$. 15

Natansohn, S. 348,421

National Planning Committee for District

Heating, Cooling and Cogeneration ... 285

Naus, D. J. 286

Naylor, M. G. S. $352,362,416,457$

Netf, H. P., Jr. 775

Nehmadi, $M$. 766

Neil, J. T. $378,442,469,484$

Nelson, G. D. 308

Nelson, J. K. 814

Nelson, N. D. $958,1009,1035$

Nelson, W. R.

Nemethy, E. K. 783,784

Newson, D.

Nguyen, P. V. 353,367

Nichol, J.

Nichols, R. J. 917,951

Nicholson, D. M. ....636, 646, 651, 659, 673

Nicholson, J. M. ..................... 410, 420, 463

Nickel, D. L.

Nieh, T. G. 750

Nixon, $R$. 688

Noble, M. T. .506

Nolan, M. G.

Norby, R. J.

Nordh, N. E.

Norton, D. P.

Noun, R. J.

927,928

945

$660,661,827,836$

.44

O'Hern, M. E. 849

O'Leary, L. 333

O'Neal, G. G.

O'Neill, R. V.

565,571

O'Niel, D. 1048

Oblas, D. W. 414

Occhionero, A. J. 381,445

Ohr, S. Y. 112

Ohriner, E. K. 276

Oliver, B. F. 670

Oliver, W. C. .. 432, 461, 635, 652, 672, 849

Olszewski, M.

Omatete, 0.0

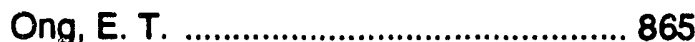

Commen, T. V. ......................................... 749

Ossandon, J. G. .............................839, 844

Ostry, M. E. ............................945, 959, 998

Otto, R. G. ............................................1090

Otvos, J. W. .............................................. 993

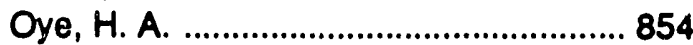

\section{$\mathbf{p}$}

Pace, M. O. ................................................ 766

Padgett, R. A. ....................................855-57

Paille, N. I. ............................................ 354

Palumbo, J. H. ........................................ 547

Park, E. ............................................. 374

Park, J. E. ......................................... 257

Parker, D. ............................................. 267

Parrish, D. J. ..................921, 942, 973, 974

Pasto, A. E. ...................................348, 421

Patten, D. O. ......................................... 453

Patterson, M. R. ....................137, 167, 610

Patton, J. B. .......... 752, 761, 777, 778, 783

Paulson, T. E. ..............................368, 393

Pawel, J. E. ........... 396, 397, 475, 494, 495

Peach, H. G. ............................................. 87

Pearman, N. .............................................. 275

Pedersen, C. R. ....................................... 195

Pelletier, P. J. .................................354, 372

Pennsylvania State University ...............583

Perez-Blanco, H. ... 126, 137, 167, 170, 610

Perlack, R. D. .............888, 901, 1030, 1047

Peters, J. S. ................................................ 15

Petersen, S. R. .................................... 242

Peterson, C. L. .......................................... 981

Petri, R. .............................................. 865

Petrich, C. H. .........................................1086

Petrie, T. W. ....................................195, 251

Pettifor, D. G. ........................................... 671

Petty, D, G. ............................................. 914

Pteifer, R. A. ............................................ 936

Pflanz, H. M. ....................................... 811

Phadke, A. G .............................. 767, 815

Phillips, B. A. .................................124, 129

Phillips, D. R. ........................................... 1039

Pierce, R. S. ............................................1012

Pih, H. ................................................ 464

Pimentel, D. ..........................................1029

Pinski, F. J. .................................646, 651

Plastics Institute of America ...........697, 698

Poche, J. M. ......................................... 339

Poirier, C. ................................................. 876 
Pollinger, J. P. $353,365,367,448$

Pompe, R. 439

Pope, P. E. 1014,1045

Poiter, W. D. 834

Post, W. M. 972

Povirk, G. L. ............................................... 670

Powell, R. H., Jr. ....................................... 191

Power, M. ............................................. 294

Pratt, D. C. .................................. 990, 1002

Preckel, P. ...............................................9935

Predmesky, R. L. .................. 410, 420, 463

Preece, J. E. ......................... 897, 903, 922

Pregitzer, K. S. .......................................... 896

Prindle, B. .............................................. 30

Privon, G. T. ......................................... 185

Prouse, D. W. ......................................... 473

Prowler, D. ...................................... 98, 284

Pruchnic, S. J., Jr. ................................ 497

Pujari, V. K. ... 354, 373, 392, 422, 443, 444

Purucker, S. L. 83,89

Quinn, G. D. 394,408

Quinn, T.F. J. 727

\section{$\mathbf{R}$}

Raab, J. 7,13

Racklitfe, G. B. 760

Radwan, M. A. 1008

Ragins, B. R.

Railsback, S. F. 86

Ranney, J. W. 887, 888, 895, 901, 923, 924 , $953,967,992,1005,1023,1046,1047$

Rao, G. R. 634

Rasmussen, R. W. 252

Rauscher, H. M.

Raymer, P. L.

Rayner, S. 950,952

Reardon, B. J. $904,905,926,943$

Rebenne, H. E

Reddy, C. S. $832,833,840$

Reddy, K. V. $381,445,479$

Reed, D. A.

Reed, J. H.

Reid, E. A.

Reiner, R. H. 543 1031 775

Resetar, T. M.

Rettberg, W. A 602 439 339
Reyes, I. 1036,1037

Rice, C. K

Riecke, G. T. $109,131,159,173,190$

Riekerk, $H$. 125

Rietveld, W. J. 1021

Rinehart, B. N. 1028

Rink, K. K. 577

Ritchie, R. H. 799,820

Ritschard, R. L. ....................................... 329

Rizy, C. G. ............................................. 906

Rizy, D. T. $740,747,752,761$, $777,778,783,794,807,822$

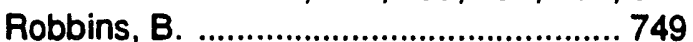

Robinson, D. A. ................................... 308

Rockefeller, G. D. ................................. 768

Rockenfeller, U. .......................... 861, 870

Rockwood, D. L. ..................996, 1031, 1049

Rogers, E. T. 157

Roke, L. 114

Romana, L. J. 396,397

Ronnberg-Wastljung, A. ......................... 945

Rose, P. A. 980

Rose, P. H. 339

Rosenfield, A. R. $374,488,513$

Ross, D. E.

Rossi, G. A.

$372,373,380$

Roth, P.I.

Roth, P. L. $382,422,443,453,455,470$

Roux, J. A 897,922

Rubinstein, $M$.

Ruggles, M. B. 271

Rule, L. 907, 620

Russell, M. 908

Rust, W. W. 901

Ryan, T. W., III 200 $559,569,576$

\section{$\mathbf{S}$}

Sabo, C. 12,18

Sakai, M 514

Salama, $K$ 830

Salas, T. M

Sale, M. J.

Sales, B. C. 743

Sales, L. C.

Salk, M. S.

Salomone L.......................................1025

Salyer, I.

Sand, J. R
354,392 256 875

$1084-87,1089,1090$

56 $105,110,118$
$147,148,158$ 
Sanders, J. P. 270

Sands, S. H. 769

Sankar, J. $359,451,481$

Santana, E. A. 872

Santavicca, D. A.

Santella, M. L. $391,468,490$ $633,674,678,687$

Santini, D. J.

Sarin, V. K. $381,445,479$

Sauers, I.

Saunders, H. E.

Saxonis, W.

Scarascia-Mugnozza, G.

Scarbrough, J. O.

Schaefer, G. E.

Scheid, H.W.

Scheithauer, R.

Scherr, M. I.

Schienle, J. .... 379, 441, 476, 482, 502, 516

Schlegel, J. A.

Schneider, T. R.

332,333

Schoch, K. F., Jr. 653

Schon, $A$. 749

Schubert, T. H.

Schulte, P. J.

Schultz, D. $776,800-804,818,819$ 749 15 978

Schweitzer, M.

Scofield, M. P.

Scott, C. D. 964,979 978,1027 907,908 $6,7,13,23$ $25,35,42,47,66,86,290$ $1053,1054,1056$ $1058,1060,1062-68,1077$

Scott, T. 272

Scott, T. C. 1053

Scull, $N$. 585

Sederott, R. R 966

Sefer, N. R.

Sekula, S. T. $548,558,569,574$

Sellmer, J. C. 852

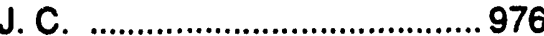

Selvamanickam, V. ............................... 830

Selverian, J. H. ............................. 395, 414

Sennerby-Forsse, L. ................................ 962

Sepulveda, J. L. ........................................388

Sernyk, J. L. .............................................. 905

Seybold, K. G. ............................................ 356

Shaakir-Ali, J. A. ..................................... 1086

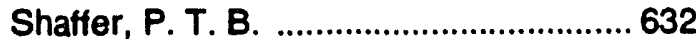

Shapiro, A. 716

Sharp, T. R. $234,302,304$

Shaw, J. H. 751,781

Shelton, W. A 646

Shelton, W. A., Jr. 651
Shen, L.

267,308

Sheppard, K. ....................................... 260

Sherman, M. H. ..................................... 329

Shetty, D. K. ..................................473, 518

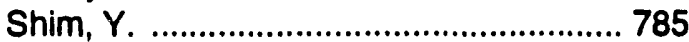

Shipp, P. H. .........................251, 268, 270

Shirley, S. T. ......................................... 277

Shonder, J. A. .......................................... 116

Shonka, D. B. ..........................................54

Siebein, K. N. .......................373, 422, 443

Sikka, V. K. ...................658, 665, 683, 696

Silver, M. N. ...................................757, 770

Simpson, W. A. ......................456, 467, 478

Simpson, W. A., Jr. .........................663, 691

Sinha, A. ................................................. 451

Sircar, A. ................................................ 874

Sisson, W. G. ..................... 1073-75, 1077

Sivers, E. A. ......................................... 365

Skadberg, A. .................................907, 908

Skrurud, C. L. ........................................... 993

Sladden, S. E. .......................941, 968, 980

Sluiter, M. ................................................ 646

Smidt, F. .............................................. 720

Smith, B. .............................................. 978

Smith, C. T. .............................................. 1021

Smith, D. .............................................1016

Smith, I. D. ................................................. 814

Smith, J. D. B. ........................................ 749

Smith, J. L., Jr. ........................................ 182

Smith, S. A. .............................................44

Smith, T. L. ............................................. 202

Smyth, J. ...............................................5 502

Snell, S. A. ...............68, 72, 736, 737, 738

Snoha, D. J. ......................................... 408

Soderstrom, E. J. .................................. 738

Solidum, E. .........................353, 367, 379

Solomon, A. D. ..............................871, 874

Sols, F. .......................................799, 820

Sommers, G. L. ..................................1084

Sparks, C. J. .............................642, 854

Specht, E. D. ..............................852, 854

Spooner, S. ........................................... 591

Srinivasan, G. V. ................................... 370

St. Julien, D. .......................................... 661

Stansbury, E. E. .....................205, 206, 232

Stanton, B. J. ........................................1007

Star, E. C ................................................ 812

Star, T. L. ................................................. 637

Statt, T. G ................................................ 147

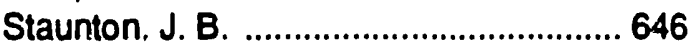

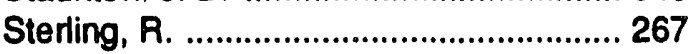

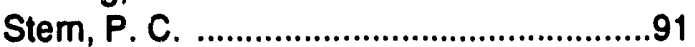


Stettler, R. F.

Stevens, R. A. $890,898,949,978,1007$

Stewart, J. R: 798

Stewart, W. E., Jr. 787,792

Stickler, L. A.

Stiel, L. I.

Stiles, E. D. 869,873

.....873

Stimely, G. L.

Stinton, D. P.

Stocks, G. M.

Stoecker, W. F.

Stolof, N. S.

Stone, J. W.

Stone, T. A.

Storm, R. S.

Stovall, J. P.

Stovall, T. K.

Stover, L. R.

Strand, R. F.

Stranford, G.

Strauss, C. H.

$925,954,960$,

Strehlow, R. A

$961,1000,1019,1020$

Stucky, D

401

Suelzle, L. R.

Sugihara, G. 791

Sullivan, R. 1048

Sullivan, $\mathbf{R}$. 113

Sullivan, R. L

282,283

Sullivan, T. M. 812

Sumner, D. R. 369

Sundberg, G. J.

Surles, S. E.

Swab, J. J.

Swain, M. N.

Swain, M. R.

Swain, M. V.

Swank, W. T.

Swanson, R. E.

Swartz, S. L.

Swedish Motor Fuel Technology Co.

Swihart, J. C.

$838,839,841,844,845,847$ $373,380,422,453$ 975 $408,429,430,459,507$ 545,572 545,572 .. 510 1012,1021 .. 450 374,454 . .562 636

\section{$\mathbf{T}$}

Takeyama, M. 645

Tang, $z$. 900

Taub, A. I. 664

Taylor, E. R., Jr. 747,750

Taylor, M. J. 871,882
Taylor, S. E. ....................................... 993

Ten Eyck, M. O. ................................. 347

Teng, K. ........................................... 482

Tennery, V. J. .......................398, 425, 427

TenWolde, A. ................................... 262

Ternes, M. P. .................... 296, 302-305, $313,314,319,325,327,330,341$

Tesche, F. M. ................. 742, 747, 758, $762,769,772,779,789,797,808$

Tew, T. 1039

Tewari, P. H. 444

Thacker, L. S. 193

Thoma, P. ......................................... 642

Thomas, D. E. .................................. 743

Thomas, D. L. ............................. 926, 943

Thomas, J. R., Jr. .............................. 269

Thompson, J.C. ................................ 773

Thompson, J. E. .........................1059, 1062

Thompson, J.R. ................ 825, 827, 838,

$839,841,844-48,852$

Thomson, E. M. ...................788, 793, 805

Thomson, J. O. ................................. 838

Thornbur, R. W. ................................. 920

Thorp, J. S. ............................... 767, 815

Thrill, D. C. .............................. 904, 905

Tiegs, T. N. ... 419, 431, 433, 434, 465, 489, $493,500,504,505,512,523,618,670$

Ting, B.-Y. $712,713,726$

Tinus, R. W.

Tkaczyk, J. E.

Todd, D. E.

$660,661,828$

Tomlinson, J. J.

$927,1011,1042$ $859,864,866$,

$868,871,879,882$

Tonn, B. E. 85,89

Torpey, M. R.

Torreano, S. J.

Tortorelli, P. F. 258

Tracey, D. M.

Triolo, $R$. 662

Tritton, L. M. 354

Trumble, D. A.

Tschaplinski, T. J.

Tucker, W. T

Tuluca, A. N.

Turchi, P. E. A.

Turhollow, A. F

Turner, R. H. $944,953,971,994,999,1024$

Tuskan, G. A.

Tye, R. P.

887,930

222, 230, 274 
$\mathbf{U}$

Uman, M. A. $745,755,764$, $788,793,795,805$

Unban, C. M. 565

\section{V}

Vaccari, D. L. 355,440

Vahlas, C. .837

Vaidyanathan, $R$ 359,481

Valore, R., Jr. 261

Van Geem, M. G.

Van Lear, D. H.

Van Miegroet, $\mathrm{H}$.

Van Volkenburg, $E$.

Vance, E. F.

Vance, M. C.

Vaughan, D. H.

Venezia, A. M.

Venkateswaran, V.

Veverka, E. F.

Vincent, R. J.

Vineyard, E. A.

A. ..

Vineyard, T. A

Vinyard, $S$.

Violette, D. M.

Virkar, A. V.

Voldrich, $W$.

Volenec, J. J.

Vonier, $T$.

Vories, R.

Voshall, R. E.

Voss, M. K.

Votaw, P. C.

$253,259,277,281$

1012,1021

1012

978

742,795

623,631

$921,942,974$

657

437

$751,806,814$ 138

$107,114,117,119$,

$120,127,147,148,171$

344

569

15

473,518

384

939,1003

230

288

749

196

803,804

\section{W}

Waddle, D. B. 765

Wade, J. A. 380

Wade, J. C. 356

Wadsworth, J. 688

Wagner, C. L. 739,768

Wahiduzzaman, $\mathrm{S}$.

Wakenell, J. F.

Waldman, D. J.

Waldron, W. D.

Walliorf, S. P.

Walling, R. A.
Wang, J. S. 392

Wang, J. T.

Wang, Z. L. 1081

Wang, Z. L. 634

Wantland, J. L. ...............................570, 580

Ward, C. Y.

980

Ward, T. L. ................................................. 829

Wamer-Selph, M. A. ............................... 569

Warren, J. W. ........................................ 639

Warwick, W. H. ..................................... 431

Wasserman, D. M. ................................ 323

Watson, M. A. ........................................... 388

Watts, J. A. ..........................................1086

Watts, R. L. ..............................................44

Weaver, F. J. .......................207, 208, 215,

$220,224,228,491,650$

Weaver, R. S. ......................................... 229

Webb, J. W. ............................................ 1086

Weil, R. ............................................... 260

Weiss, C. D. ................................417, 447

Weiss, P. .................................................53

Wenzel, C. R. .........................................1023

Wereszczak, A. A. ....................................1093

Werst, S. H. .......................................... 220

Wert, J. J. ......................................396, 397

West, B. H. .......................412, 527, 529,

$531,533,534,551,552$

West, D. C.

Westmoreland, C. G. 1021

Wetherington, G. R.

615,641

Whalen, $P$.

353,367

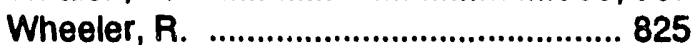

Wheeler, R. B.

Whitaker, R. A.

$759,785,817$

White, D. L.

$14,30,55,80,83$,

$85,95,288,299,301,344$

White, K. W.

514,515

Whitenton, E.P.

Whitesell, C. D.

$.715,716$

Wiard, B. M.

$964,979,1026$

Wiederhorn S.M.

Wiesman, C.

Wiggins, C. M. ............................ 743

Wilbanks, T. J. ..............................................91

Wilcox, B. A. ....................................... 216

Wilkes, K. E. ................195, 197, 201, 236, $270,304,310-12,315,318,331,337$

Williams, $F$. 1081

Williams, L. S. .................. 21, 38, 57, 61, 70

Williams, L. S. .................................... 313

Williams, R. K. .......433, 477, 491, 505, 843, $849,850,851,855,857,858$ 
Williams, V. 339

Willkens, C. A. $354,373,443,471,483$

Willman, A. J.

Wilson, B. C.

Wilsun, C. $\mathrm{A}$

Wilson, D. F.

Wilson, L. F.

Winer, W. 0 .

Winsor, R. E.

Wintenberg, A. L.

Witherspoon, M. J.

Wittmer, D. E.

Wolf, D. D.

Wolf, J. D.

Wolf, J. S.

Wolf, S. M.

Wolfe, A. K. 5 ,

Wong, P. S.

Wong, V. W.

Woodfin, S. L.

Wr tward, J. A.

Worrnington, T. K.

Wray, P.

Wright, J.

Wright, L. L. ....887-89, 911, 924, 925, 931 $932,937,953,955,961,967,969,985$, $988,992,1004,1005,1023,1046,1050$

Wright, $N$.

Wright, $T$.

Wu, F. J.

Wyman, C. E. 934 299 380,453

339

$729,730,732$

598,707

998

$712,726,727$

538

766

368,393

$921,942,973$

409,413

605

653

.. 86

1062

$825,841,846-48$

907,908

1032

917,951

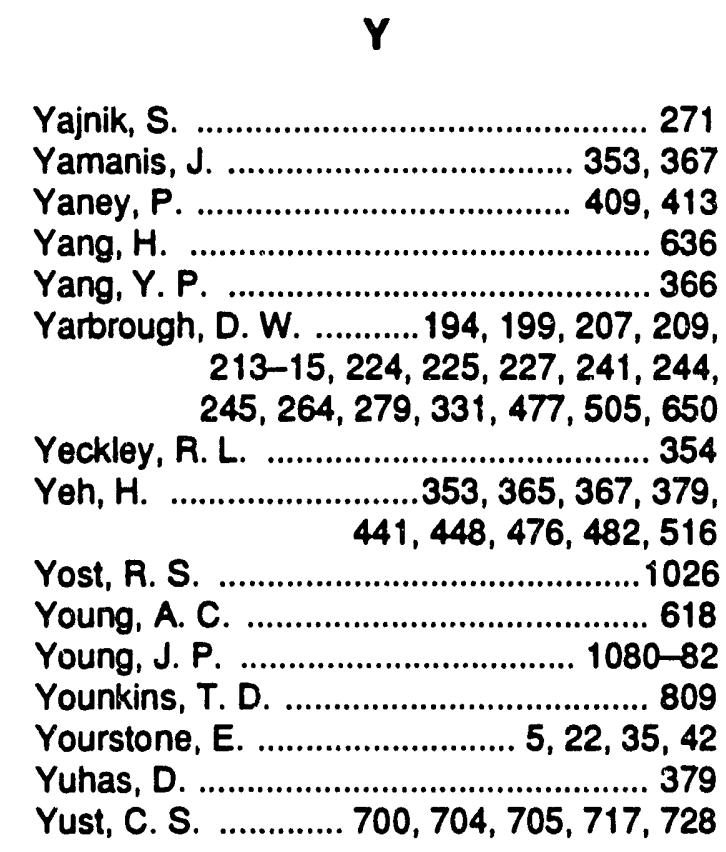

2

Zaltash, A. $600-604$

Zarr, R. R. 209

Zawacki, T. S $144,160,179$

Zerega, A. M.

. .72

Zhu, S. 827

Zilberstein, G.

Zimmerman, K. H. $442,469,484,508$

Zinkle, S. J.

\section{7}

413

366
09, 
Internal Distribution

\begin{tabular}{|c|}
\hline $\begin{array}{l}\text { D. Adams } \\
\text { L. J. Allison } \\
\text { S. W. Allison } \\
\text { R. J. Andermann, Jr. } \\
\text { P. Angelini } \\
\text { L. D. Armstrong } \\
\text { D. C. Bauer } \\
\text { O. A. Basaran } \\
\text { V. D. Baxter } \\
\text { J. J. Blass } \\
\text { P. J. Blau } \\
\text { A. Bleier } \\
\text { M. D. Boring } \\
\text { C. R. Boston } \\
\text { R. A. Bradley } \\
\text { C. H. Brown } \\
\text { M. A. Brown } \\
\text { R. A. Buhl } \\
\text { R. S. Carlsmith } \\
\text { C. P. Chihasz } \\
\text { A. Choudhury } \\
\text { J. E. Christian } \\
\text { S. M. Cohn } \\
\text { J. L. Cook } \\
\text { J. W. Cooke } \\
\text { D. Copinger } \\
\text { J. M. Corum } \\
\text { J. M. Cosgrove } \\
\text { G. E. Courville } \\
\text { J. Coyner } \\
\text { B. L. Cox } \\
\text { D. F. Craig } \\
\text { F. A. Creswick } \\
\text { J. H. Cushman } \\
\text { B. H. Davison } \\
\text { A. O. Desjarlais } \\
\text { J. Dickerman } \\
\text { N. Domingo } \\
\text { R. E. Eversole } \\
\text { P. D. Fairchild } \\
\text { T. D. Ferguson } \\
\text { J. J. Ferrada } \\
\text { S. K. Fischer } \\
\text { S. }\end{array}$ \\
\hline
\end{tabular}

44. C. Forsberg

45. W. Fulkerson

46. R. L. Graves

47. T. Grizzard

48. C. A. Gunderson

49. R. M. Harrington

50. M. R. Harris

51. R. A. Hawsey

52. S. G. Hildebrand

53. L. J. Hill

54. E. Hillsman

55. D. R. Hines

56. P. J. Hughes

57. P. J. Hughes

58. M. G. Jenkins

59. R. L. Jolley

60. L. Jung

61. M. A. Karnitz

62. M. J. Kass

63. E. N. Kaufman

64. S. B. Kennedy

65. H. T. Kerr

66. T. Klasson

67. J. O. Kolb

68. R. P. Krishnan

69. M. A. Kuliasha

70. E. H. Lee

71. N. E. Le日

72. W. Y. Lee

73. K. C. Liu

74. R. A. Lorenz

75. P. M. Love

76. G. M. Ludtka

77. G. Mackiewicz-Ludtka

78. J. C. Mailen

79. G. Marland

80. W. R. Martin

81. J. R. Mayotte

82. E. W. McDaniel

83. R. N. McGill

84. H. A. McLain

85. R. McMahon

86. W. R. Miartin 


\begin{tabular}{llll}
87. & V. C. Mei & 122. & W. D. Siemens \\
88. & G. E. Michaels & 123. & P. S. Sklad \\
89. & S. Michaud & 124. & E. J. Soderstrom \\
90. & W. R. Mixon & 125. & B. M. Sorensen \\
91. & J. J. Morello & 126. & A. Sozer \\
92. & M. T. Naney & 127. & G. W. Strandberg \\
93. & R. J. Norby & 128. & V. J. Tennery \\
94. & R. E. Norris & 129. & P. T. Thornton \\
95. & S. D. Nunn & 130. & V. R. Tolbert \\
96. & D. G. O'Connor & 131. & J. J. Tomlinson \\
97. & C. E. Oliver & 132. & C. Trettin \\
98. & L. J. Ott & $133-82$. K. H. Vaughan \\
99. & J. T. Parks & 183. & C. D. Warren \\
100. & A. Pasto & 184. & D. A. Waters \\
101. & R. D. Perlack & 185. & J. A. Watts \\
102. & M. J. Peterson & 186. & J. R. Weir \\
103. & L. P. Phillips & 187. & A. Wereszczak \\
104. & D. D. Rhew & 188. & D. L. White \\
$105-109$. & C. K. Rice & 189. & J. Whitefield \\
110. & D. T. Rizy & 190. & T. J. Wilbanks \\
111. & G. L. Riner & 191. & K. A. Williams \\
112. & P. A. Rubin & 192. & G. M. Wood \\
113. & M. J. Sale & 193. & H. D. Wooten \\
114. & R. Sams & 194. & S. B. Wright \\
115. & R. Sanders & 195. & R. E. Ziegler \\
116. & A. C. Schaffhauser & $196-97$. Laboratory Records \\
117. & E. Schorn & 198. & Laboratory Records-RC \\
118. & W. E. Schramm & 199. & ORNL Patent Office \\
119. & R. E. Schreiber & 200. & Central Research Library \\
120. & R. N. Scogin & 201. & Document Reference Sect. \\
121. & T. C. Scott & & \\
\hline & & &
\end{tabular}

\section{External Distribution}

202. Henry Amistadi, RR 2, Box 2191C, Brunswick ME 04011

203. John Andre, NRECA, Norris Memorial Library, 1800 Massachusetts Avenue, NW, Washington DC 20036

204. Stuart Baird, ICLEI, 8th Floor, East Tower, City Hall, 100 Queen Street West, Toronto, Ontario M5H 2N2

205. David Barraco, LightStat, 15 Canton Spring Road, Canton CT 06019

206. Jerry Bellucci, Applied Economics Research, 299 Broadway, Suite 803, New York NY 10007 
207. Belinda Chan, Gas Marketing Department, Consolidated Edison, Four Irving Place, Room 305, New York NY 10003

208. Howard Geller, Executive Director, American Council for an EnergyEfficient Economy, Suite 801, 1001 Connecticut Avenue, NW, Washington, D. C. 20036

209. Thomas J. Gross, Deputy Assistant Secretary for Transportation Technologies, EE-30, FORS, U.S. Department of Energy, 1000 Independence Avenue, SW, Washington DC 20585

210. Donna Hawkins, Office of Building Technologies, EE-40, FORS, U.S. Department of Energy, 1000 Independence Avenue, SW, Washington DC 20585

211. Ann Hegnauer, Office of Transportation Technologies, EE-30, FORS, U.S. Department of Energy, 1000 Independence Avenue, SW, Washington DC 20585

212. Richard Hirsh, Department of History, VPISU, Blacksburg VA 240610117

213-214. B. Kavanaugh, Center for Energy Studies, Louisiana State University, Baton Rouge LA 70803-0301

215. Peter O'Farrell, Oakhurst Associates, 26 Rockmont Road, Arlington MA 02174

216. Mark Levine, Applied Science Division, Lawrence Berkeley Laboratory, Building 90-4000, One Cyclotron Road, Berkeley CA 94720

217. John P. Millhone, Deputy Assistant Secretary for Building Technologies, EE-40, FORS, U.S. Department of Energy, 1000 Independence Avenue, SW, Washington DC 20585

218. Ms. Marsha L. Quinn, Office of Industrial Technologies, Energy Efficiency and Renewable Energy, U.S. Department of Energy, 1000 Independence Avenue, SW, Washington DC 20585

219. Arthur H. Rosenfeld, Center for Building Science, Building 90-3085, Lawrence Berkeley Laboratory, Berkeley CA 94720

220. T. V. Ramachandra, Centre for Ecological Sciences, Indian Institute of Science, Bangalore, 560012 India

221. Mary Rouleau, AARP State Legislative Department, Utility Issues, 601 E Street, NW, Washngton DC 20049 
222. Tish Russell, 2222 222nd Street SE, Bothell WA 98021

223-26. Don Sample, USDOE, OSTI, P. O. Box 62, Oak Ridge TN 378319939

227. Dr. R. L. San Martin, Deputy Assistant Secretary for Utility Technologies, EE-10, FORS, U.S. Department of Energy, 1000 Independence Avenue, SW, Washington DC 20585

228. Ms. Cathy Short, Office of Utility Technologies, EE-10, FORS, U.S. Department of Energy, 1000 Independence Avenue, SW, Washington DC 20585

229. Judy Spinner, Kansas City Power \& Light Company, Department of Regulatory Affairs, 1201 Walnut, 20th Floor, Kansas City MO 64106

230. Frank M. Stewart, Jr., Deputy Assistant Secretary for Technical and Financial Assistance, EE-50, FORS, 1000 Independence Avenue, SW, Washington DC 20585

231. Andrew Stirling, Energy Group, Science Policy Research Unit, Mantell Building, University of Sussex, Falmer, East Sussex

232. Alan J. Streb, Deputy Assistant Secretary for Industrial Technologies, EE-20, FORS, U.S. Department of Energy, 1000 Independence Avenue, SW, Washington DC 20585

233. Linda Testa, SRC, 111 Presidential Boulevard, Suite 127, Bala Cynwyd PA 19004

234. Pamela Torres, Electric Power Research Institute, Room 6-113, 3412 Hillview Avenue, Palo Alto CA 94303

235. Phillip Wemhoff, T-7, Jacksonville Electric Authority, 21 West Church Street, 7th Floor, Jacksonville FL 32202

236. Andrew Wynn, EC Division, SHS 130, Augusta ME 04333

237. Office of the Assistant Secretary for Energy Efficiency and Renewable Energy, EE-1, FORS, U.S. Department of Energy, 1000 Independence Avenue, SW, Washington DC 20585

238. Office of the Assistant Manager for Energy Research and Development, DOE/ORO, P. O. Box 2008, Oak Ridge TN 378316269

239-77. Office of Scientific and Technical Information, USDOE, P. O. Box 62, Oak Ridge TN 37831 

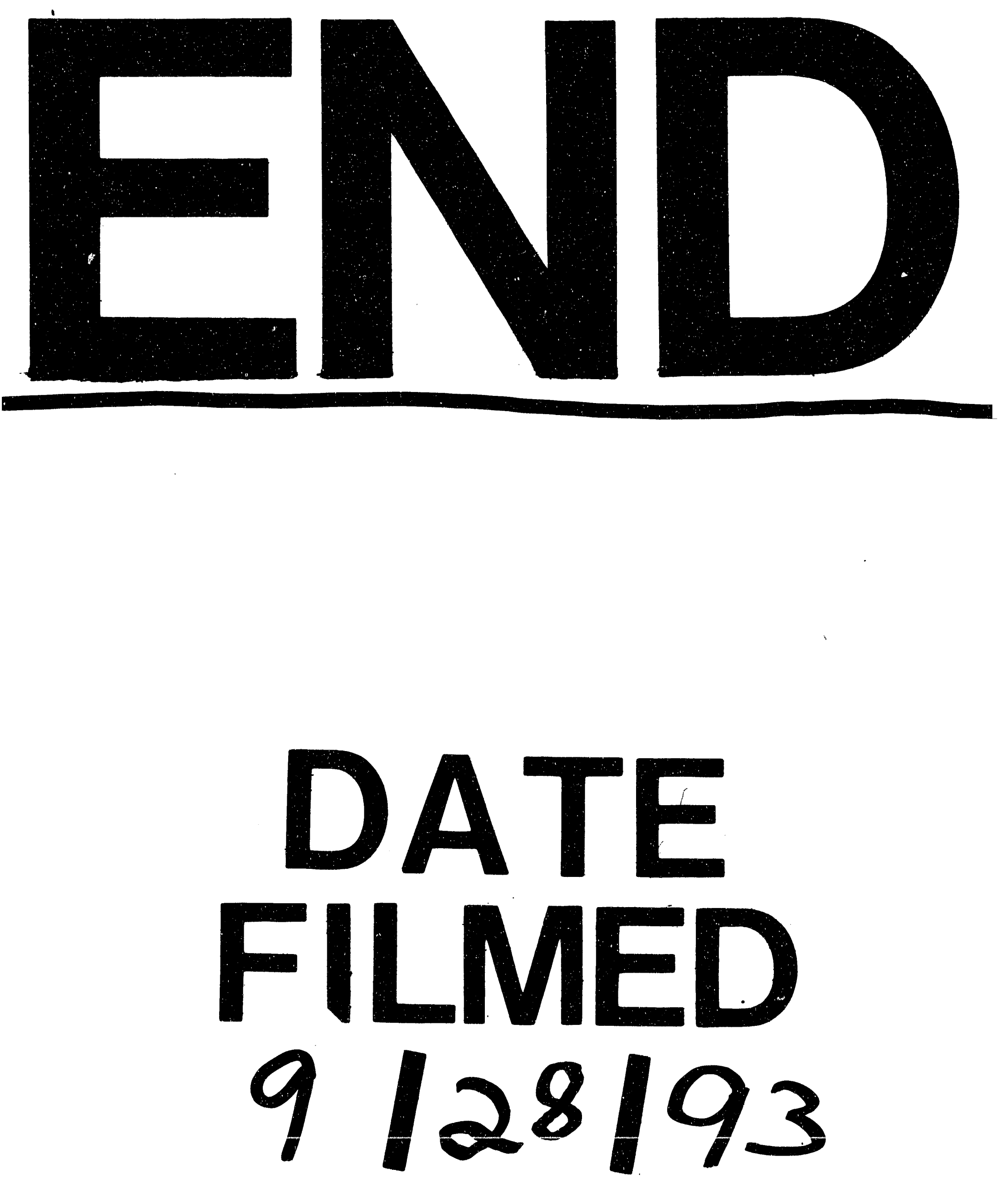
